\title{
ONWI-354
}

BMI/ONWI - 354

TI90 009083

\section{Archaeological Data as a Basis for Repository Marker Design}

\author{
Techaical Repoot
}

\section{October tre}

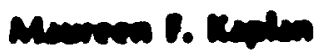
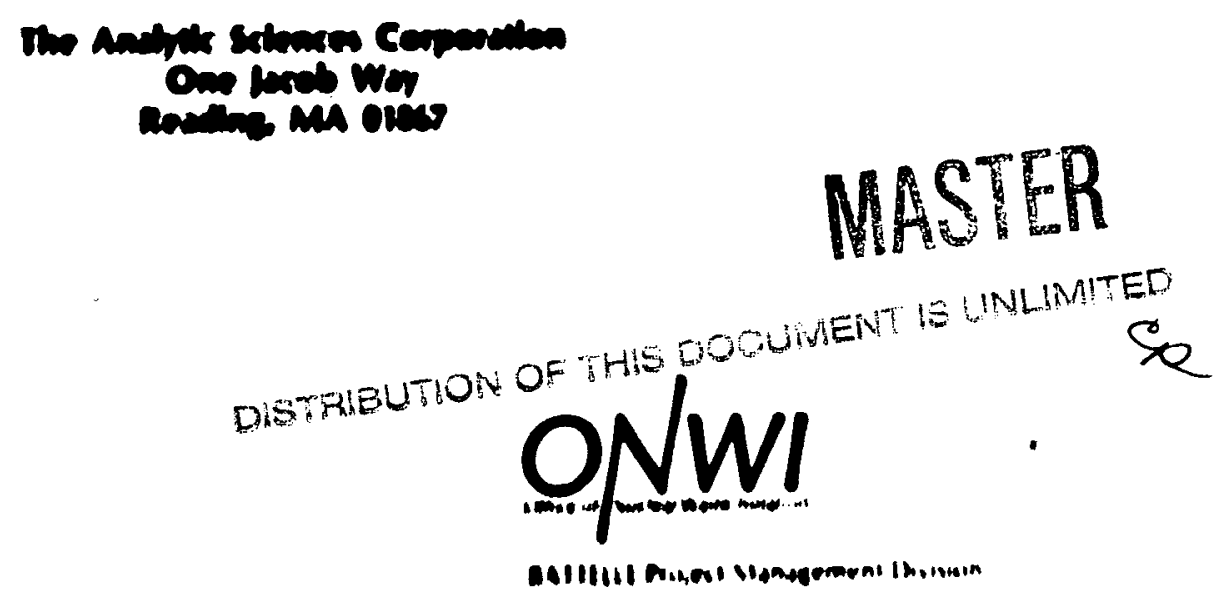

$10040 \quad 101$. 


\section{DISCLAIMER}

This report was prepared as an account of work sponsored by an agency of the United States Government. Neither the United States Government nor any agency Thereof, nor any of their employees, makes any warranty, express or implied, or assumes any legal liability or responsibility for the accuracy, completeness, or usefulness of any information, apparatus, product, or process disclosed, or represents that its use would not infringe privately owned rights. Reference herein to any specific commercial product, process, or service by trade name, trademark, manufacturer, or otherwise does not necessarily constitute or imply its endorsement, recommendation, or favoring by the United States Government or any agency thereof. The views and opinions of authors expressed herein do not necessarily state or reflect those of the United States Government or any agency thereof. 


\section{DISCLAIMER}

Portions of this document may be illegible in electronic image products. Images are produced from the best available original document. 


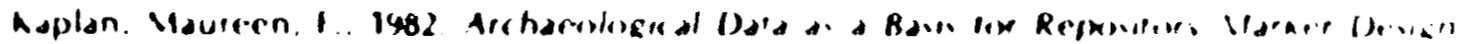

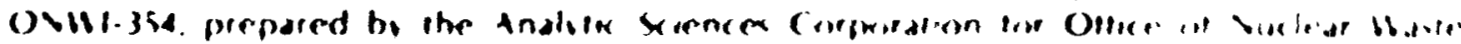

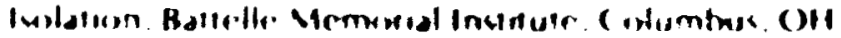

\section{notnct}

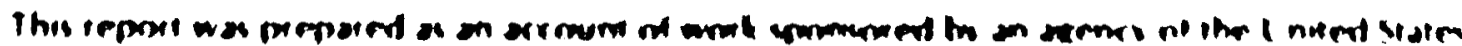

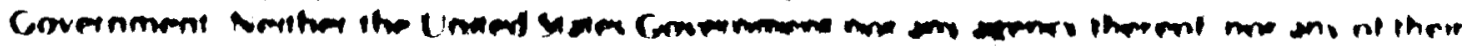

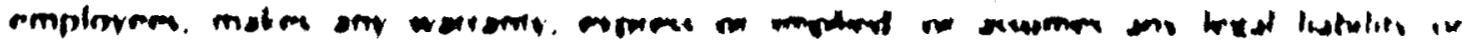

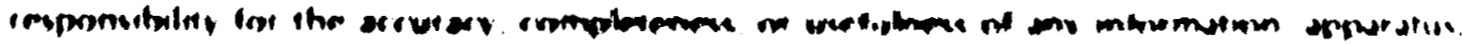

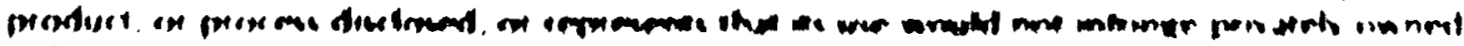

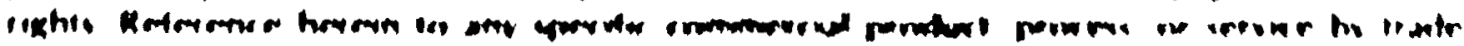

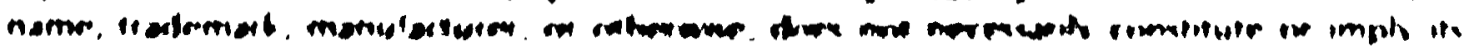

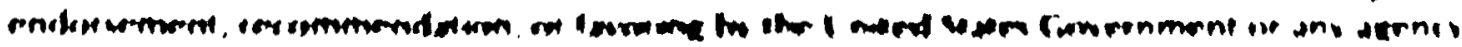

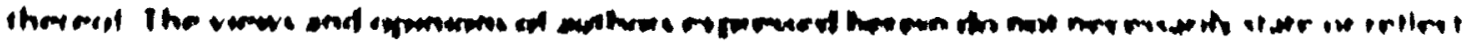

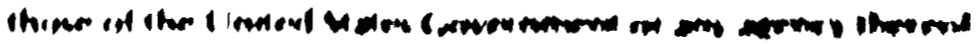

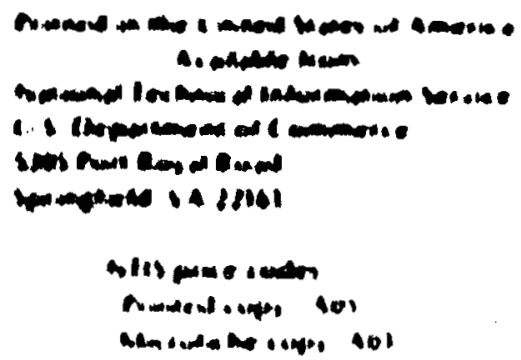




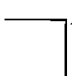
.
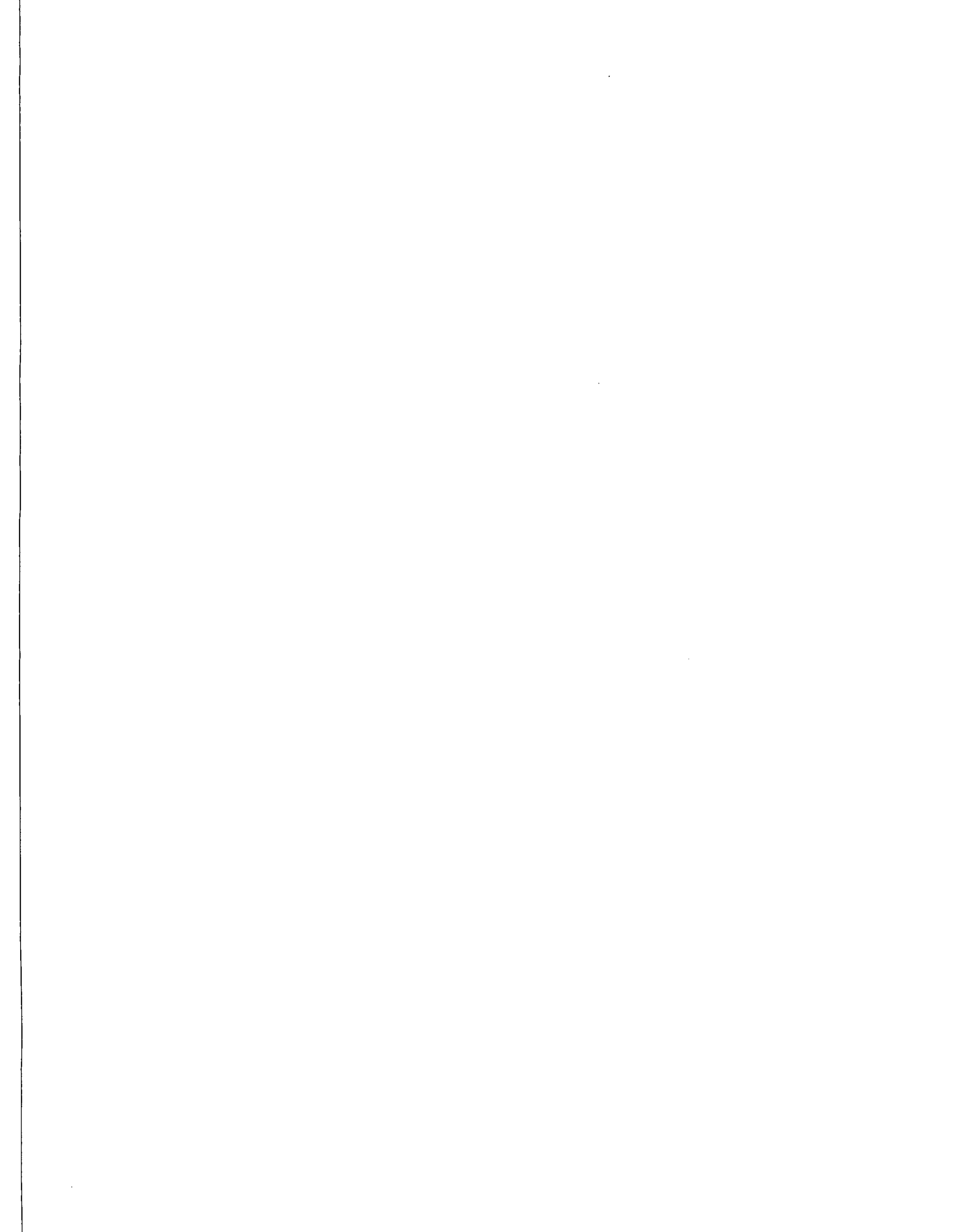
ONWI-354

Distribution Category UC-70

\title{
Archaeological Data as a Basis for Repository Marker Design
}

\author{
Terhnical Repon
}

\section{Orsober 1932}

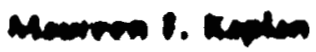

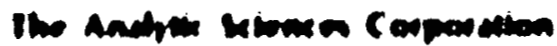 \\ com inch wos \\ aromine mat oress
}

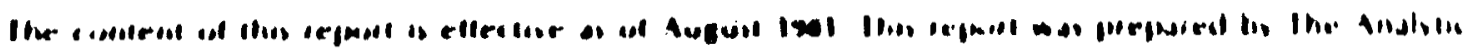

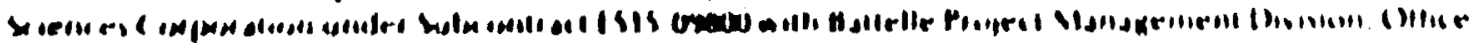

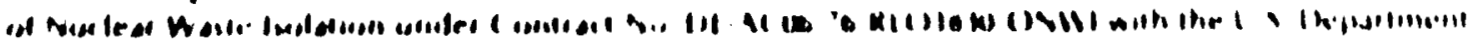

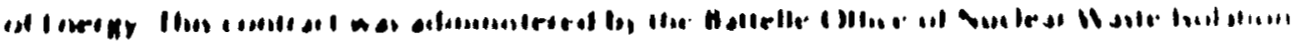

$$
800.181317
$$



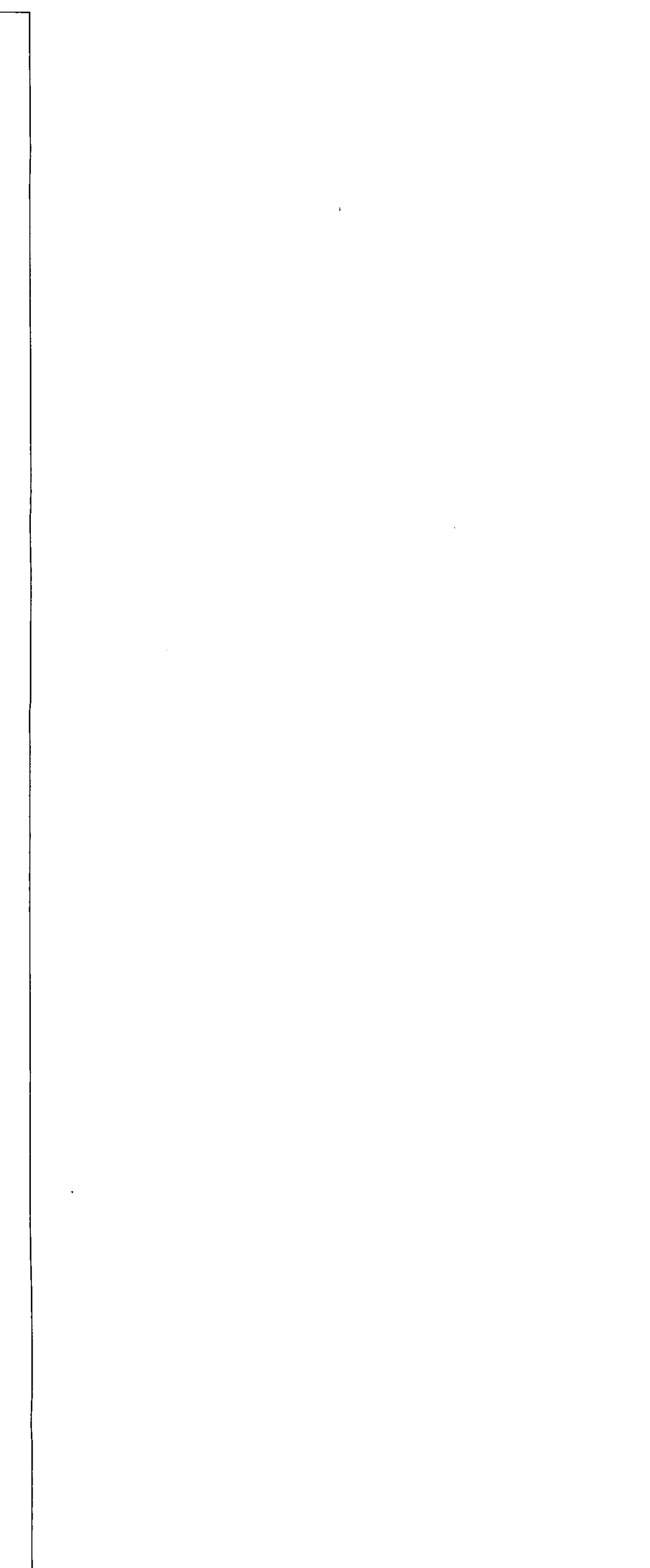
i i i

ABSTRACT

This report concerns the development of a asking system for a nuclear waste repository which is very likely li) survive for in, on n velars. In order to provide a backround on the subject, and for the prellatinary design pretrented in this report. A discussion is presented about the issues involved in human interference with the repository system and the comantcation of Information. A separate chapter summarizes stanclent manmade comments IncludeIng: materials, effects of associated textual Information on our understanding of the comment. and other features of the ancient ament relevant to anking repository ste. The infurastion presented It the two chapters is wed to provide the basis and rationale for ptellelacty marker system design presented In final chapter.

$800+1018$ 

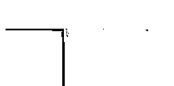


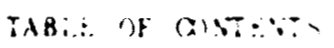

PAge

l INTRODICTIOS. . . . . . . . . . . . . . . . . .

2 HIYAT ITTERFERECF . . . . . . . . . . . . . . . . . 2.1 MTSSAGF EXISTENCE . . . . . . . . . . . . . . . . . 2.1 .1 Megsage Defintition................... 2.1.2 Moqatge incation. 2.1 .3 Mesange Survivabiaty . . . . . . . . . . . . .

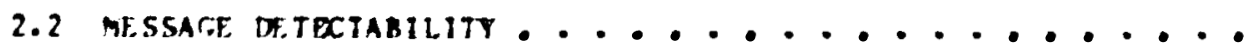
2.3 messace comprehensibility . . . . . . . . . . . . . 2.4 simmar . . . . . . . . . . . ............

3

3

ARCHAEOISX, ISA, MARKE, 3.1 SELECTto texampizs....................... 3.1 .1 pyrabian, terint 3.1 .2 sionchenes. Theinat 3.1 .1 Rare inoe. rory

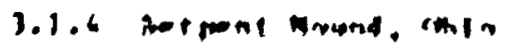
1.1.; Arenotite, cereare 1.1.h cater Wall, Ching

1.2 $01 \pi \mathrm{s}, \mathrm{sich}$

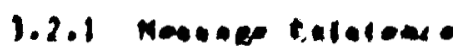

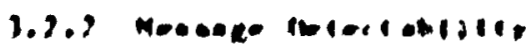

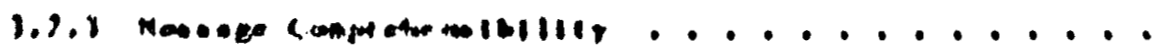

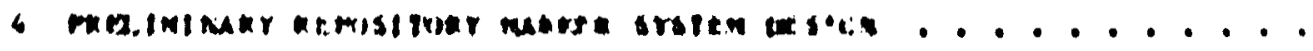

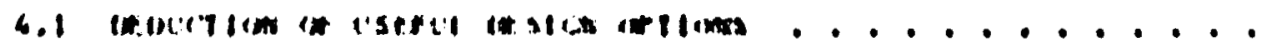
4.2 marse srotin testck . . . . . . . . . . . . . . .

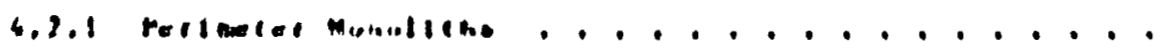
4.2.1 t.ectlonot. . . . . . . . . . . . . . . . .

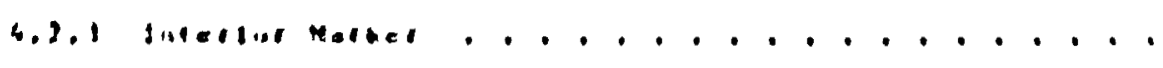

1

3

s

5

9

in

12

19

10

60

an

is

11

Id

in

$+1$

4

$+4$

49

II

(1)

(1)

14

54

$n !$

a 1

$800.0 \quad 1: 19$ 


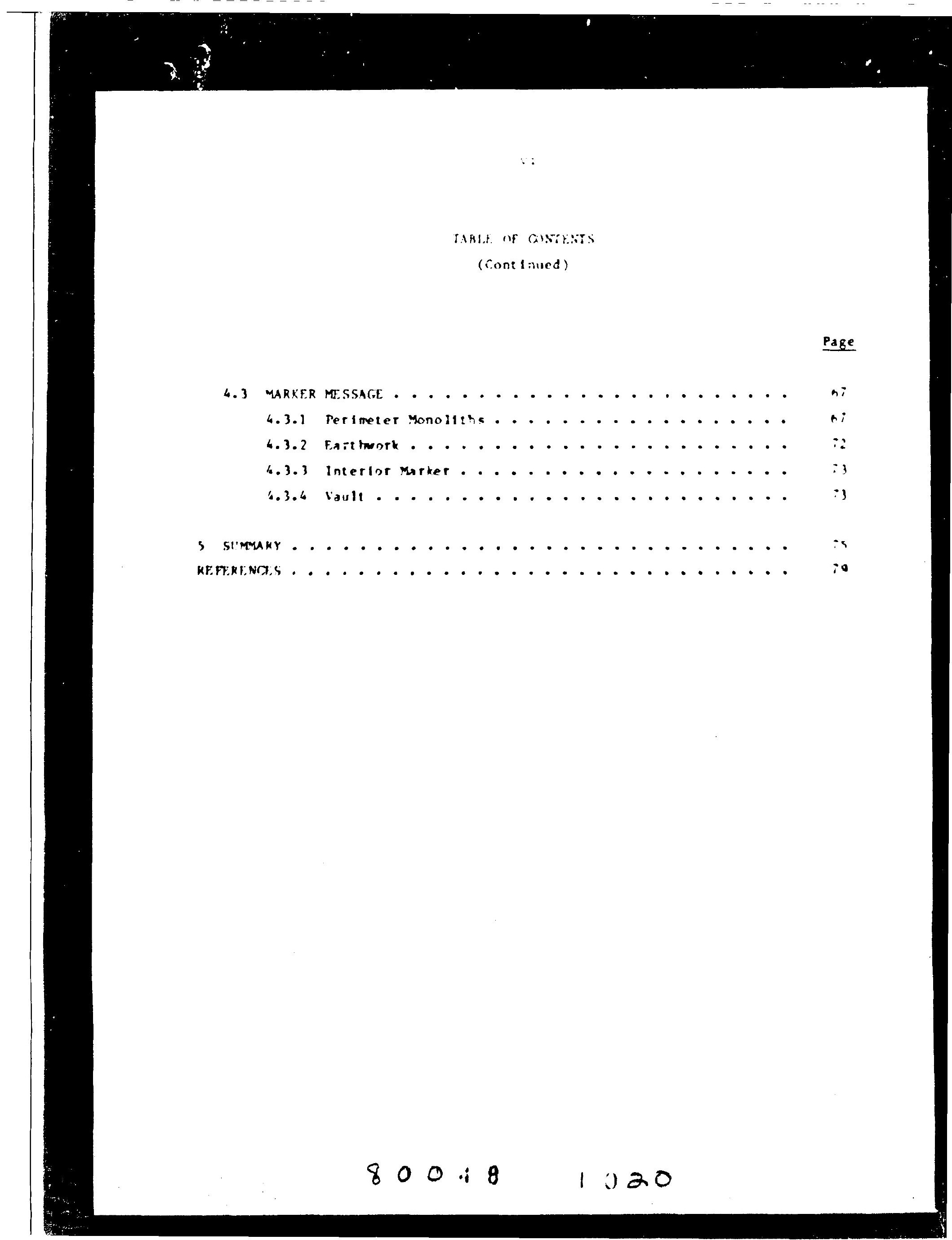

\section{$800: 8 \quad 1020$}


2-1 Maln loglc Digram for Warning Messages . . . . . . . . . -

2.1-1 Logle Diagram for Mesage Fxistence............. . .

2.2-1 Logle Dlagram for Message Detectablitty . . . . . . . . 10

2.3-1 Logic Chart for Message Cotprehensiblite . . . . . . . . It

2.3-2 Example Symbols Used with Atodc Materials . ........ . Is

2.3-3 Scene Frow Tomb of Djehutyhetep Transporting Statue to Shrine ........................ . 15

3.1-1 pyramids, Egypt . . . . . . . . . . . . . . . . . . . . 20

3.1-2 Inner Circles of Stonehenge, England . . . . . . . . . . 2h

3.1-3 Plan of Stonehenge, England . . . . . . . . . . . . . it

3.1-4 Serpent Mound .......................... 34

3.1-5 The Arropoll., Greece..................... 3

3.1-6 Plan of the Acropolla, Greece................. 39

3.1-7 The Great wall of China.................... 4s

3.1-8 A seguent of the Great Holl .................... is

4.1-1 lag1c DIagran Ior Vaefal opelons . . . . . . . . . . . . S4

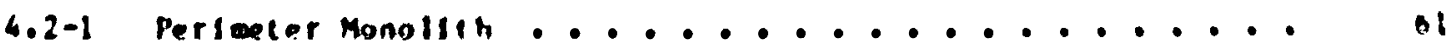

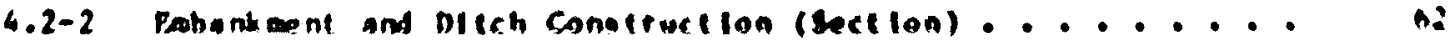

4.2-3 Section and Top View of Tumulue ond inceplor

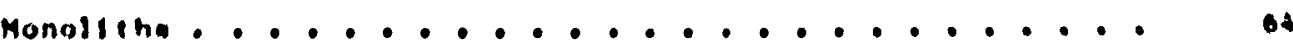

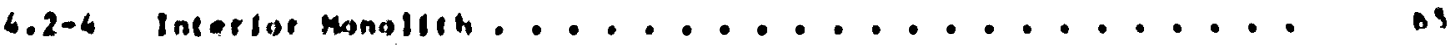

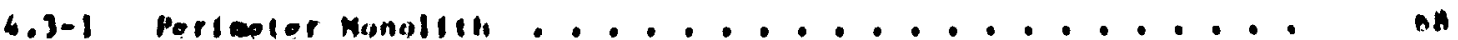

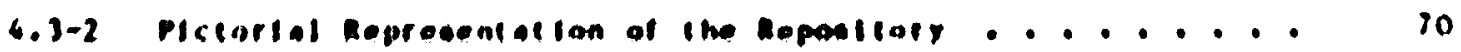

4.3-3 Intertar Munaltih...., ................... 12

I.IST IN IAgIt:S 


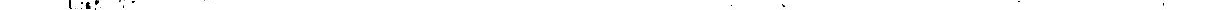


1 INTRODUCTION

The office of Nuclear haste Isolation (sill) has established the Human Interference Task Force (HITF) to respond to the issues of human interference activities in nuclear waste isolation. The purpose ot the HIT f is to develop an approach to reducing the likelihood of future human interference with the nuclear waste repository system. The HIT has focused on the development of effective, lorg-tera communication systems as being leportant for alnialzing the likehood of human interference. Thus, the HIT is concerned with communicating information about nuclear waste repository locations, contents. and associated risks, both at the repostito site itself and at numerous places away from the ste. The the it race of interest for the asking system is In,000 years after repository closure: this is consistent with draft Epa waste eansgevent crtteria.(1)

This report is written in support of, and is consistent with. the unit af the HITS. It primarily addresses the problem of anting the repository site

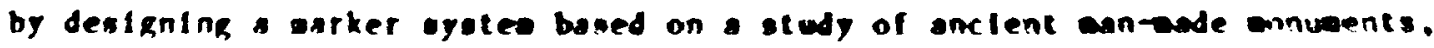
come of which have survived for up to 5,000 years. The carter system design entails both the physical acting of the ste ami the communication of Infincation about the ate by the amhara. In order to delineate the central pres el sen upon mich tho design 1. based. Chapter 2 presents a discursion of the

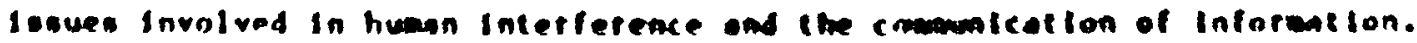

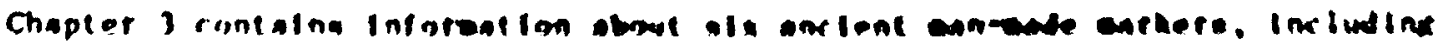

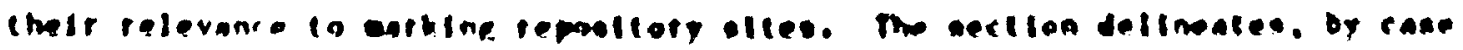

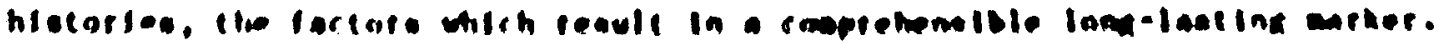

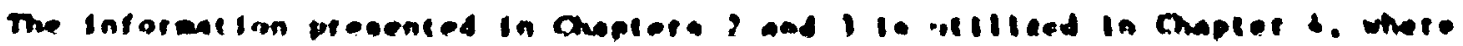

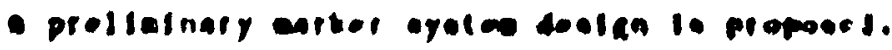

$80010 \quad 1022$ 
2 MYMAN INTERFEREST:

The safe disposal if hith-level radloactive waste is a subject of murh interest to the keneral public and the sotentifte communtey. Oile method of disposal calls fur the waste in be burled la a deep onined repositury with a series of bartiers between the waste and the environaent. These harrlers include, but are not limited to, transformation of the waste lato a lonklasting material. enclosure of thls saterial ia a durable cuntalner, filli:is the reposting with a material which redures the access of ground water and retards the transport of radionuclides. finding a sultable rock type for the repcsitory, ard locating the disposal site in a remote area. Wuch effort has been expended in develop thesc harriers between the waste and the environgent. Human interference could perturb this aysten of bartiers and reduce iss effectiveness. For example, the system could be breached by incerceping the vaste through alnink or drilling. Or. Inadvertent intrualon inte the ropisteory systew could berome a posalbitity in the fueure if records are inst. ir meoury of site locations and contents becomes hazy. Thus le appears lamsteane that nuclear wante repontlory altes be arked, and that these arkers survive for an extended perind of tioe. The perind of intereat used in inls atudy (lin.min)

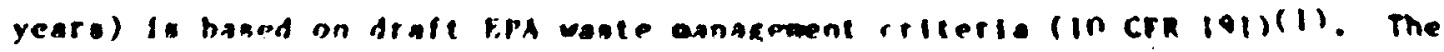

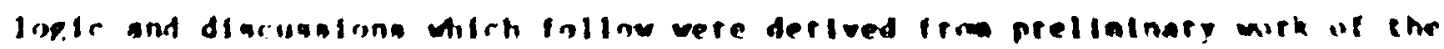

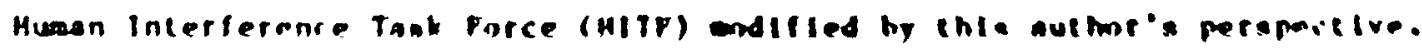

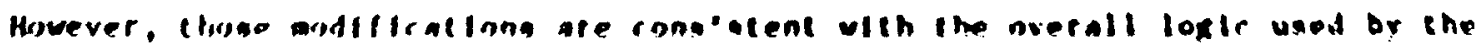
HITF.

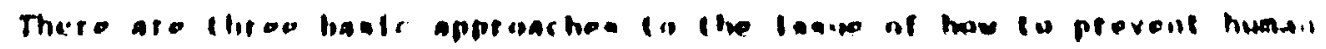

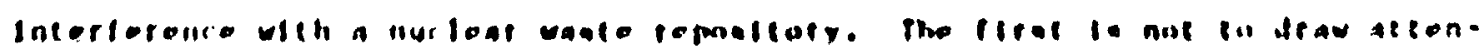

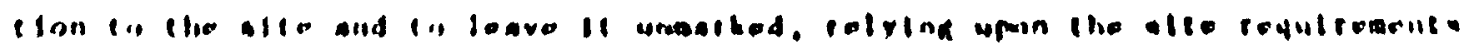

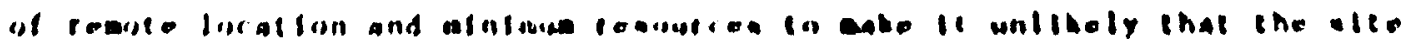

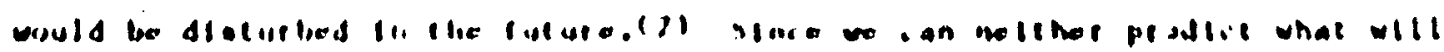

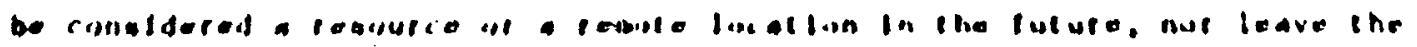

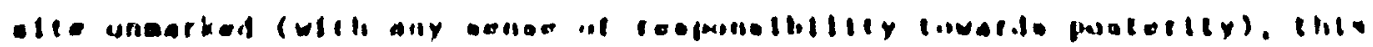
aporcarll I. met anteble.

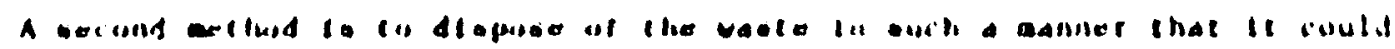

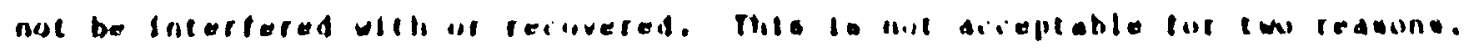

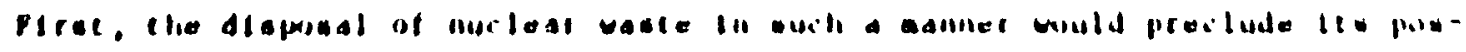

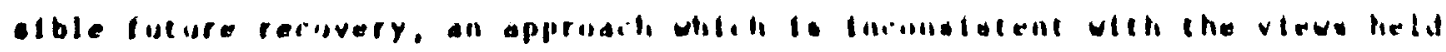

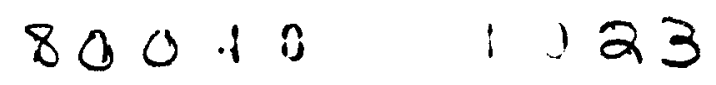


by the t.PA. $(1,3)$ second, it is unlikely that one dispusid botion, I repository system with disposal in a deep nine, could be desiginet whith cinde not be breached hy cechatgues developed by tuture cechnoloplsts.t bl

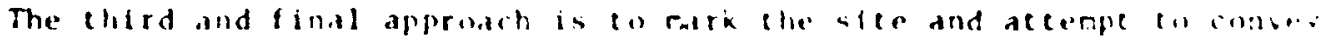
information about the repostenry location, concents, and assocfaced tiks e.

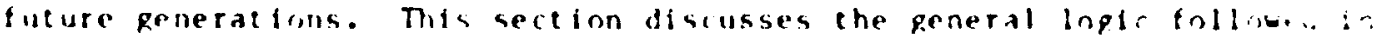

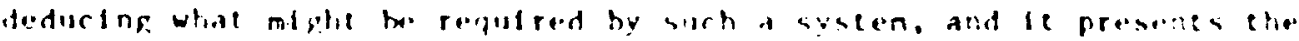
underlying reasontug which was tollowed when deslgnizg the syster presented in Chapter 4. An analytical frawevork for ascertaining the wedns pl whlith this Information can be conveyed is given in fipure :- I. The first chree polnis to consider are that the nessage must exist, he cetected, and be understiat in order to be effective. Each of these polnts is further discussed in separaie sections.

1i should be noted that the objective gf this work is to have the nessare underatood. The bepartment of Energy has taked the pasteton that this cenert-

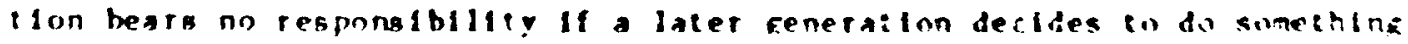

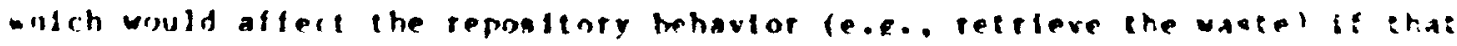
penetation ta tully cogntzant of tho hasated ard comaguences of tha: $\operatorname{artion} .(3)$

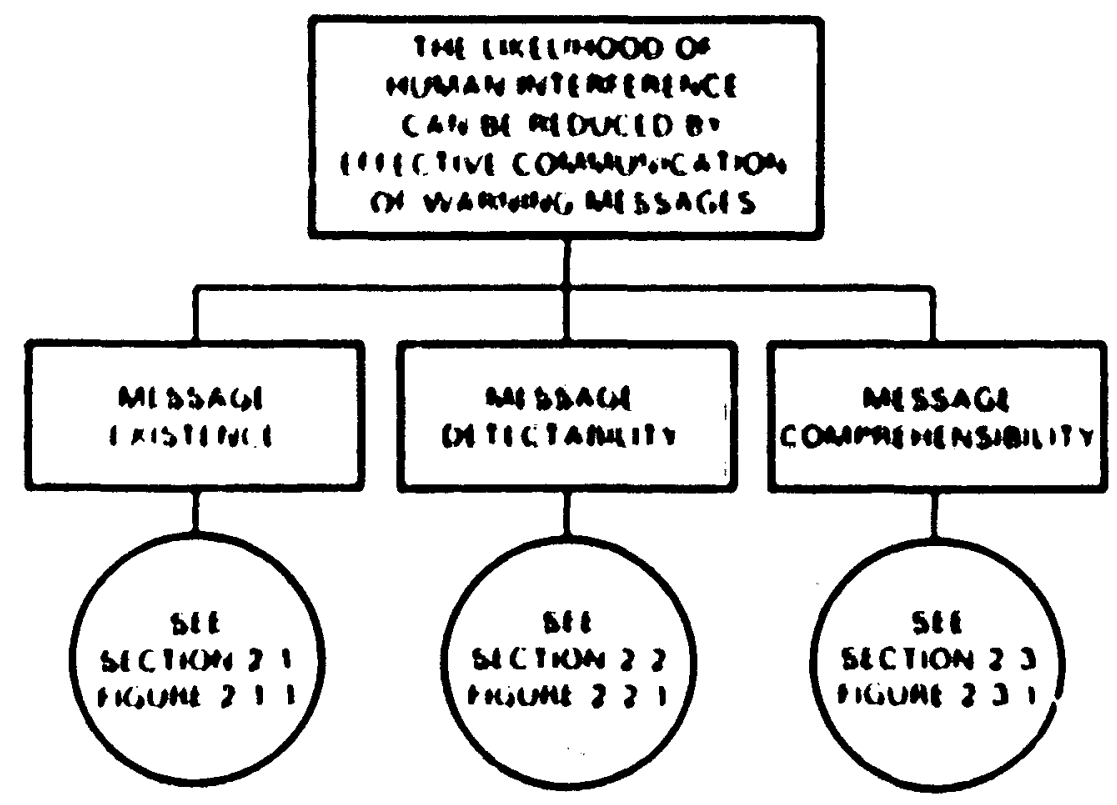

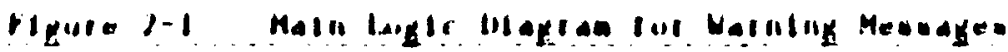




\section{I MESSACE FEISTFACH}

The dectston to mirk the repustiory ste meths that te has been derided that message to future fienerattons should extse. The nexe level je dectstun (ct.. Figure 2.1-1) Involves what should exist (bessige Jefinteton), where le should exist (message location), and how long li should exise (messige survivabllity). Fach of these factors is discussed below in separte sections.

\section{1 .1 Message Definition}

In order that a sosage ay wo conveyed ta future generations, wist first define what that message Is and the andience to whon it is adiressed. Although this report speaks of a mesage". I.r.. In the singular. there ary actually be several possible levela of Inforwition uhich can be conveved. For example. the mosagn can be ciasafled Into four levels:(t)

- lenvel 1: Attention-getter. I.f.. simpthing la here.

- Level 11: Attention-gotter and caralng, l.e.. sumething ls here and It Ia daneerous.

- lovel 111: Bantc Information. 1.e.. what, who, when, uhr, vhat ortlomn in arold, and where in tind inforbacion.

- Level IV: Full record of Information, l.e.p plane, Jrautnxt.

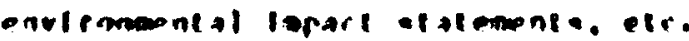

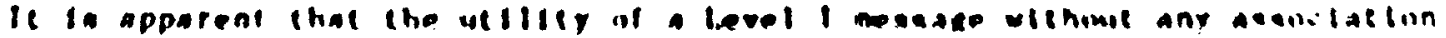

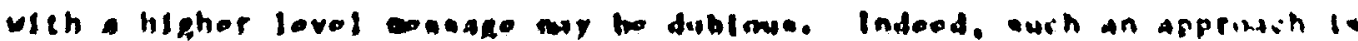

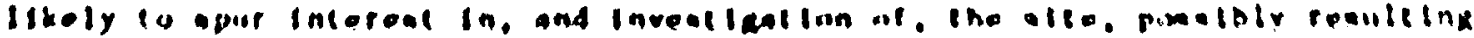

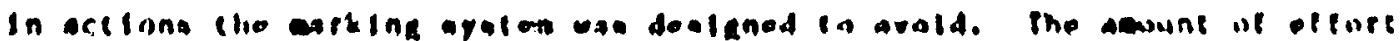

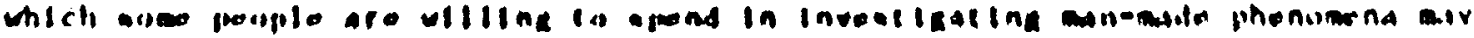

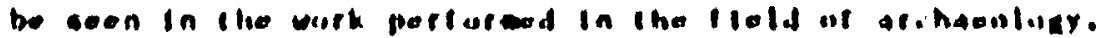

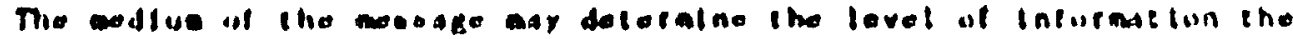

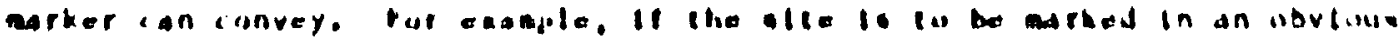

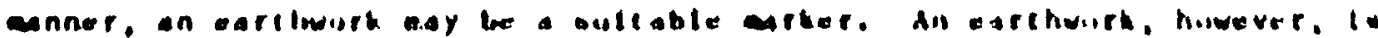

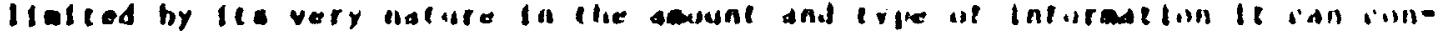

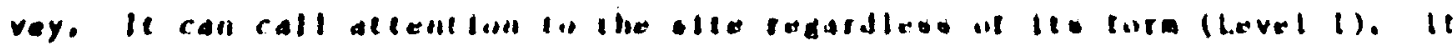

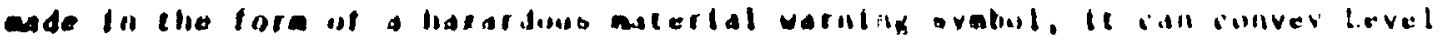

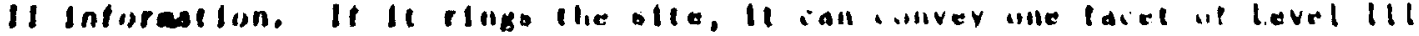




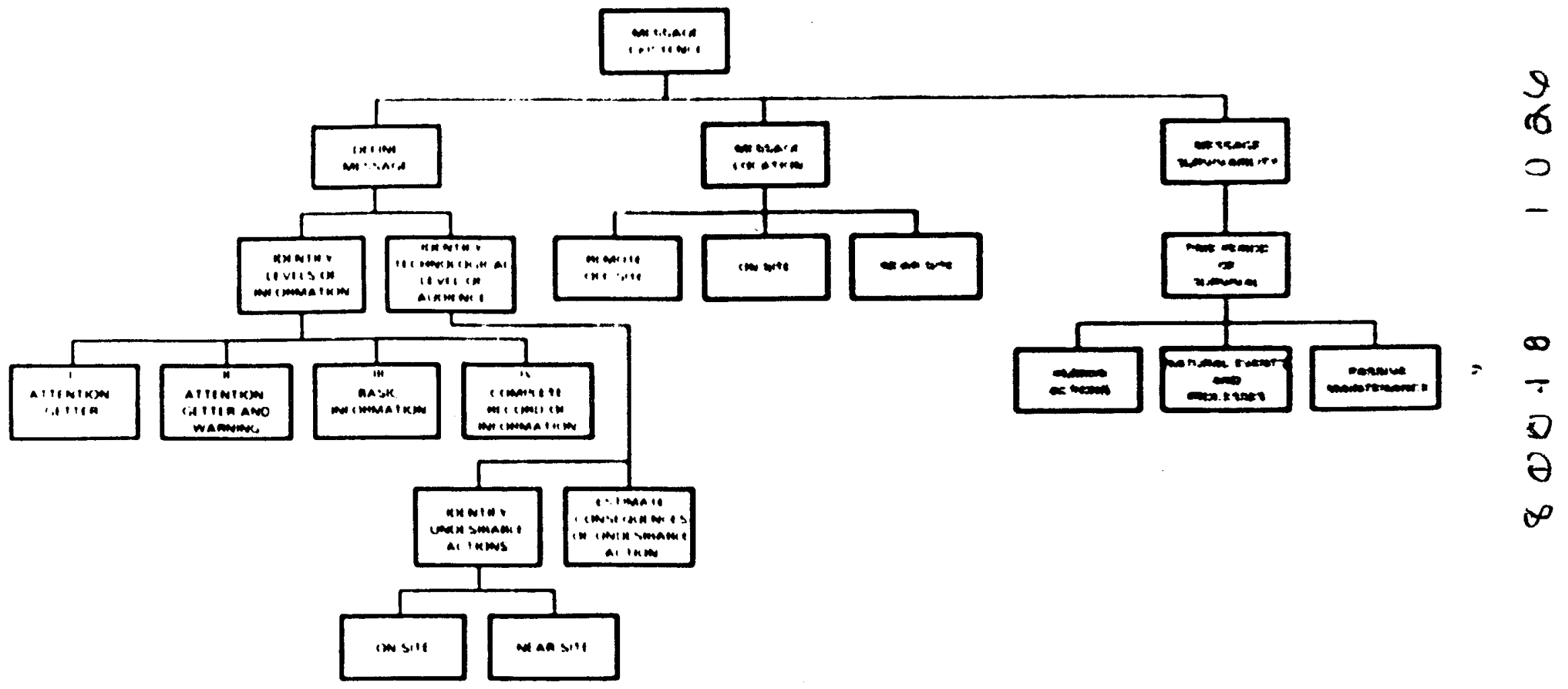

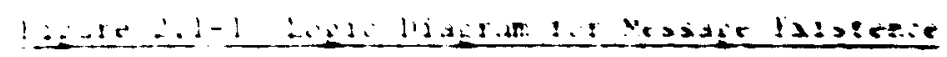


Information, but the Level Il tiformation ts los:. The difierelle ievels ist informition. therefore, may requtre different malit and metlods wi presentacton in order to he effective.

Another aspect if message definttion is the Identification of the audience to whom it is addressed. For the purpose of repusl:ory maring, the technological level of the audlence any affert how the wessage is struitured. In particulir, the technolngical level ay affect what is ment inned as actions to avold In the level III and iv ressares.

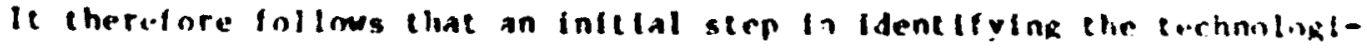
cal level of the audience is the Identiflcation of undestrable actinns or that

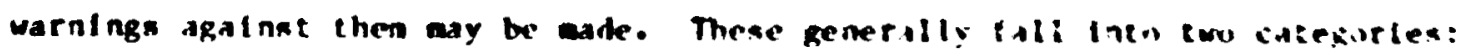
direct intruston inta the sice itself, and near-alte artivities. Direct

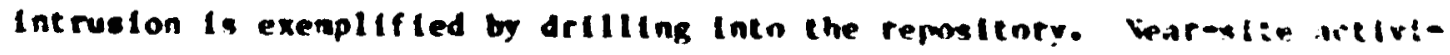
ties. though not at the atte itself, cowld dininish the effectivenexs of the

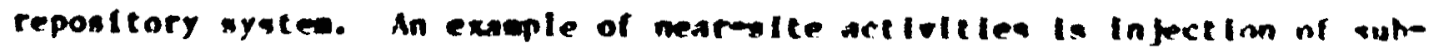
atancex Into the overlying aquifer wich would reduce the ablity of the lifulfer to recard the tranmport of radiolantopes.

The boundattes of the firat category of indestrable actions filtrect Intrunton) are vell defined, since they are set by the areat extent and tepth of the repowitury. It Is untikety that theme will change radicalty witin the

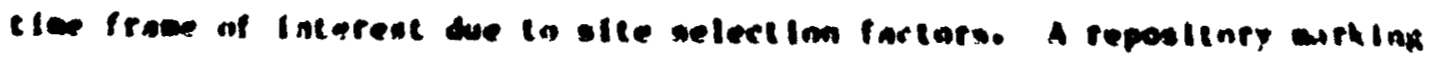

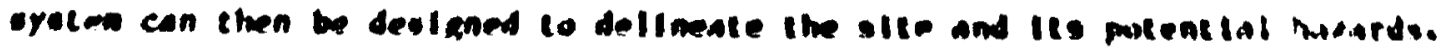

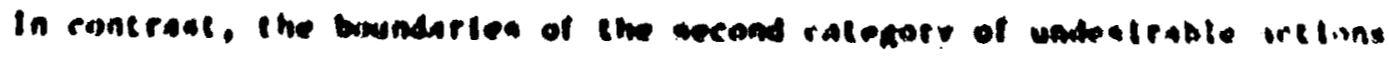

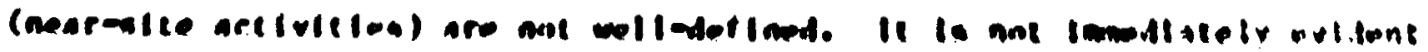

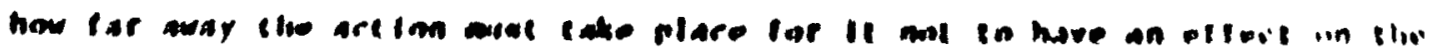

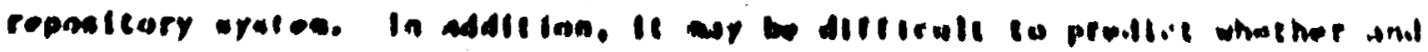

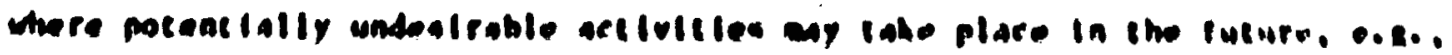

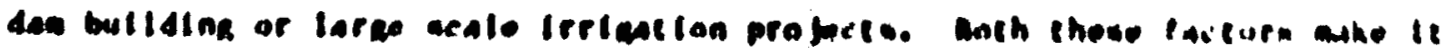

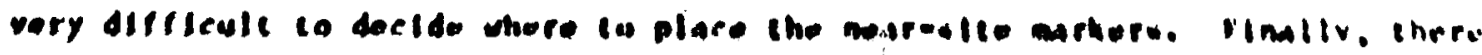

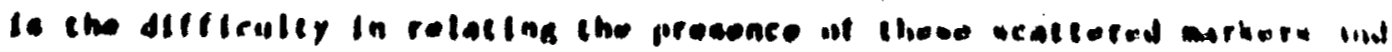

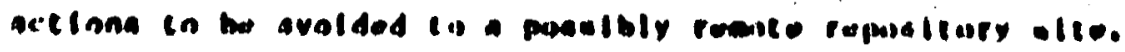

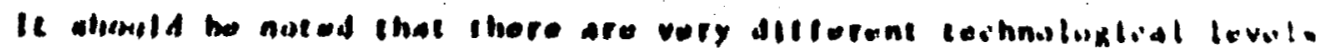

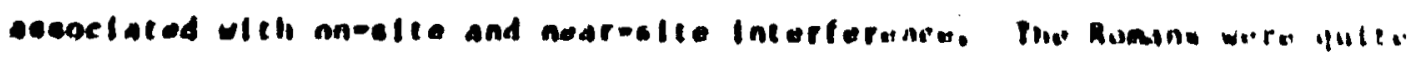

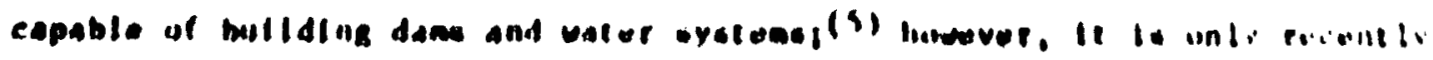

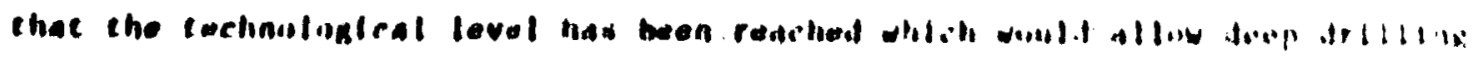

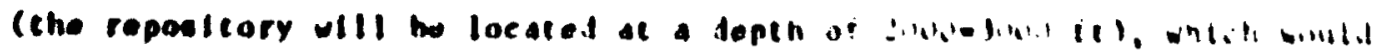
conat teute on-alte interterence. 
The site-specific safety analysis which would be undertaken dt a reposicory stee could bo lit llined here. First, the anilysls wimld collsider blinse actions and thelr consequences whlch would he detrimental to the reposteory system. This work may also facllttate the identification of a buffer zone around the repository to protect against actions such as drilling. If this can be done, then the reposttory site, plus buffer zone area, would be the area tu mark. This still leaves action which may take place at some further distance from the site, e.g., dan millding, to consider. The safety analysis could deceraine the severity of the consequences if actions such as dam bullding were taken. Given the potential difficulty In arking such a nedr-site ared and deternining the actlons to be avolded, the results could be used as part of the stie selection process. t.e., to judge whether a repositury shnuld be placed at that site. Finally. this Information mouid be sultable to inclide In the level IV sessage so that future generations could ake an informed dectston on whether to take a certain ection.

\subsubsection{Mesease Lecetion}

All four cessage levels should be located on the repostiory olte. In order to phyatcally connect the concepts of moclear mate burtal" and "burtal

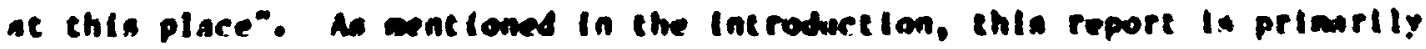

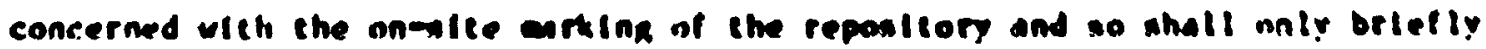
discuss the off-ite conveyanee of information. The offosite informition should be located in muerous places. preferably worldewlde. in Increake the Itketihond of the aurvival of eame coptes even If Iacal Infurast ton blackowts

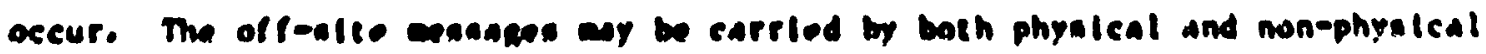

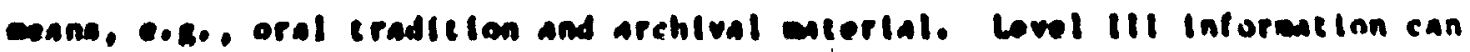
bo conveyed by auch coane ae havina the ate Incation donoted by the hatardous

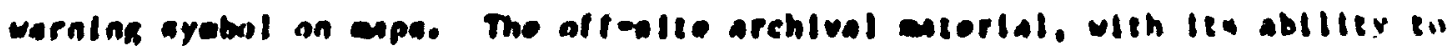

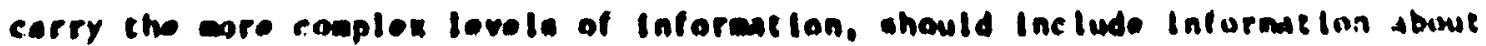

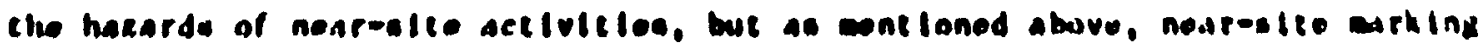
for all undealrable artione woy not he appropptale or teastble.

\section{1 .3 Heanage Survivabilliy}

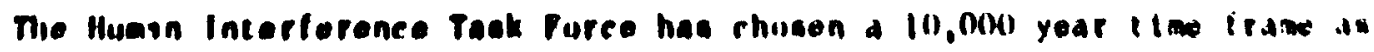
the porlad for which the eartors nood in aupvive. based on RPA drafl
") " 40
1028 
criterta. (1) There is a distinction drawn here betseen the durabllity of a message and the ablltcy of that message to survlve. Ditrihtllty refers lil the longevtey of a miterlal if te ls left undisturbed after placemeit. Survivablltey tikes Into iccount not only the durabtllty if a metertal, but lis llkelthoid to withetand humin ictions is well. As such, survivahillty reflecls a combination of factors, each of which is described helow.

Archaeological evidence indicatex that human actions are a priac fictor tn consider when assesalng the potentlal survibabllity of the arker systea. This factor can affect the cholce of aterlals: wetals any not be sialtable because of their ablitty to be recycled (cf. Sectlons 3.2 and 4.1 for examples and further discussion). Removal, defacement, and randallsa are all possibllteles to be considered. Chapter 3 contains exagples of wat has happened to sone notable wonubents at the hands of an. The reesons for rewuring we Jestroying conuments are varied, ranglng frow Iconoclasa to msetu acquistiton. and the arker aystem ast be deslgned to ake rewoval andfor destruction undesirable or difficult to do.

Human actions can also Indtrectiy affect the durablitig of nirkera. For exaple, Induntrialievtion hes led to acid raln. wich is having an adverne effect on any enctent bonmente (section 3.1.3 discusses its effert on thr

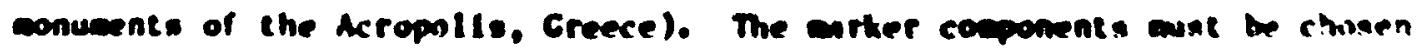
with this phenowenon in at ind.

The arker eyetes should alwo be abie to wingtand the meturel erente and

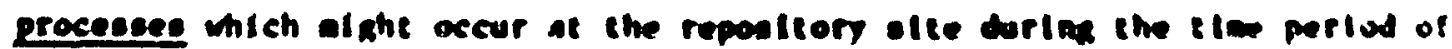

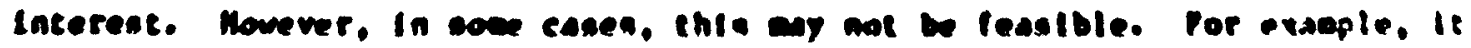

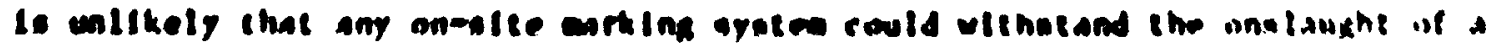

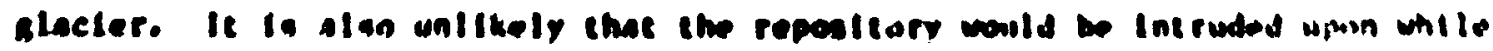

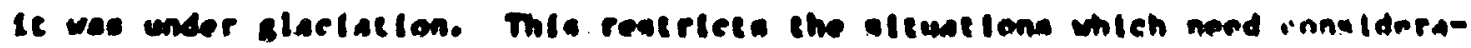

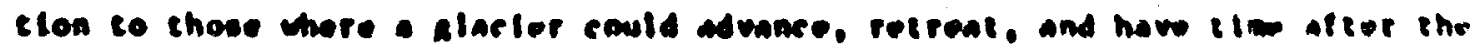

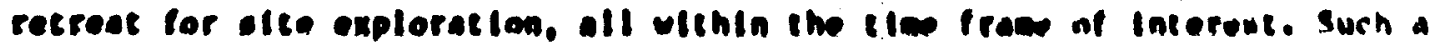

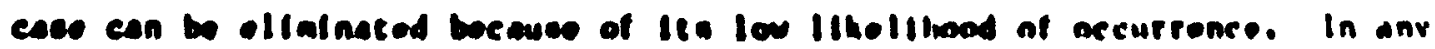

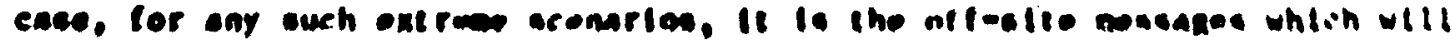
coat inu to canvoy the information.

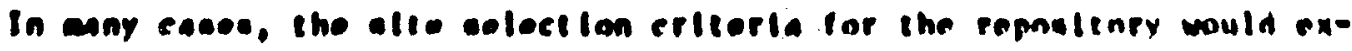

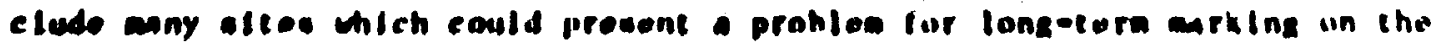

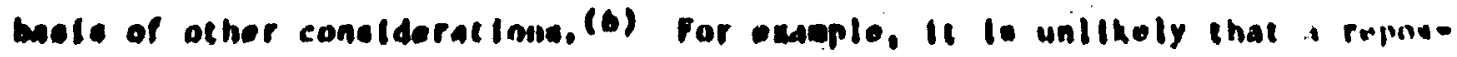
teory would bo lorated In an area In which labe furmation, guvore tlowillid, ur

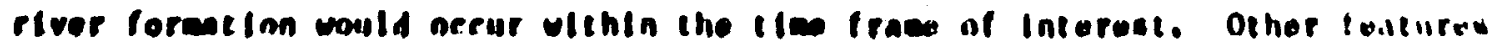
$87 \cap 40$
10.9 
of the marking system, e.R., height of the markers, or whether they should be placed on platforas, could be chosen with consideration of site-specific factors such as soll erosion or deposition rates.

Finally, the arker systea wat require no active ealntenance. Such anintenance cannot be guaranteed and to requite te would be contradictory to the Idea that the generation which recelves the benefit of nuclear power should place no burdens on future generations for its disposal.

\subsection{MESSACE DETECTABILITY}

The nessage wat be noticed in order for it to te effective (Firure 2.2.1). Th1s brings us to the questlons of the distance at wich the wessage should be detectable and the ceans by wich it ehould be detectable. (As -cated earlier, this discussion is concerned with the besese at the repository atte itself. It does not conolder offolte informtion ouch os warning syebole on epe or reports etored in Iibreries.)

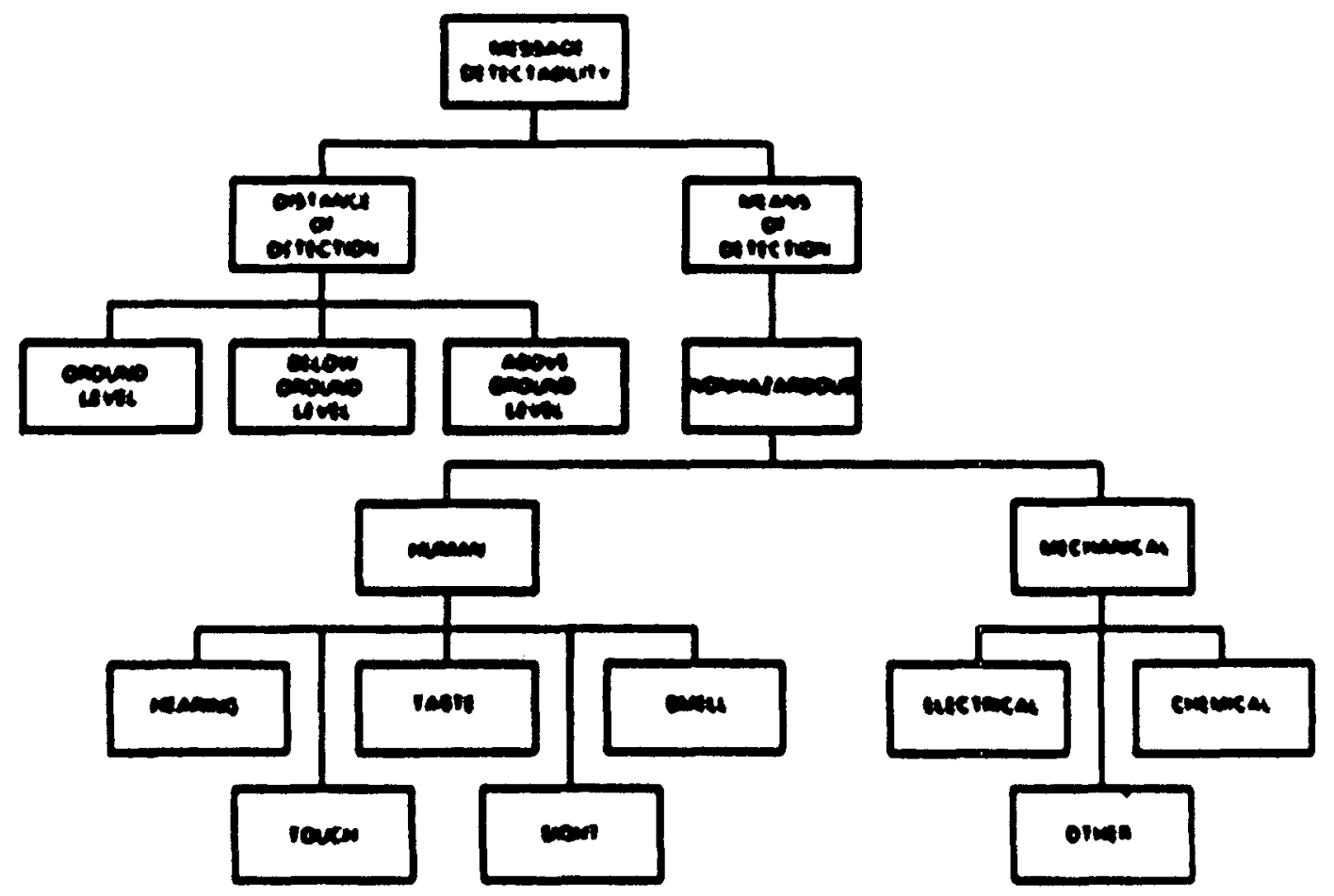

Digure 2.2-1 bole Dlogran for Mopose Detectabllily

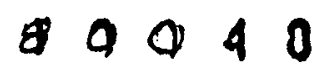




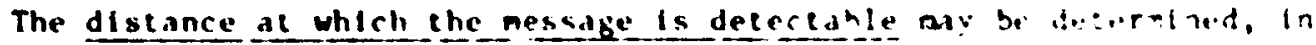
part, by wether it is desirible en actlve: ra: titen:lon en the ite wr te warn people once they have decided ts Investigate the ired. For eximple, if

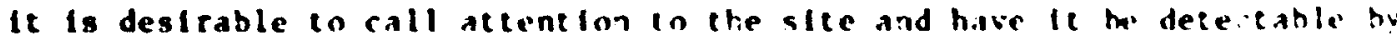
reoote wethods (e.g., acrial or sitellite detortion), li la possibla to tike such weasures as creating a agnetic anoesly ur changing the veretation at thr ste. Such an approach could carry level I or ievel It information (if the umsual feature takes the inm of the hazardmis materlal warning syobili, mit no higher levels. ThIs approach, hmever, ay crigker furthet Inves: latilins of the area where none had been previously planned. It ay tsu se superflums level of redundancy In the arter arstea deslgn, stace whether the reposttory iw knmon or not leed at thls distance will not affect the hahiulise

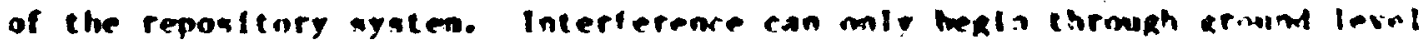
artivitien by an or enchime. (lit is beyond the acope of this remir:

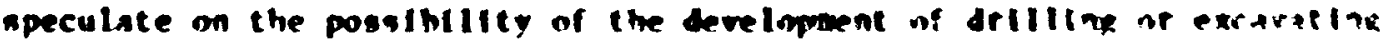

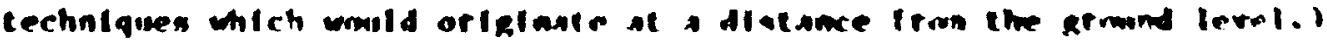

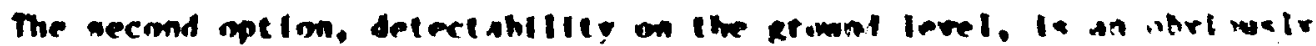

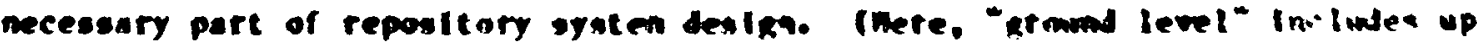

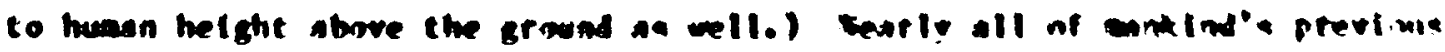

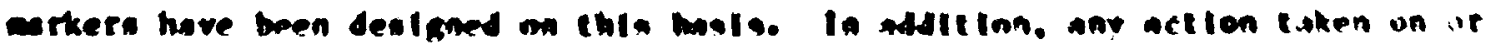

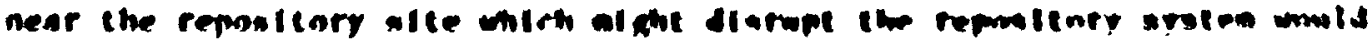

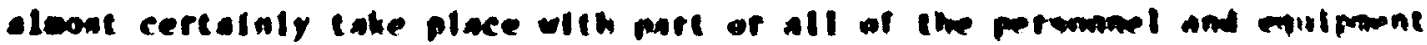

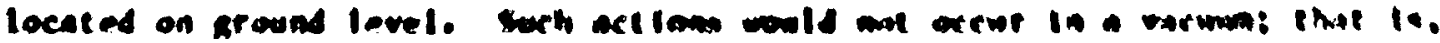

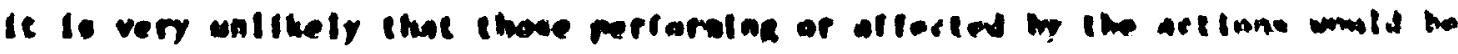

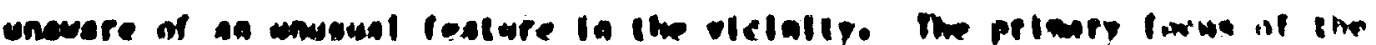

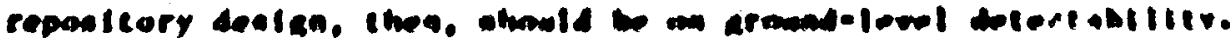

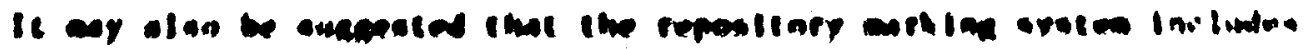

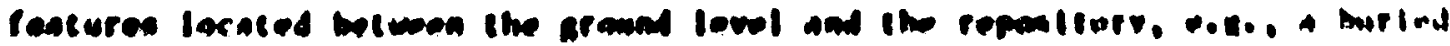

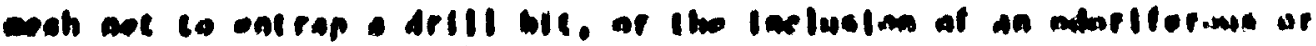

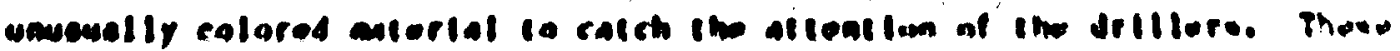

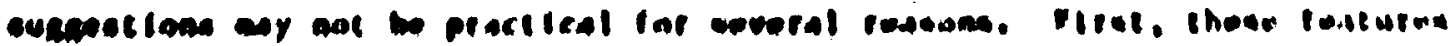

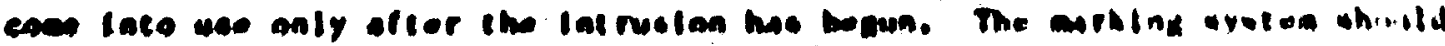

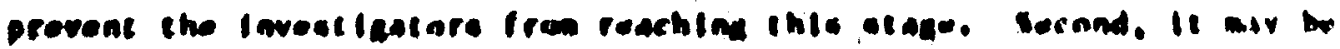

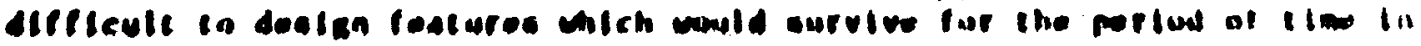

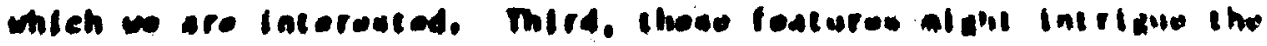

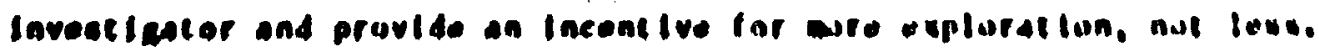


There are tal keneral geaus of Dessage detection: by hurdns is by wihine. In elther case, the weans of comunlcating the message cannot be hazardous ir requlte in energy supply in order to function. The human means of detection, the five senses, provide us with a baseline for the destgn, since these are not expected to change nver the ctwe period of interest. It Is difflcult to concelve of a essage and/or warning which could be conveyed to the senses of hearing, tasting, seelling, or touching which would be practical, nonthasardous, and pasatve. Gulte the opponite is crue for the sense of sight; the anclent comwents and arkers whlch have survived äppeal to this sense. It is for this reason that the primary emphasis of the dealgi presented ia Chapter 4 Is based upon detection by hasn sight.

Detection by achimes can occur by the Interception of vartous zypes of uignals. e.s., electrical, agnetic, cheblcal, and so forth. Mis approain ay not be practical for several reasons. It is not possible to predict whit type of signat asy be searched for by foture techmingles: It way be one whish

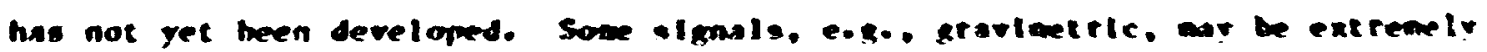
difficult to iaplenent, wile others, e.g., chentchl, ay be makardous. The

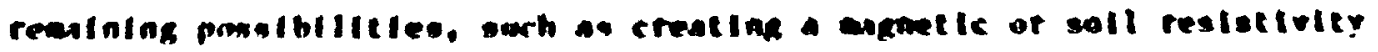
anomaly. can carry only the first two levels of informatlon. For these

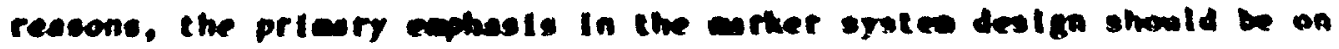
setection by sight.

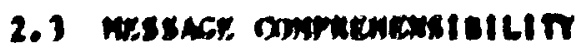

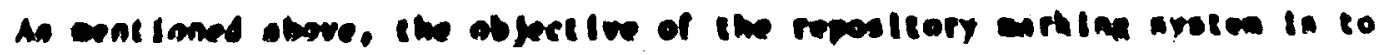

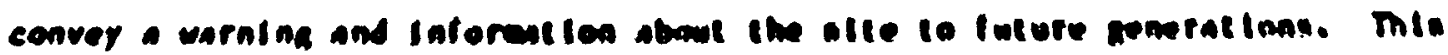

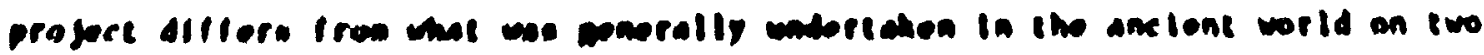
notata.

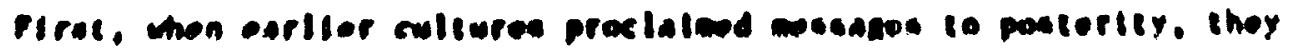

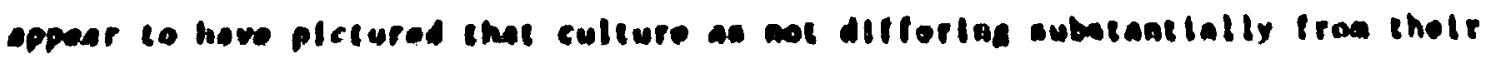

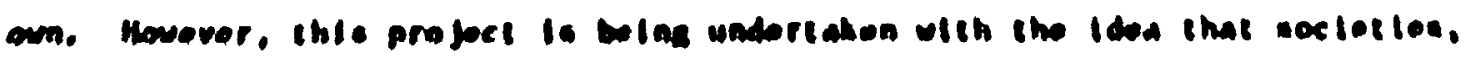
cultures. and languages any change drastically within the time pertod of

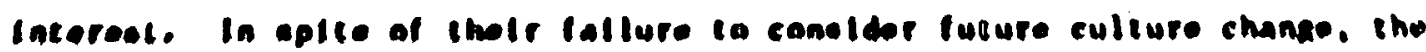

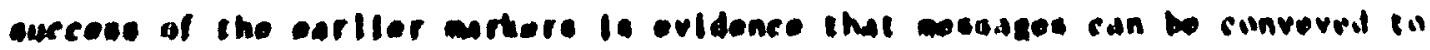

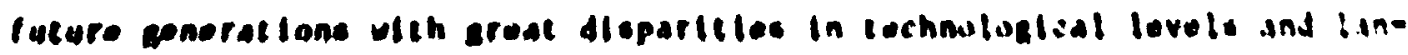

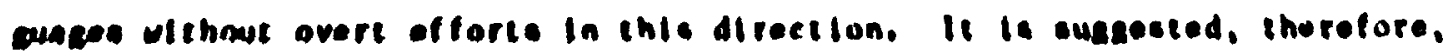

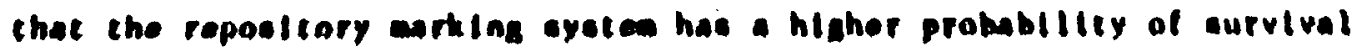
i) $09 \begin{array}{lll}9 & 9 & 0\end{array}$
1032 
and understandablitty since it is being deslgied with culture chinge la nind. And, since we cannot predict the changes wirh wll occur, we idi use nur present languages as part of the wessage and know we have done no whts tha? the anclents.

The nessage ust not only be understandabie, but bellevable. This is a second difference between prevlously ade wessages and the ones designed int the repository system. The anclents placed warnings and lapediae- is it the way of Intruders because there wa sonething for the Int rudet had reason in think there was sonething) of value stored in that place. The bullders designed a curse or threat to frighten off persons who sought the wetith. Thut thetr curses falled to drive off tonb robbers can be seen in the wide extent of this type of intrustow. The excevation of the toos of fotanihasun ireated such a stir because it had been fifled only in almot way. An exanple nf

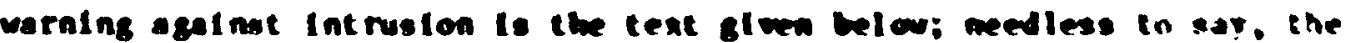
Imcription was found over an empty tobs.

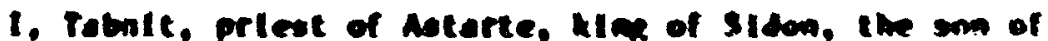

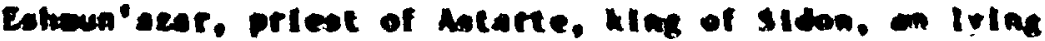
in this sercophagus.

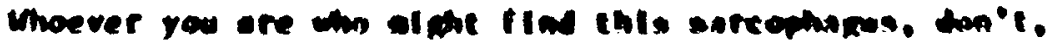

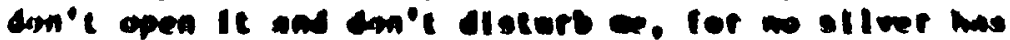

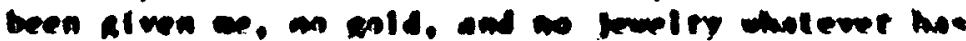

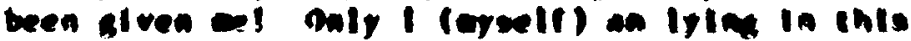
sercophegue.

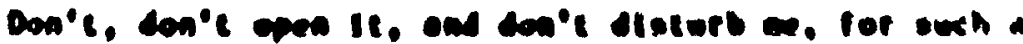

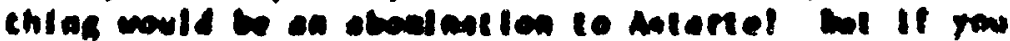

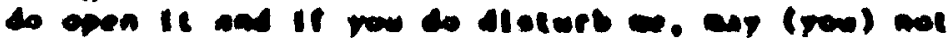

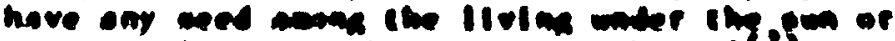

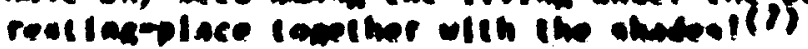

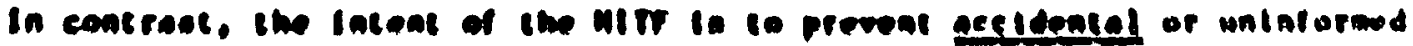

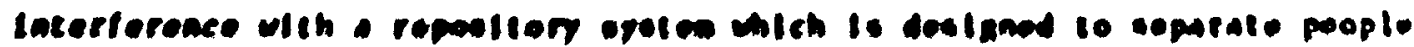

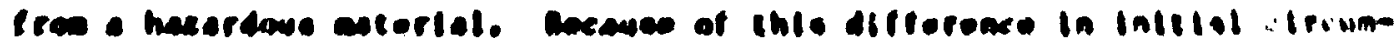

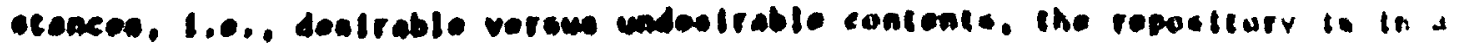

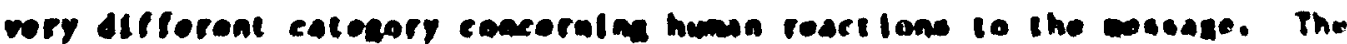

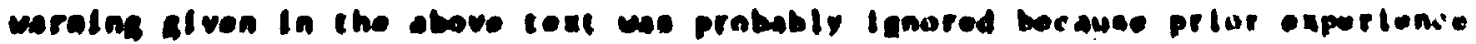

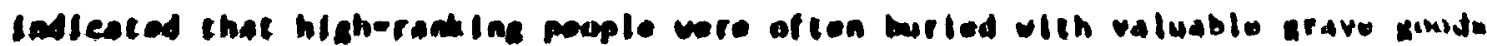

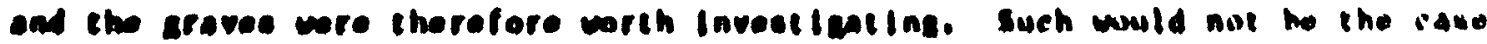

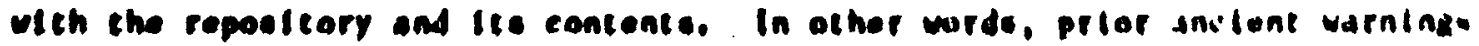


were to protect the tomb, and tes contents, 1.e., Its owner, thile the reposteory system warnlings are to protert the intruder. To thls writer's knowledge, the incent to mark a hazardous waste ste for such an extended perlod of time for the purpose of protecting the potential intruder is unprecedented. It cannot be guaranteed that the Investigator will heed the warning even if it is understood. An analogous steuation is che warning placed on clgaretce packages. In elther situation, the Individual or Investigator bears the responsibility of his or her actions because the decision to act was taken with knowledge of the potent lal conseyuences. (4)

The eaphasis in this report, therefore, is to aake the wessage as comptehenstble as possible over the tive frane of Intereat. The nessage nay bc conveyed by three different mans - spobols, plctures, and by languages (F1gure 2.3-1).

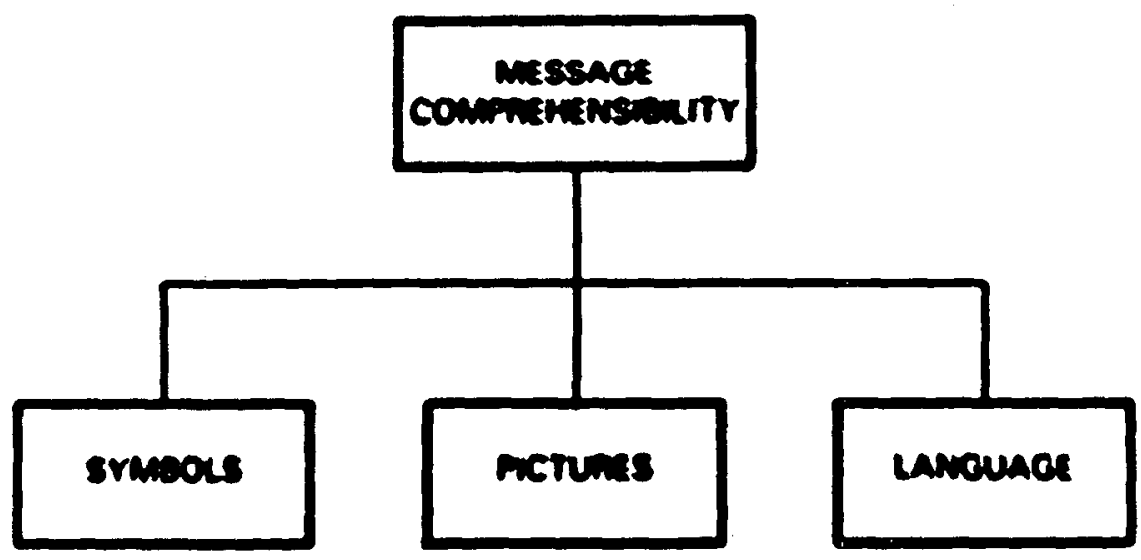

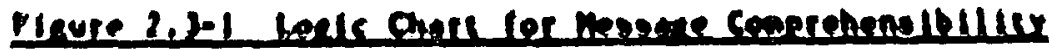

Srabele can we uned to convey Level II Iaformation on the alle lenoll and

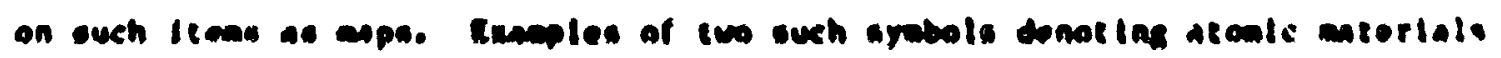
are givon in Figure 2.3-2. Twe one on the lefe is atondardly done in angenta

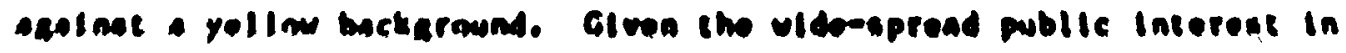

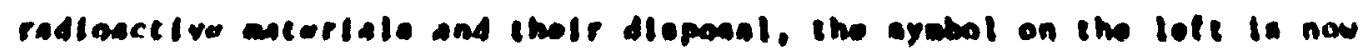

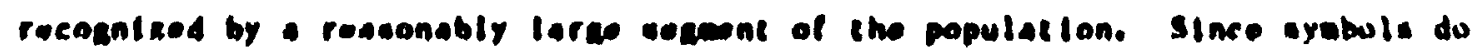
abl rely on languane. thoy ay we eare adaptable for panculturat wase auch an this. although they auet learnod by the publte.
80818
1034 
1.
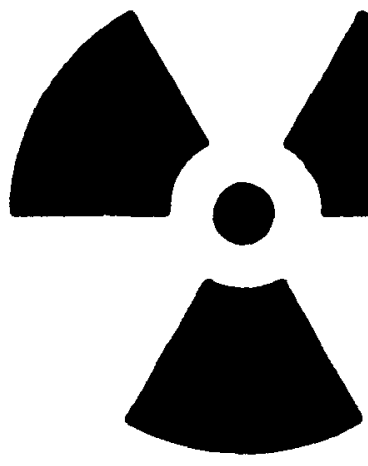

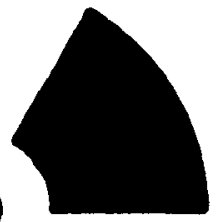

Figure 2.3-2 Exaople Sybols Used With Atoalc Materials

Plctures are an obvious weans of coemualcat Ing Inforation vithout written language. For exmple. PIgute 2.3-3 shown a stat we bing draxked by any people, something wich is disceralble even though wost renders of this

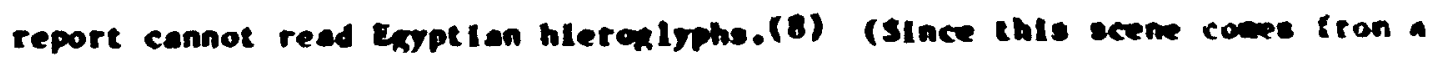
3,800 year old tom, It is en exrellent Illuatration of the potential for

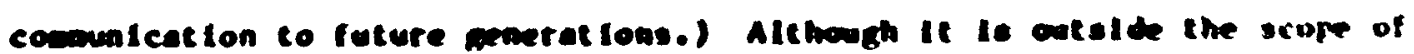

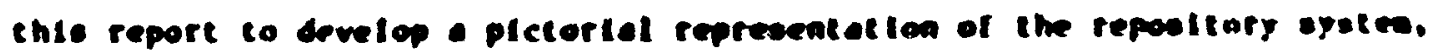

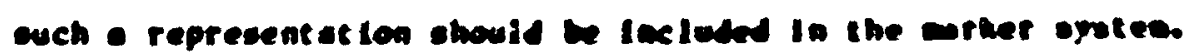

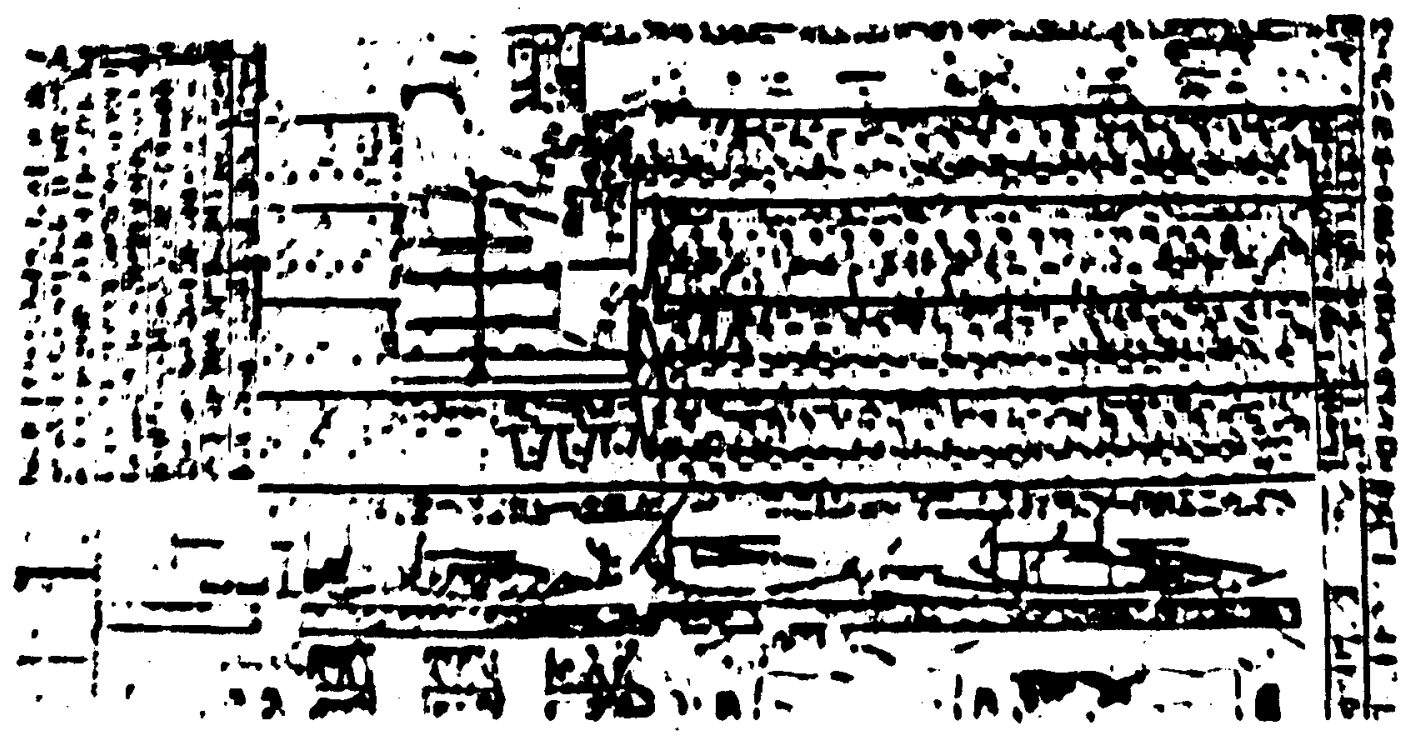

Pigure 2,1-1 scene proa Toab of DLehulyheles Tranaporilne staiue in shilne

$80010 \quad 1035$ 
Language is the third option for conveylng Information. itven the the I rine involved firr reposleory arkera, it is extrewely unlikely chat finglish wll not evolve signiftrantly from its present fora. For example, wost native speakers of linglinh can read Shakespeare (c. 1600 A.D.), a feu can muddle through the orlglnal Chaucer (c. 1400 A.D.), but wost could not redd the wriginal Beowolf (c. 700 A.D.). Yet it should not be overlooked that the latter two literary works exist in modern cranslations and are cherefore avallable to a wider audience. A siellar phenowenon way be seen In the cranslaclons of the Creek and Figytian ayths and hiscorles, as well as the burial inscription quoted above. There are two points to be noced from this phenusenon. First. it appears that if the mexsage is of suffictent Interest. It will be inslated or "recencoded" Into the langueses weed at that tine. If the level of Interest In the disposal of muclear waste is Indicative of fucure Incerest. the message is likely to be terencoded. Second, the dessage need nut be lamediately readable by all mexbers of the general pablic in order to have the Inforation survive and be dissealanted co thit poblic. As long as sueve people can read anctent Iangunges. The wesage can be translated fur the peneral public.

In other words, whould melther oneflod nor domplay the potent ial for lenque to carry informtion about the repository. Lanange also Mat the

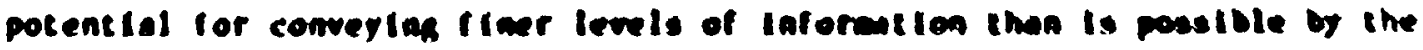

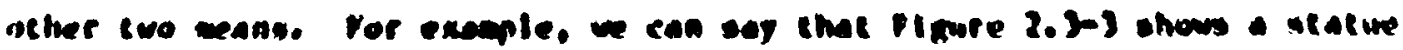

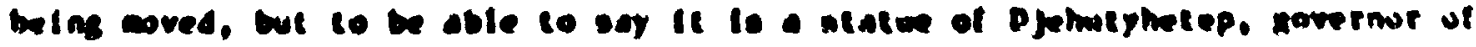

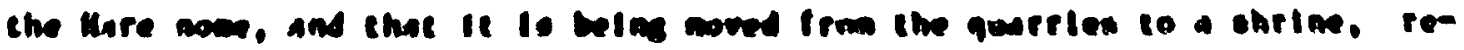

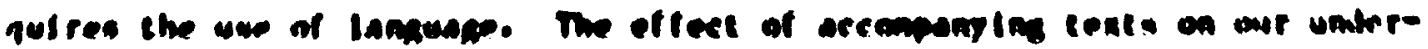

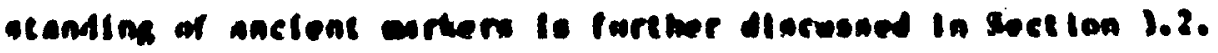

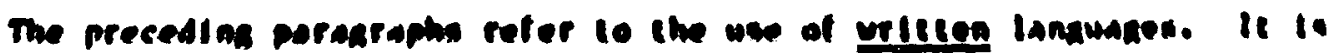

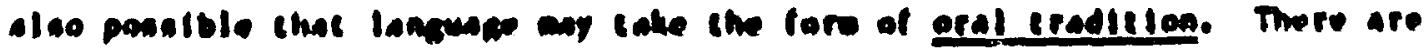

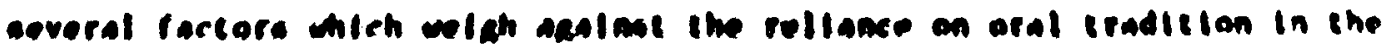

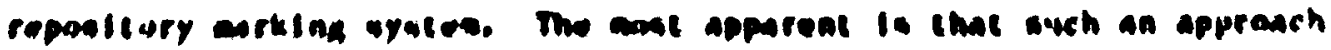

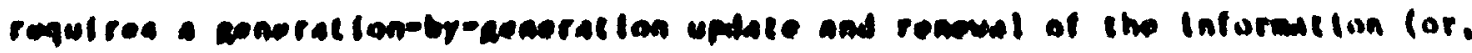

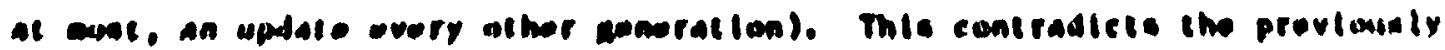

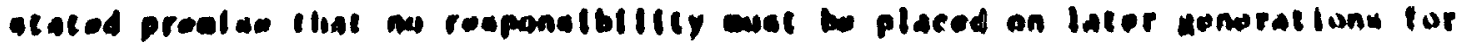
the corking of the repadiciry atte.

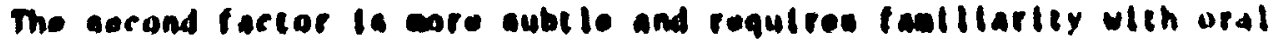

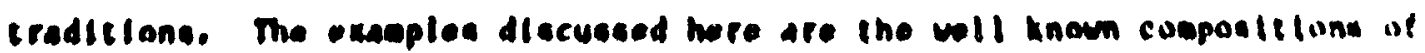


Honer, the 11 lad and the odyssey. There is litele doube that these ser. orlginally oral compositions. There bere ang verstons of the Humeric epliti when they were first written down, c. fifth century B.C. There were atienpts to collate, reconclle, and edtl the varlous versions by the third ieitury B.r. Even after the outstanding work of a Howerle critic in the secund centur: B.C. there were st lll "ulld cexts (1.e.. Those whlch differ in lengeh ur ill substantlal wording of the (ext), though these now were wre the exceptiun than the rule.(9) But once they were written oul, lt was the literdry tradition, not the oral, wich preserved Hower's eplcs to our tiae.

Research and studies of modern "alngers of tales" priarity thise in the Balkans, are the work of Parry and Lord, and it is useful to qunto ane nf the later's comments:

If the singer of oral eplc tradtion aluava wank ann: In exactiy the sace words, it would be posslble, nf course, to ank hit to repest the performance nuber nf tines .... but barde never repeat a son exactly ....

Those singers who accept the Idea of a fincd lext are lome to oral traditional processes. (iO)

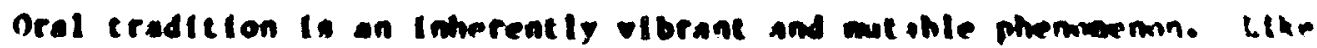

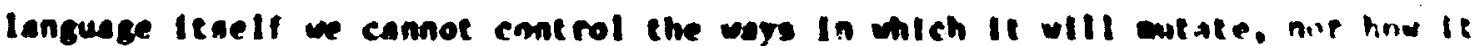
w11 change with each gemeration of tramealioston.

Hureover. Lard Indiraten that the oral and Itterary iraditions aro

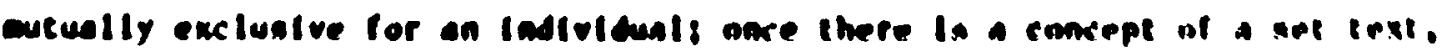

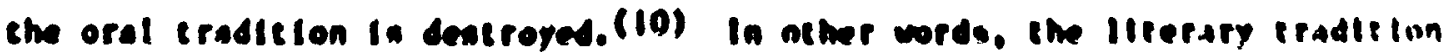

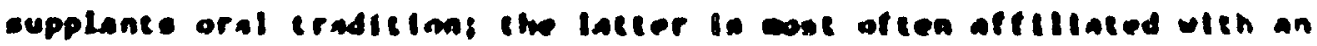

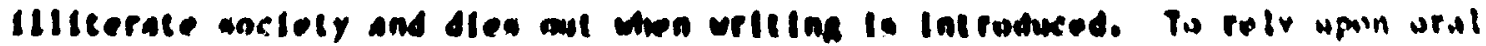

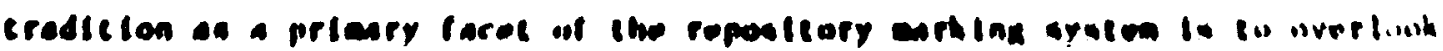

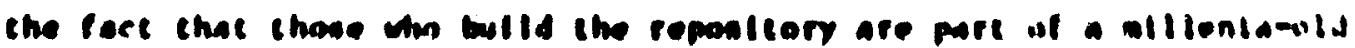

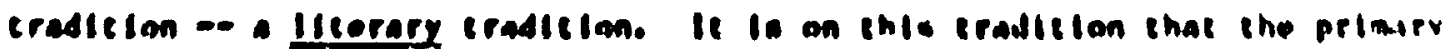

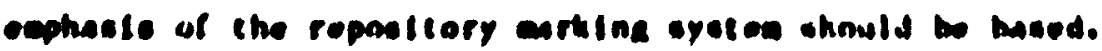

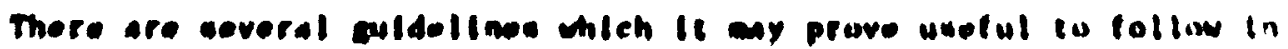

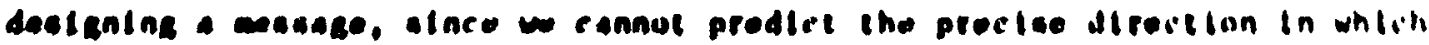
Iangungea will evalves

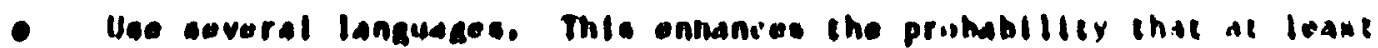
one of then vill bocigntioblo and dectphorablo. 
- lise languages currently in widespread use. There are more speakers of tinglish or Spanish than there are of Esperanto, although the latter is an artificlal language designed for International use.

- Try to avold fargon since lt has a liglted audience and IIngulstic It fet ine.

The use of language, In conjunction with syabols and plctorial representatinns. should provide the weans for conveying different levels of inforation about the reposicory. This redundancy in the design will enhance the posatbility that the Inforation wll be comprehensible to future investigators.

\subsection{SUMURT}

In the discussion of the potential probles of huan Interference. there are several aspects of repository urther eyste desigh which rest upon factors deternined outside of this report. e.g. techmological level of the eudience. and distance of detectability. Several goldelines, however, becous apparent. Given the difilculty of carrelatias the repolton with seeralte features and

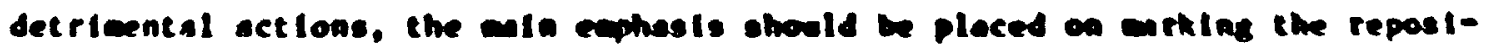

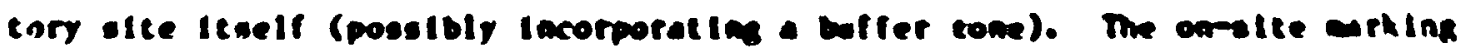
uyaten should Incorporate all four levele of Iaformation ll.e. from an

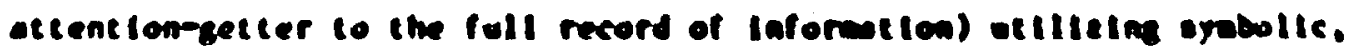

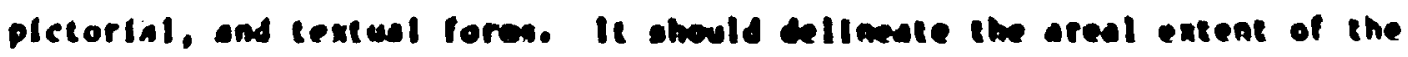

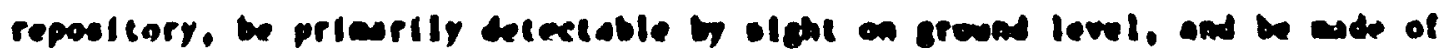

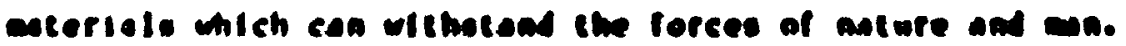


This section will investlgate several anclent, wan-ade sonupents. Section 3.1 is primarlly a arker-by-earker description, providing the Inforeatinn and backgruund which is drawn upon in the repsitory arking systee design presented In Chapter 4. The warkers were chosen to represent a vartety of cultures and clleates; the former to Indicate that the aaking of conuments and their survival is not keyed to particular culture, and the latter to ascertain the effect of cliate on survival. Since we are interested in survival, each of the arkers had to be at least one thousand years old. Some, as we shall see, are fire tiwes this age, whlich laplies that chey have already lasted for half the tine perlod In which we are Interested. These arkers are:
- Pyranids, Exypt (Section 3.1.1)
- Stonehenge, England (Sect Ion 3.1.2)
- Mazca Lines. Paru (Section 3.1.3)
- Serpent hound, Ohio (Sect $10 n$ 3.1.4)
- Acropol1s. Greece (Section 3.1.5)
- Great Vall. China (sect ton 3.1.6).

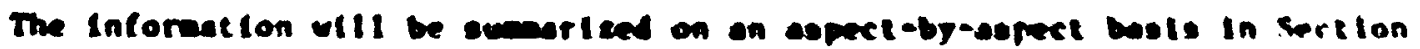

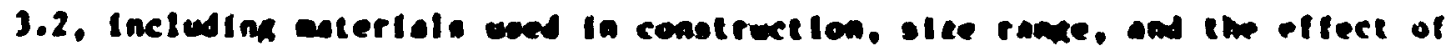
contemporary cents on our undereconing.

\section{1 sacetro axampls}

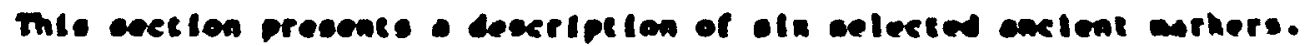

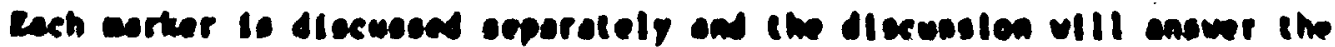
tollawing quet leass

- Chet - chas is the earter and freo chat aterials is is mandacturals

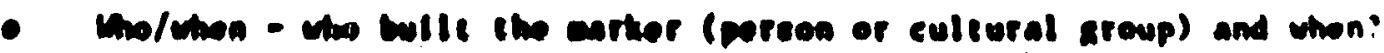

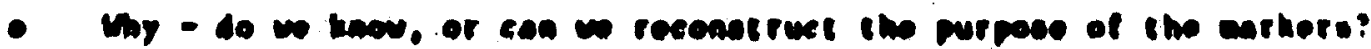

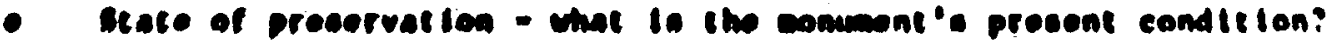

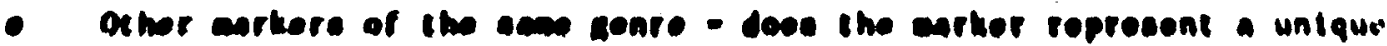
foature chleh aurvived, ar does It represent an enemplar fru a nuber of ourviving enterel

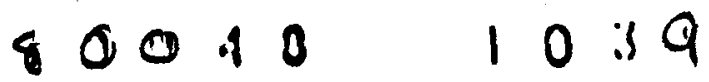


History - how fir can we trace the history of the monument? usetul in doslgning a repository airklng sustea?

\subsubsection{Pyramids, Egypt}

A wentinn of "Egypt" conjures up tages of the Sphlnx and chree enornous pyrastds at Giza near Calro (figure 3.1-1). The Great Pyrasid was bulld by Khufu or Chenps, as the nase is preserved in Greek historlcal texts. It orlginally measured $756 \mathrm{ft}$ on a side and stood tn a helght of ill ft. It now stands $450 \mathrm{ft}$ tall and 750 ft on a se due to the Inss of the ising stines.

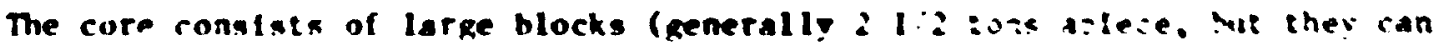
range up to 1 ; tons) of local IIbatone taken from a mearby quarty. The

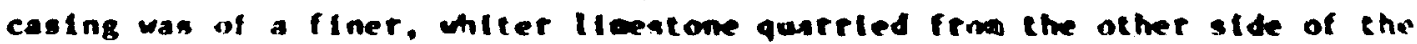

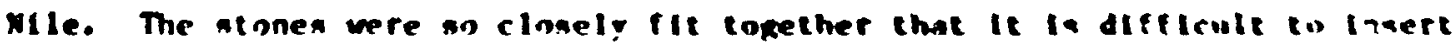
even a knitio hlade helumen thes. The pyragid underwent ihree chankes in plan wili It wan under construction, each aithed hy butial chaber. The fimal chanber ia IIned, roofed, and pared with womblithle araatie slabs: the ronf

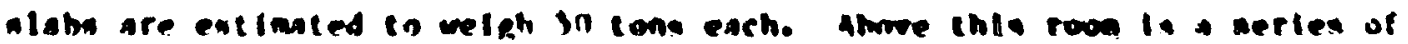

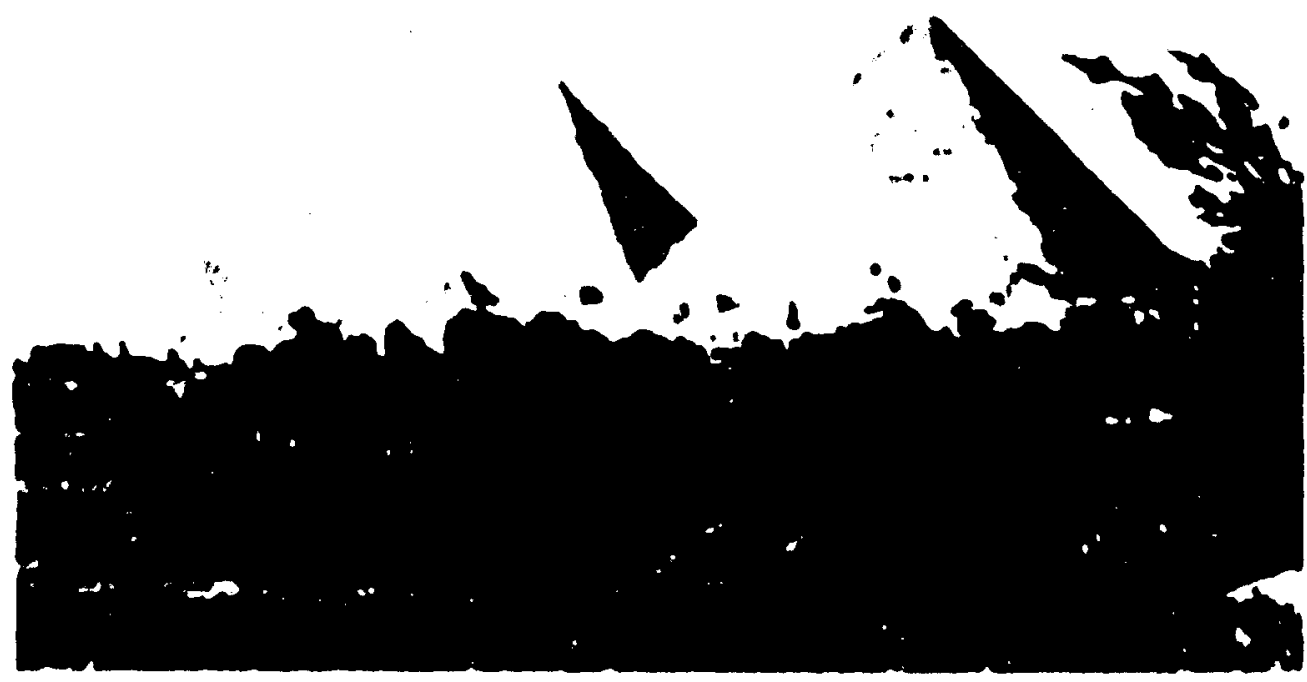

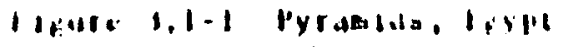
80010
1040 
five chanbers lo relleve the welght of the upper portions of the pyramid irum the burlal chanher. The name ni khufu appeirs in the quarry mirss in sune' it? these stones. $(11,12)$

The second pyraid was millt by khafre, a son if khufil, and it orlalnally measured $708 \mathrm{ft}$ on a side and was $47 \mathrm{~s} \mathrm{ft} h \mathrm{~g}_{\mathrm{gh}}$. Like the earlier pyrdald i: was ade of a local lisestone core and finlshed with a white lisestone layer. Part of the original casing still reailns on the suente. The internal plan is siaple, with two passageways leading (o a single chabber. (II)

The sphinx is part of the pyranid coeplex of Thafre, but is a unique feature. It appears to be a gifted archttect's way of changing an eyesure Iato thing of beauty. The Sphinx lies within the quarry for the llaestone blocks used in the conatruction of the varlous pytaat and their concuadtant bulldings. The best and hardest stone was chosen for the proalds, learlng a ass of softer rock jutting out from the querty bed. Mis eyesore wa transforned by Khafre's archleece into the nearly 70 fi tall Sphinx.

The third pyratd, bullt by reakure. Is the sallest of the three (350 ft square and 218 (t $h(g h)$, but its alce we offeet by the wse of grantite caslag on et least the lowest inteen courses. It was oflelablly planned on

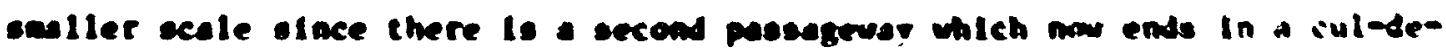
cec with the pyraeld etructure. (II)

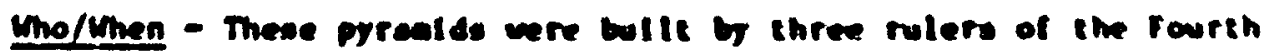

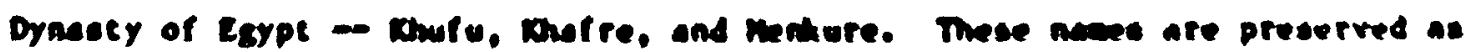
Cheape, Chephren, and Nyeertans by the Sth ceasury B.C. Creek hiaterlan

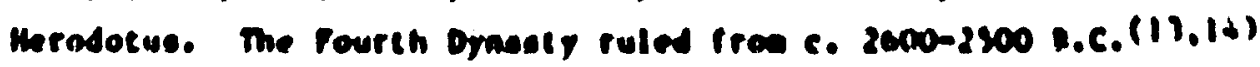

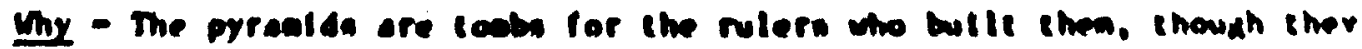

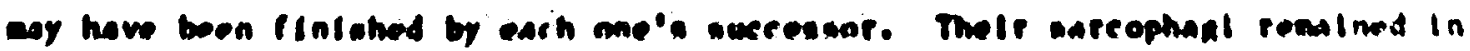

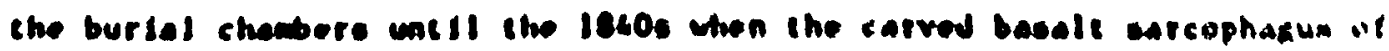

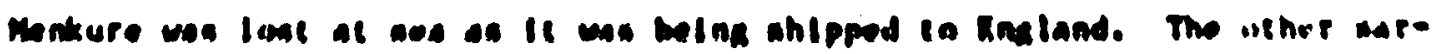

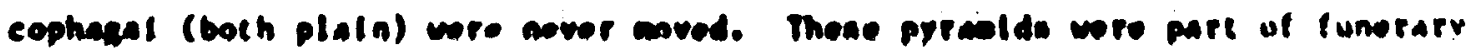

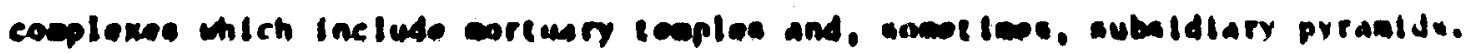

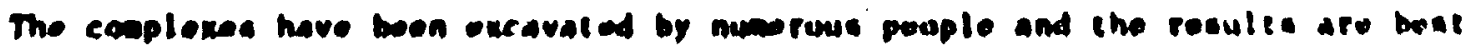
oumerted in rakhey's nort. (11)

scate of Precervation - The contentia of the tumbe were lootod In ant 1-

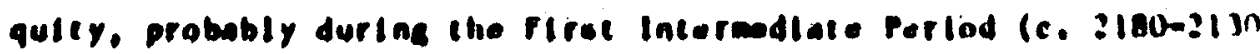
B.C.).(13) the entertar etructures are so tapresetve that they vero one of che seven wondere of the world in Rinan times and stIII are lodar. Ther have

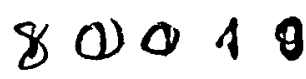


list nearly all of the casing of flner stones, and part of the cores have been quarrled, but these actions have only ade a small dent in their immense bulk. Much mor: of the mortuiry temples has been quartied away. Leaving only the lover courses of stone. The Sphinx, made of softer stone, is more heavily eroded and was repalted in ant iquity.

other Markers of the Sace Genre - The three pyrasids at Giza represent the apex of a long tradition in Egypt. The earliest pyraeld is the Step Pyraald of Sakkarah bullt for zoser (c. 2700 B.C.). (13) Thts six-layered wonuent was a sharp departure fros the prior tradition of low bench-like structures called antahas, and by the sixth century B.C. Its architect. Inhotep, wan delfied for his wisdow.

other pyranids followed (there are over 70 in Egypt). Dy the tice of snefru. II rst king of the Fourth Dymaty. the sldes were elopad. The englneere of hig pyrabid at ashur had to change the angle of the slope when they reallzed that the orlgtal desten wold have collapad the cellins of the

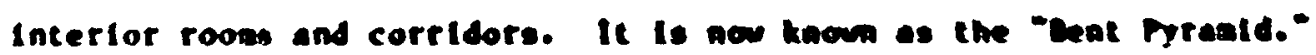

After Menkure, the pharuchs bilt weh wore wost proalde but the trad-

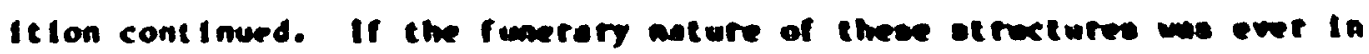

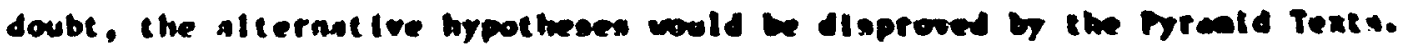

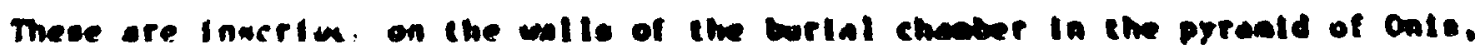
late king of the rifta byasty (c. 2330 b.6.)(13), and cecur in alt the

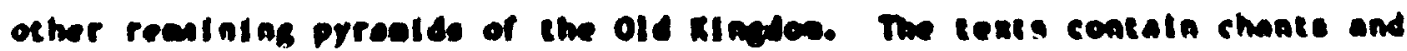

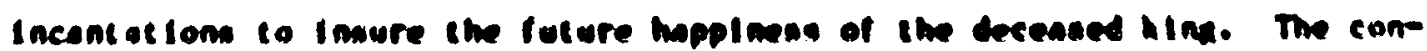

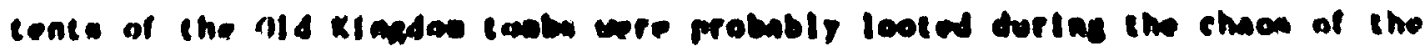

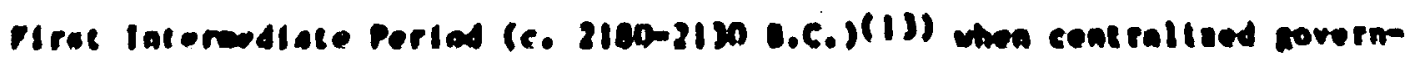

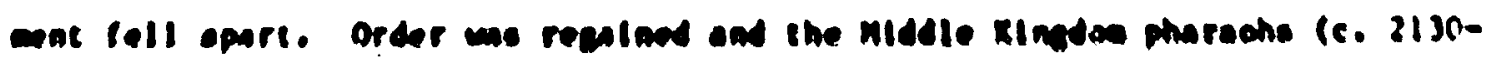

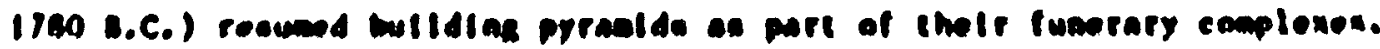

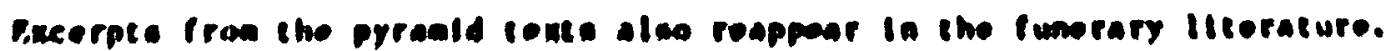

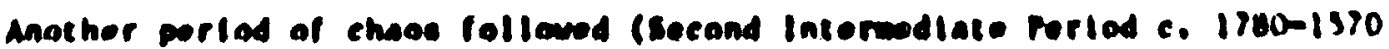

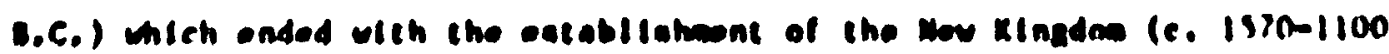

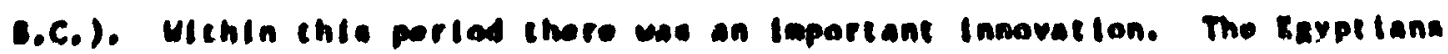

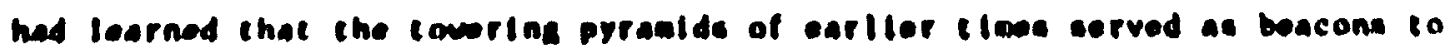

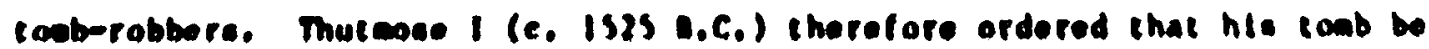
hidden and the funerary teaple be located apatt fron Il. succesalve pharaohs follewed aulits the place firet chosen by Thutanse I is now known da the laller of the kinge. Private Individuals, however, cont inued to euraiunt inetr

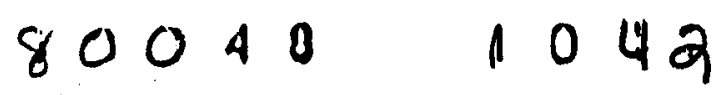


slmple tombi with sall brlck pyratids or to laclude i stele with a pyranida! cop In their tombs. $(11,15-18)$

The use of royal pyranlds was revived by Piankl (c. 720 B.C.) of the Twenty-fifth Dynasty whose capteal was In Sudan. Plankl was Inpressed by the pyraelds he saw in a llitary campalgn In the north and modeled his tomb un them. Aslde from ainor changes In form (they were sall, steep-sided, and solid). these later pyrasids differed in that they wete bullt for all meabers of the royal fanily, not just the pharaoh. Over sixty prranids occur at the - Ite of Nurl alone, wore occur at el Kurru, Lapata, and Meroe fall are located between the Third and Sixth Cataracts of the Mile). Puraald buliding In the Sudan ceased in C. 3Sn A.D. with the fall of the teroltic Kingdon wha a new religion entered the file valley. (II)

History - After It wan constructed, the history of the Sphinx Is that Thuteose IV (c. 162S B.C.) cleared the and away Irow the Sphind and bullte brick walls around it to prevent and from recencroachinge (ar thla the is was considered a reprementation of the sum and). We also erectul atele

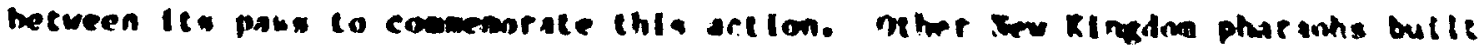
- teople or left weles or atatwes to the spmiax, as did the tings if the satte Perlod (66)-323 b.6.). (19) The flgute wuat have ben eruded hy the

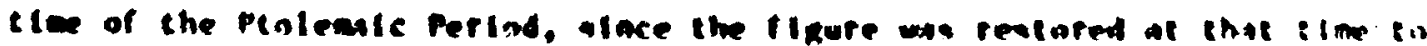

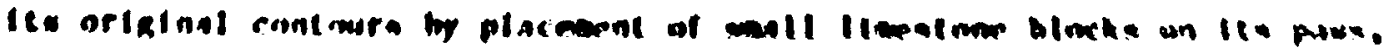

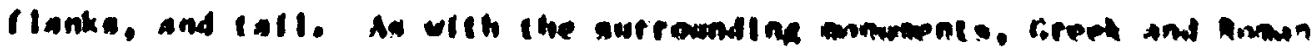

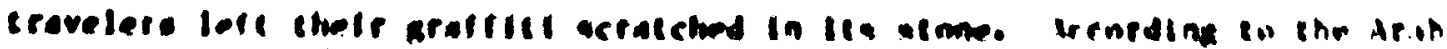

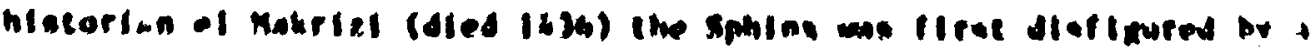

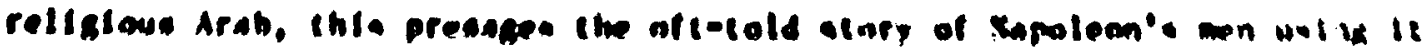

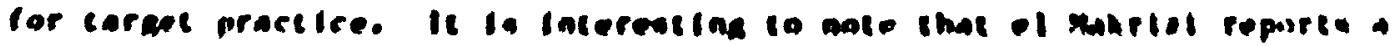

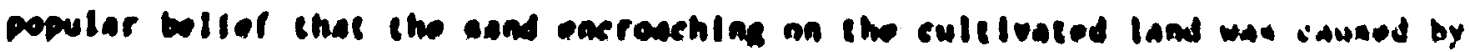
te det inuroment. $(11,19)$

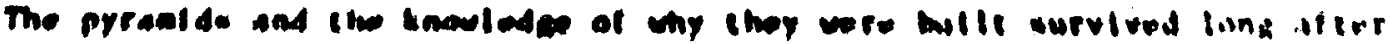

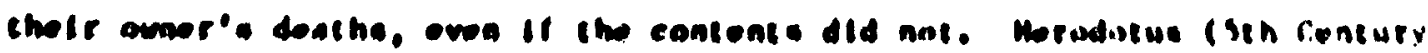

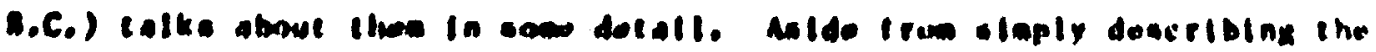

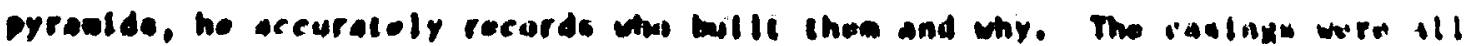

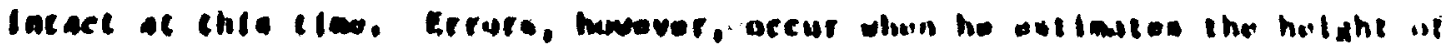

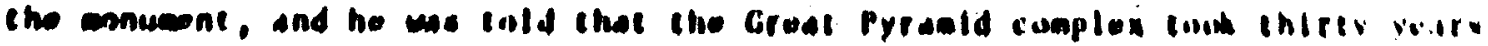

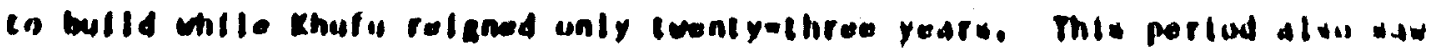

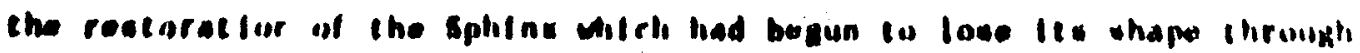
ermion. $(11,19)$ 
Diodorus stimulus (a Rosin historian) was la Egypt from bol 61357 3.C. Much of what he reports echoes Herodotus. He adds, however, that ramps were used In their construction. The remains of such a ramp occur at the Unfinished Pyramid of sorkhat (c. 2650 B.C.). (II) strabo. A conteapuraty of Diodorus Siculus, also visited Egypt and recorded that he entered the Great Pyramid. (12) pliny the Eider (23-79 A.D.), sass the pyramids but he condemned thew as an Idle and foolish exhibition of royal wealth. Pausanlus. a second century A.D. traveller, also mentioned that he saw the pyralids when he visited Egypt. (12)

By the ninth century A.D. blowing sand and debris had covered the entrance to the Great Pyralid. The son of Caliph Harun el hasid, el Matoun. forced a passageway through the amon and found late intrusive burials in the Interior. An Arab historian, Abd el Lat if (bora 1179 A.D.). went ions the numerous Inscriptions with covered the casing of the Great Pyralid. These inscriptions were lost wen the casing stones were quarried dust during and after the $13 t h$ century. There was an attempt around 120 A.D. co cot ally dismantle the Third Prrabld. but the expense of this project overutheted Ie. (11)

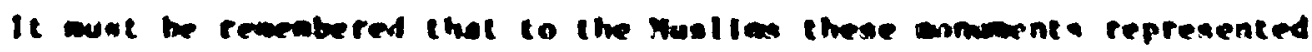
howell forces mich rohnewed had denounced, and al wo the monumpris were pagan

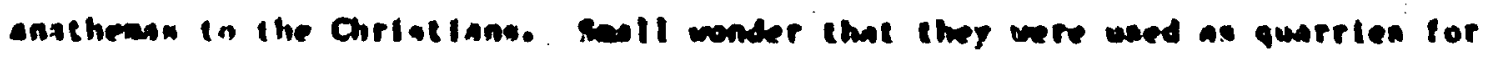

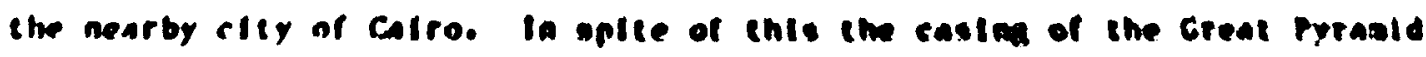

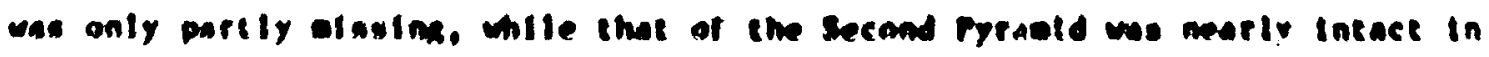

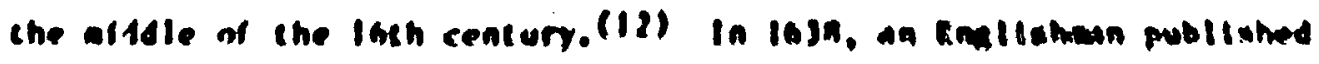

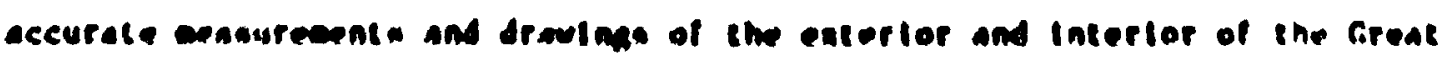

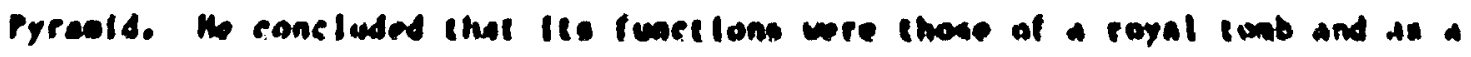

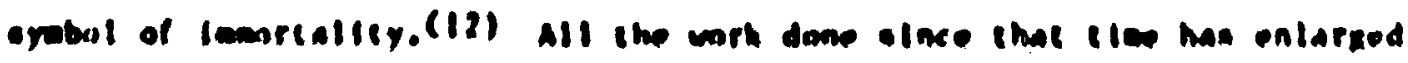

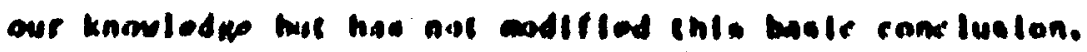

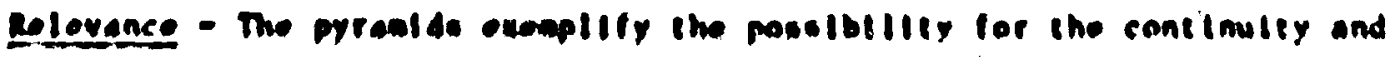

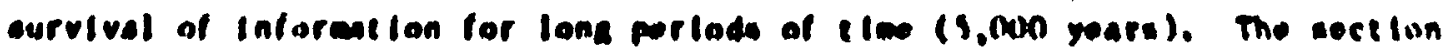

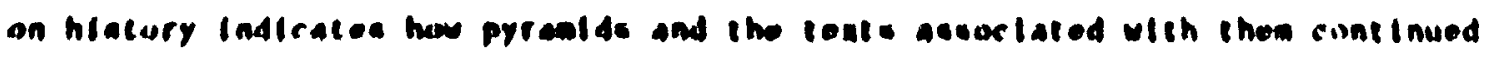

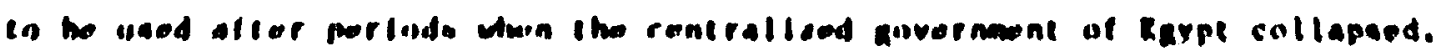

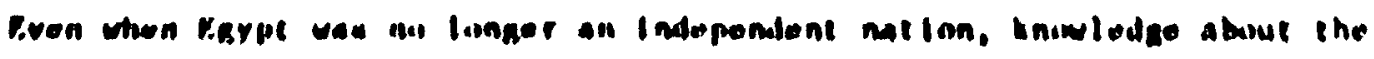

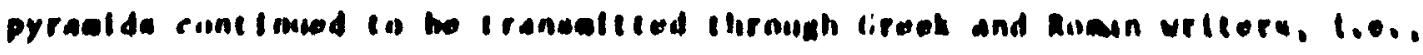

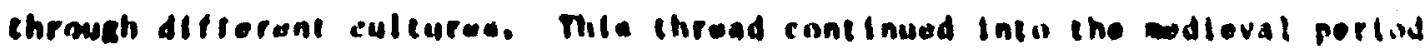
with the Arab historian, and continues with the with in Piyptolodv which is being ono today.

$800+8 \quad 10$ 내 
A second point to mike is tive importance of contemporary wricter reiorss. It 18 only by such records that we know who bullt these structures ind why they were bullt. It is the literary tradltion whith makes le pussible: ir this Information to be translated into wre conteaporary language.

The contents of the pyraids have not survived because they were linted for their intrinsic value. Most of the bullding stones, however, have reanined. Some of these vere removed, partlally because the pyramlds die located close to a large population center and te was easter to reove the stonea than to quarty new ones, but the a jority of the stones vere nos removed. So a third point to alke is that scone ay be a sutcable bediug for reposttory arkers since it is generally not valuable in and of icself. If ccone is used in the entiers, the pleces should be of sutiable slice and shape to elnivize the likilhood of belng reused In later bulldings.

A final point to ake is the aeed for tedondancy in the arker syated design. The nubber of stones used in the prtalids is 30 imense that an Intentional attempt to digmentle the sellest one (1.e. . Wenture's) was orerwheleed by the expense of the project. (II)

\section{1 .2 stomehense, Enaland}

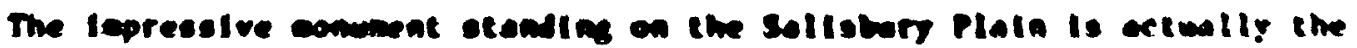

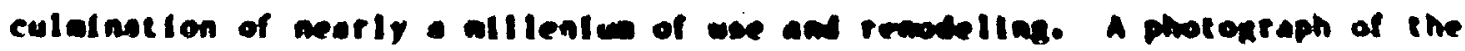

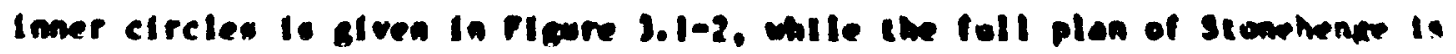

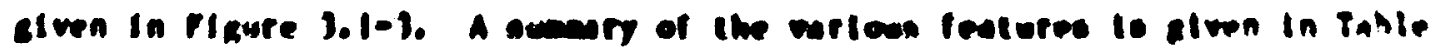

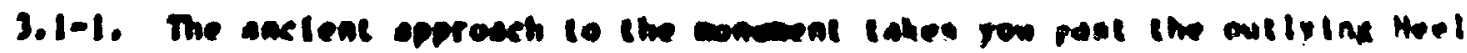

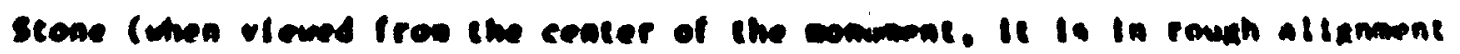

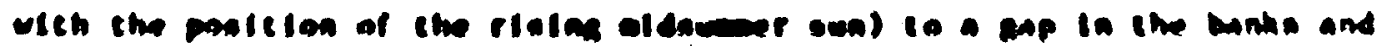

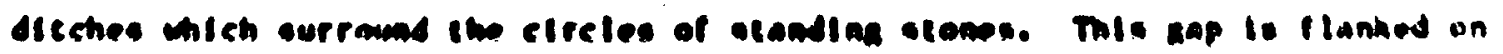

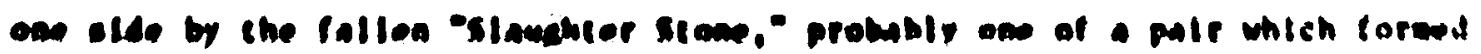

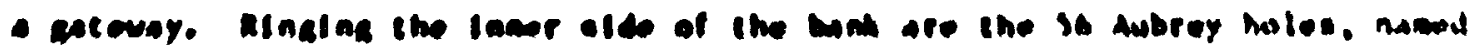

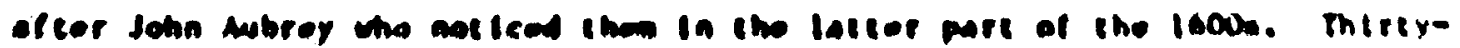

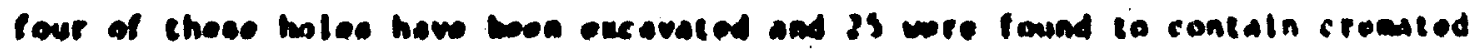

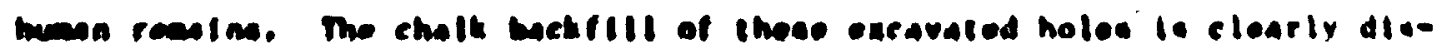
ceralble In the urase shich arom over the blie. 

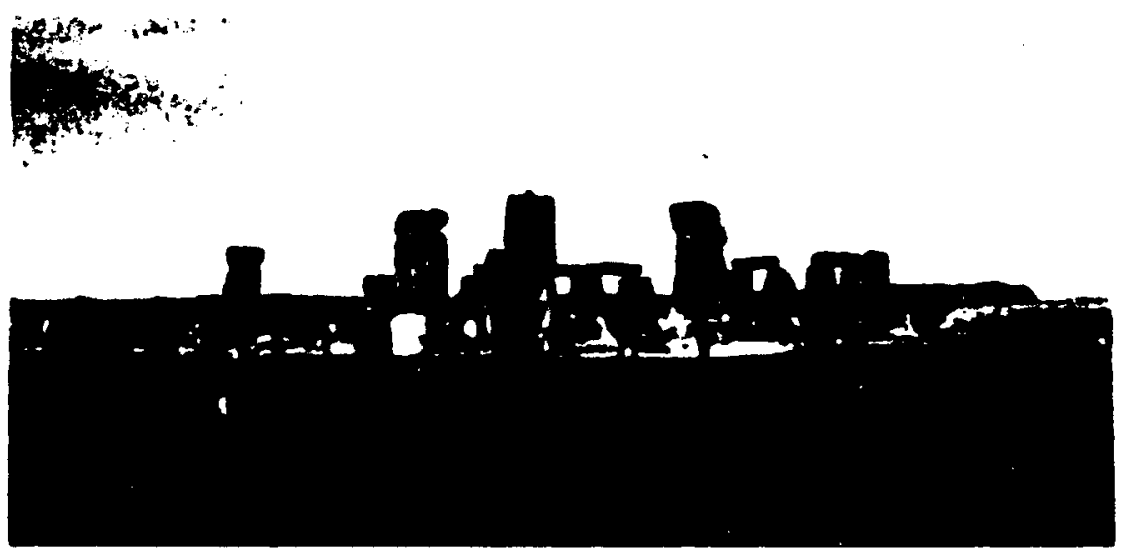

Hpure 3.1-2 Inner circles is Sivneibenge, Eaxidns

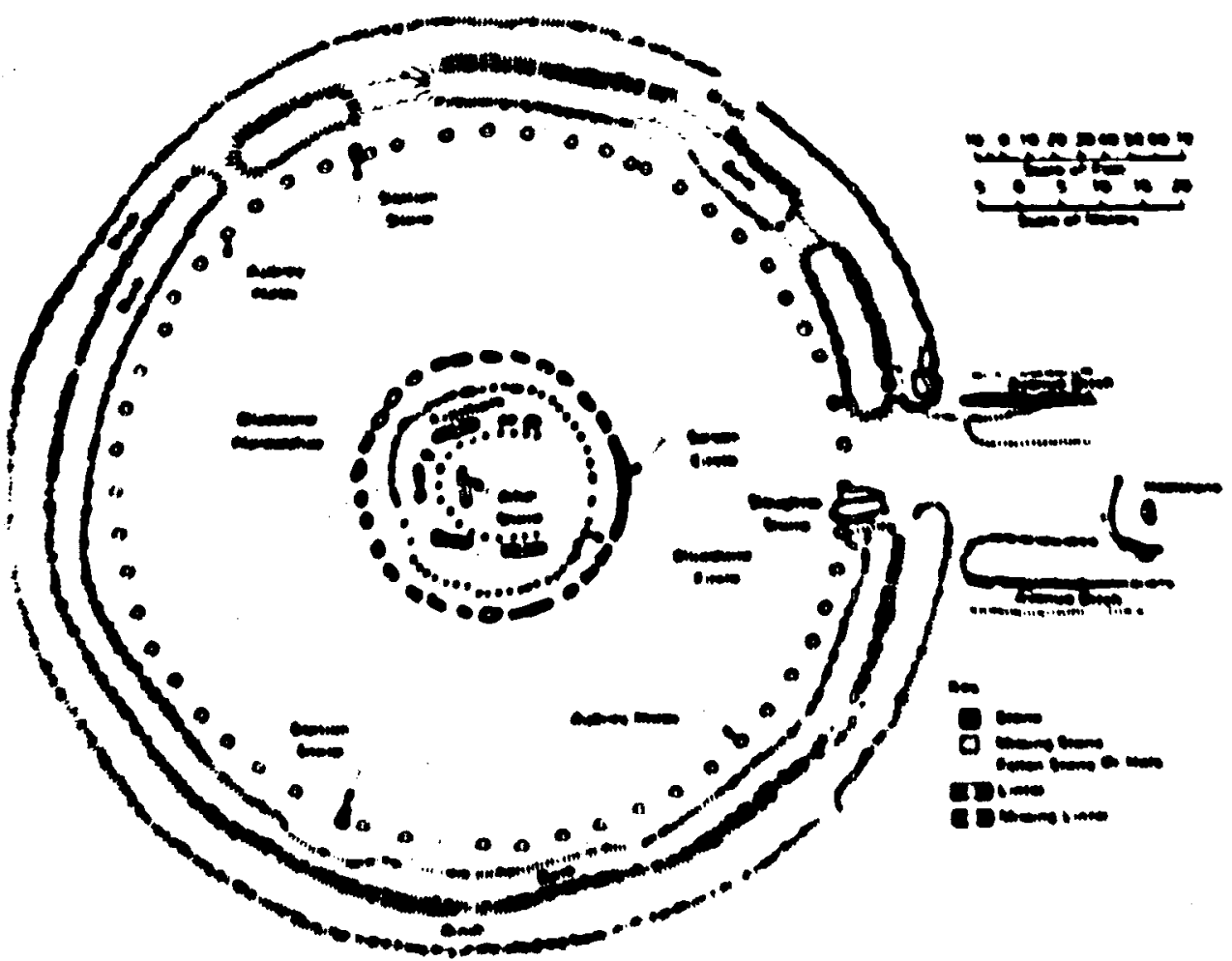

Eleuce bel-1 Plien of stonehense, lingland
$8 n 740$
10.16 
l.1.i.: $1.1-1$

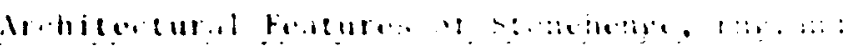

\begin{tabular}{|c|c|c|c|c|c|c|}
\hline Pesture & 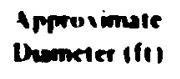 & Materiats & (omponents & Ihecentming & $\begin{array}{l}\text { Buidens } \\
\text { Phase }\end{array}$ & $\begin{array}{l}\text { Iinhte } \\
\text { Iondel }\end{array}$ \\
\hline Ooter Bunh & $: \times 1$ & Chalk & & 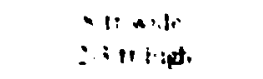 & 1 & $\checkmark$ \\
\hline Imenth & 2411 & & & 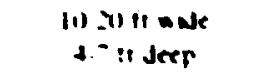 & $\mathbf{I}$ & W \\
\hline Inmer Bank & $\because \because$ & Thoit & & $\begin{array}{l}\text { intrandi } \\
\text { orit hath }\end{array}$ & 1 & ra \\
\hline Rme & $: N_{1}$ & Choll f flled & 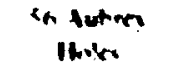 & $\begin{array}{l}\text { :A il }=\text { wh } \\
\text { is is dert }\end{array}$ & I & Ie. \\
\hline Satuw Mitum & & Suren & 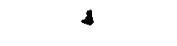 & I. Wh hate & $\mathbf{I}$ & : marone \\
\hline Itael binger & & Sut wen & 1 & 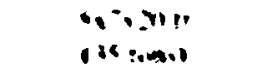 & 1 & Vi: \\
\hline Kmp & Ine! & Surm & 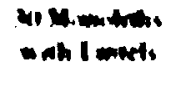 & 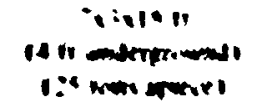 & III & $\begin{array}{l}\text { 10 Imen: } \\
\text { Imeiv } \\
\text { venne }\end{array}$ \\
\hline Rme & 4 & Blucuiter & Chat & 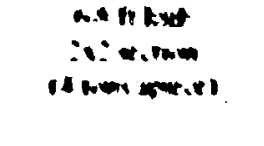 & m & 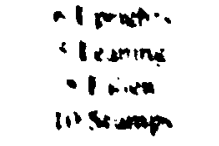 \\
\hline Deroestiox & & Imen & "Irvinturins & 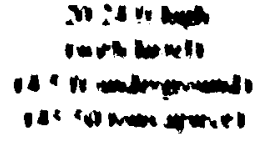 & III & 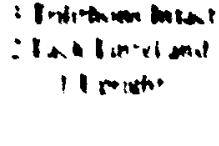 \\
\hline Ahnordune & & Atherestors & is thencinst & 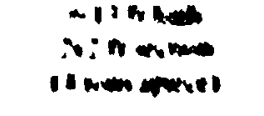 & at & on..... \\
\hline Sumpret Momp & & serent & 1 & $41,: 10$ & mil & Inten \\
\hline Anen Nenew & & Preteram & 1 & $11: 1.0,16 n$ & IIII & 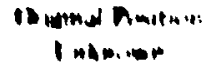 \\
\hline
\end{tabular}

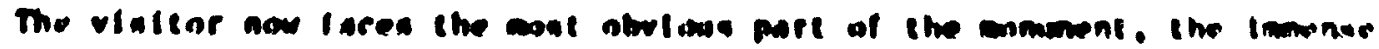

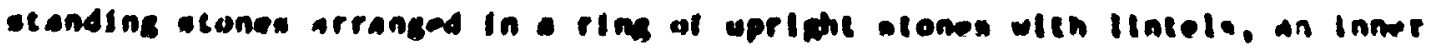

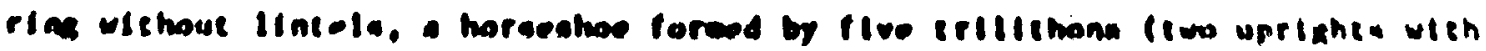

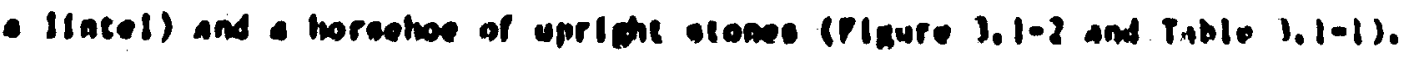

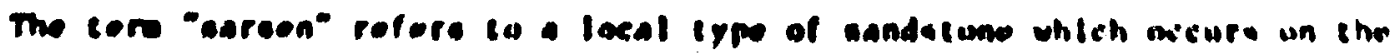

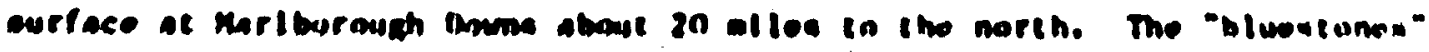

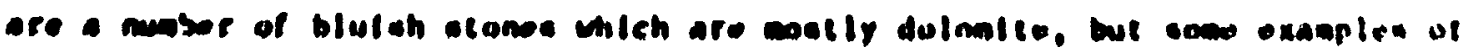

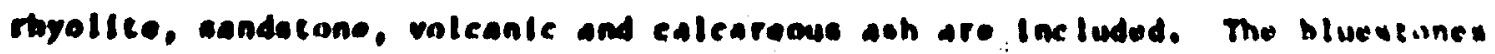
anly oceur cogother in a canll ared (about ane alle square) in ihe Proncelly

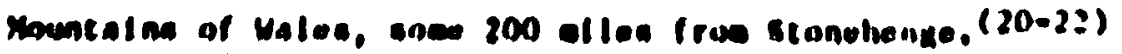

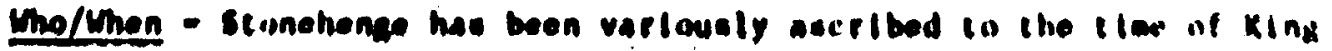

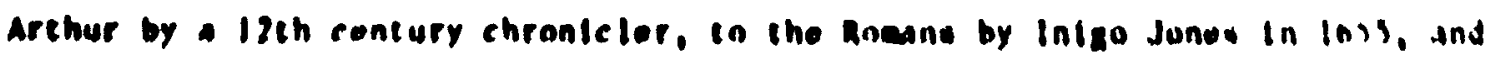

$$
80010 \quad 101 \%
$$


to the Drulds in 17\$0.(22) Around 1900, the suggestion that Bronze Age Brttalns hutlt stonchenge was put forth, and that is the theory now dicepted by most histortans.

The quextion of who bult stonehenge was settles long before the gilestion of when it was butlt. The re-callbration of carbun-1: dates has creited $\mathrm{A}$ revolution in European prehistory, (23) and places Stonehenge as $x$ conteaporary of the pyramids of fegypt. Bulldiag at Stonehenge began $\therefore$. 27.tib25, i B.C., and the fIrat bullding phase included the ditch and hanka. the Aubury holes, and the Herl Stonc. It also ay have Included the Stat Ion Stonea.

The min change In milling Mase It was the cransport and erection of the Iaported bluestones in two concentric circles. This tmok place c. Ilixo B.C. but wan never finished. Instead, the bluestones were rewored and the circle and horseshoe of arsen atones were ralsed (thase IIIa). Finally. the bluestones also were arranged in a horacshoe and circle (Phase titis). The later work wan done c. $2100-1900$ B.C. $(20,23)$

Why - The allgnment of the Heel stone with the aldsunger suntine was firet noted by stucketey in 17bo. mowerer, It was not ont II the lomb that further astronomical uses of the monweat were hypothesteed and tested: this was the work of Mamins. $(22,24,23)$ This work drev great protest, particur Lerly from Atkinmon, the excevator of the ste, $(2 n, 26,27)$ we it is now generally accepted that the critithons were used In following the mitions of

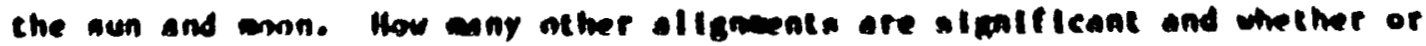

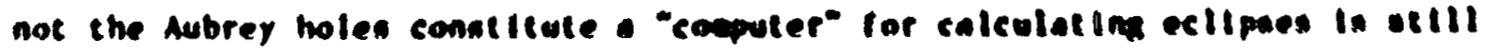
- enceer of debate. (23,2h-31)

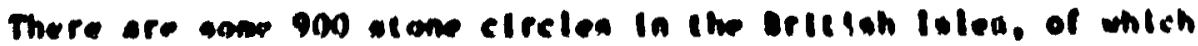

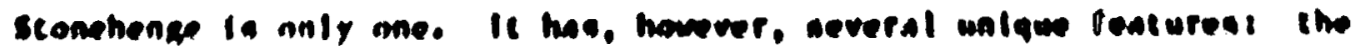

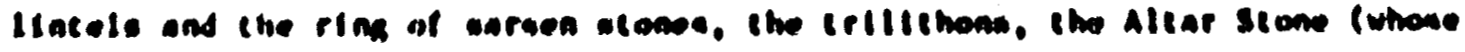

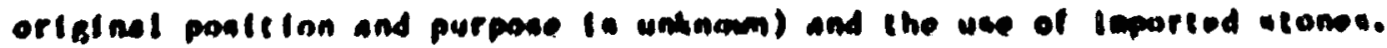

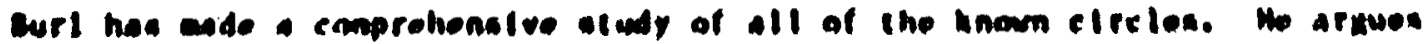

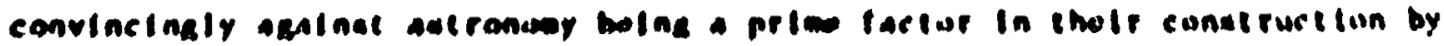

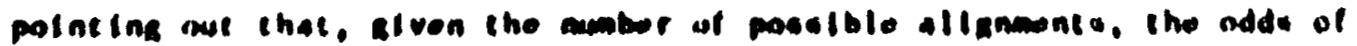

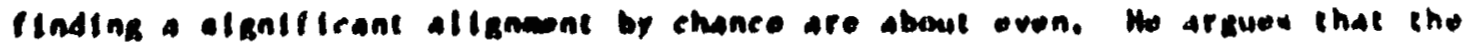
aecronatral function of the ring was only part of lis purpuse as a ritual encloaute for portadle pathering and comments. "another difficulty is tho entere abeence of urition recorde that could confirm tho astronualcal

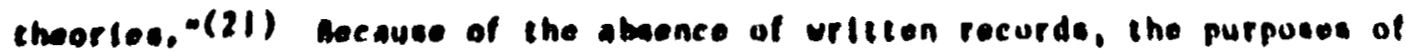
these econe ringe etlll are being debated.

$80040 \quad 1048$




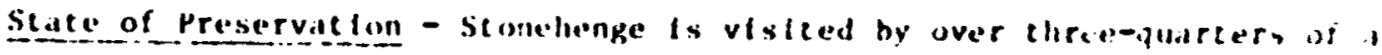
wilion people per vear, and rupes now protect the bank and ditch from obliteration. (21) The monument, however, has survived while Britili hil undergone Iavaslons (in SS B.C., 48 A.D., and lohn ..D.), the Inierne-ine wirs of the Roses (1455-1485 A.D.), and the two horld wars. By the Isin)s, with the rise of Romanticisw, the monume was auch vistied, and haserers were rented to courtsta for the purpose of chipping of are not easily demolished. As may be seen from Table $3,1-1$ and Flqures $3.1-2$ and 3.1-3, about one-half to two-third of the uprigh: stones survive and remain In position. Several of the stones had flgures carred upon thea in the Bronze Age, and these way be seen today.

other Markers of the Sace Cenre - As ment loned above, stonehenge is but one of many stone circles. Wurl has complled data on sowe 963 stone clecles wich occur in the British isles, Ireland, and stitcany and inls discussion leana heavily on hio work. (21) two-thitds of these clccles are preserved well enough to entiante their diancter: these range fros under 9 is av over 200 ft with over half of the examien falling between in and w) It. The site of Arebury contalna a dich nearly nnequaster of a olle in diaceter (Iino it)

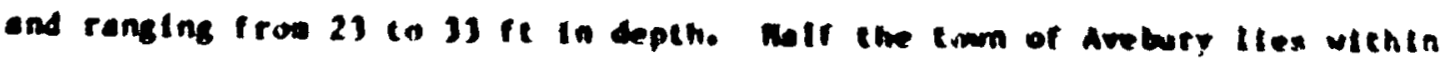
1t. The large megalithic ring instde the dich in the largest in ine orition It lee with a disecer of $345 \mathrm{ft}$.

ruch effors has been expended is mesuring was reportint the pratition of

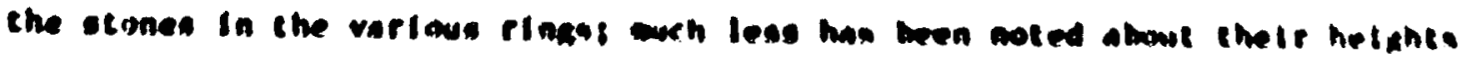

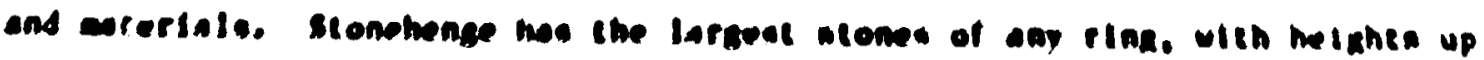

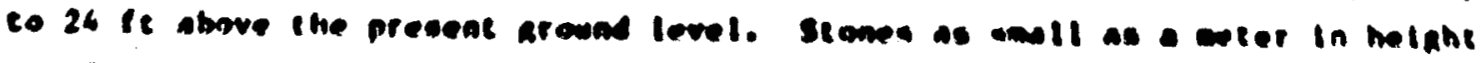

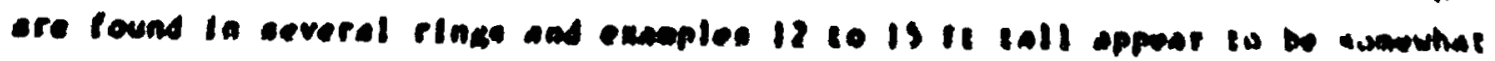

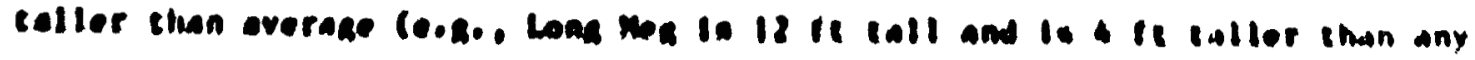

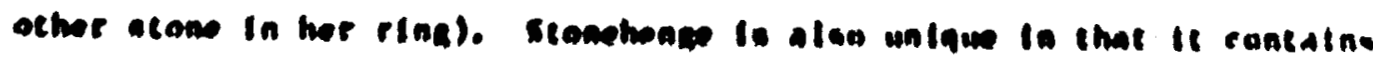

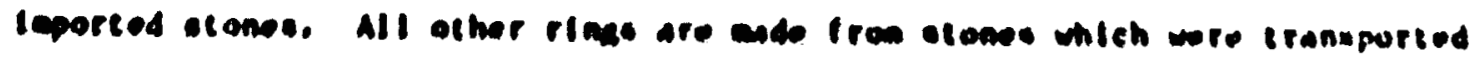

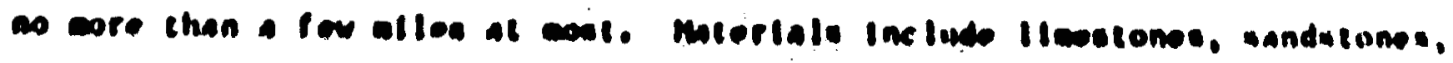

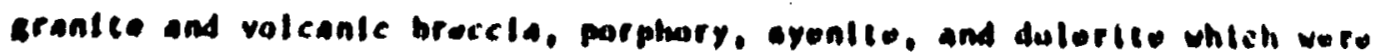

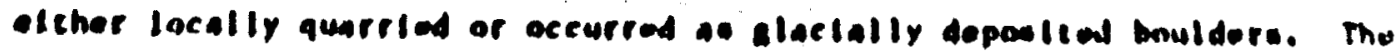

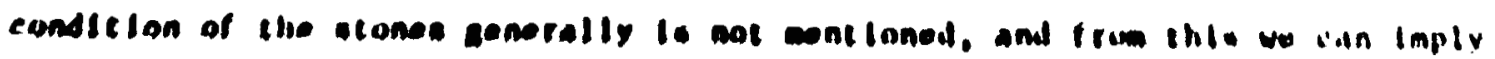
that they aro weIll falply sound. The moltright stones are an excoption,and

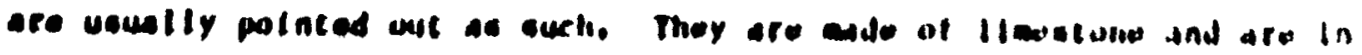
trapontary andition, (21) 
History - Stonehenge, per se, has been written about since the IItii century A.D., and has becore well-enough ensconced in publlc kiowladge to appear In many literary works including those by Wordsworth and Hardy. (22) An earlier reference (Ist century B.C.) any occur In Diodorus Siculus (History, Bnok $V$ ), but no nase $1 \mathrm{~s}$ given and the attribution of thls passage in Stonehenge is therefore debatable. (20) It is interesting to note that Geoffry of Monmouth (c. 1136) telis of Meriln saying "send for the Glant's Ring in Ireland", when the stones actually originated in Wales. The quiry site ay lie on the trade route from that part of England to Ireland, but the oral tradition, though reweabering that the stones vere loported, has the wrong place of origin. Ceoffrey also relates that the momment was erected (by Herlin at KIng Arthur's request) for conmeworating sone slaln nobles, but says nothing about its ascronoalcal purpose. $(20,32)$

The wonument cont 1 mued to be know as a "speclal place*. though the exact nature of the place 18 stIII debated. Mis debste extends to the other stone rligs as well. The spectal nature of these tings and the Influence they had upon the local population was atcer of great coacern to the early Christian church. The edicts of Arles $(432$ A.0.). Tours (367 A.D.). Kantes (658 A.0.) and Toledo (6BI A.D.) exhort the locel blshops and clergy in destroy "those

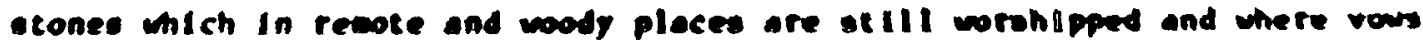
are st111 ede*.(33) The deatruction or topplias of stenes seen in the ringe ay be the result of these edtets and inter atimple to wipe out the Influsnce of these pagas momesata.

Many of the riags ourvitud these atechs. They ay have done so because

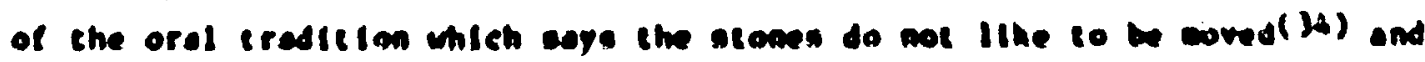

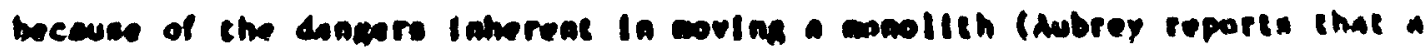

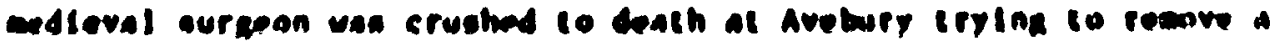

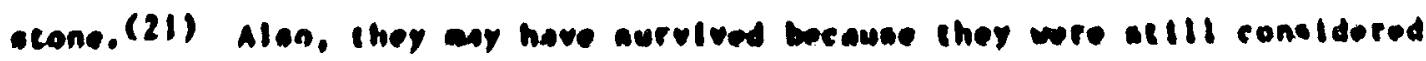

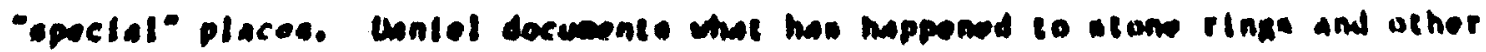

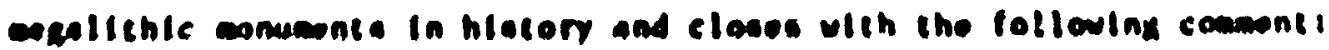

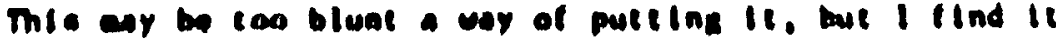

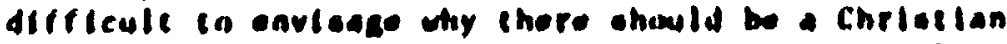

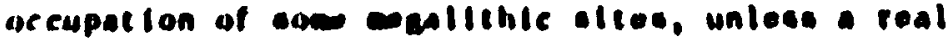
cradition of thate laporiance as spectal and ancrod places we carfied througli tho porlud of the arunae

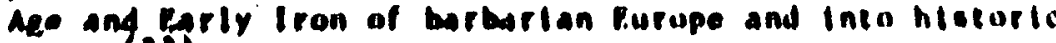
$100 .(3)$

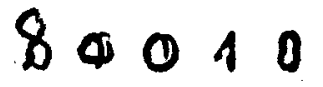


Relevance - Stonelienge is a prime example of the difflculties ensinntered in marking a site with only level I Information. It must be enphaslzed thi: the purpose of Stonehenge and the other stone rings is still being debdted because of the "entire absence of urltten records that could confirm the astronoulcal theories". (21) it Is this absence of wrlicen records which nut only obscured the purpose of stonehenge, bit even the tiaes when the vartous parts of it were constructed. That Stonehenge Is a conteaporary of the Egyptian pyrasids was known only after the Introduction of carbon-li dasing.

The history of stonehenge points out the mossible corruption in Inforation conveyed by oral tradition. Though the nedieval chronlcle recurds the tradition that the stnnes are inported, te has the urong place of origin.

The plan of stonehenge and of the stome rlogs in general war be rery useful for reposttory arting syste design. The use of cultiple components weans that the plan of the area can be reconstructed even though snas of the componentw have been lows. Stomehenge has lost approximately ome-third of lte stones, yet there Is no debate about its plan. For the other tings, with mich saller compnent, some bon still gurvive well enmugh in eatiace thels diameters. It appearn that redundancy in the monbef of compmnents wapd to

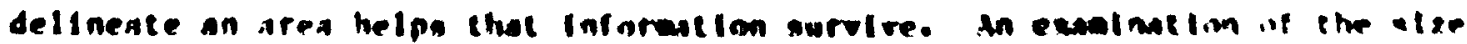

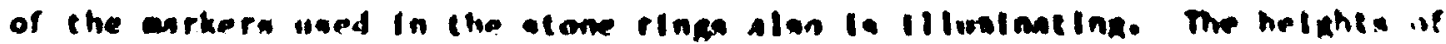

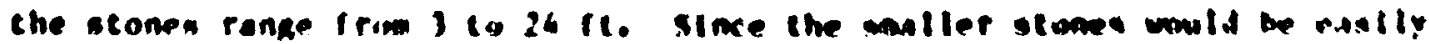

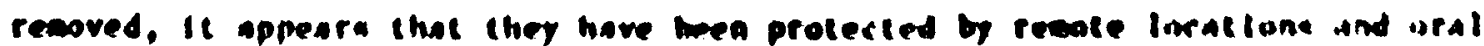

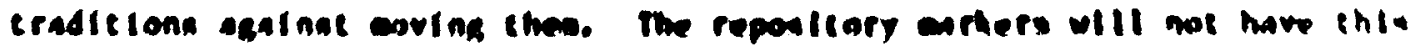

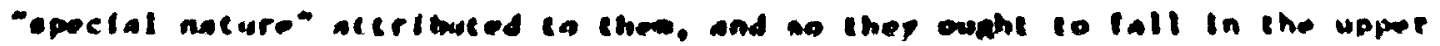

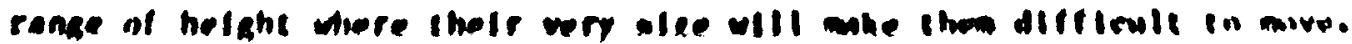

\subsubsection{Nazen Linoe, Pera}

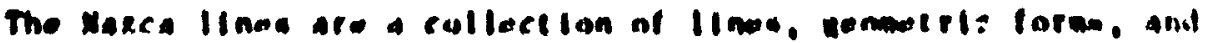

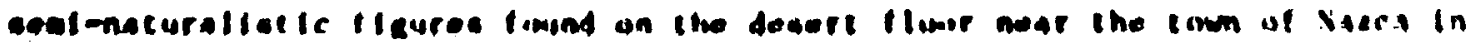

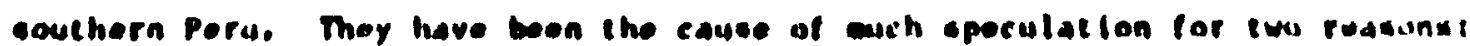

- They aro much eure viathle from the alf than on the eround.

- They are draun on an enoramus acale. Vor example, ono larde cloarod

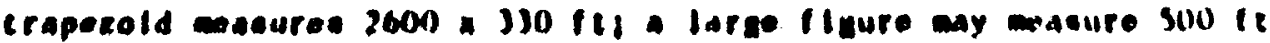
in lengelif and alngle linos any run are ihan 6.5 atlos in lengeh, (13) 
The lines (actually paths about $2 \mathrm{ft}$ wide) are made posslble by a set if geological circusistances. Wind eroston across the desert tlour carried ot the dusty surface soll, leaving behind a "pavement" of pebbles and boulders. Over time these stones develop what 18 known as "desert varnish," a brownish-black coating of tron and anganese oxides formed by che in situ decomposition of rock and the depostition of oxides upon the surtaces by capillary action. The rate of tomation of this varnish is very slow, and aay have begun as far back as the Pleistocene period. The underlying soll. however, resained pale in color. Plcking up stone will expose the light-colored soll underneath it. Picking up row of stones will create a IIght-colored line.(35)

who/when - The answers to the questions of tho drev the lines on thls patural blackboard, as wil as when and why they were dran are not definitely known. The figures dram on the desert lloor (conkey, Ilserd, epider, trophybearing killet wale, etc.) find parallels in kace wires, a distinctive type of pottery wich dates from about 200 B.C. to 600 A.O. The elalletity led to the concluston that the seme population was responible for both cteations. In addition, is percent of the poteherde collected on the devert floor by

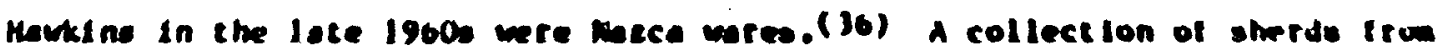

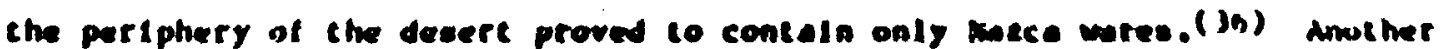
tym of evidence is the carbon-14 date obtelined tros poet wich uns apt at the Intersection of two liaes, and gave date of siv A.D. 1 wo

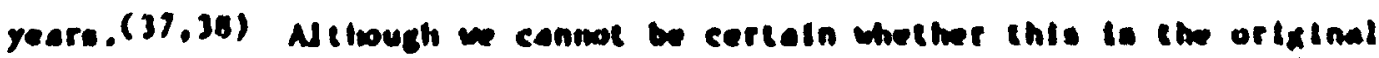

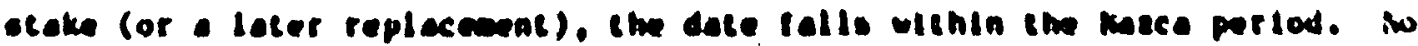

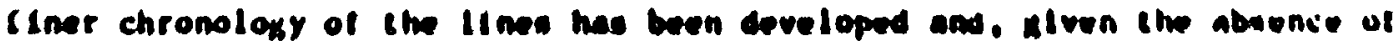

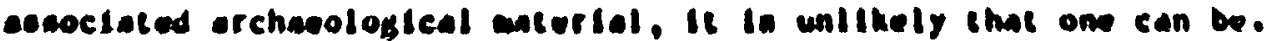

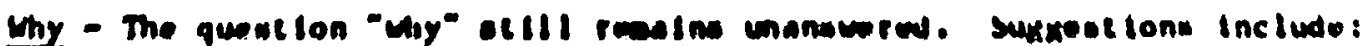

- Anceonoulcal atgheting Itano $(39,40)$

- Pictures ces be viend by the gade of tho aky(4)

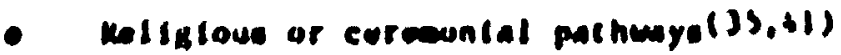

- Mechantas ea bilance the rasustece and population. (Jo)

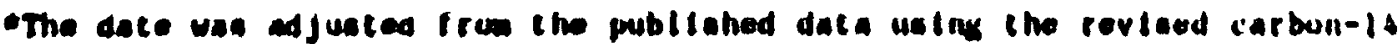
half-itic of 3734 yeurs and the mach recalibration curve. 
One of those suggest tons cin be eliminated. Gawklns tested the hypotheris of astronorical sighting lines by accurately surveylng them and us: np a computer to check the allgnonts as he did wth stonchenge. The lines cinnist ho. us.et physlcally to slght stars, and 80 percent of the lines lick iny semblarer i: solar or lunar alignment. (35) As for the remaintng sugkestions, there is Insuffictent evidence to elther confirm or dony any of them and so the lines remain a mystery. $(42,43)$

State of Preservation - The lines were made posstble by a particular set of ctrcunstances. They were preserved, In part, hecause of a very low local erosion rate. They have also been preserved because of theit reoste location (the area Is too arid to support a peranent population). and the fact chat the area was depopulated shortly after the Spanlsh conquest. The IInes are a fraglle phenowenon and undergo rapld degradation when people drive or walk over thee In order to see thew. A photographic esaly by McIntyre(th) Includes a photograph which shows the destruction undergone by one flgure in only twelve years.

Other Markers of the Sabe Cenre - Anclent antings of this nort occur in nunerous places other than Masca. Peru. Howling(35) estiates that there wy have been s0-10n such stes In Perv alone. Sortison wentions sites in Chile and Bolivia.(41) over fifty drawnge foracd ts the eace techniqime occur in Callfornta and Artzona, (45) though the ages of these figures are not known. As with the nacce acertal, wost of these realins oppear to have survived because of thetr remote location and sultable cllatis conditions.

History - The figures were brought co the atsention of the seneral wurld ta the late 1940, by kosok. shough they were hown before on a locel level. (18)

Ralevance - The wece Itme ore en emaple of the polential curvivability

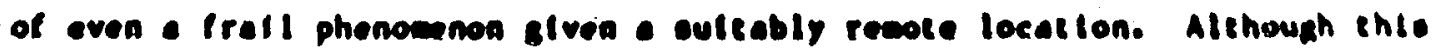
elfect cennor be quanelfled. the reqealeory wII also bo located in an area

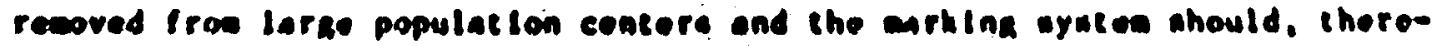
lore, have alellar incroies in aurviviblitiy.

Agalo we the inpartance of urtesen records ta the understanding of

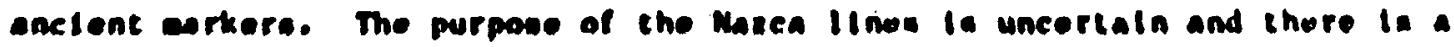

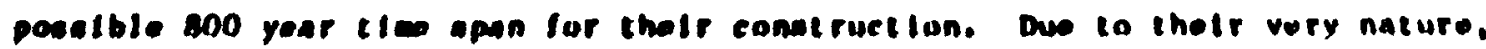

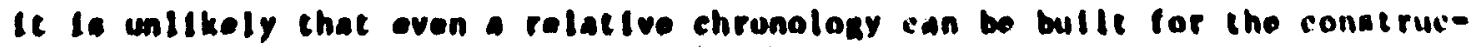

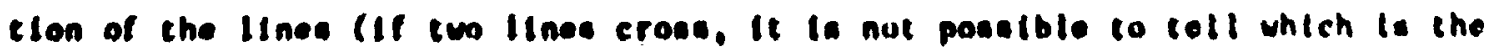
80048
$\begin{array}{llll}1 & 0 & 3 & 3\end{array}$ 
earlier). This lack of knowledge is due, In a large part, to the absence of contemporary written information about the culture whlch made che lines.

Finally, although these lines are clearly visible fros the alr, they are difficult to track on the ground. In contrast, a repository arkink syster should primarily stress ground visibllity.

\section{1 .4 Serpent Mound, Oh10}

The Serpent Mound is an eabankeent of earth in the form of a serpent in the act of uncolling (F1gure 3.1-4). In Its present state of rescoration. the serpent consists of two parte, the serpent proper and the oval shape. The latter has diaweters of 125 and $60 \mathrm{ft}$ and $1 \mathrm{~s}$ t fe high. A sall wound of burned stones lies in the center of the oval. The length of the serpent proper $101254 \mathrm{ft}$. The colla and convolutions, hovever. fit within an arc that is $737 \mathrm{ft}$ long. The average width of the body is $20 \mathrm{ft}$. The helght is

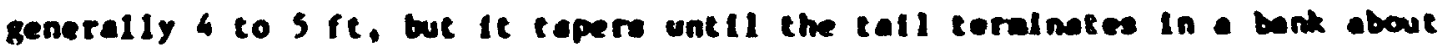
I ft high and 2 fe wide.

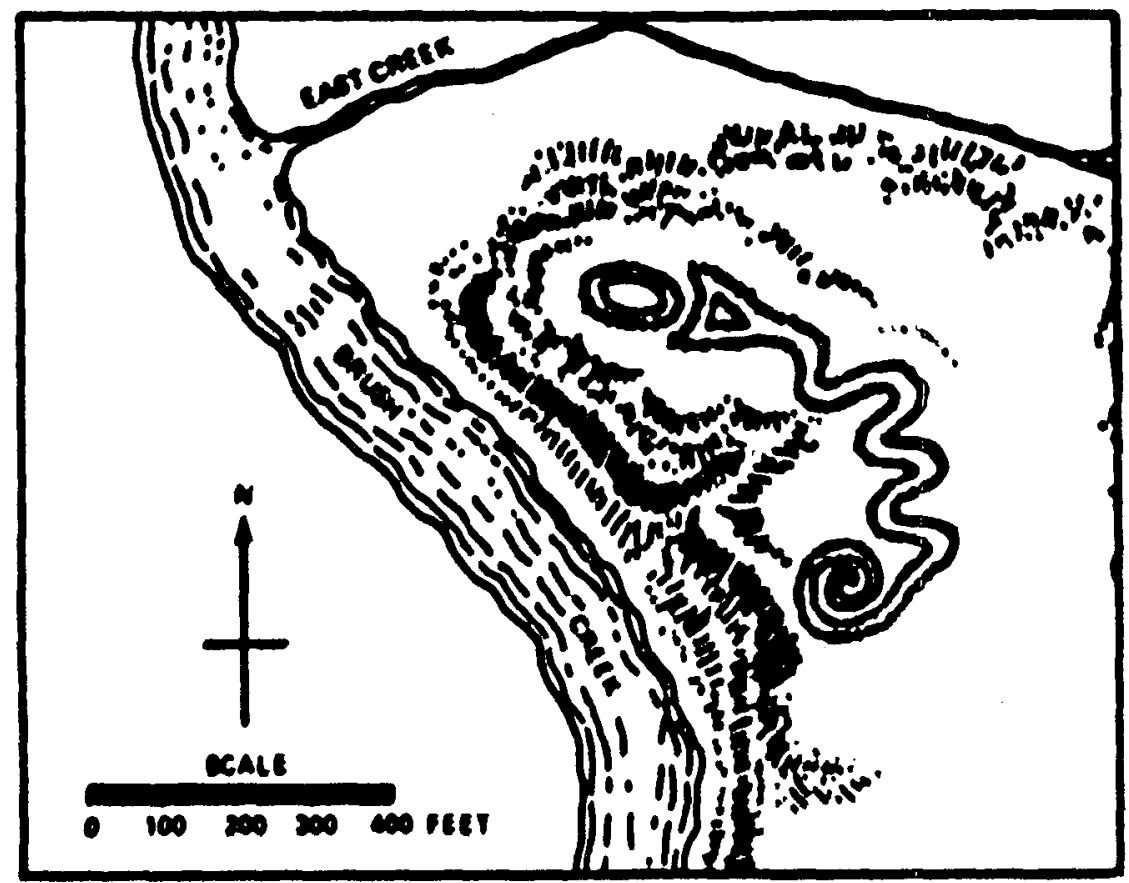

PIrure 3.1-4 Berpent Mound

$8714010 ! 4$


The serpent was formed by blucking out the pattern with stones ins. liy. On top of the stone cure a foot thlck layer of clay was added. Ahive thls lies a 2 f layer of dark soll. (46)

Who/when - in artifacts were fmand in the excavation of thls aonument. There 1\%, however, a butal mound withla 400 it of the serpent. The artifacts found In this wond belong to the Adena Indians who lited in ohlo between limo B.C. and 700 A.D. It is generdily accepted that the mirlal bound ind the Serpent Mound were bullt by the sabe people. $(66,+7)$

Why - The purpose of the wound is stlll hot knum. Stace it is obvisusIy In the form of a serpent, most Interpretatloas use the role that cretture played in Indian aythologies and rellglons as bists for their hypotheses.

It should be noted that there are several Interpretatlons of the figure. These differences are due to differeaces In Interpreting Irtekular features on the ground. The fom of the serment and the oval shope have teen qulte tear. and these are Identically shmm in all the drowinge. It is the features beyond the oval and to the stes of the meck wich are in alsmule. Me earliest

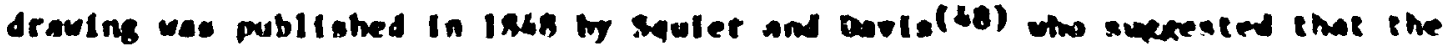

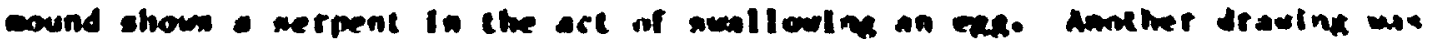

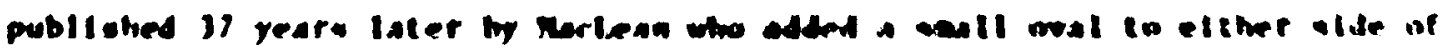

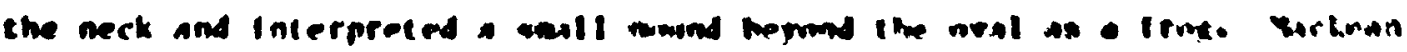

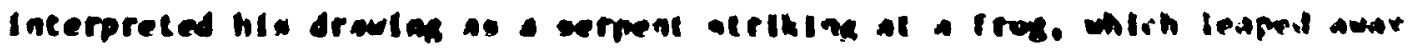

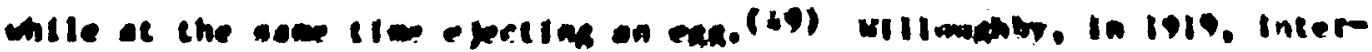

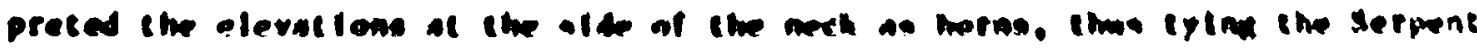

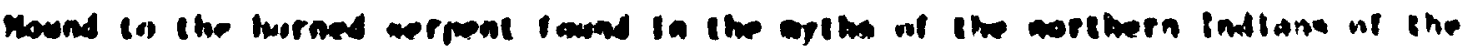

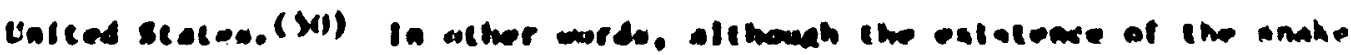

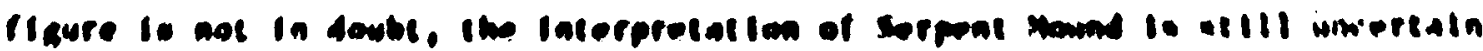
and sompruse notmolane.

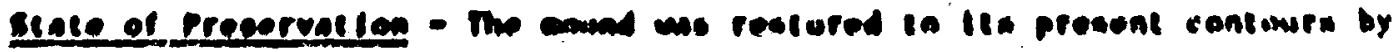

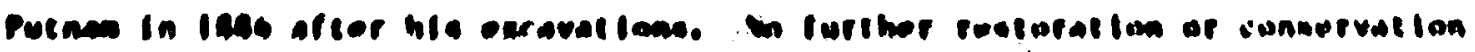

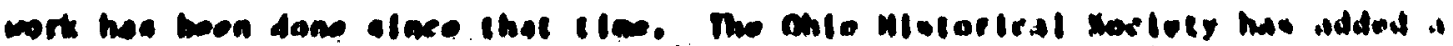

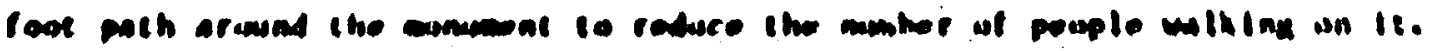

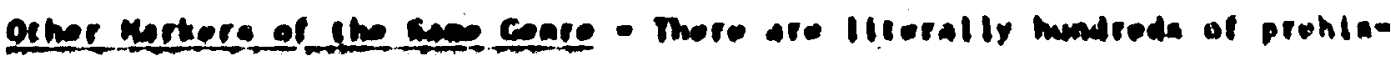

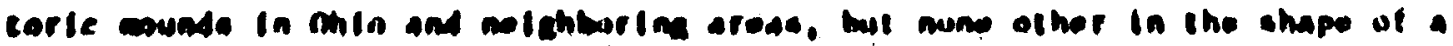

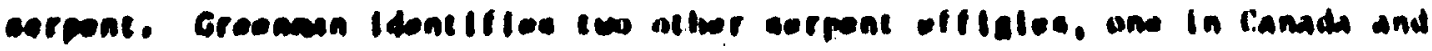

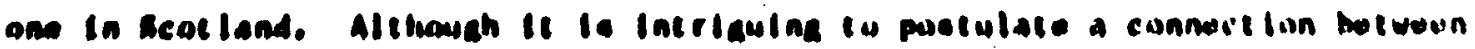

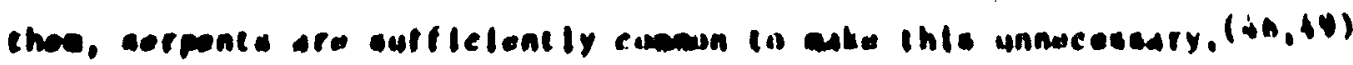


The serpent was formed by blocking out the patcern with simes ind ily. On top of the stone cure a foot thick layer nt iliy was idled. Ahuse this lies a $2 \mathrm{ft}$ layer of dark sill 1 (46)

Who/ When - iv artifacts were found In the excavitlon of this somument. There is, however, a burlal mound within 400 it of the serpent. The irtifacts found in this mound belong to the Adena Indlans who lived in ohfo beeween limo B.C. and 700 A.D. It 18 generally accepted that the hurlal mound ins the Serpent Mound were bullt by the same people. $(4 h, 47)$

Why - The purpose of the mound is still not known. Stace it is obvisusly in the forw of a serpent, most interpretations use the role that creature played in Indian mythologies and religlons as a bists for their hypotheses.

It should be noted that thete are several Incerpretations of the figure. These differences are due to differences in interpreting irregulur fedtures on the ground. The form of the serment and the oval shape have been quiter ileat. and these are Ident lcally shmen In all the drawings. It Is the festures beyond the oval and to the sides of the meck which are in dispute. The earlitest drawing was published in 1 k4h by squler and Davla(to) who sughested that the mound shows a serpent in the art of suallowing an erke Another drating wis

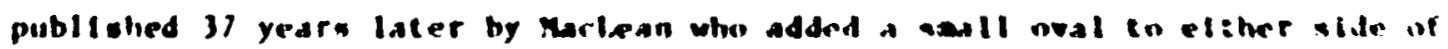

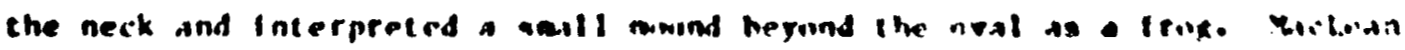

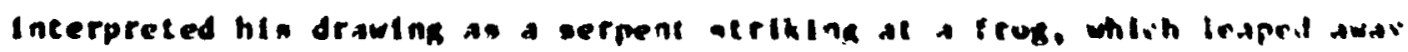

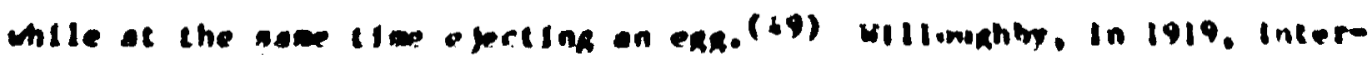
preted the alevations at the alde of the nech as horns. thwa ty ing ine serpent Hound is tlie lourned werpene tound in the aythe of the northern indtane of thr

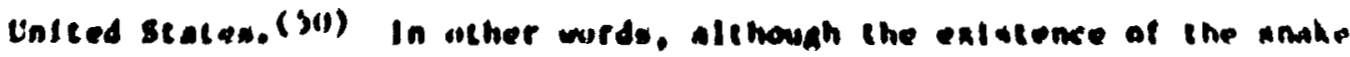

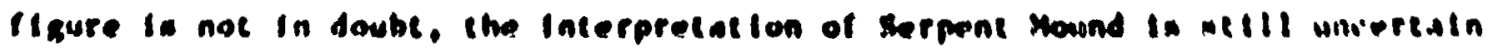
and sompunge nobulous.

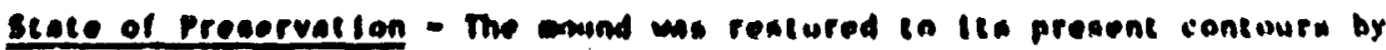

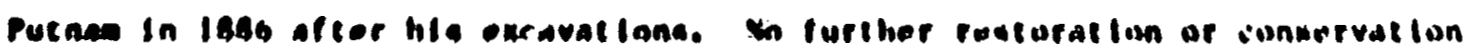

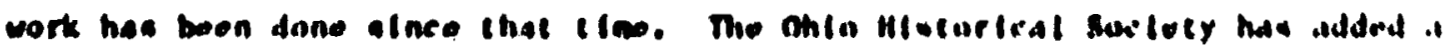

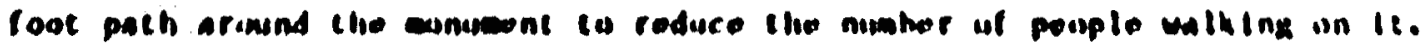

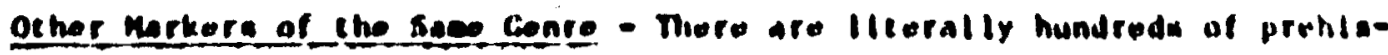

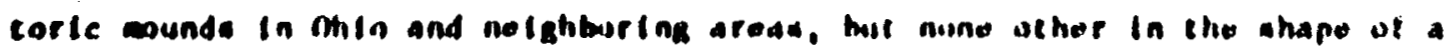

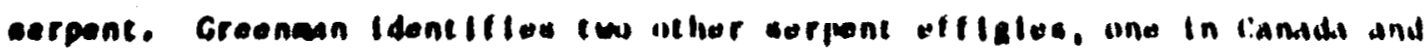

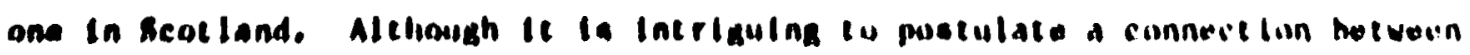

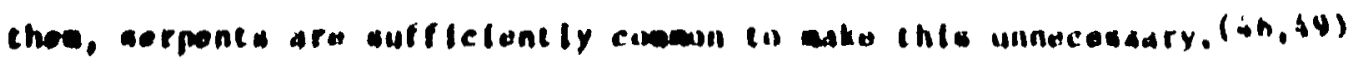
80010
$10: 6$ 
discussed by Travlos(SI) and the other refetences cited therein. A general photograph of the Acropolis is given in figure 3.1-5, whlle a plan of the wonuments discussed here is shown in Pigure 3.1-6.

Beule bate - As you approach the Acropolis, the first ceretonial entrance you reach is the Beule cate. An Inscription on the monument tells us that it was pald for by F. Septiaus Marcellinus and bullt c. 260 A.U. The two pylons are plerced by a gate wich is aligned with the central opening of the Propylaia. It is bullt of livestone and the blocks were taken tron an earlier coment wich dates to c. 310 B.C.(52)

Agrippe Monuent - The Agrippa honuent stands on a natural terrace between the beule Gate and the Propyla1a. The sab for the atatue etands 29 ft high, was ade of arble, and originally bore four-borse charlot. Inscription on the slab tell ue that the lateat etatue we raleed co harcue Agrippa In 27 B.C., wile the original group was dedicated to celebrate a charlot victory by the city of Pergeon in the rasathenalc Cues in c. 178 B.C. We know froe the witinge of Platarch and Dio Cassiwe, that the elab once bore etatues of Aathony and Cleopatra. bet these blew dom in 31 .6.6(52)

Propriale - The rropylata is the clacetcal gatemy to the Acropolis. and 1. pert of the overall womentel rebullates of the olte vadertaken by

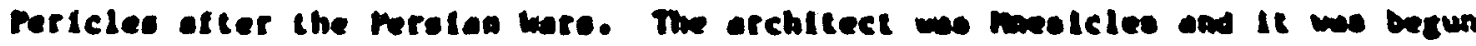

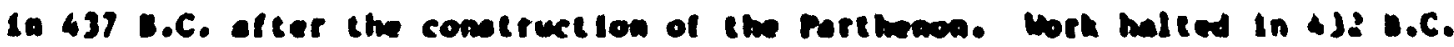

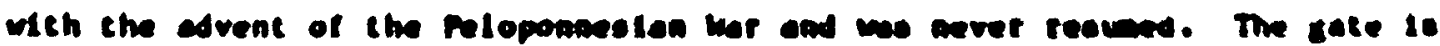

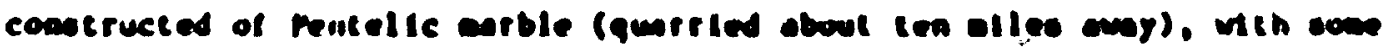

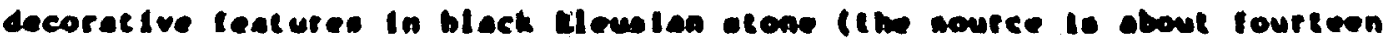

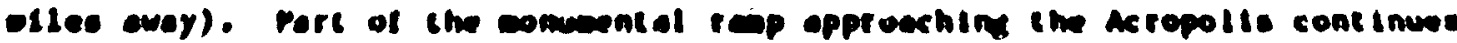

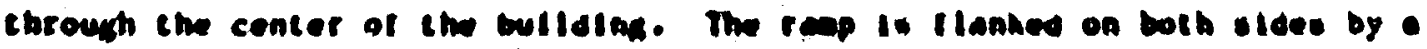

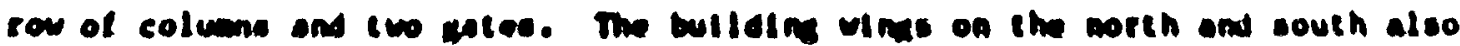

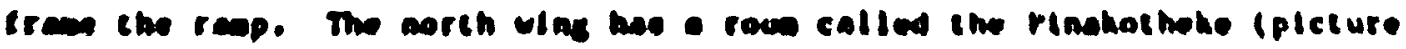

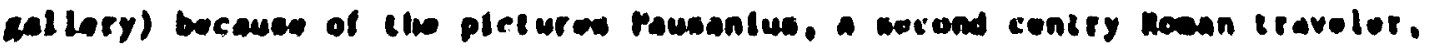

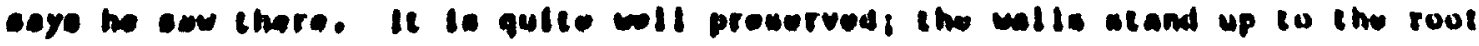
level ond ectll war archituetural feotures. $(31.32)$

The Tepole of achoma wite (Athona, Bringer of vietury) in reachod from the anch ond of the propylata. It is ade of nuliefle marble and uad butle In 427-426 H.C. la celobrate the pace vith rutula. The architect wa

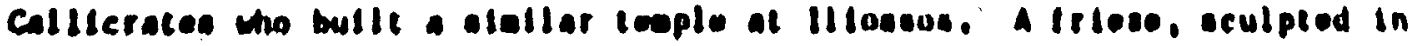
ht gh relief. ran around the extertor of the bulldingt fowr of the fourteen

$80040 \quad 1057$


is

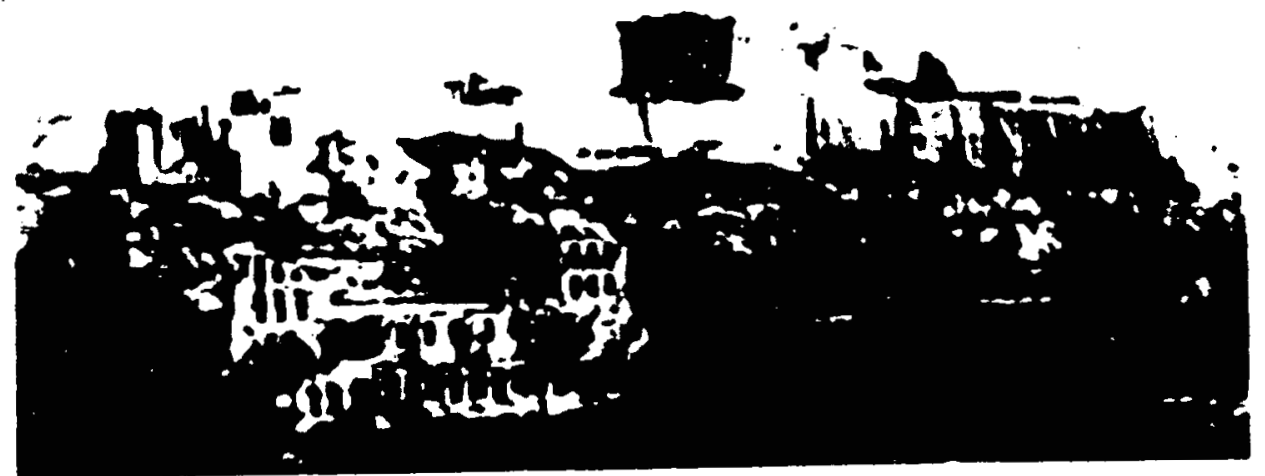

Figute 3.1-3 ithe Acrowolis, Greece

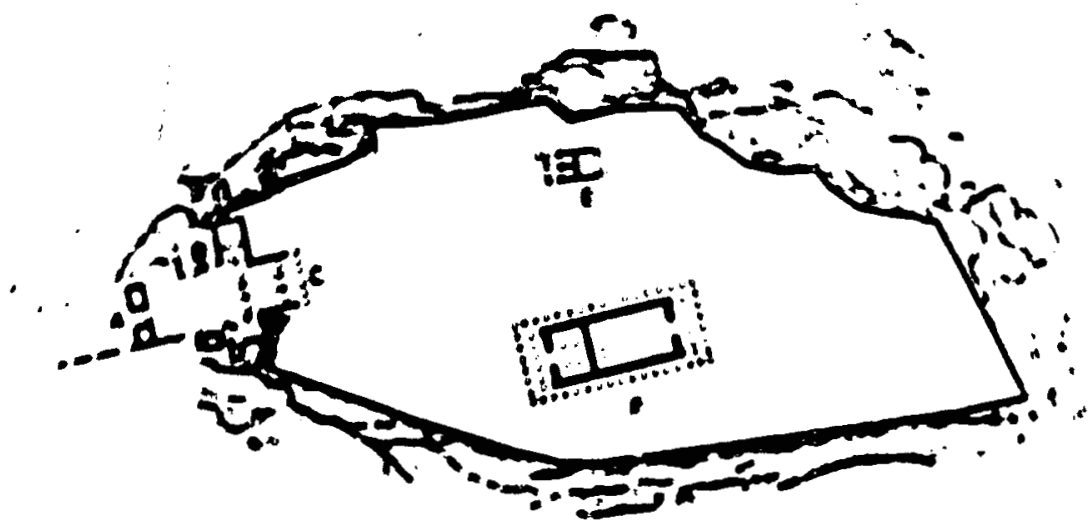

Eay

As soule cote

Di Agripes meanemal

C) Propylais
Di Temple of Altogar Mille

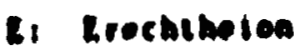

II Parthomon

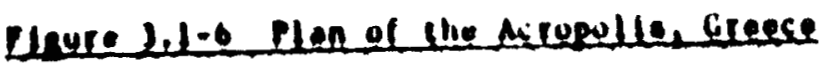

$80010 \quad 1058$ 


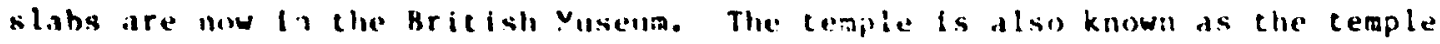
of "hingless victory", a tradtiton recorded by Pausazlus. (52)

The trechtheion is an intriguing cdifice, bullt on more than one level and weant to house several cults, Including those of thena, Poseidon and the founding rulers of $A$ thens. It also housed in aritent and venerated statue of Athena. The building was part of Perlcles pian for the rebullding of the Acropolis. It was begun In 421 B.C.. Interrupted by the Peloponneslan har, and coapleted in 409 B.C. With the exception of dark sleuslan stone used as the background for the frieze, the bullding was constructed of Penteltc arble. The exterior walls and porches are quite well preserved (up to the roof). Differences of opinion exist about the plan of the interlor. which has undergone extenstre renodeling In the course of tee. The southern purch is known as the Potch of the Haldens (or the Porch of the Caryatids). Instead of

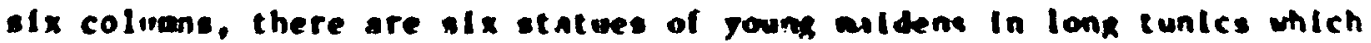
support the roof. One of thene was taken back to Endind (atong with any

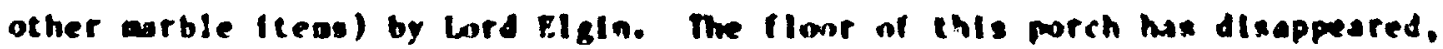
but the celling is mearly intact.

The Parthenon or teaple of Atheme Parthems (vitgln Atheas) ncruples the higheat part of the Acropolls. It wo ceant to we an artistic materplece and to serve as the atale treasury but ant lo replace the crecheheton in renerabllity. Foroling the cardinal fewture of pericles plan, It wa bullt in 467-438 B.C., and the best and cost celebrated sculptors It Athens were eng-

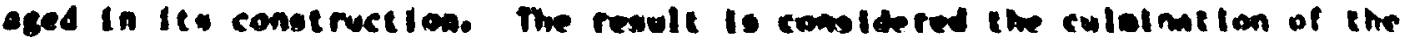
Doric, If mat ithe Clasaleal. atyle of architerture.

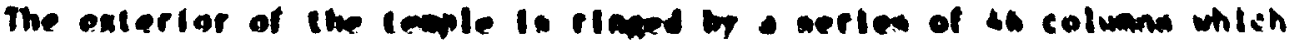

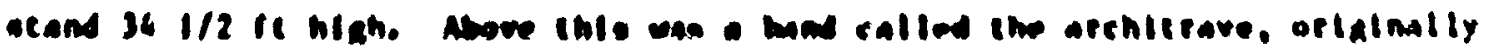

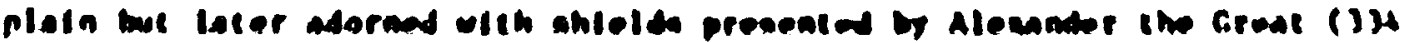

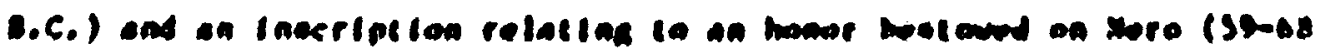

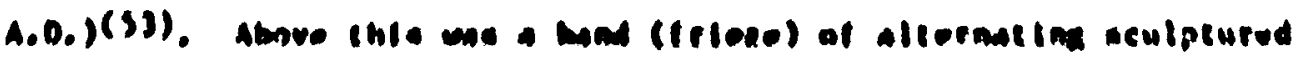

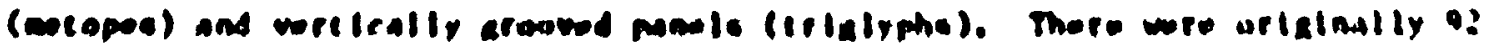

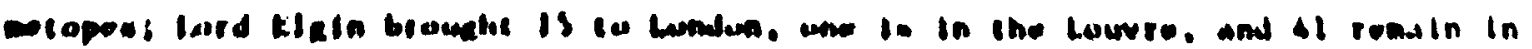

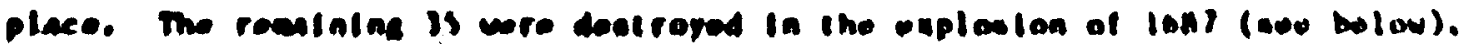

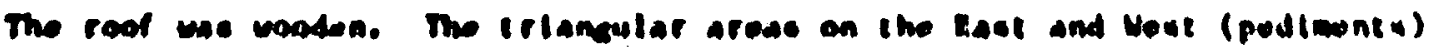

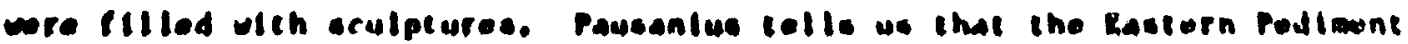
ahowed the birth of achenat it wo largelf dectrayed by the butlding of a

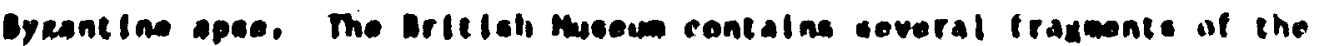

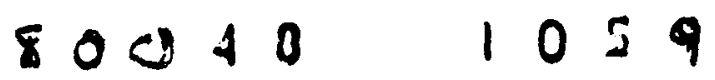


resaining sculptures. The Hestern pedizent showed the contest af Athena and Poseldon; this group was destroyed when the sculpture fell durling repoval in 1687.

Around the outer walls of the bullding ran a continuous frleze of sculpture. Its original length was about $525 \mathrm{ft}$; 176 of whlch exist In Athens wile $247 \mathrm{ft}$ are in the British Museun. The reasinder was destroyed in the explosion of 1687. The entite frlese was dedicated to showing che processton of celebrants in the Great Panathenaean Festival honoring Athena and is known for lta asterful sculptures. ( 54 )

It should be noted that none of chese bulldings have any wortar. The stones were closely ficted by careful dressing, and where extra strength was needed, the ancient Greek used soall bolta and clapo of Iton. These mere rendered nearly rustproof by coatiog the with lead. we whall ace. elellar precautions were not taken at the curn of this centry when restoration work was done on the Acropolls. and the nethods used Mve ectually eccelerated its detertoration.(51,5s)

Who/when - Pericles wes the price nover in the dectelon to rebulld the Acropolis on a comuest al seale after pece we nde with rersie. The Parthenon was wilt irne (447-430 B.C.). then the Prepslate (437-432 B.C.).

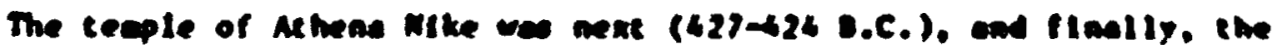

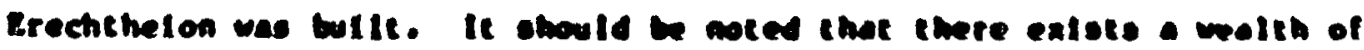

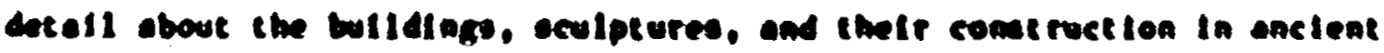

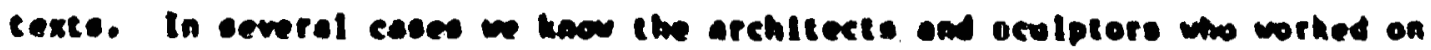

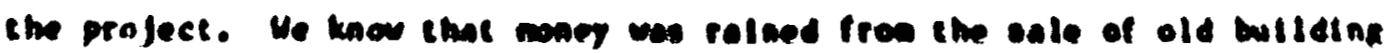

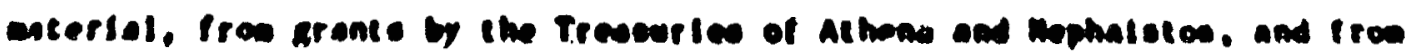

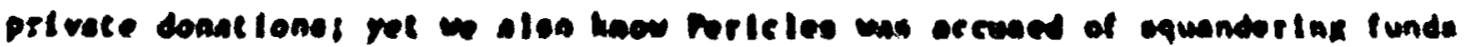

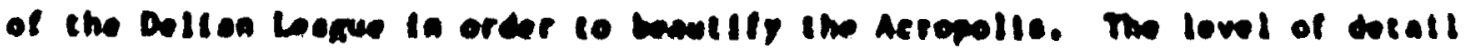

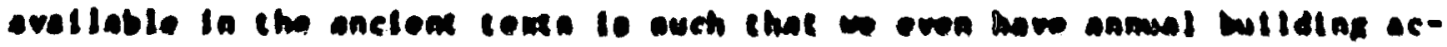

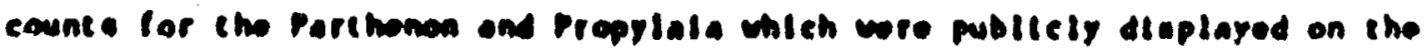
Aerapolle. (S6)

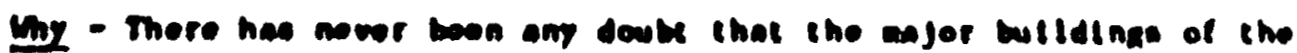

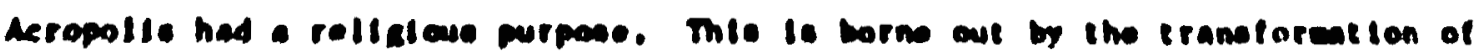

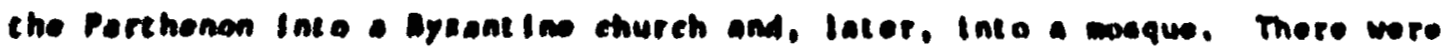
cocular parta, auch as the propriala. Wue the purpose of ench of the bulldinge 14 known.

scate of Precervetion - The last forty to fltiy yoare have vreaked mich

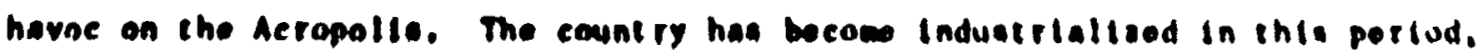

$$
8774 \theta \quad 1060
$$


and the concomitant atwospheric pollution and acid raln are dissolving away the marble sculptures and bulldings. The problen is so pronounced that the clty held the second International syaposiua on the detertoration of bullding stones in 1976. (S7) The Parthenon frieze and the caryatids are under teaporary shelters. There are plans to replace the caryatids with casts and rane the originals to a protected environment. It is ironic that the caryatid rewoved by Lord Elgin Is the one to be the model for the casts. Since te has been indoors for over 150 years, it is In far betcer condition chan the others. $(54,55,57)$

The second problen is that steel bolts and girders were used in the extensive restoration done by Micolas balanos between 1896 and 1933 . Iron was originally used in the construction, but lt wa lead costed co Inhinit rust. No such precaution was taken with the steel replscenents. Aalde froe weaker 1ng. steel expands as it corrodes. Mis extra etreas has led to cracking of the earbie in which the steel is Inbeded; In some places this has led to an inediate danger of collapae. (5s)

The final factor contributing to the destruction of this comment is hwan. The Parthenon wa Intect. though codffled for the erchttecturst meeds of different religtone, unt Il septeaber 26, 1687. At that lice, the Turhs were using the bullding as a pouter ageation and it recelved a drect his by a Venetien corter. The resultant explodien bles the teople into two partn, de-

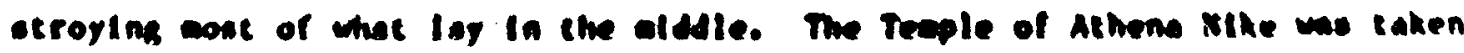

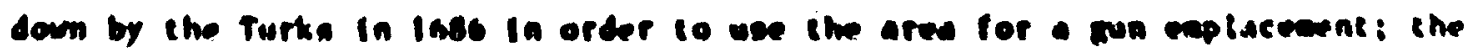

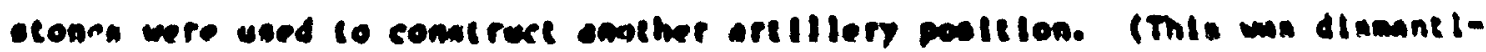

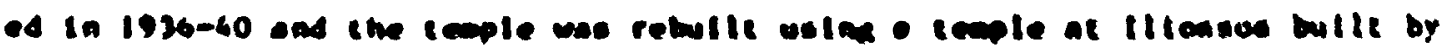

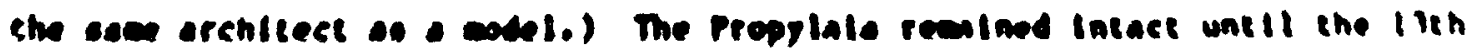

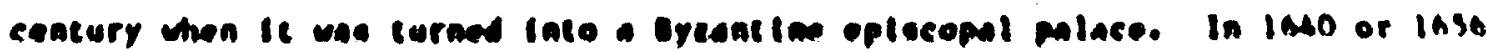

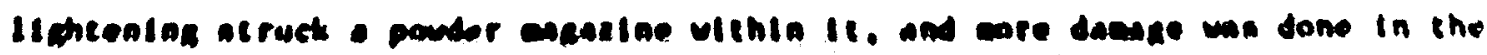

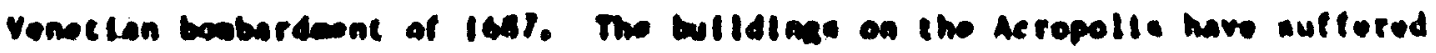

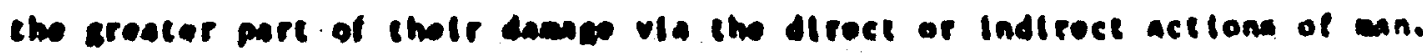
oeher mertere of the sace conre - The Aeropolls of Al hone has alwaye had

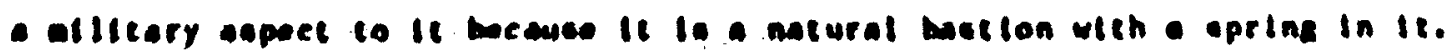

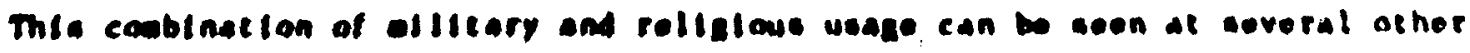

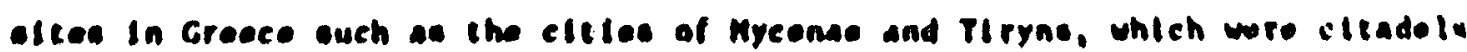

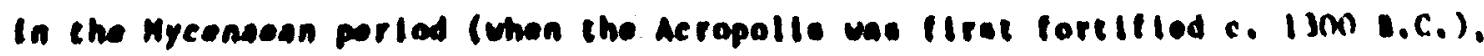
chlle Arsan and cortath had lopeflled elevated areas of the city conteaporarv

$80010 \quad 10 \leqslant 1$


w th that of classical Athens. The temples and secular architecture of the Acropolis find parallels in numerous other Greek cities. The body ni literscure about the Is so extensive that te forms a subspecialty in rlasilcal archaenloxy, and so my other markers exist that they cannot be discussed Individually in chis report.

History - The Acropolis is an example of an area with its monuments for which we can follow the history in some detail for over two alllenta. This thread of information has continued through changes of religion, government. and occupying forces. Its spring and defensive position have attracted human habitation to the area since Neolithic ties (c. 5000 8. C.). In the Mycenaean period (c. 1400-1200 B.C.), a massive fortification wall was bull, part of mich can st 111 be seen today near the Propylala. This wall and an altar see v to have survived until Il the Persian sack of 480 bo. Though lIttle Is known about the Acropolis between 1200-700 B.C.. the contimity of the cults augsects cont inced occupation.

The destruction of the Acropolis and lis rebultaing under Pericles is described above. It we completed to te sch an artistic masterpiece that lIttle was done to it in the following center les. Alexander the Great added

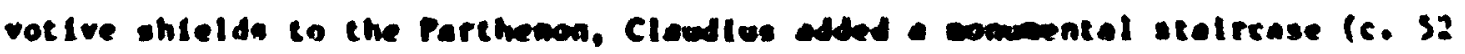
A.D.). and a bronze Inscription howorlag hero wa added in the Parthenon in 6 A.0. . but these were el nor changes.

with the bulling of the chute pate in the tented century A.D. . The

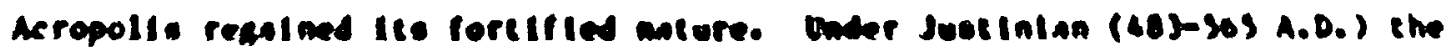

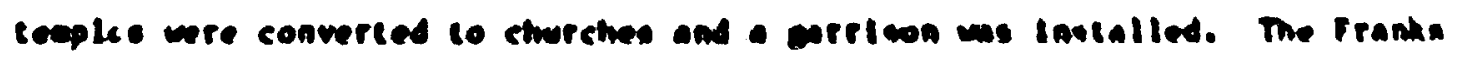

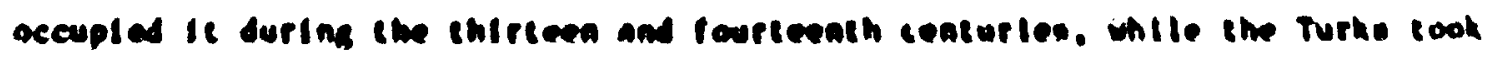

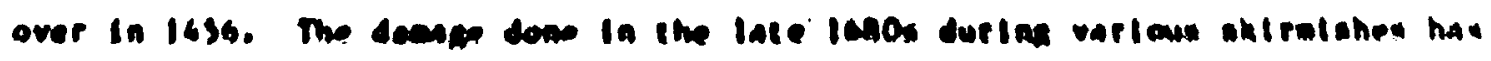

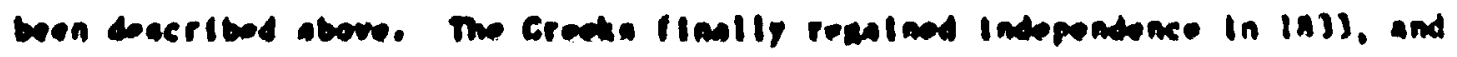

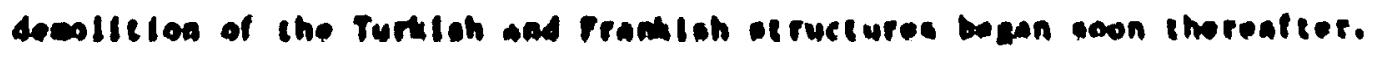

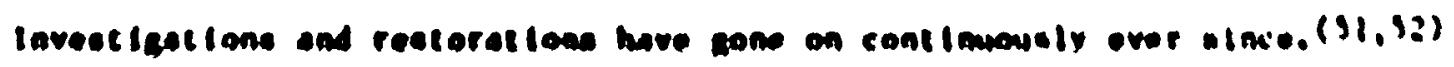

Elevate - The Acropille can provide woeful Information on several

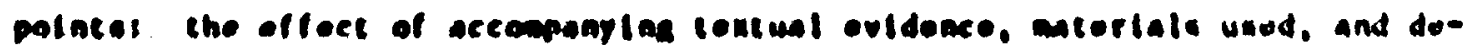

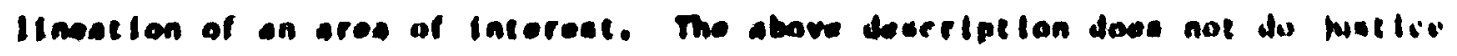

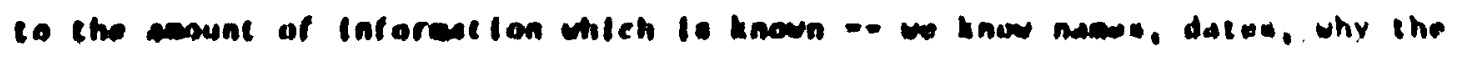

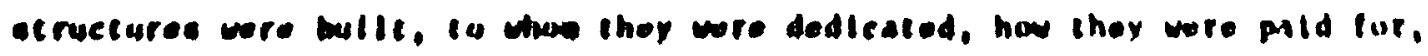
and even ace of the politics involved. We even know. In rather detailed lore, about things mich no longer exiles. For owaple, wow that the

$80040 \quad 1062$ 
Agrippa momaent bore three different staties in lis lifet ine, although che monument itsolf ally reourds two, and none survive today. A more modern -xample at the laforation still extane can be seen in the drablaxs of the sculpluren on the Parthenon produced by Jacques Carrey in 1674. These have proved inviliahle In telling us what was lost in the exploston of lobt and the positlons of the fragnents whlch survived. $(52,56)$ The effect of written records on the survival of this inforation cannot be overly stressed.

Another polnt to note Is that what has survived is stone and not wetal. The bronze shields and the Inscription on the Parthenon vere corn diwn li antiquity. The inacription was declphered by a study of the munting holes. (53) The hase of the Agrippa conument reatins in place utih ita Inscrlptions; the bronze sculpture kroups have disappeared. Again and thain, the holes for count ing etal objects are seen. while the objects are not. 1 glance through a reference text for Greek Inscriptions shows that all but a sall muber of texts nurvive in nowmetal edia. (56) the few which we have Indicate that weal could survive for that perlod of tice. but thit moxt actal weens in have heen recycled.

The present condition of the Acropolls, due to the effects of acid rain. Indicates that not all ateme is an acceptable cediu for repotion arters.

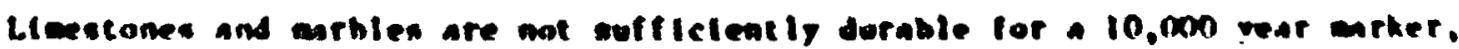
alven the prement levels of ateospherle pollutanta.

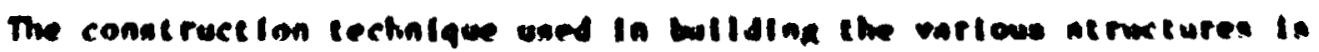

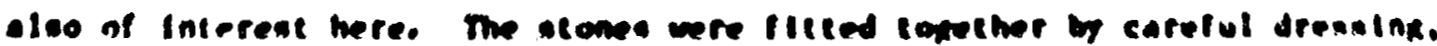
not by the une of corter. This obvlated the and lor certatn type of antro

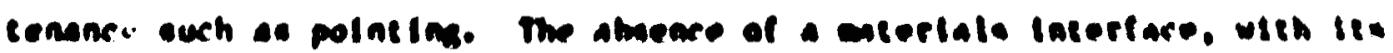

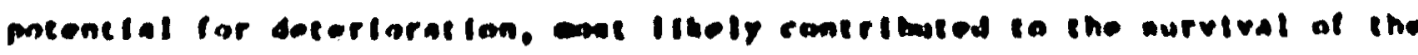

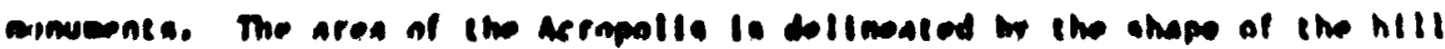

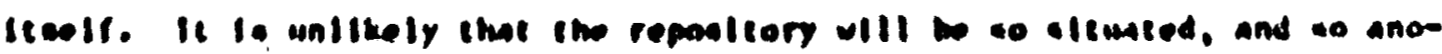

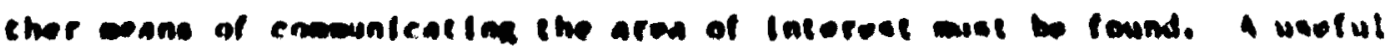

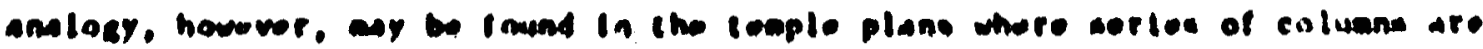

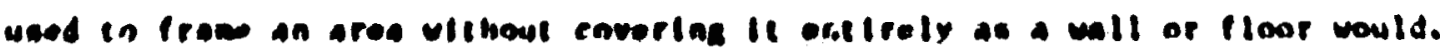

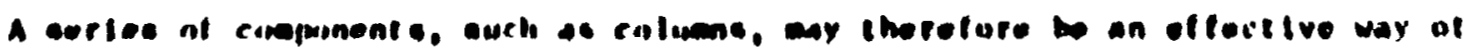

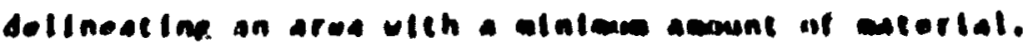


3.1.h Creat Wal1. China

The Great wall of China has been called one of the woinders ot the world. It originally stretched trom Shanhalkuan on the Yellou bea to Kiayukuan in the West, a distance of sone 1850 atles (Hgure 3.1-7). Later daitions, loops, and Inner walls have nearly doubled its length.

The first wall was built by Ch'in Shin thang Tl wo unitied China and wo. In chinese histories, is better known tor his "burning of the bouks" than tor the wall. The Wall wa begun in 221 B.C.. Inediately after the tinal conquest of unification, and was completed in 210 B.C. The rapid tine of coepletion was possible because the Wall Incorporated sone 1300 diles of wils bullt in earlier tiees. The actual bollding of the wall was entrusted to general very t'ien.

The wall wa begua by setting up a eerles of wetch towere alond the trontier. These were gewerally 40 ft high and 40 le squete at the bas. teperins to 30 it equare at the oumit, and were located the leagth of two bow ohots apert. Inis ceant thet the eatire leapth of the uall could be effectively defended. Alet the watch towere were cowetrocted, they wete jolved by wall

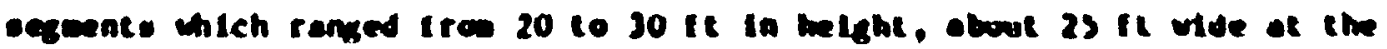
bese, and is to 16 it wide at the top. Plgute 3.1 to obve a equent of the He1 1. $(38-6)$

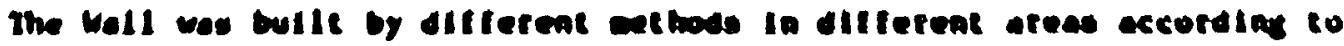

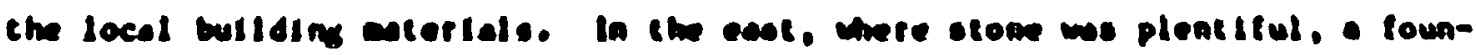

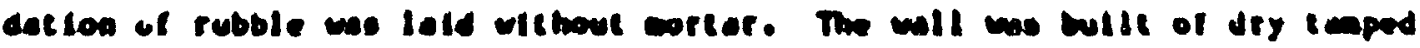

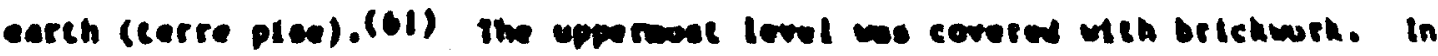

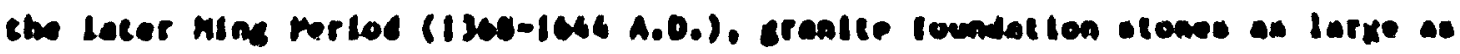

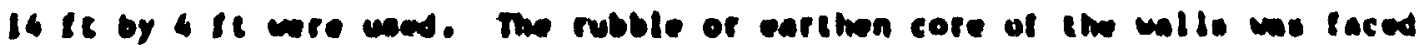

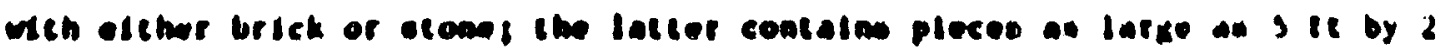

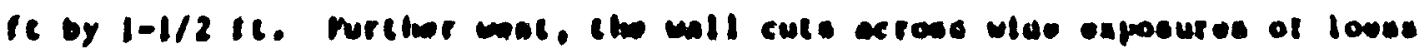

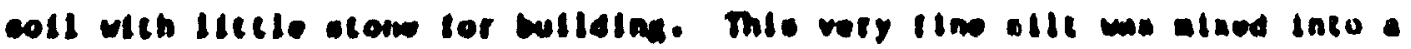

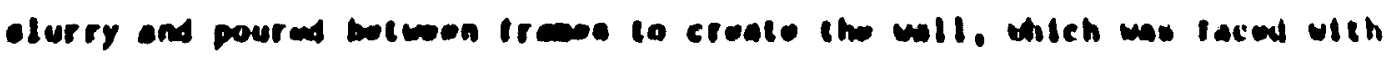

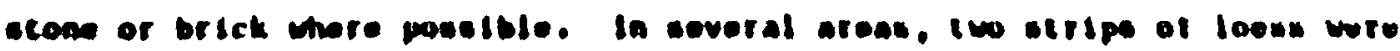

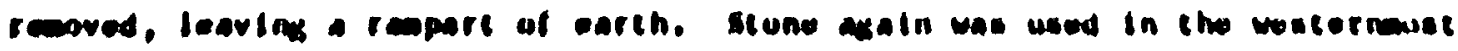

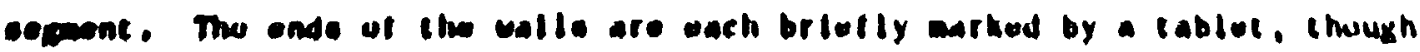

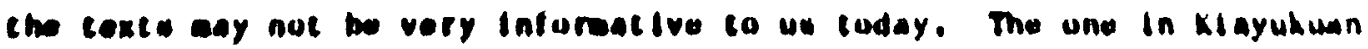

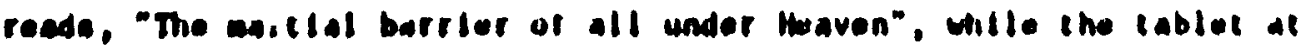

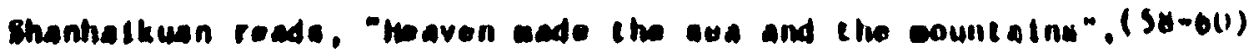
80010
10 i $i$ 


$$
\approx
$$


Wholbihen - The Idea of the dall was concelves sy Ch'in Shth Hudng Tl, and was carrled out by his keneral heng T'len. The Eonstruction wis stareed in 221 B.C. and ended in 2111 B.C.

Why - The oxst commonly stated reason for the wall, and one which is borne out hy the Inscription at Klayukuan, was that lt was to keep the barbarlans out. But the lavish expenditure of manpower and capltal on an endeavor which did not work has proxpted other sugrestions. The construction of the wall began very shortly after faperor $c^{\circ}$ in finished compering China. It has been suggested that the wall was bullt to provide gaitful eaployment for all the vast nubber of soldlers who were now uneaployed. Another suggestion was that the wall not only served allitary purpose but also arked the -outuard linte of desirable expansion" drauing an arbitrary line be:ween the nowadic and agricultural populations. (62) Finally, the wall served to ear phastze that there was now me China under one rulet with a single northern border, and so eaphasized the bonds between the forwerly wartian. etates. $(59.60)$

state of Precervation - The section of the uall meer nehlas wes rebulti during the Wing Pertod (1360-16h4 A.0.) and is in excelleat condition. Mis

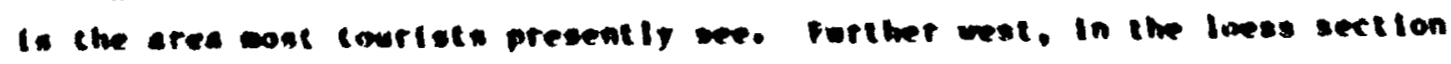
of the country. the wall wo ante sobject to cetertoration atwe the ennmer of

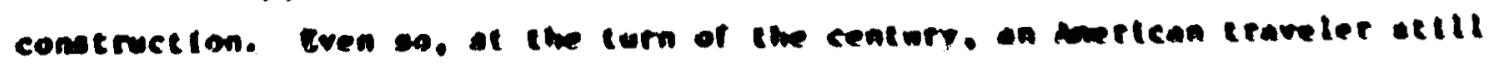

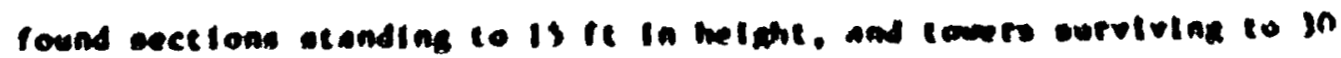
fe. (se)

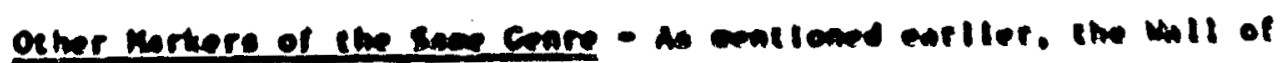

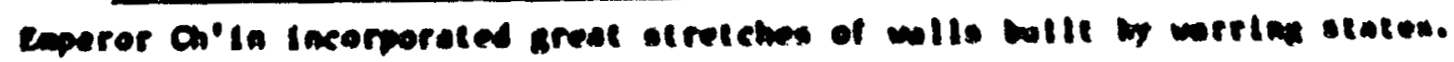

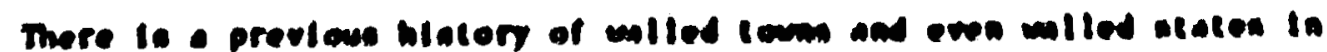

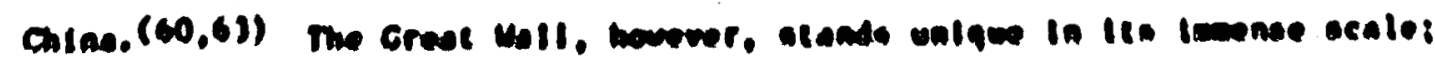

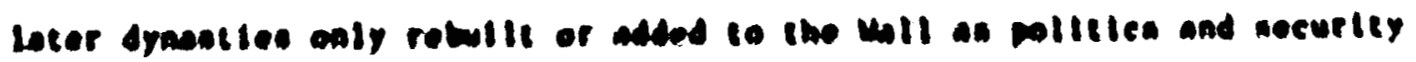
repel rad.

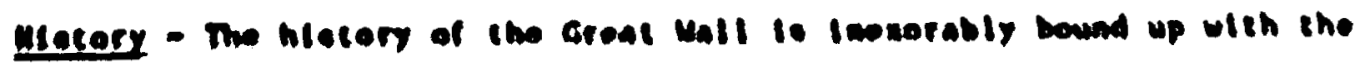

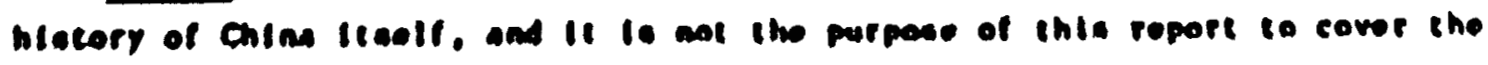

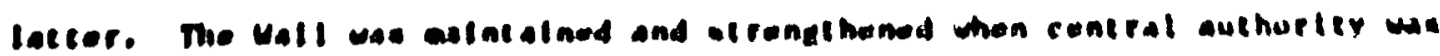

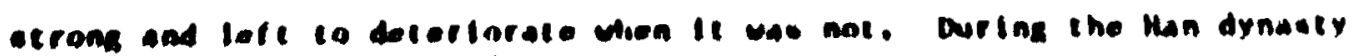

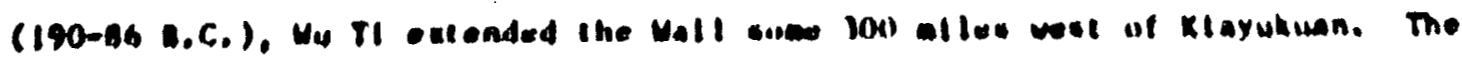

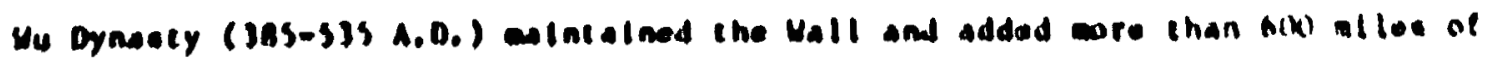

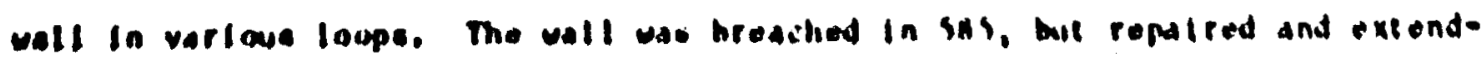

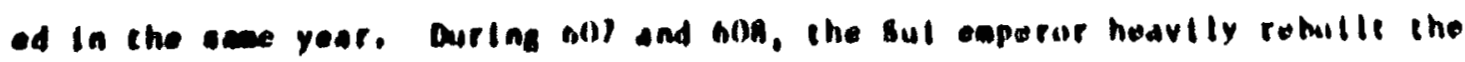
80040
$10 \div 6$ 
wall from the Yollow Sea to tle Yellow River. The ensulng T'ang dyads:y (6/8-906 A.D.), however, refused to malntaln and repale the Will. ilth the fall of the T'ang dynasty the northerners crussed over, only to fall latur under the Mongol Invasion (thirteenth century). The wall was of litele iaportance to the Mongols, although Genghts Khan had been defeated for yedrs in his atteapts to get over the wall. The Hongols were chrow out by a native Chinese dynasty. Che Ming (1568-1646 A.D.) who prubably carried nut sore construction on the Wall than any other ruling house since Eoperor Ch'in. The any plaques and inscriptions in the wall comoenorating the rebullding if sections of the wall date to the Ming perlod. These can stll be seen and read today. The Manchus (1646-1911 A.D.) were wortherners who replaced the MIngs, but had been Invited across the wall by a Ying eaperor fighting for hls throne.

This takes the history of the wall dow to thla century. The wall has been breached and repalred but never forgotten. Dor does ints hIstory do fustice to the acount of ilterature intch has grom up arouad the unll. ranging from poew about its beaty to tales of the hortors embred by the conseripted laborers wo bilt It. Passing the gate at klavaluan was canteownt to leaving all that we ciolifted in the world and is often nn portrayed In Chimese itterature. In short. It was an Integral part of chinese allitary and cultural hiatory. embering severat centurles and chanken in poverneent. $(39,60,63)$

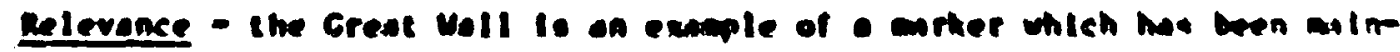

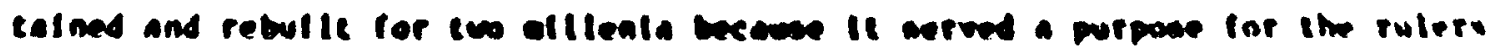

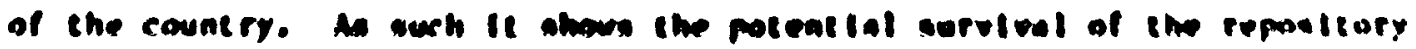

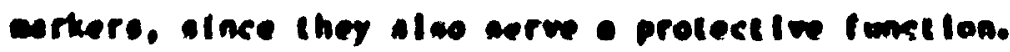

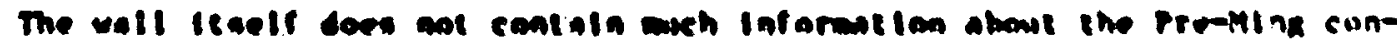

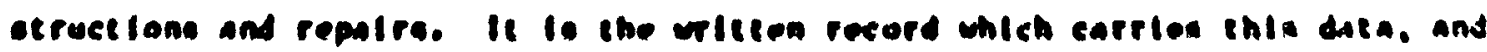

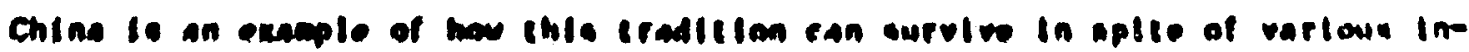

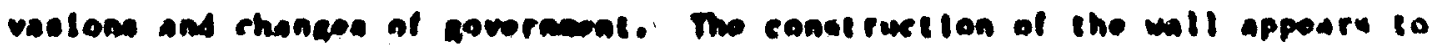

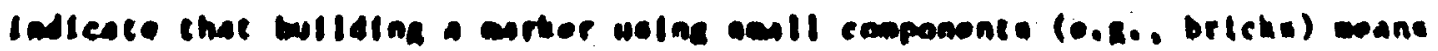

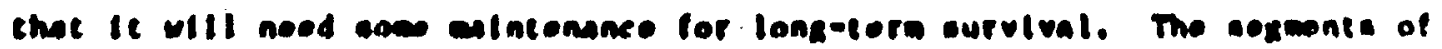
caped earth or lages, hovever. are eflll vialble even after the factas of brickwark has fallen way. 


\subsection{Discissitis}

This section sumatizes how the Information on the various monuments presented in Section 3.1 relates to the issues on repository marking discussed in Chapter 2. The discussion will follow the order presented in Chapter 2 -nessage existence, detectabllity, and comprehensibllity.

\subsubsection{Message Existence}

A polnt wich is wentioned repeatedig In Section 3.1 Is the Ieportance of uritten records to our understanding of the anclent ennuents. The purposes of the Pyrantds, the Acropolis, and the Great wall are knom beceuse they were bullt by literate cultures tho asde contemporary records. Inis Inforation has elther survived in the present time, or has been recovered and opread in a vider audtence through scholirly work. The level of detall is such that we not only know why they were bulle, but by whow and, somet lass, even hor they

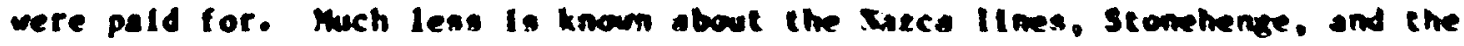
serpent Mound. Thefr bullders are known only by keneral cultural anase, not

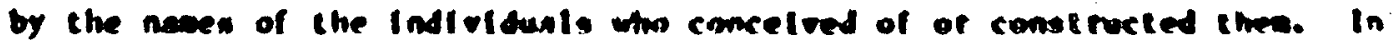
other words. It eppesta that:

- Level III and IV Iaformetion no oaly be cartled by the urtesen

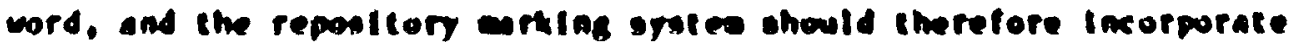
this.

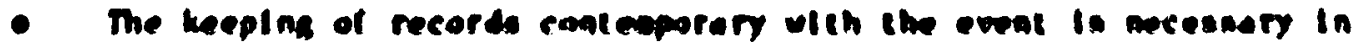

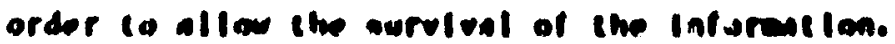

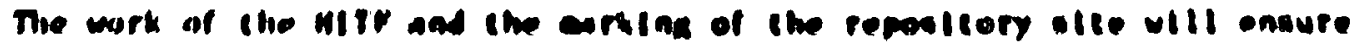

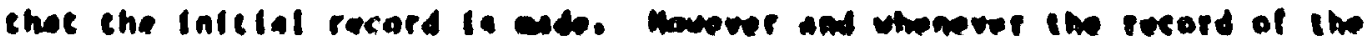

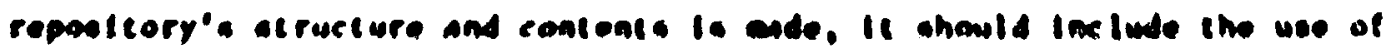
uritien recerds.

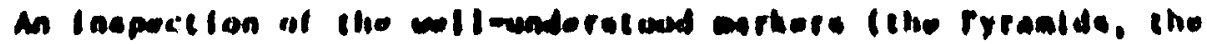

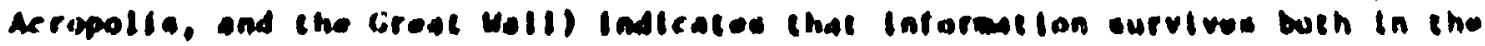

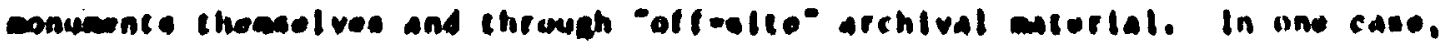

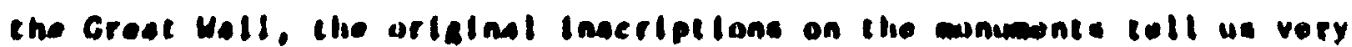

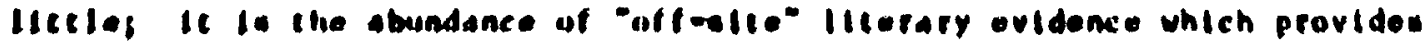

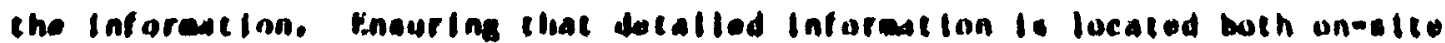
and elachier ufll laprave tis Ithellimed of survival.

\section{$80010 \quad 10: 8$}


The nonuments discussed in section 3.1 may also be used to cument on Dessage survivability. Several of the ponuments, the Acropolis and the bazrd lines in particulat, have sutfered their worst degradatlons at the hands of ean, not ot nature. The monwents which survived in better condition were those which ainiolzed the need tor active oaintenance. The Acrupolis has no wortar used in the construction of its vartous bulldings, wile the nazca LInes, Serpent Mound, and Stonehenge needed no wortar due to the is weans is construction. In contrast. the creat wall used brick and wurtar construction over wuch of its length and it needed active aintenance over the centuries to survive. (The Great Wall, however, is an exaple that such extended alintenance Is posatble tor at least two thuusand rears.) Another point is that all the wonuments are banufactured trom whet elght be called "abtural beterlals". L.e., stone or earth. These aterials need only to be ohaped to be used in

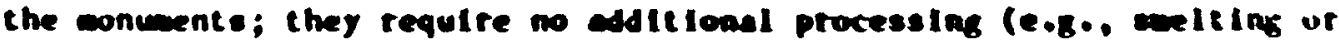
casting). The cholce of thewe uaterlals ar teflect the techmological IIbit of the cultures chich used twew. hownet. Ihis does not negete the lact that chese ancient commente huve servived Ia a varlety of clicatee tor up to 3,000 years. It should also be noted that wetels ate not oultable tor curkete be-

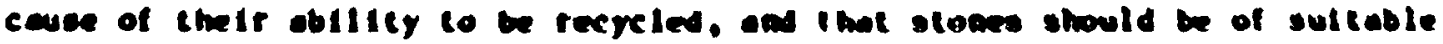

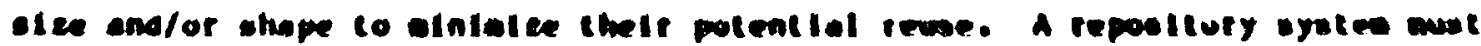

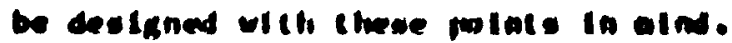

\section{2 .2 meere inectobilisy}

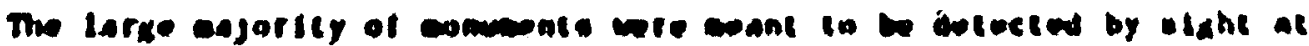

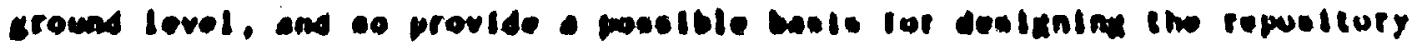

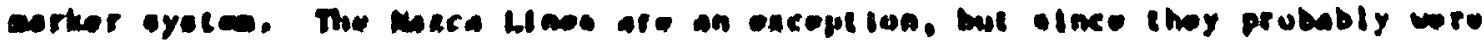

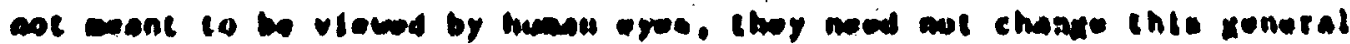
oberraction.

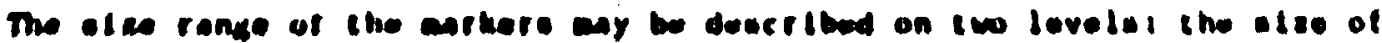

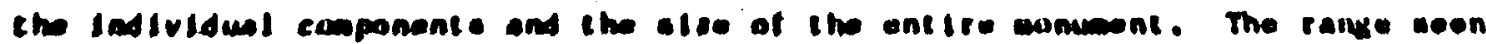

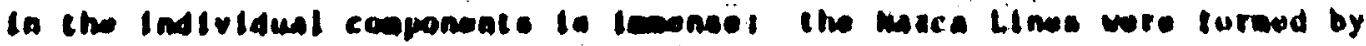

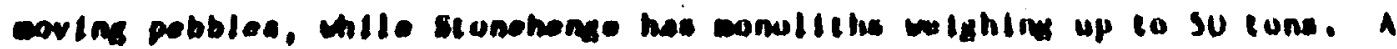

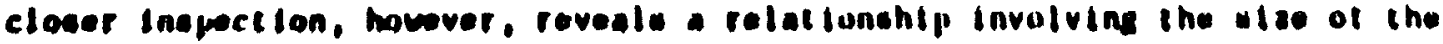

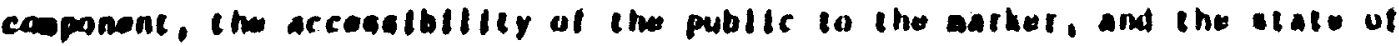

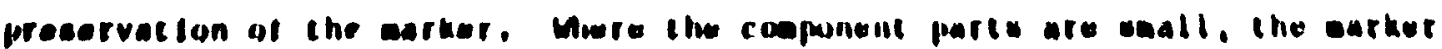


seems to have survived because it was located in an lsulated reglon. This is the case with the Nazca lines and with some of the swaller stone rings In the British Isles.

Three of the monuments discussed in the previous section are loctled near large population centers and have survived. The large sizes of the stones at Stonehenge have ande the rather difflcult to topple and vandalize. On the other hand, the Pyramids were ade of smaller stones and have been used as quarties. They have survived only because of the labense nubber of stones used in their construction. The Great Wall has been alintalned because it served a protective function and is of cultural leportance.

A far more subtle telationshlp exists between the slee of the Individual components and the size of the entire monument. Stomehenge, the Acropolls, the Pyramids, and the Serpent Mound can all be taken In at single glance. The patterna and foras of the conuments are lanedlately perceptible. The perception of form and conteat holds true for the Great wall as well, even though the monument cannot be viewed in lta eatirety except, perhaps, by satelitte. An Inablitiy to percetve a comment leads to a lack of under standing sbout it. The waces limes are an exuple of this, and the phemowenon ay explain my the stone circle of Avetury, wich is far larker than stonehenge, in less widely haow. The cooponent parts at Awewry are sall compered to the acale on with thet ore set. and it is apporentis casy to seand in one part and not realles that the retalining cection of the manument

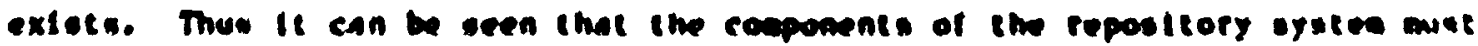

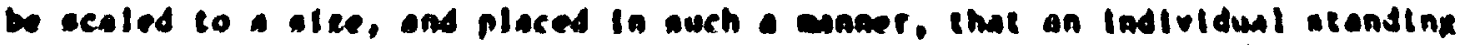

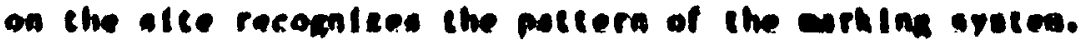

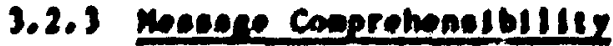

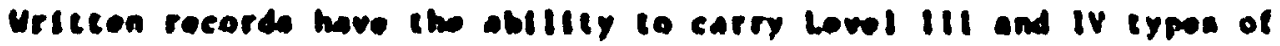
Iaforactoa, ovon though languages and cultures ey change dracaticaliy. In

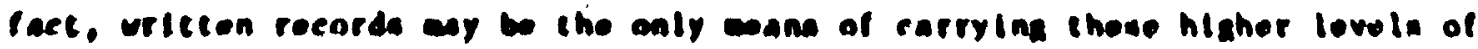
lafarmetiong the hitatory of stanghonge polnte out the posetble curtuption

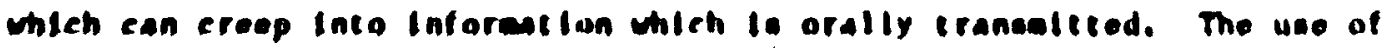

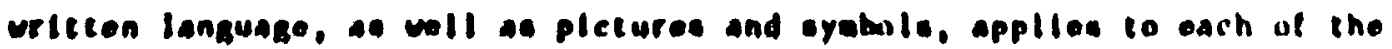

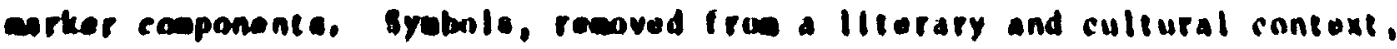

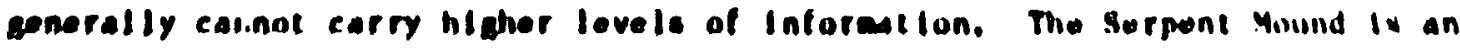

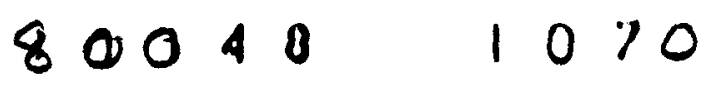


example of thls phenomenon. The pattern of an entire marking ipstern. like those of the anclent monuments, must be recognteable in order fur the monument (s) be properly comprehended. This ay be done by using component parts with sultable slzes and locations. 
$\therefore 1$

6 PREI.IMINARY RF:POSITORY MARKFK SYSTFM DFSIGN

This chapter presents a preliminary marker system design which incrborates many of the post live features found in the anilent monuments. Since the monuments discussed In Chapter 3 are only a small selection of the material surviving in antiquity, this chapter will begin by presenting a deduction of useful options which can be draw from this larger body of information (Section 4.1). The marker system design is presented in Section 4.2, with various options which address the different issues that are presented in Chapter 2. It may not be necessary to Incorporate all of these features in the final design, but that decision rests with the HITf. Section 4.3 concerns the messages that the market will convey.

4.1 DEDUCTION OF USE PUL DESIGN OPTIONS

The previous chapter described several monuments which have survived for extended periods of the. With this information as background, we now turn in the problem of designing a esther ureter for a nuclear mate repository. Usefut option e (materials, construction, and the wean by which the information 1. conveyed) ar be identified by a deductive process which is shown scheat icoly in Figure 4.1-1.

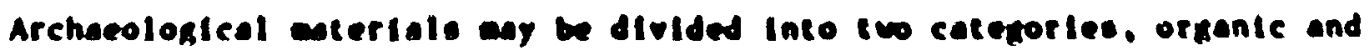
inorganic. The former category to not vultable because oriente materials do

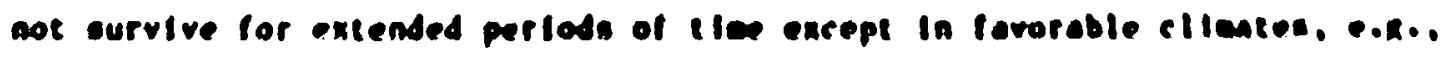
deserts or aneroble boke.(42,64,65) information about ouch materials way be stored if they will be located in a protected environment le xt.. paper in a

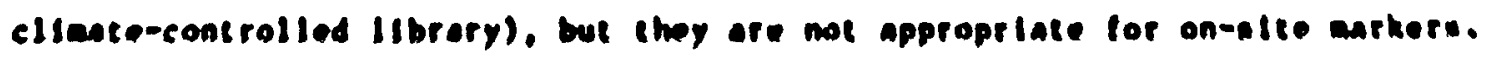

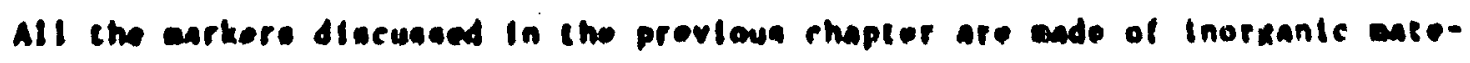
rials.

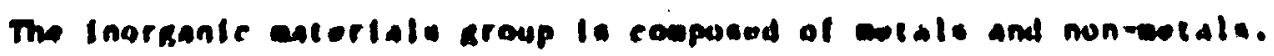
Metals are not acceptable from an archaentonteal point of view because indy chaw a ec rank tendency to be recycled by humans. mi s holds not only for the

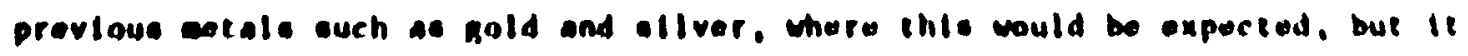

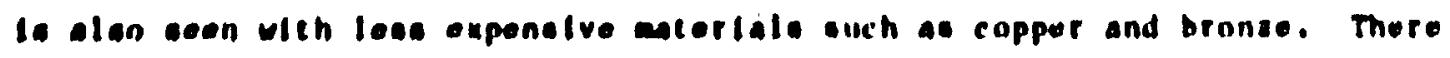

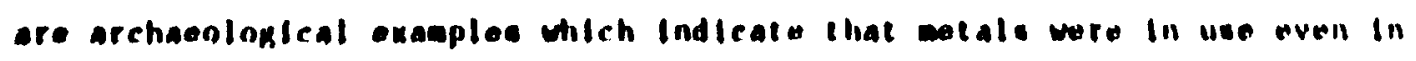

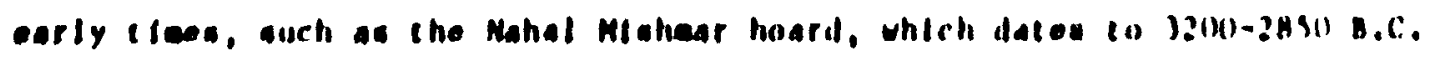

80010

$v_{i}$ 


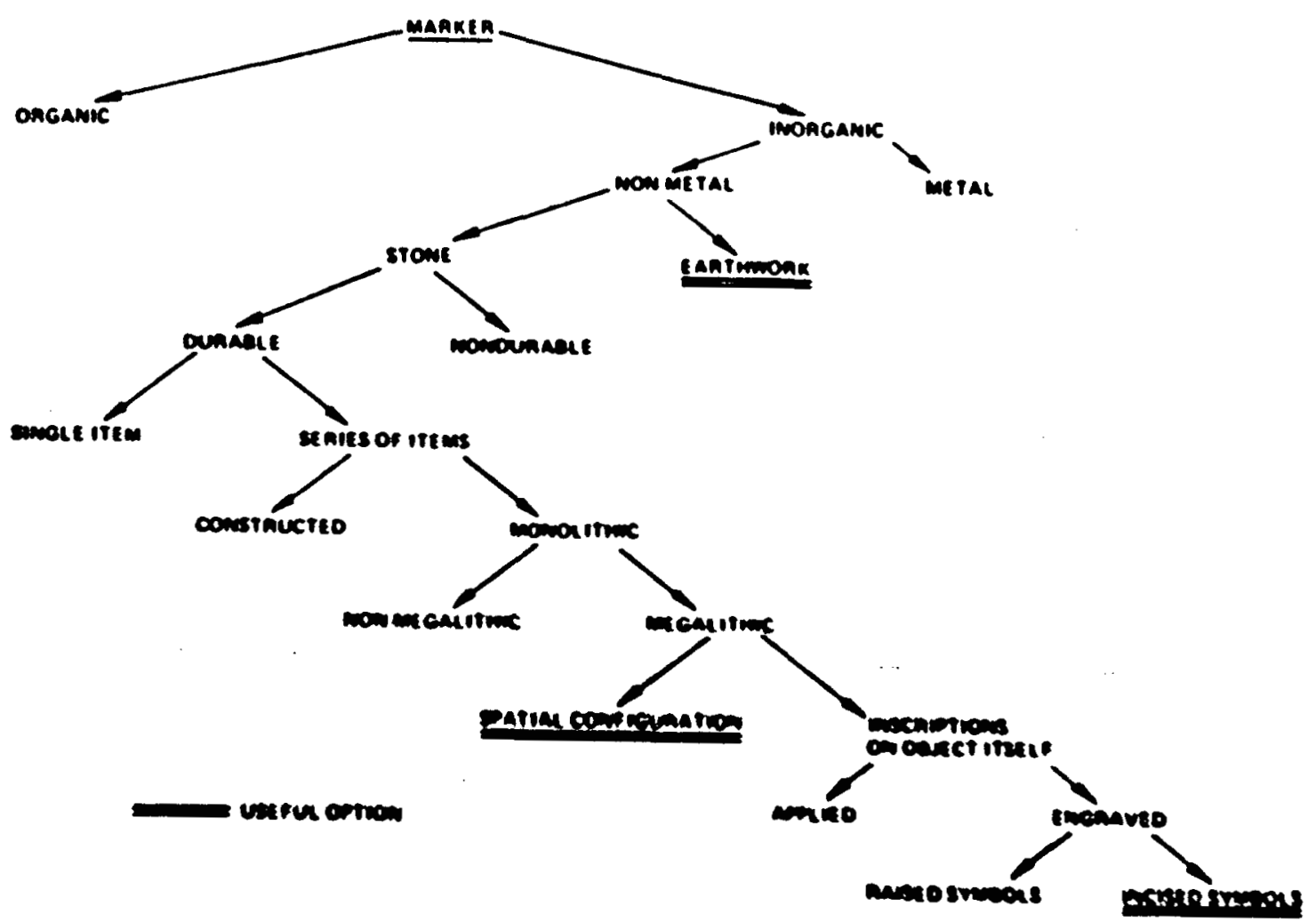

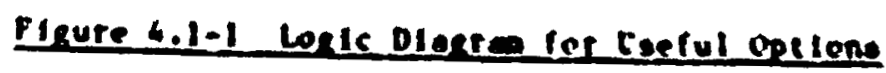

and contalned over 400 copper objects, but these appear to be the except tone wich eacaped belng alted dow and reused. $(60)$ (since we do lind these

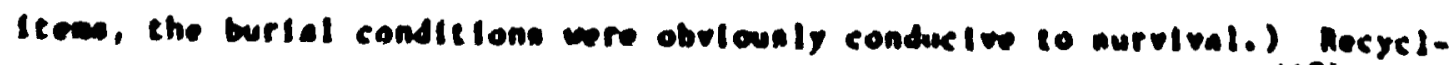

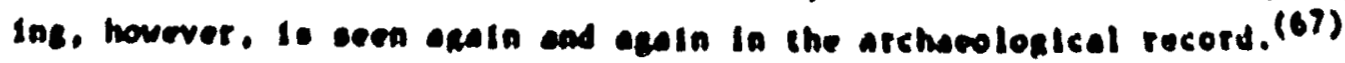

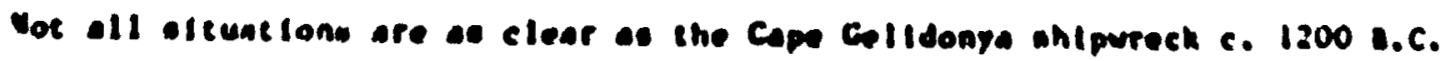

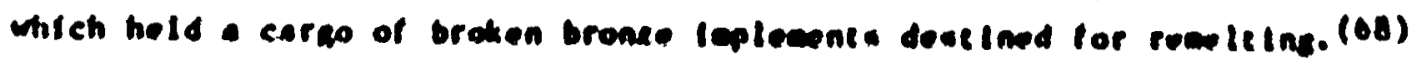

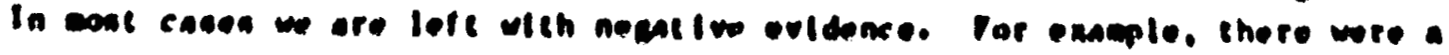

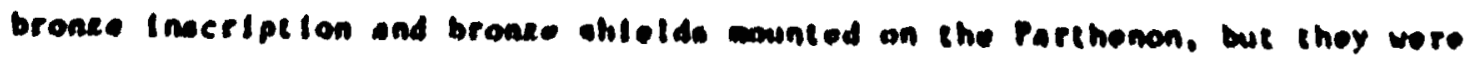

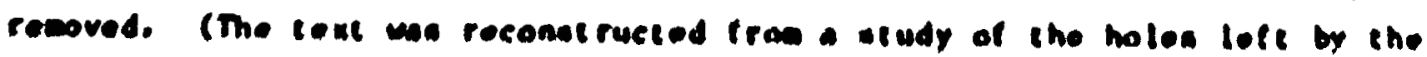
covating plan. (SJ) Wo only know the ahlelda onluted trun contenporary cueriptione.)

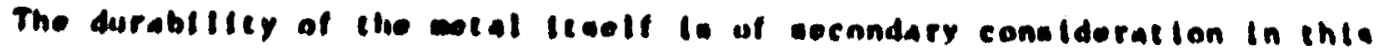

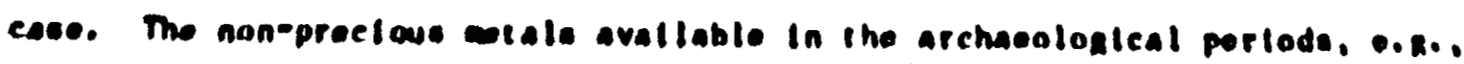
copper, tin, bronee, and lead are eypleally tound in atate that would indt-

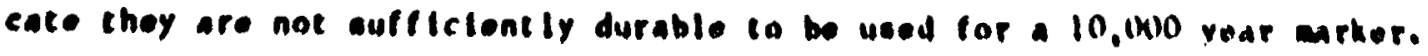
80048
$10: 3$ 
There are, however, mollern met $1 \mathrm{ls}$, e.ge, titinlum, which are fir more durable than these. But the archacologlcal coldence Indicates that the inteinste value of metal mikes it highly probable that it will be recycled. In other words, although molern metals bay he sufficlently durable, markers made of such materlals are not likely to survive. It is this aspect, $1 . e$. , human action, whlch removes metal from further consideration.

A non-metal marker may be constructed out of earth or stone. The bank and ditch enclosing the stone ring of Stonehenge, Serpent Mound, and the Great Wall are exanples of surviving earthworks. ThIs, therefore, is a useful option but one which is restricted to conveying infurasion in fts furo or outIIne, thereby 1 islt ing the coaplexity of inforation le can carry. It would be suttable for delineating the repository area. Annther posslbillty would be to make the earthwork in the form of an Internat Ional hazardous waste syabol.

The arker system way also be constructed out of stone. Within this category, however, there are some unacceptable aterlals. Softer stones, e.R. nteatite, are too easily damaged by erosion, abrasion, or Intentional disf igurewent to make dentrable arkers.

Marblen and limestones were comoniy used in bulldinga and monuments. They have, however undergone severe deterloration within the laxt hundred years or wn due to the increase In Induntelial pollution. The Acropolls in Creece han several bulldingn mich are bult of arble and are nuffering noticeably fron severe deterinration. The anthed changes which have occurred within the lane century ay be seen by comaring a cast of one of the Parthenon rellefw with lian le lonks today. (69) The replacenents for the Porch of

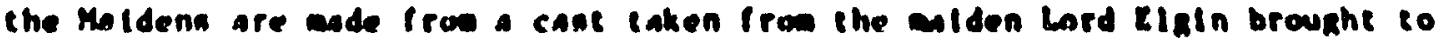

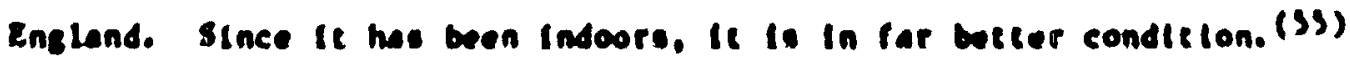

Industrial pollution hes created a conservation problem unteh is rellected in the numprous areteles on this tople llated anmully in Art and

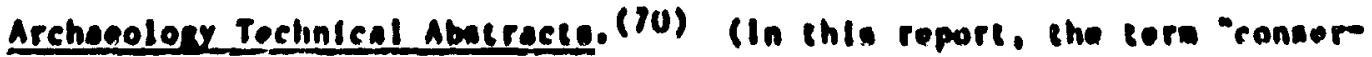
vation" rafera in the ropatr. consolldation, and protection of antiquition and worke of art.) The jortey of these articles are concerned with warblea and

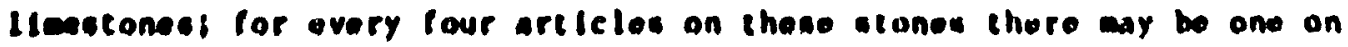

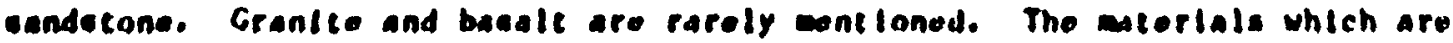

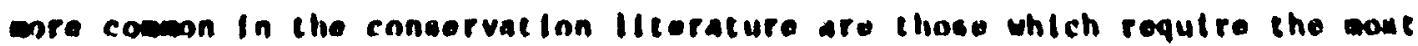
repalr, reconatruction, and treateent to prowervo. The ouro durable mato-

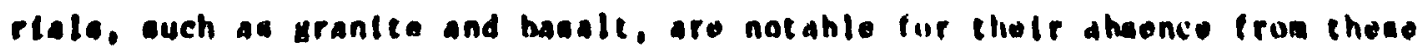
Itere.

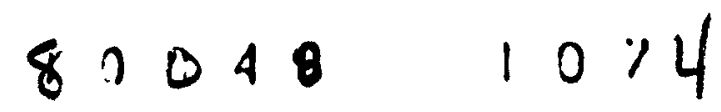


A final pat In the irgu ent agalnst the lase of warbles or limesting lis the fact that :ay are often burned for lime. Many pleces of antiquity have disappeared in kilns. (71)

Recent work by lewin and Charnli indlcate that llastone and arthles show signiftcant direct solublity in environaneli iter. (The lark of rilafall In Egypt helps to explain the better sondttion of the monumes there.) Quartzite and arkasic sandstone appear (b) decorlorate ante fros seresi tncurred by freeze/thaw and wet/dry cycling. (72) sindstancs also tend to suffer from surface friabllity $(69)$, a factor detrimetial to preserving an tiscripton.

Tuff Is a material which has been used for bulidings. (73) Althoigh it 18 strong. the ease with wich it can be carved akes it unsultable for a repository marker. It may be destroyed tme ealli hr vandilisa.

The reailning rock. wich ay he sultaile for the earkers wuld have the following characteristlcs: hard, comact, non-hrittle, and relat ively homigeneous. The harder a stone 1s, the wore difficult it Is in untk, ind therefure the more difficult it in to deface or abrade. The ter "conpact" here la used In the wense of heing fine-gratned and lacking cavitles. If a senme iacks this characterintlc, two difficultion rewult: the Inatility to hare shafply

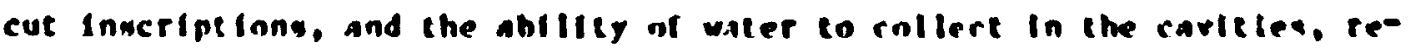

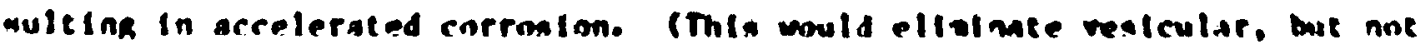

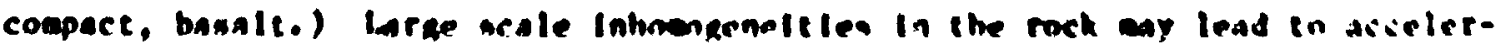
eted corrosion alone eroin boundarlea. One hrmpeneows roch is quarts. but

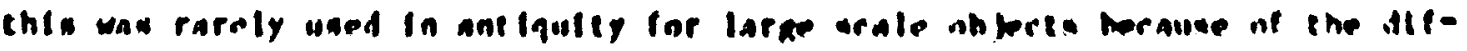

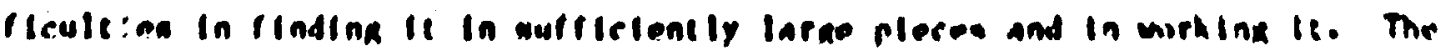

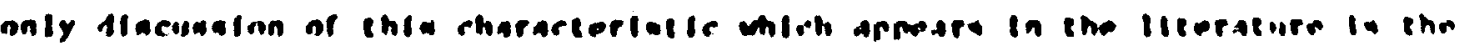

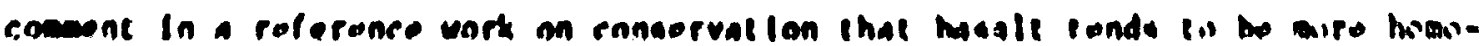

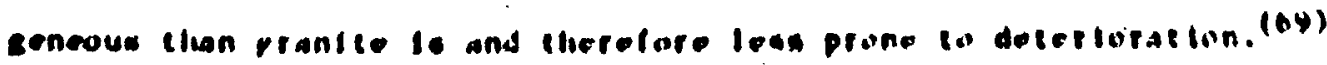

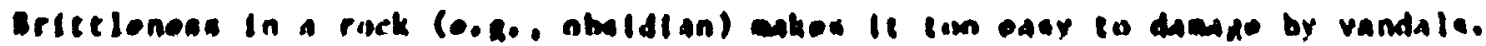

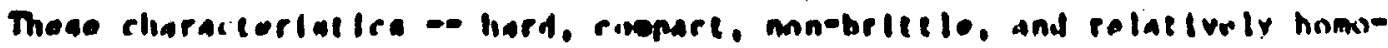

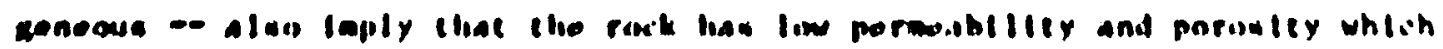

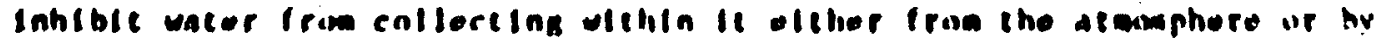
wicking te up tron the antl. It to the uptake of vater uhteh ran lead ton corroston or in the bulldup of sales frob the prikinduater. Tha later crvatalltze out on the aurfare of the ahject exposed to the atmiphere. Thts phenowonon has been notod on buth stene and fired clay oh focto. and may roulite

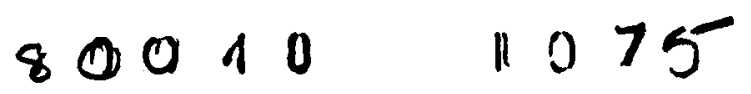


In exfoltation of the surface of the objecte(by, ta) This problem aill he minimized by site selectlon factors which make it unllkelv fur a reposit.ery tw

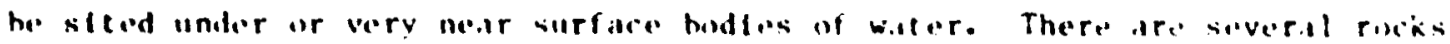

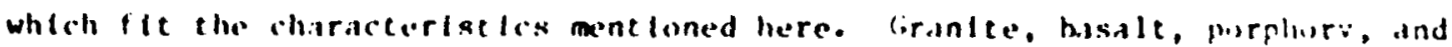
quartz are some examles. Yodern miterlals sclence also allows tile posibi:iity of creating a man-made stone for this puroose, but these have niv ariadelogical precedenta and therefore fall outalde the range of this discussion.

Having suggested a class of acceptable materials, we now turn to the plan of the marker systea. The first question in address is whether there should be a single marker or a serles of markers. A slngle warker, he it a pyramid, temple, or figure, tends tn ark a spot. It Is, then, a polat estate. A serles of markers, such as those at Stonehenge or the coluans around the Parthenon, tends to define an area and an is mre appropriate sor the pritject at hand.

A single marker han the added disadvantage of belng con easly dretroyct, chereby leaving the repontcory without any earting whitsoever. In urder to bulld a ingle an rker which ts sufficlent tn withatand the ravakes of vandil-

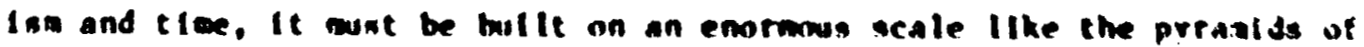
Egypt. A nertes of artern. on the other hand, wowld be leas cnstly to erect and would provide the dealign with ame redundancy. For exangle. the plan of stonehenge can be drawn, even thouph a third of the atomet ate niening.

The next quewtion in wether each enrther Itnelf should be a insle plerp construction (amolitli) or bullt of comomont parts. A ronstrweted ather has

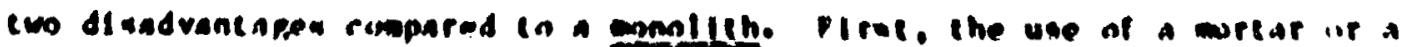
binding agent between the camponong cels up a materlate intertace uhlich lo

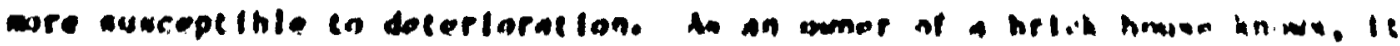

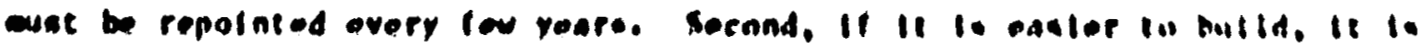

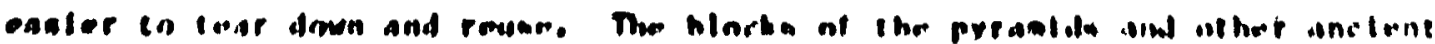

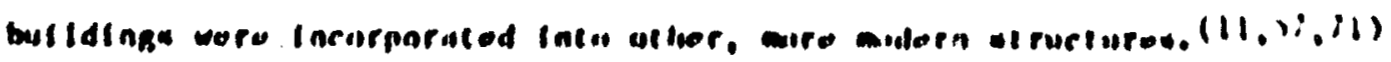

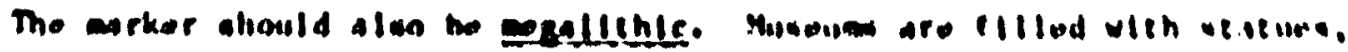

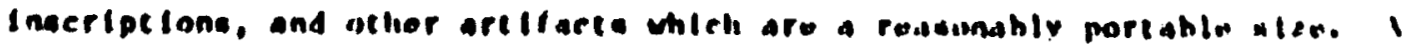

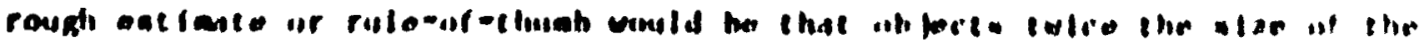

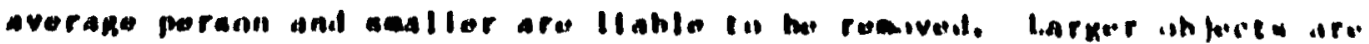

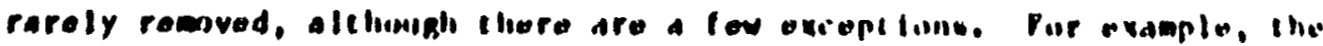

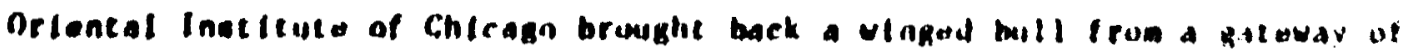

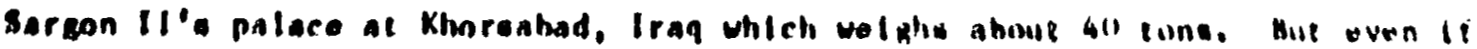
80018

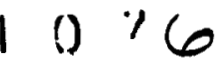


I few of the mirkers are taken, the remilnder would contlaus to consey the desired informition.

The serles of monolletis can convey informition by two meins: spatlal conf Iguration and Inscriptions on the object Itself. As with the earthwisk. the spatial conflguration can convey only a parelcular type of informi:lon delineating the repository area or foraing the hazardous waste syabol.

The planar surfaces of each monolith are quite sultahle for carring a wessage in symbollc and/or textull form. The wessage should not he affixed io the arker, since this is removed ton eastly (cf. the inscription on the Acropolls). Nor should It be applied to the arker (e.g., palnt) alnce this Is too casily scraped of or painted over. The realining option is that the arker isself should be engraved with the nessake.

Another point to consider Is whether the ietterina or syobols shoult be ralsed from or cul into the surface of the mirier. Most anilent Inscriptions are just that: they are cut Intn the stone or metal. Ralsed flgures are cenerally reserved for artistic work, i.e., rellefs. Cutting the nessaze into the stone created crevices in mich raln water could collect. leading to cnrrosion or, If it freeces. co etress. Howerer, the cholce of a destrable rock would atniatze the poteatial daege. Rataed letters. on the other hand, can

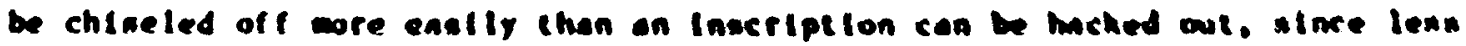

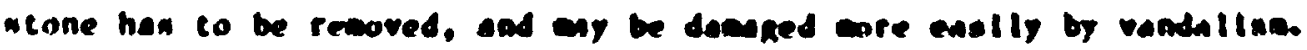

A finel and seall potat to discuss is the depth to wich the Inacription choult be cul. It ahould be noted that the depth could the cet by the poten-

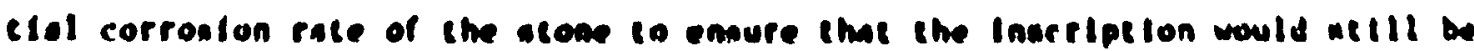
leatble after 10,600 years. For meropective, It obould be noted that anclent

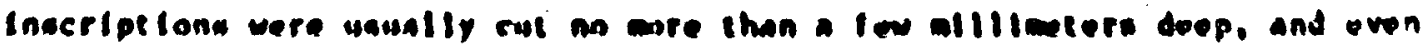

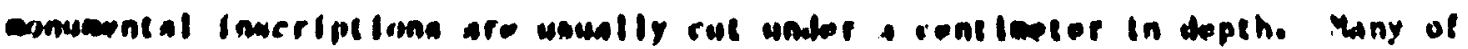

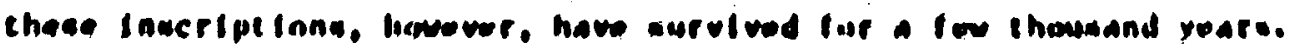

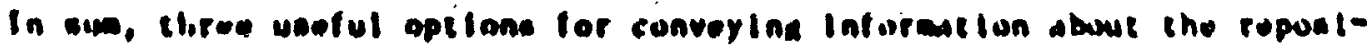
cory atce have been ldonetilied

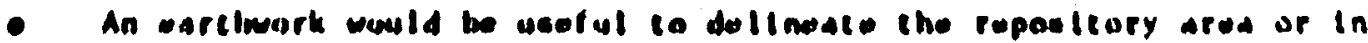
the whape of the lianardens aterial oyobol.

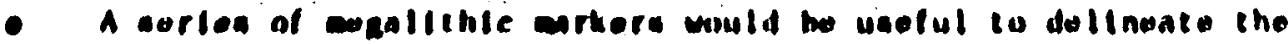
ropustlury area or In the ohape of the hasardous matortal uymbol.

- Inecriptiona un each of the cogaltiha mould the uneful to convoy

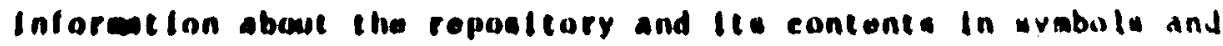
languagu on the eagallth liwell.

$$
87040 \quad 1077
$$




\section{2 MARKE.R SYSTHM DESILS}

The preliminary repository arker system design presented here contalns three a for components:

- A serles of monoltths defining the perimeter of the repostcory site.

- An earthwork in the fora of the hazardons uterlal warning syabl.

- A marker at the center of the site.

Ench cooponent will be discussed in a separate section.

\subsubsection{Perioeter Monoliths}

The disussion of this periseter wonolith falls Into two sections, the placewent of the arters and a deacription of the arter Itself. Several factors should be considered in placing the enthers:

- The disposal area (and buffer cone If lesired) should be defined uit'i reasonable accuracy.

- The opacing of the earkera should allow an investigator tu stand at one arker and see the next wither on elther side.

- A suftictent mobef of esthers should be used so that the placement pattern can be Identifled even if sowe enthere afe lonte

The perimeter rias of comolithe daflines the area to avold when drillink In ordar to preclude Interception a cantoler and betaglan part of the wate

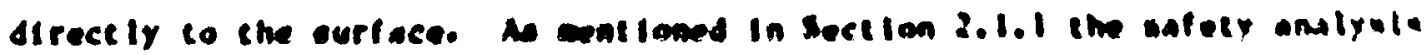

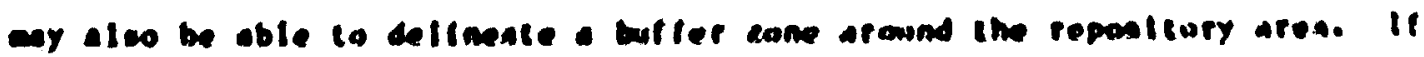

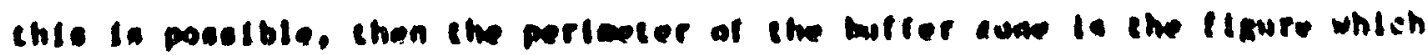
should be ouellined.

The nont tue tactore lateract and wase constdered in llath of the

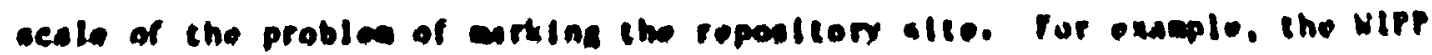

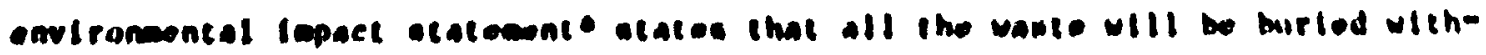

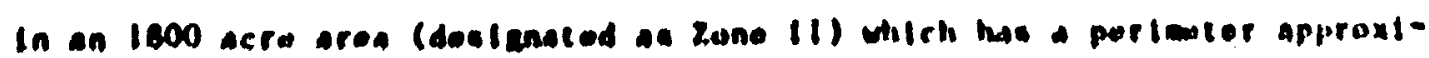

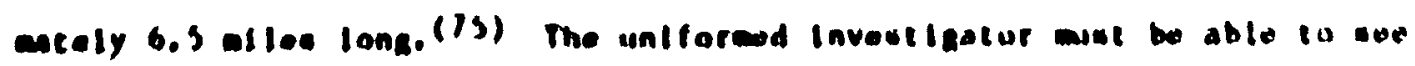
the noxt arker in elther direction when etanding at a matker in urder to

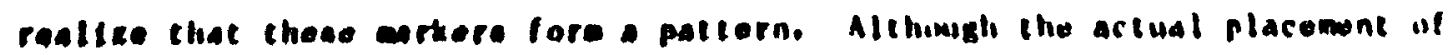

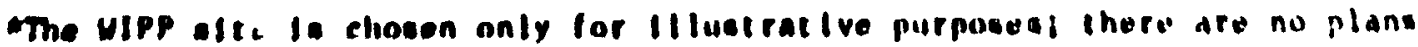
at preaent in bury high-level waste at that ollo.
80010
1078 
the arkers will be deterained by the topokriphy if the alte, a spactng of approximately 400 yards between then ay be suffictent. Given the helght of the warkers (cf. below), they would be dlacernible at these distances in a flat, unwonded terriln.

This suggested placcoent patern would result in 29 to 30 warkers beling used to dellneato the WIPP alta. A siallar nunher of stones are used in the sarsen circlo of Stonehenge, wich Implles that there will suffirlent arkers to reconstruct the pattern if snee of the stones are destruvad or carrled of $t$ in wueuns. As acntioned above, the plan of stonehenge ian the reconst ructed even though more than $a$ third of the stones have disappeared neer the lant 3, gon yearn.

The option of sioply ualng four atomes to art the rardinal mints of the area is not acceptable for several reasons. Firat, the scale is so large that the uninformed inveitlgator mould not be able to wee any of the nther arkers and so would int recogntee the area to awold when drlilling. Second, the Inss of any one aniker would destroy the pattern. Finally, with such a sall nuer ber of artera it in panelble that all of them alght be destroyed ot anves durlng the tite porind of intereat.

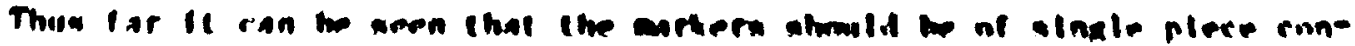

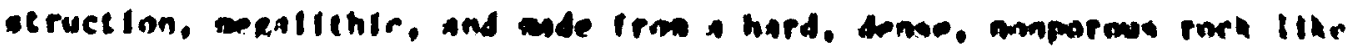

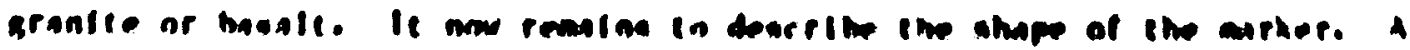

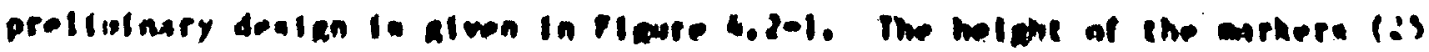

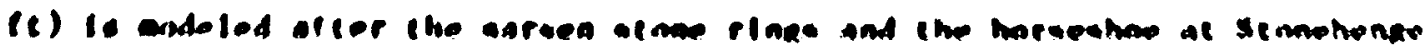

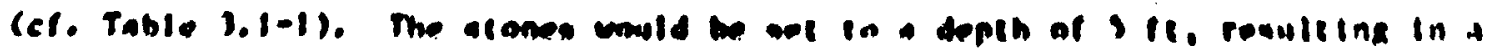

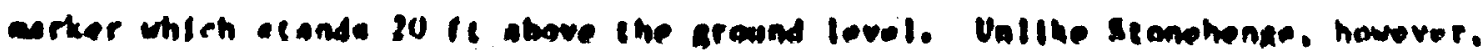

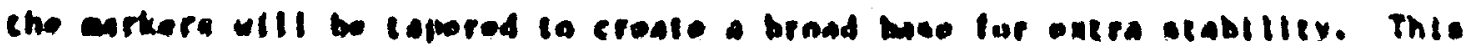

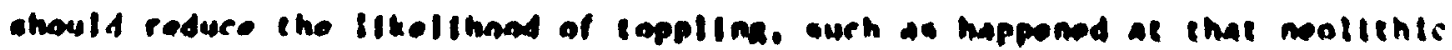

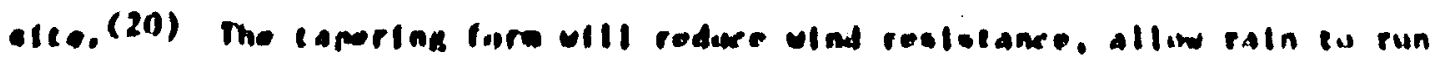

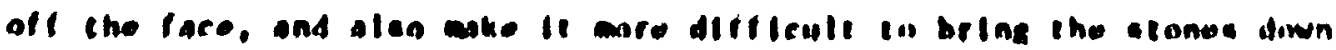

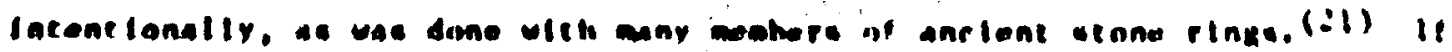

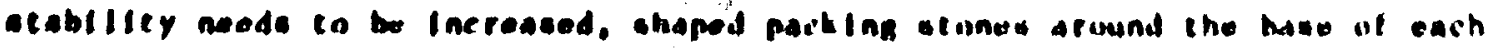
conollilh can the uned.

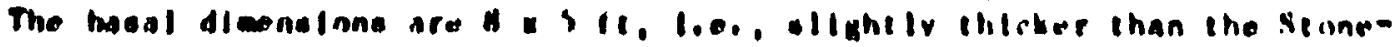

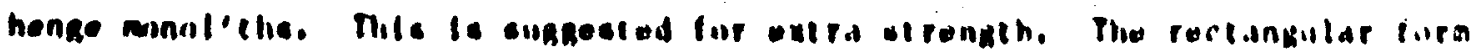

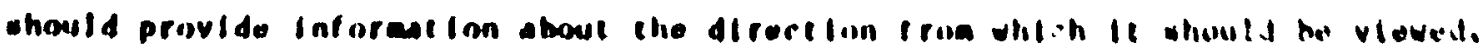

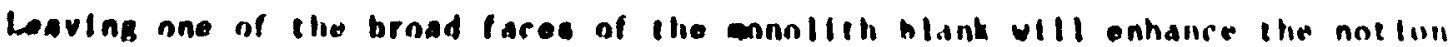


a) Pront

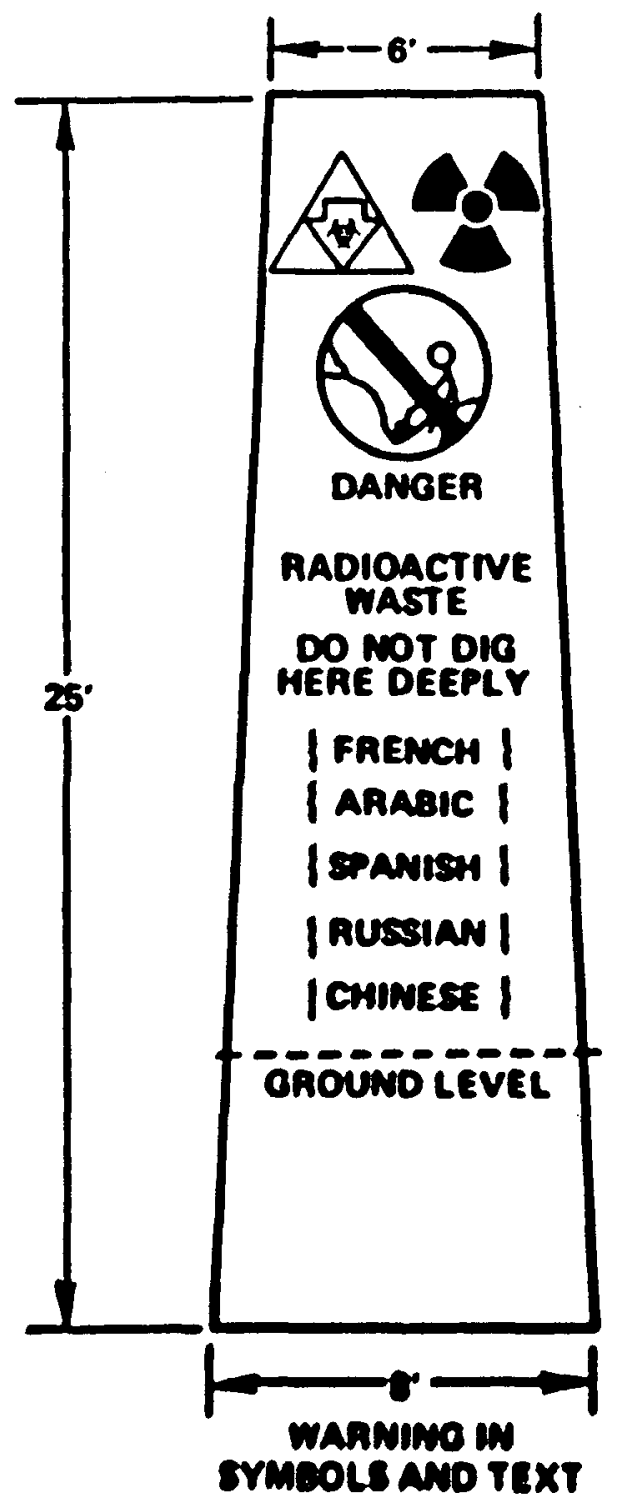

b) Side

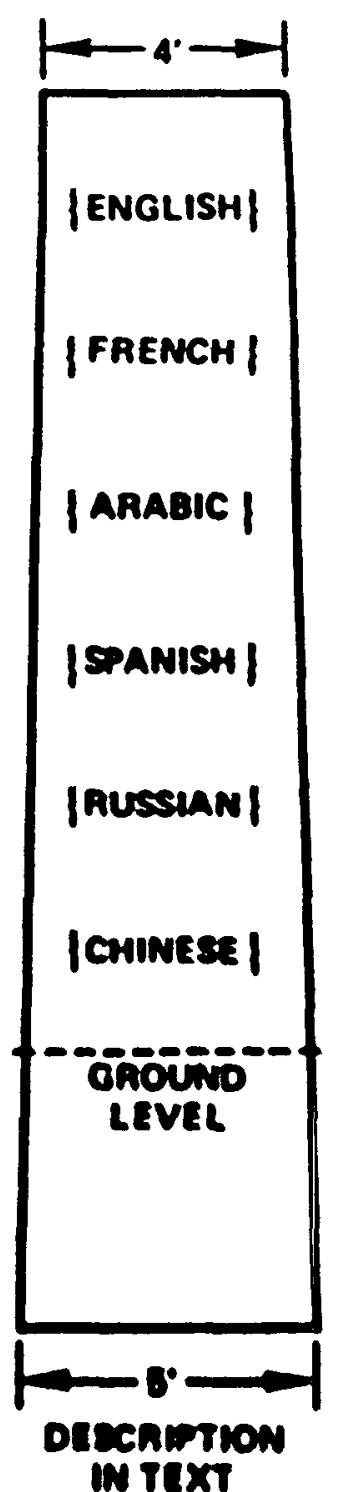

c) Side

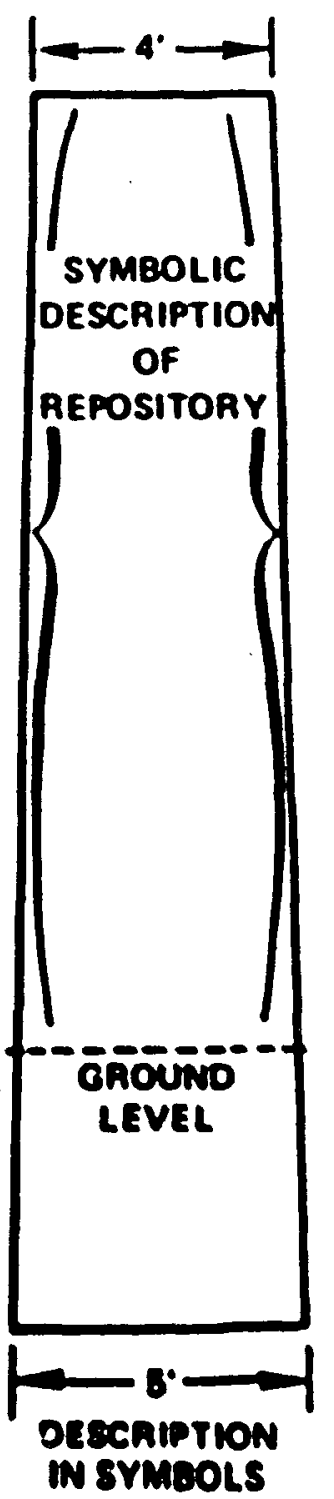

\section{rivere 4.2-1 perlepter Manollin}

of wich is the -front of the esomenent. Minglan the olfe with the carved

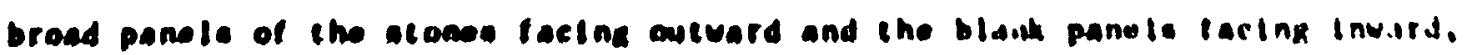

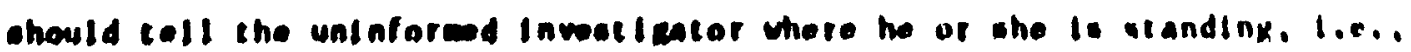
auteride of the repantiory area.

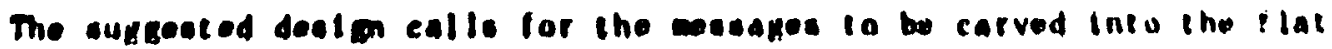

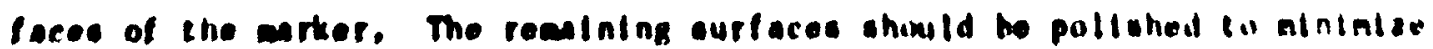

$$
80040 \quad 1080
$$




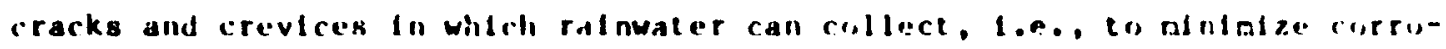
slon and deterioration. If wind erosion is a potential problen at a repository site, the msage can be protected by a ralsed band around the edge of the panel to bear the brunt of the wind dasage. (The facade of the treasury at Petra, Jordan is in wuch better condition than wost at that slte. It has been augrested that this is due to the fact that this tacade is recessed into the cliff walls.)(76) The messages carved on these panels wlll be fully discussed in section 4.3, but it should be noted that the syabol in the upper left of P1gure 4.2-1a is the hazardous aterial warning syabol developed by the HITF.

\subsubsection{Eerthwork}

If the dectation is ade that the repoation erters thould be visible from the alt and ahould call attent ton to the site, an earthrorth can be incorporated in the arter syatee design. The rety mature of an earthwork llalts the esount and cype of Information It cen convey: acking it in the forn of a hazardous waste syobol would alke the bet use of Ite lieltations. The earthworks of England are fonced by ualan the asterlal excavated from ithe ditch

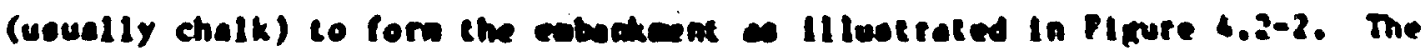
bank at stomehenge is 6 ft high and 20 te vide. mille the one at avebury me

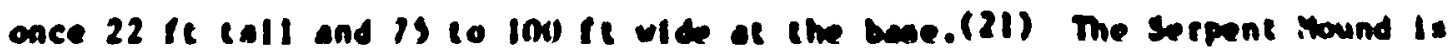
3 le high and 20 le vide. The slay body of the serpent covers a elone core.

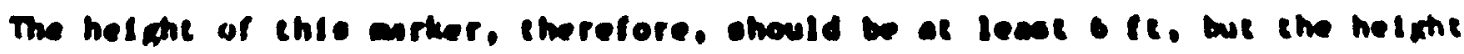
probably would be deternined by the auffece eroston pate at ine opectlle repus-

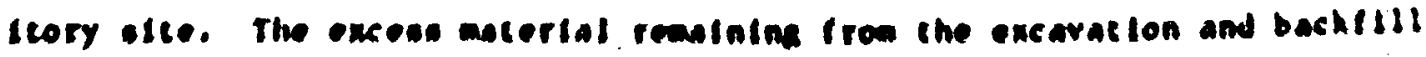
of the reponteory ceuld be wad in the formation of the core of the enrimork.

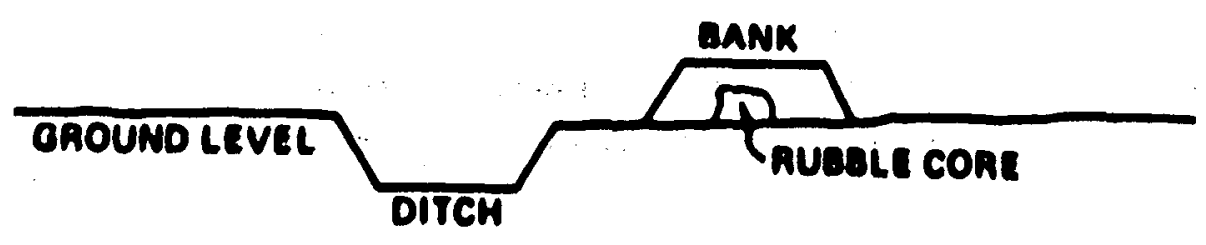

Plgure 4.2-2 Rebankent and Ditch Construction (section)

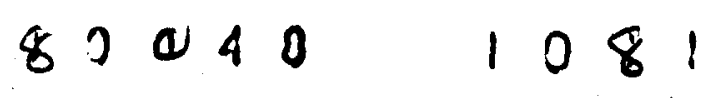


The vistbillty of the embinkment can be enhanced by parking lise tup us it

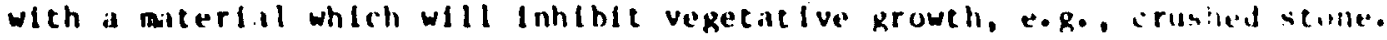
This change In vegetalion, as well as the original color contrist hetweon the stone and soll, would be quite vistble from the alt auch as ate the lisil lines. Other possiblittes include packing it with agnetic sand in create a agnetic anomaly.

Unltke the peribeter monolths, the earthwork has no definlte size requirements alnce it does not define a particular area. The size would he detervined by a tradeof between cost and the scale on which it will the viewed. The greater the scale, the greater the helght from which it is vistble unt Il the width of the earthmork is no Ionger discernible. Ising arihaenIoglcal examples as mdels. the bunk at Avebury ls a quarter of a alle In

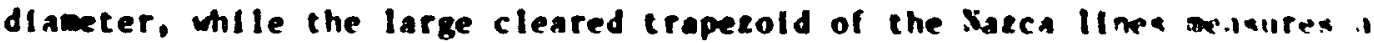
half-alle on Its longest side; an ewbonkwent within this slee ranke wuil he eppropriate.

It should be noted that tht component of the aurter system entalls the

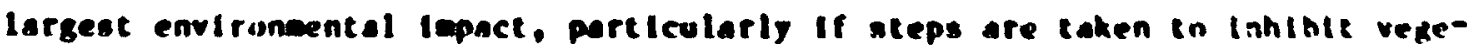
tation on the cop of the ebhankent. The peplecter momiltios umild serve to delineate the alte area, cam the miential Intrudera. and dearitir the ripise leory in more detall than 15 poselble to be done by an earthuotin. Ihe conoliths, hovever. would be septes of polats wen viened troe the atr and

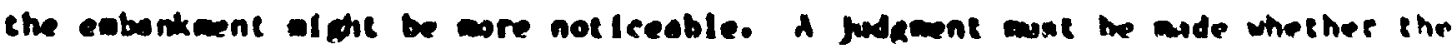

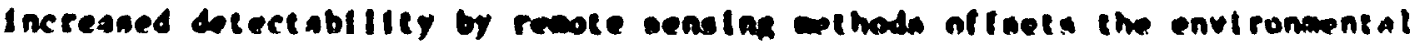
1epace.

\subsubsection{Incerlor Marker}

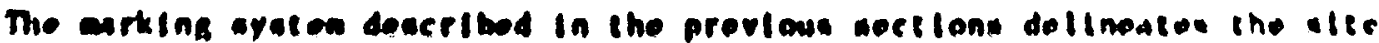

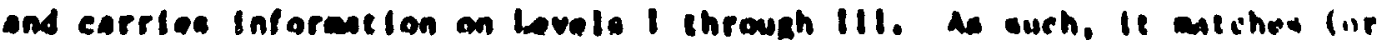

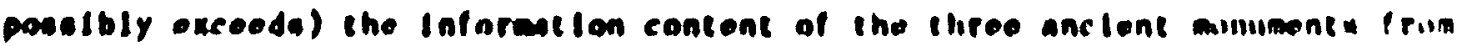

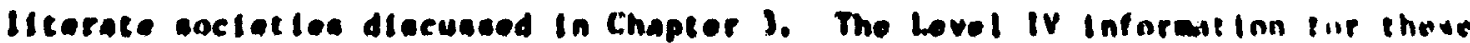

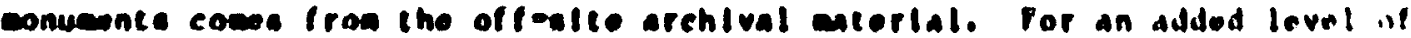

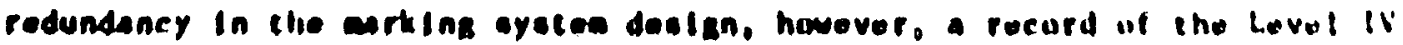
Inforation could be kept at the alte tiself. This is the purpuwe st the Ineertar enrker.

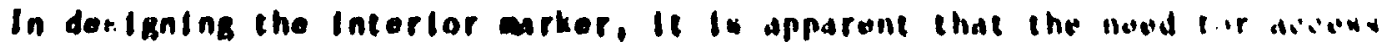

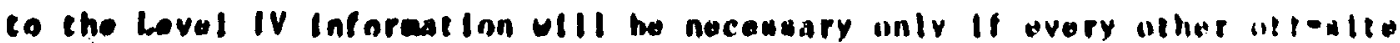


record has been destroyed. (lt is not within the purview of this paper to coment upon the type of cataclysm which could lead to this situation or whether suffictent technology could be regained after such an event within the t Ime frame of Interest.) The level IV Inforation, therefore, need not be Impediately accessible to the Investigator. The prellainary design for the intertor arker has the level IV information stored In an underground vaule, while the position and purpose of the vault is marked by a serles of monollths and a tumius.

A tumulus is the name for an anclent burlal bound. Here it refers co che wond of earth raised over a valt containing the Level IV inforocton. The vault in localed below ground to create a wore stahle environent for tis con-

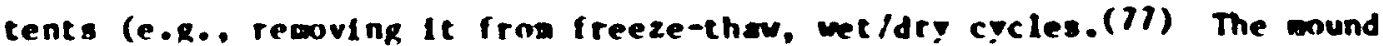
above it serves an an additional buffer hetween the conients of the vault and the fluctuating environment, as well as being a ourker.

In order to draw added attention to this marker. It ahould be placed in the cencer of the ste and arked by four wonoliths. A prelialnary destin for the twoulus and Incertor conoliths is given in Figure 4.2-3. The helpht of
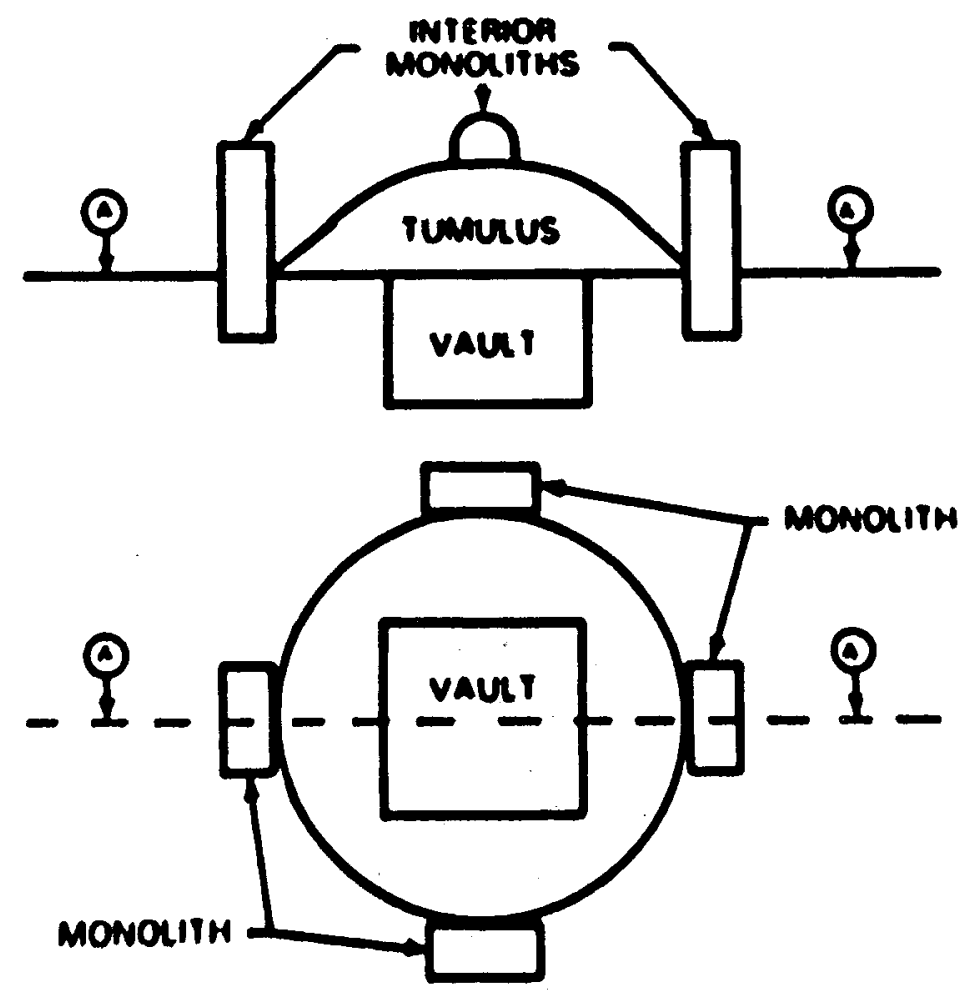

Plure 4.2-3 Section and Top Vies of Tumulus and Interior Monn!tihn

$$
8004 B \quad 1083
$$



ditferent Daterial than that which was used In the bulk of the collstruction. $(2(1)$ like the perieecer monoliths, they are tapered tor stability. The ditterence in the dessages on these monoliths and the perimeter wonoliths are discusbed in Section 4.3.2.

There is a possibllity that the saller size and tewer nuaber of interlur monoliths increase the likelihood ot their beling cartied of ur destroyed. The fact that these monoliths surtuund an obvlously non-natural wound of earth 18 going to draw attention to that eound. Excavation of that cound probably would occur before the monoliths would be noved or daanged. Finally, the monoliths are st11 larger than the "curce hown size" guideline for identifyIng aterials likely to be rawoved to wuseus.

Vaujt - The vault contains the level iv information. The ancient world, bowver, has not left an overly ude celection of durable eaterials wed for texts - papyrue, clay, and etome. There ate two cultures in the har bat were witing has a 3,000 rear bletory - Esypt and heopotente. The oldest tgrptian cexts are on stune; only a few freguente of paprow ourvive lron the

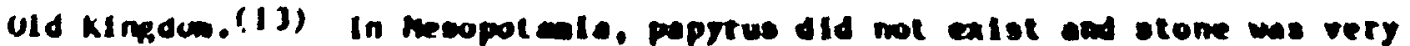

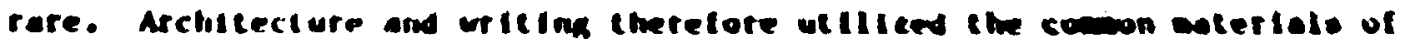

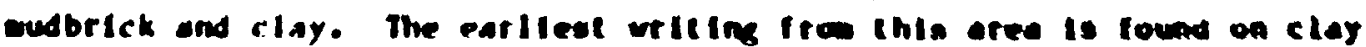
ceblets of the jendet mer pertod c. 3100-2700 8.6.170.79)

Popyrun ceren is have ourvited hecouse of the noture of its burlat

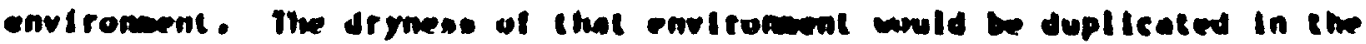

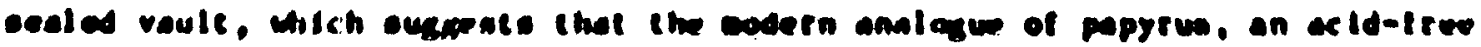

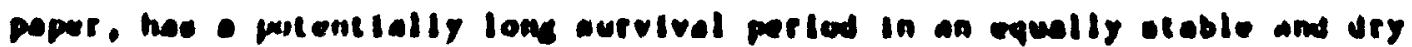

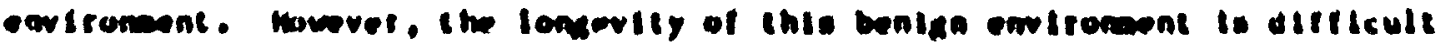
co entinge.

Tha meopotation conte opper te have ourvived becuse they reachad

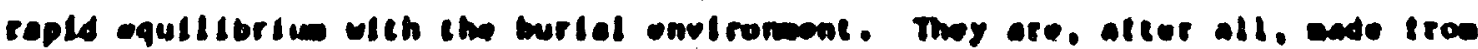

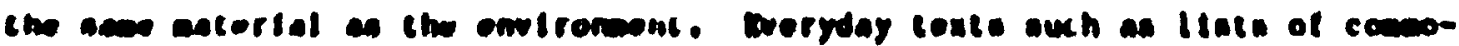
dicles and privale and butiane letere wie on unitred. but sunedriod

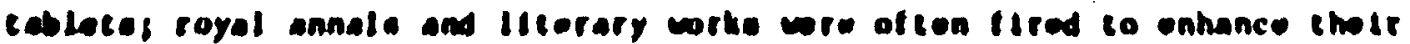

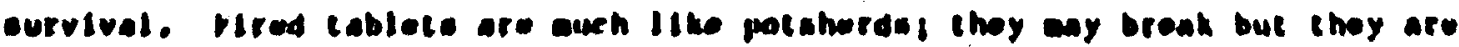

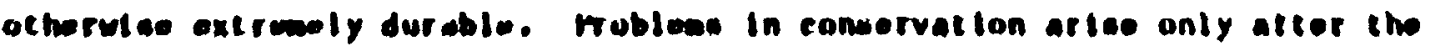

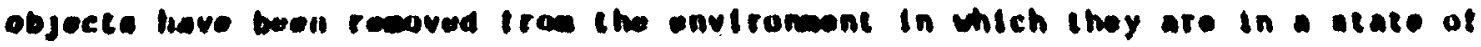
equilibritu. The durablitity of clay tabletw is alteated to by the b(X,OU)

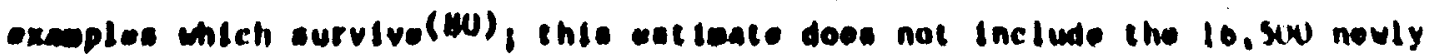

$$
80040 \quad 1085
$$


discuvered tablets and tragments trom the site of tbla in Syria.(bl) It should also be moted that these tablecs are tound in burlal clinales which would not be conducive to the survival of papyrus.

The archaeologlcal evidence actesting the survivability of stone has already been given in several places in this report. Stone and tired clay, therefore, appear to be suftable materials tor the Level IV inturmation.

The vault and 1 ts contents are the only non-replicated components of the repostcory arker systen. Unce opened, the vault no longer tunctions as an on-site aarker. Most of the contents would eventually be rewoved to the future equivalent of a library, university, or ouseu for sate keeping and study. This would occur even if the vault were initially looted. A parallel situation would be the Dead sea Scrolls which were originally tound by a bedouin child.(82) The vault should, therefore, Iso contain a request that the Information be transiated Into the languages in use at that tive, placed on durable materials, and replaced in an on-alce aarket. If that soclety considers the Intormation of oufficieat interest. It Is likely to be tran- lated and ade avallable to widet adience, wach like the worke in Anclent wear liast in Texte and The Licereture of axclent Expt. $(7.83)$ Neplacins the -updated verition on the atte is lees likely to be done. The woctely any nut conslder it neceseary to replece the Information. we the request wust be

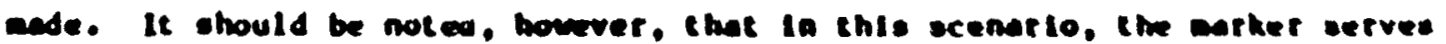
1ta purpoes by aking the infornation avallable to the public, and intitatins - an cycle of of -0 ite intornetion iranefer.

\subsection{Mareen nisencts}

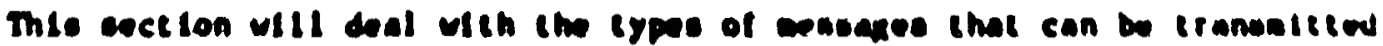

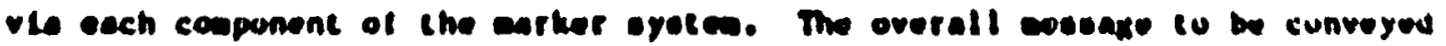

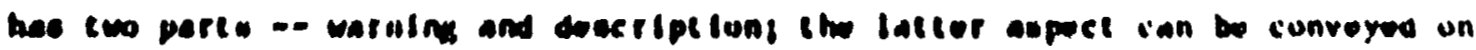

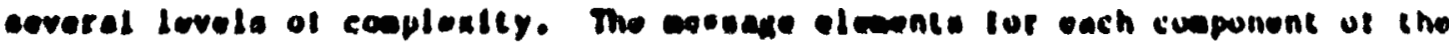

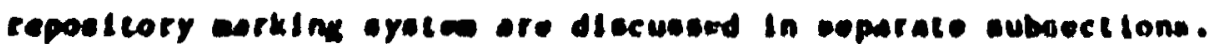

\subsubsection{Pertecter monalithe}

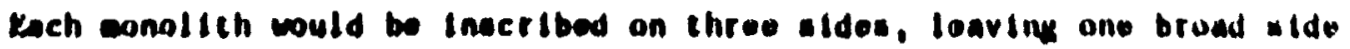
bleak. Wy placting each monolith so that the blank tace is eurned fliwards tu

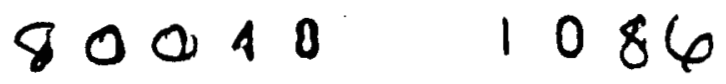


the repository site, the observer is informed atumt where he or she shoult be standing, t.e.. outside of the reposttory area facing the monolith. As menCloned carlier, the position of the wonoliths defines the repository area.

The front face of the marker (Figure 4.3-1) bears the warning of the site and the staplest level of description. In the top left corner ts the hazardous aterial warning symbol developed by the HITf. The syabol to the rlght of 1t acts as a qualifier, 1.c. radinactive material. This line can be "read" elther froa left to right or right to left. The syabol below it is pacterned

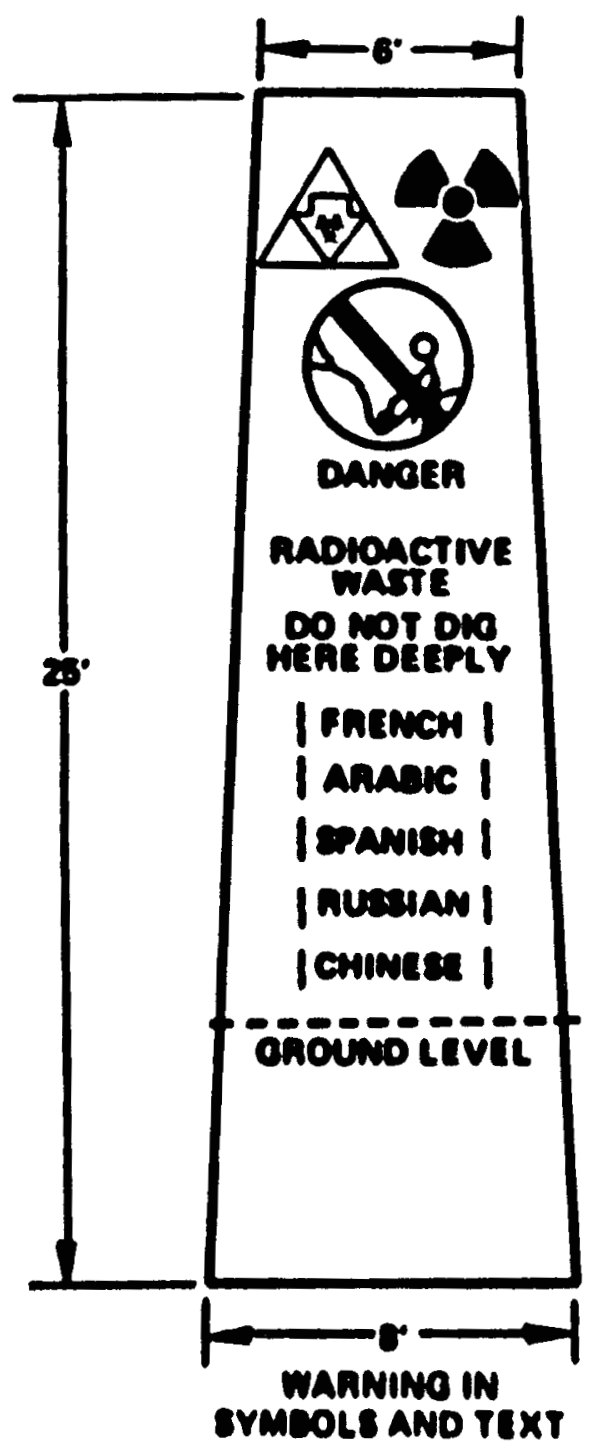

Plupre 6.1-1 Verteoler Monollin 
atcer the incernational driving signs. It shows a huan digking with a line dram actuss te. (This way be interpreted as that no dikfink should be dille at the site. but since we cannot convey the ditletence between surtace atid deep excavation In a single sipple sybol, It is better to cunvey the aute conservat tre wessage).

The next $1 x$ panels repeat this information in the $s i x$ langwages of the united rations. The use of six larguages increases the posslbility inat at least one of the will be recognizable to a number of people and redable by some scholars. The wording is delibetately siaple in order to facilitate its

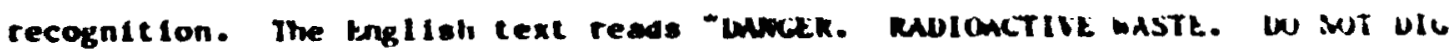
DLEPLY HELHt."

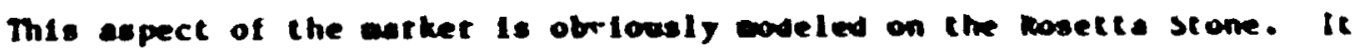
an be ergued that the amount of tine it took before the kyptian hierualyphis cext could be read (nearly 23 yeats after the stone's discovery) would mot be in cime to prevent interterence in the repository. This ixwotes the iaportent fact that one of the langunges was recognitenble and teadoble at the the of les discovery. To Illustrate, atief history of the hosetia stome is in

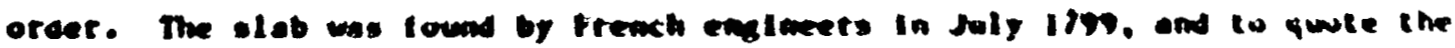

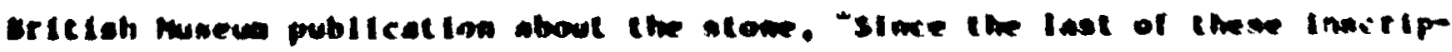

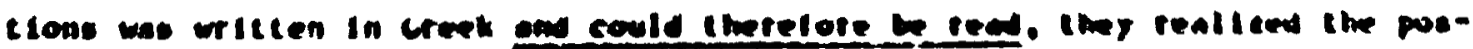

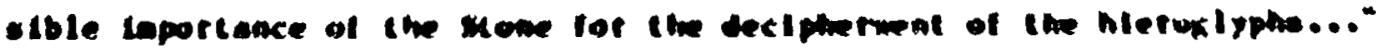

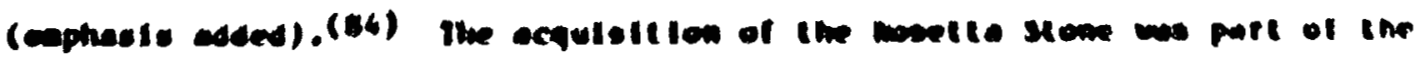

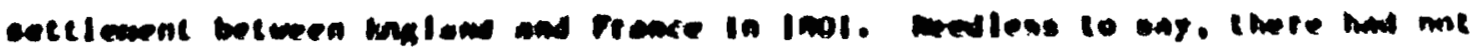

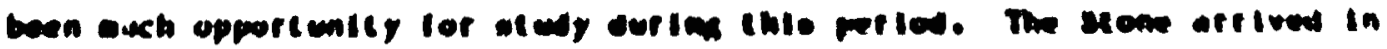

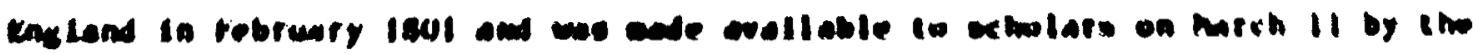

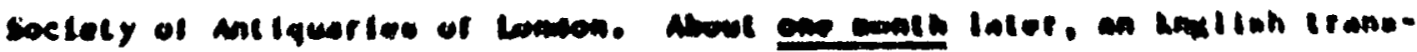

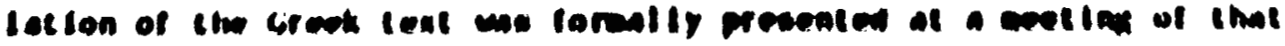
excesy. $(\mathrm{w})$

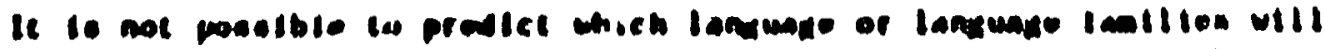

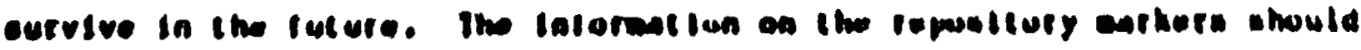

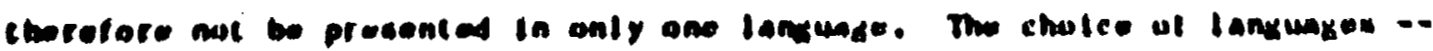

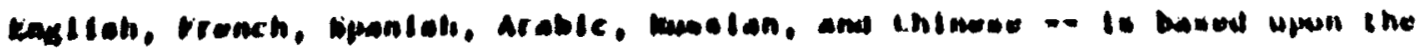

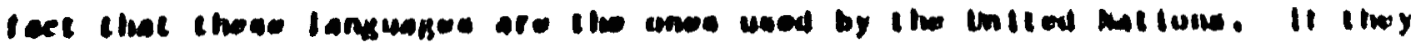

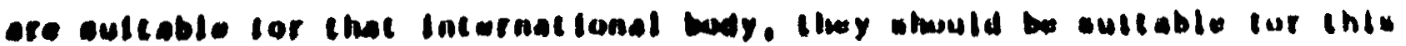

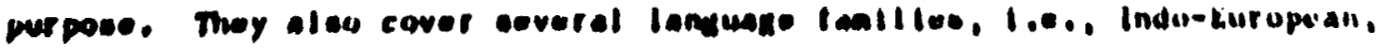
weriete, and initic.
80040 
One side panel of the marker is devoted to a description of the reposicory In symbols, pictures, and tigures. The derivation of a pictorial representation of what was done at the repository sice is not within che scope of chis repurt. Such a representation, however, should be included on this panel. In addition, diagrams can be used to show the areal extent and depth of the repository; an example, based on the wipt site. Is given in tigure 4.3-2. The areal extent and the positions of the peribeter and internal wonoliths are dram. The conoliths are not dram in scale since they would not be visible. An arruw earks the position of the wonolith which is being studied. This will help reconstruct the layout of the site even if several of the warkers are gone. The earthmok, If Included, should also be shown to Indicate its contemporaneity with the reat of the syted. (Fur exaple, we know that the ceeple at wxor once had two obelisk in front of It, were only
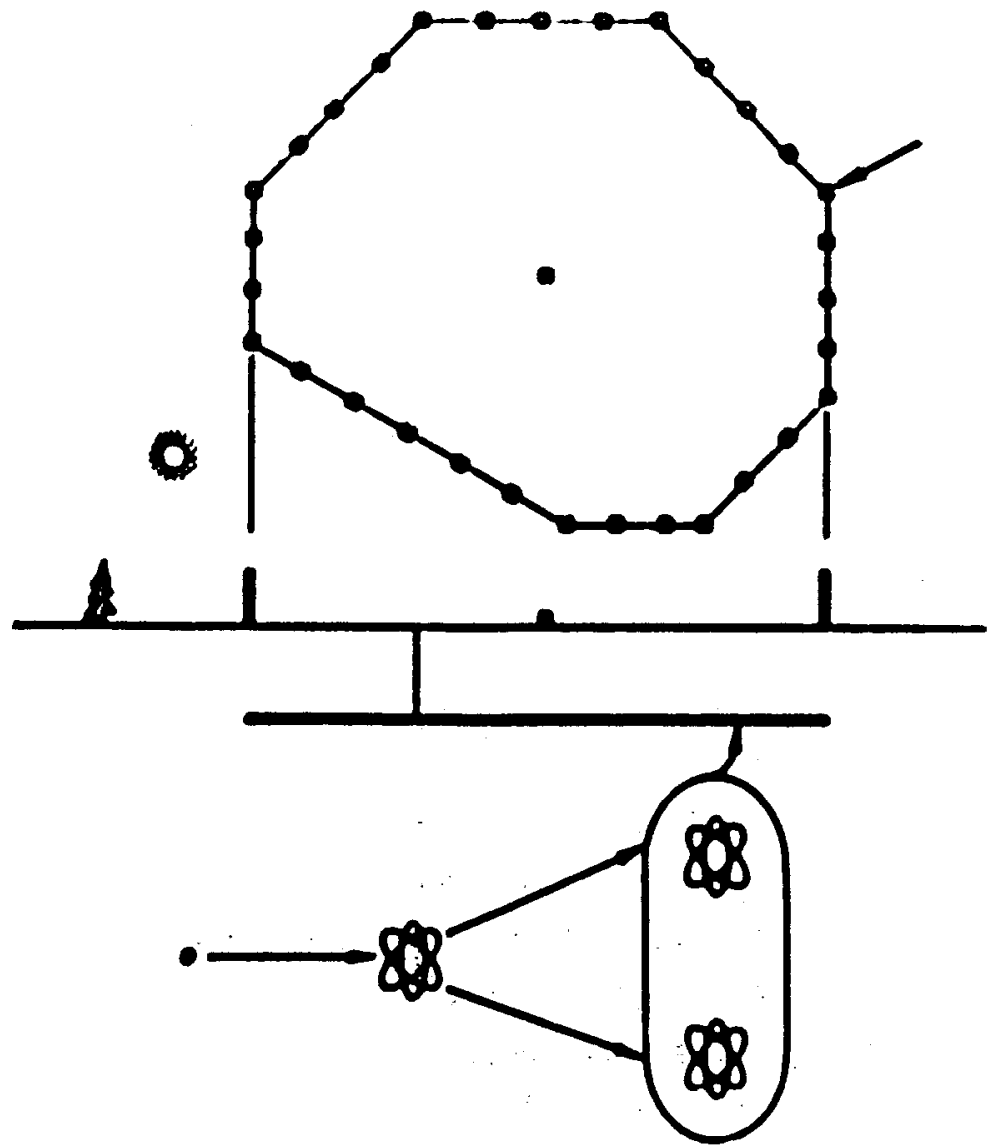

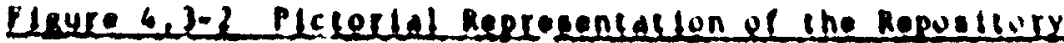


one now stands, because the temple is drawn un one ot lhe inslice walls.(85,86) It is not posstble to put a libe of unit length un the carker and then show it on the figure -- the ditferences in scale are too fireat.

below the top view is a cross-sectional view of the repository. The sun and a plant (here, a tree) define the ground level. The present design calls fur the wonoliths to stand to a helght of $20 \mathrm{ft}$ above the ground; this is approxinately 1 percent of the depth co the repositorv. The monultiths would not be imediately discernible it dram to scale, and that wuld deteat part ot the purpose of the plan. They are theretore shown out of scale in order to be visible. The ratio of the width of the site to lta depth shuuld, humeret, be accurately repreaented. The figures in the center should be circular ur trlangular depending upon the option chosen tor the central antker.

un the button of this figure is a scheatic representation of what is containce In the repusteuty. It show a neutron striking an atum whlin thell t1selons. As shown, the figure represents high-level waste; the disposal ut opent fuel wuld be Indicated by having the citcle include the atva wich fiseions as well. This general representation wa chween for lts eleplicity and clarity. The large muber of lsotopes which are lound in the waste pritcluden their representation, since they change in tiec (1.e.. Ihe representaclon would be Imaccurate) and the reprecental ion would be too epace-cunsualins chlle providing too litete informecion. Thet level of Informetion is epprupriate tor the core copplex Ievel, not here.

The other ulde panel is deroted to belef decciplions of the repustiury

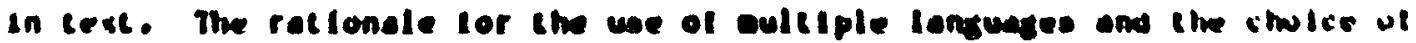
those langunges has beren decusend abeve. The ceat chould be hopt alaple.

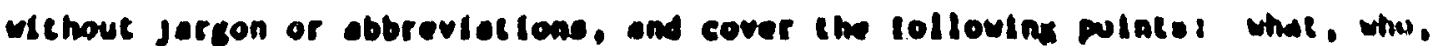

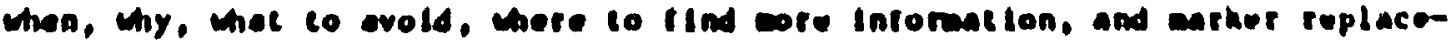

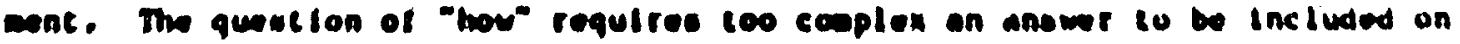
chle werker, bue whould be lacluded in the vaule.

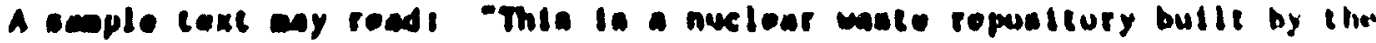
Uniled stater govermint in - The aroa of the reponteary in by

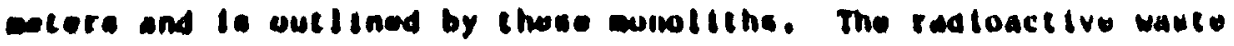

10 burled aetura down to put thin dongerous anterial tar away trum

cankind. In not drill netero deop. In not difll niw uso a well athout checking the water for radlanctivity. In iwt do allythilu which vill

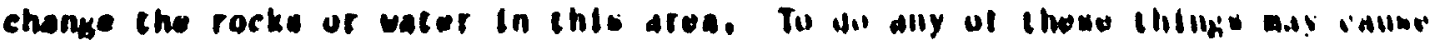


exposure of humans to radioactivity which gay result in cancer. More information is located under the hill in the center of this site and in government libraries. Do not destroy this warker, but replace it by using long-lasting aterials and languages coanon in your tibe."

\subsubsection{Earthwork}

As antioned above, the earthwork can only convey a liatted abount of information, l.e.. something is here and it is hazardous. The first is conveyed

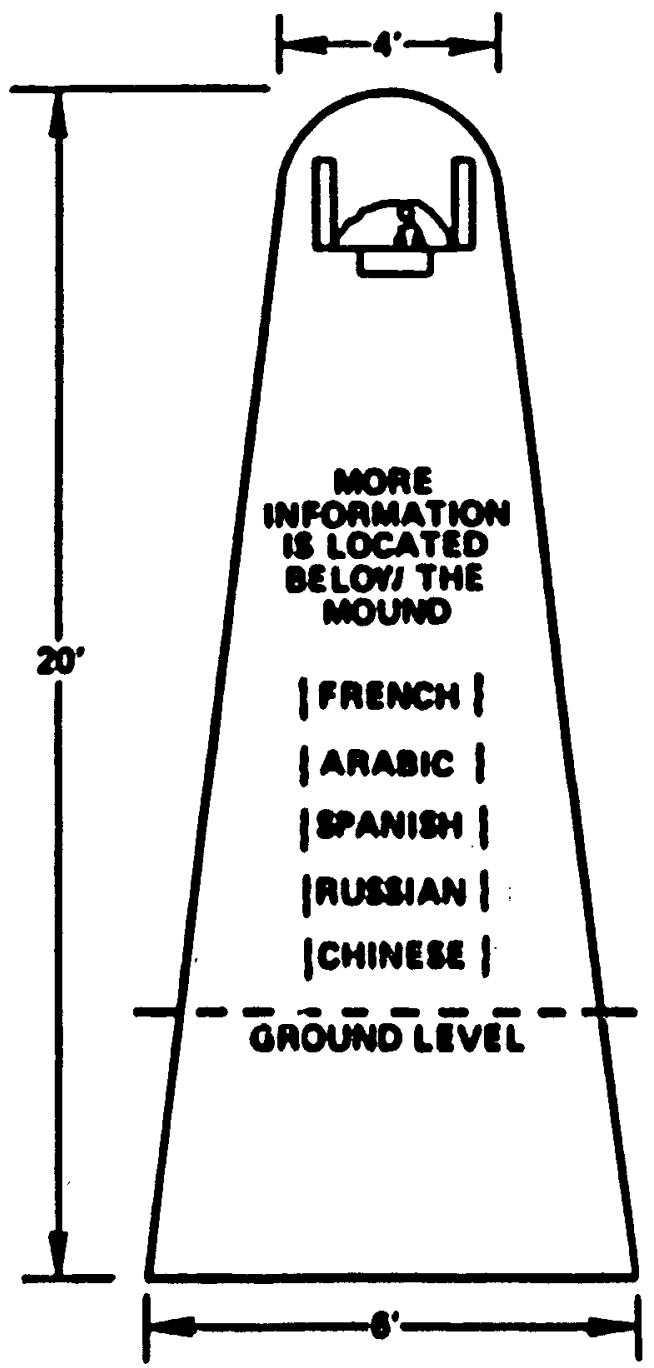

Pigure A.j-J Interlor Monolith

$80010 \quad 1091$


by 1 s very presence, whlle the second is told by tis form. It is, linwever, the one component whlch 18 a sultable vehlcle for conveylng a nexsidye to remote sensing devices. Suggestions may be ade for possible inclustons in the earthork to enhance 1 ts detectabllity (e.R.. magnetite), but these have-no erchaeological precursors.

\subsubsection{Interior Marker}

The wessage borne by the interlor wonoliths is siople -- wore Inforoation 18 located under the mond. The interior monolith (Fipure 4.3-3) does not bear the hazardous material warning sybbol, since there is mo danker fron investigating the vault. The figure shown, however, smectifes that the area to Invest igate is below the wound between the Interior wonollths. The oultiIIngual inscriptions explatn what to burted: aceple text In Ingilsh reads "More inforastion is located below the cound".

\subsubsection{Voult}

The vault contafin the Levi IV Intormetion and will not meed to be effective unt 11 all other of tate arehival Inforation is Iost. If the ste location is lont. the pertecter amolith will serve ta lint the concept of

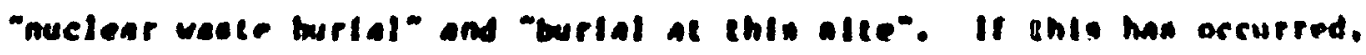

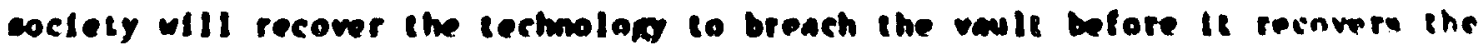
cechnoloky in intertere vith the repontiory epseten. In other wardw. inere is

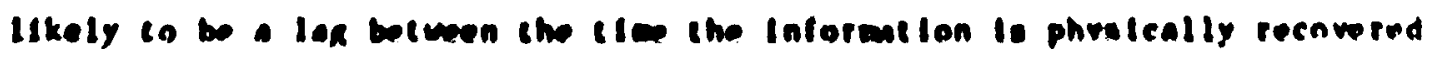
and the eles Interference could occurs this Iat would allow the potent int for the Intorantion in be dectphered and thus prowent interterence.

\section{$80018 \quad 1092$}


$\therefore$

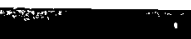

,

s

SUMMARY

The approach taken in this report is that the like hood ot human inter-

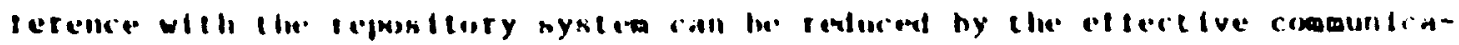
ton ut warnilis: messages. Fur this to occur, however, the message muse exist, be detectable, and be understood. A message can exist only after le has been ascertained what should exist (message definition). Where lt should exist (message location) and how long it should exist (message survival). There are tour possible levels of information tor the message: $(+)$

- Level I: Atcention-getter, ie., soothing is here.

- Level 11: Actentiongetter and warning, 1.e.. something is here and it is dangerous.

- Level I11: Masc Information, 1.e., what, wo, when, why, wat action to sold, and where to find wore information.

- Level IV: Pull record of Information. lIte.. plans, drawings. ewritowental manet statements, etc.

Archaeological data indicate that the utility of a Level 1 cerate without any

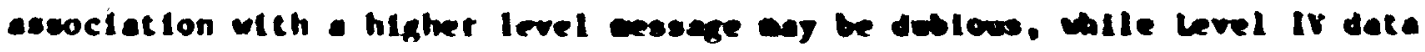
appear to be carried only by unites documents mich generally do not occur at - marker este. Incorporating all lout levels of information in the repository

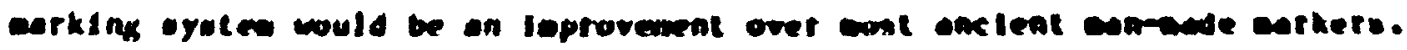

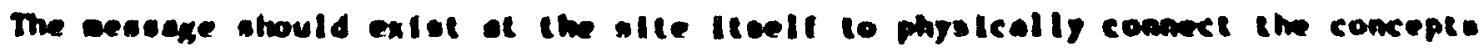
of "nuclear waste burial" an curtal ot this site".

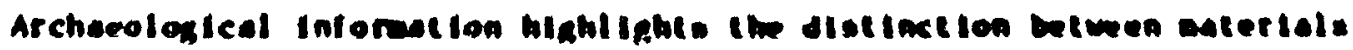

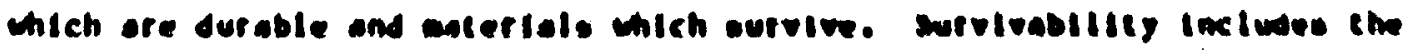

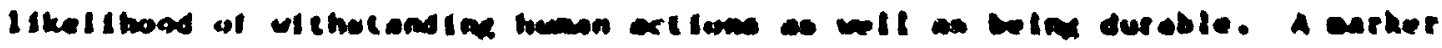

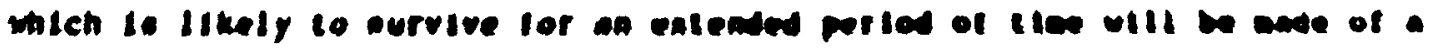

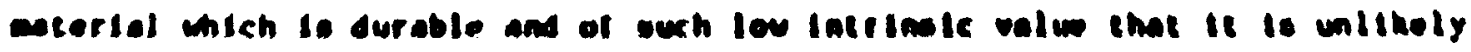

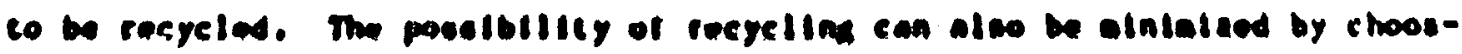

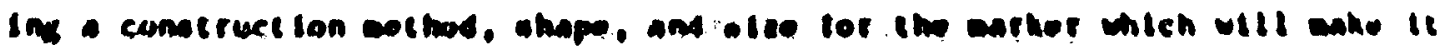

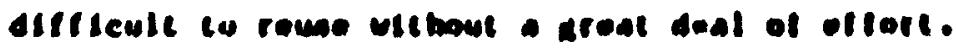

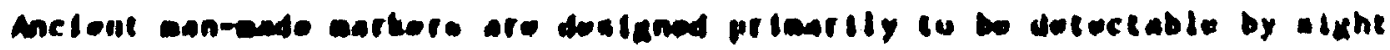

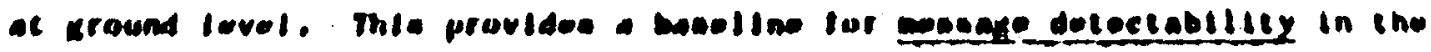

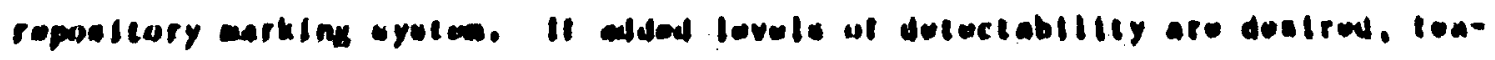

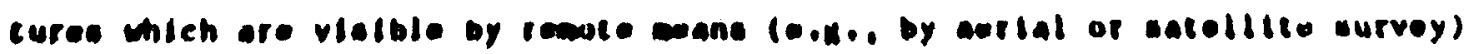

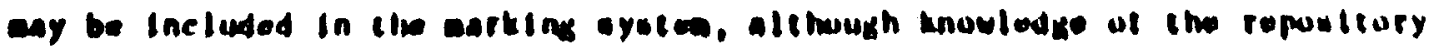

800401093 
and its contents at this distance will not affect the functionith of the reposteory system.

The third factor In the mirking system design is message comprehensibi!1ty. The message can be conveyed by three different means -- symbols. pictures, and languages. Archaeologlcal data Indicate that the higher levels of Inforation may only be able to be carrled across great changes in $t$ Ime and culture via urltten languages. The repostcory arking system should incorporate all three weans of convey Ing a message, and should ut llize a number of languages to enhance the likelthood that at least one of thea will be recug nizable to a nuaber of people and readable by sose scholars. This report suggests using the $\mathrm{six}$ languages used by the linited lations.

The prelininary arking system design presented in this report has three possible components:

- A serles of wonliths delineating the overall extent of the reposicory, or the repostion plus buffer cone.

- An optlonal earthork in the form of the hacardous aterial varning nyobol (included in the enthing ereter if visiblity or detectablitty at great distances, e.g., entellite, Is desirable).

- A central arker contatalne the wast detalled level nf Inforation. The Intormetion to not inediately avallable to an Investigator but is reedily ecceselble.

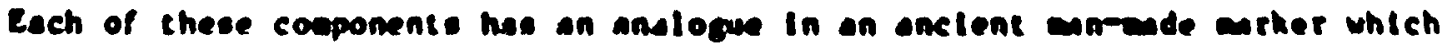
hea al ready survived for of least one thousand yeere. The information about

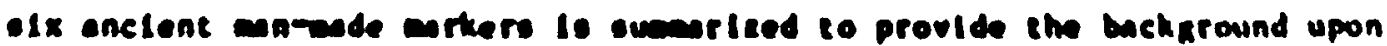
wich the deelan is meed.

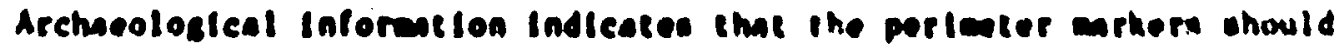
hove the loltowing charactertaticat

- They ahould be conolithice Oap plece construction ellatinater a alertale Intertece betwen the bondtng agent and component partu. a potential eree of corroeton. Thto olwo mans that the carkur will requitre mo active mintenanee.

- They eliould be apaeed wo that the noxt monollth in each direction can be eeens l.e. the pateera dolineating the alte la recognisabio at ground levil.

- The eonollthe chould be ade of a hard, coupact, non-brittle, non-porous, and relatively hompenoous alone. Matal is lon castly

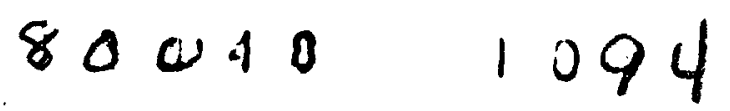




\section{$: 7$}

and lan trequently recyeled to use is i marker whloh should survive tor extended periods of time.

- They should be megalithle. An unusually large slze or shape for the arker will minimite the ease with with lt could he removed and reused in another st ructure.

- The monoliths should carry the first chree levels of Infurmition (attention-getter, warning, and brief description).

The perlweter monoltths will be sufficlent in nubber and carry enough information so that the areal extent of the repostenry can be ascertalned even if some of the monoltths are rewoved. Inscribing the arkers with symbols, plctures, and Information In mitiple langmages wll make this set of markers

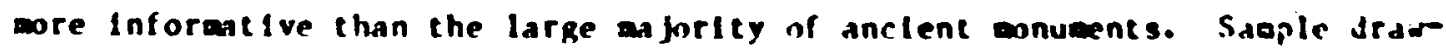
Ings and texts are provided in section 4.3.1. The peribeter arkers, then, contaln enough Inforation to jin together the concepts of -nuclest waste burtal" and "burlal at this ste".

The earthwork can carry only level I or level It Information (i.e.. attentinn-getter, or attent ion-getter with warningl. Its priac functinn will be to call attention to the alte from preat diatances, such as those ni aertal or satellite aurveying. Whether of not this is a requisite part uf the final reposttory arking gyaten design is a declsion witch reats with the humag Interference Tank Porce.

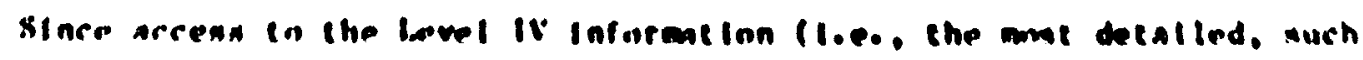
- environement impart we atmental will nol be mecensary unleas all nf the oftalte archival recorda have heen destfoyed, inta Information noed not be Imadiacely avaliable to an Inventipalar. For the Interlor arker. the Infor-

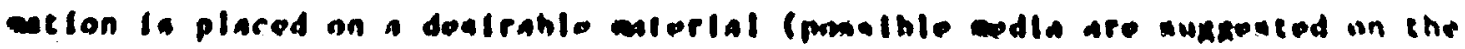

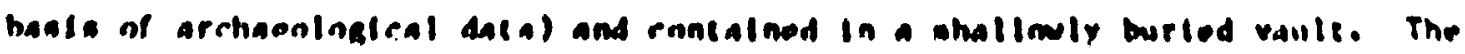
location of the vaule Io artued (and protectod by a anind uf earth which it.

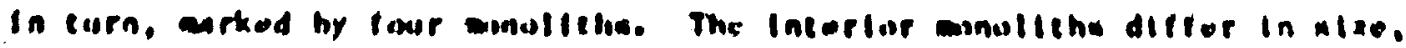

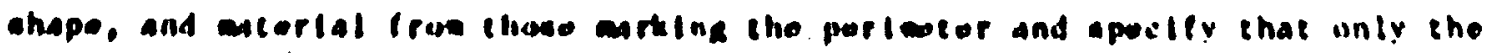
aren in betwoen thoe should be Invostlmated.
80048
$1095^{\circ}$ 


\section{RF.FFRF.NCES}

1. "Proposed Environmental Protectinn Agency Criterla for Radloartive Waste, "United States Fnvironmental Protectinn Agenry, is Federal Register, Section 221 , Noveaber 1978 .

2. Rocklin, G.I., "Nuclear Waste Disposal - Two Soclal Criteria," Sctence $195(1977)$, pp. 23-31.

3. U.S. Department of Energy. Statement of Position of the li.S. Departwent of Energy in the Matter of Proposed Ruleanking on Storage and Disposal of Nuclear Hantes (Waste ConfIdence Ruleasking), DEE/NE-0007, Apr II las?.

4. Givens, D.. "Frod llere to Eternlty, Commicating with the Distant Future," Untwerst ty of Washington. 1981.

5. Salth, N., "Roman Hydraulic Technologr," Sclentifle Aerican, May I9iR, pp. 154-61.

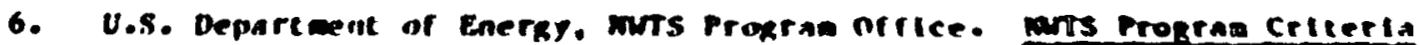
for Ceolosic Disposal of muclear Maste - Stce Performance Criteria. DOE/RNS-33(2), 198I.

7. Pritchard, 0.B.. Anclent mear Easern Texts; Princeton, 1969.

8. Mewbery. P.E.. El ceremeh 1, Londan, Inqh.

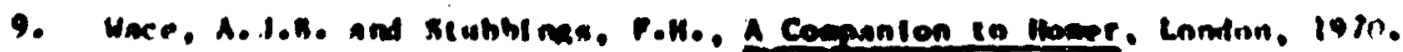

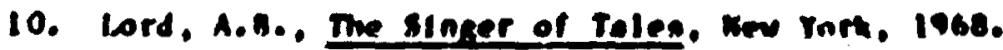

11. Pakhry. A., The Buraelde. Chleang, 1969.

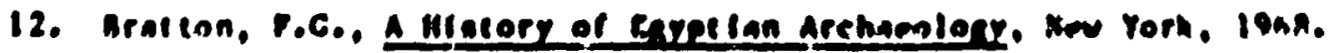

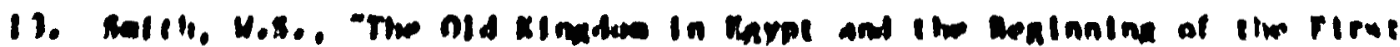

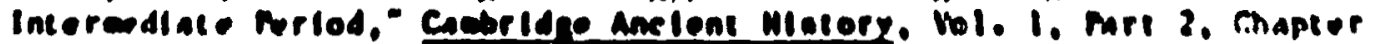
16. Cambride 1971. ppe Tos-dir.

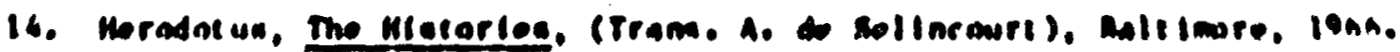

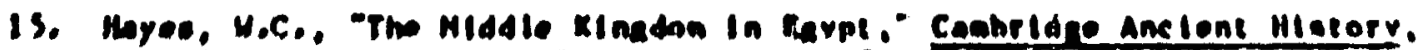

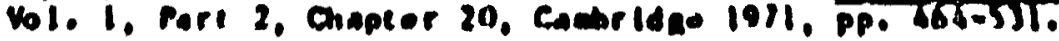

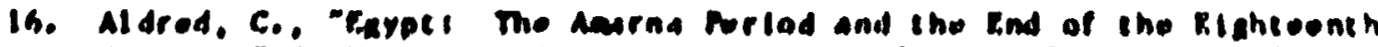

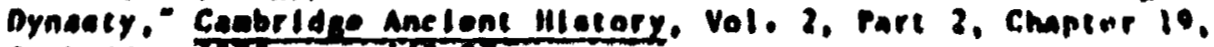

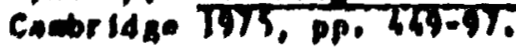


17. Faulkner, R.0., "Egypt: Fron the Inception of the Nineteenth Dynasty to the Death of Raseses III," Cambridge Anclent History, Vol. 2, Part 2, Chapter 23, Cambridge 1975, PP. 217-251.

18. Cerny, J., "Egypt: Frod the Death of Rasuses III to the End of the Twenty-First Dynasty, Cambridge Anclent History, Vol. 2, Part 2, Chapter 35, Caubridge 1973, pp. 606-657.

19. Hassan, Sella., The Great Sphinx and lts Secrets, Calro, 1953.

20. Atkinson, R.J.E., Stonehenge, London 1956.

21. Durl, A., The Stone Circles of the British Islee, Nev Haven, 1976.

22. Havkd ns, G.S., Stomehenge Decoded, Wew Tork, 1965.

23. Renfew, C., Before Civilieacion: The Radlocerbon Revolution and Prehistoric Eurape, Wev Tork, IST/3.

24. Hauklng, C.S.. -stonehenge: A Meollithle Cooputer," Eature, Vol. 202. 1964, Pp. 1258-61.

25. Howklns, C.8., "stonetrenge Decoded," Meture. Do1. 200, 1963, pp. 306-08.

26. Aekincon, R.J.C., "Decocer Misled," Meture. Nol. 210, 1966, Pp. 1202.

27. Atkincon, R.J.E., Koomhine on sconehenge," Aatiqulez, Vol. 40, 196h, Pp. 212.

28. Hoyle, P., "speculation on stonehenge," Aatleuler, Vol, 40, 19h6, Pp. 262-76.

29. Hoyle, P., "sconchence - a Eellpoe Predictor," palure, Wol. 211, 1966. pp. 456-56

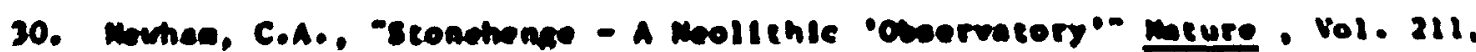
1966. Pp. 456-58.

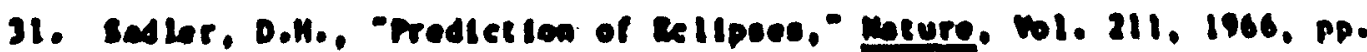
1119-2\}.

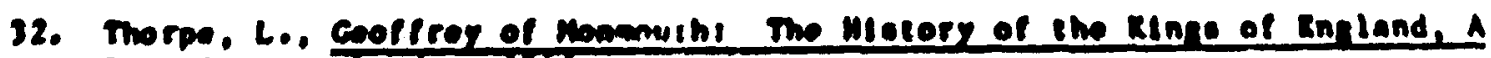
Tranelation, Tonba, THW.

33. Dantel, C., Nerallith in Mlelerz, London, 1972.

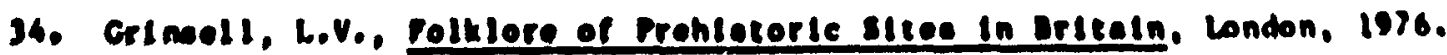


35. Hawklns, G.S., Ancleat Lines in the Peruvian Desert: Final Report for the National Geographic Soclety, Cambridge, $4,1969$.

36. Isbe1 1. W.H.. "The Prehlstorlc Ground Draulngs of Peru," Sclentifle Aserican, Vol. 239, 1978, pp. 140-53.

37. Broecker, W.S., Kulp, J.L. and Trucek, C.S., "Lamont Matural R.illocarbon Measur ewents, - Sclence, Vol. 124, No. 3213, 1956, Pp 154-65.

38. Ralph, F.K., Michael, H.N., and Han, M.C., "Radlocarbon Dates and Reallty," masCA Newsletter, Vol. 9, 1973, pp. 1-20.

39. Kosok, P., LIfe, Land, and Hater In Anclent Peru, Long Island UnIversity Press, 1965.

40. Kosok, P., and Relche, M., “Anclent Draings on the Desert of Peru, Archeeology. Vo1. 2, 1949, PP. 206-15.

41. Horrison, T., Patmers to the Cods, Mev Tork, 1978.

42. Hilley, G.S., Introduction to Anertcen Archecolor., Nev Jerwer. $19: 2$.

43. Rowe, J.H., and Mencel. D., Peruvlan Archerolon: Selected Reedinse. Palo Alto, 1967.

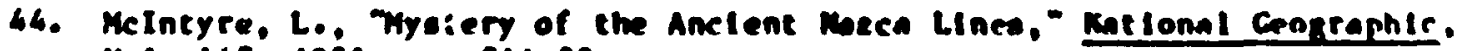
Vol. 147. 1975, pp. 716-28.

45. Davin. P.L., and WInelow. 8.. "Clant Ground Pigures of the Prehistoric Deserts." Procesding of the Anericen milesophical Socletx. Vol. Ins. 109. 1965, Pp. J-21.

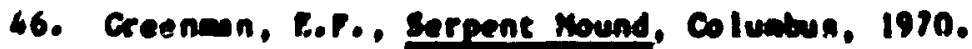

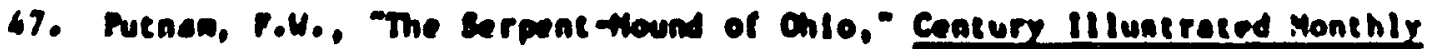
Hesezine. Apr II 18\%, Pp. $871-84$.

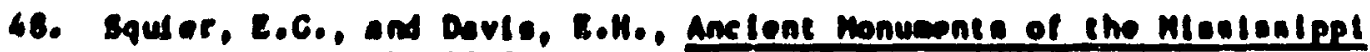
Velley. Whe York. $104 \mathrm{~s}$.

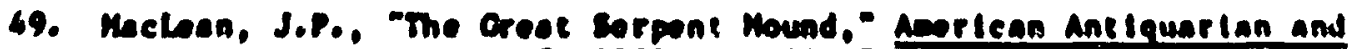
Ortentel Journal. Vol. T, IASS, pp. 46-67.

50. WIIloughby, C.C.. The somont Hound of Adana County. Onto." American Anehregolosdet. Vol. 21, 1919, pp. is3-63.

31. Travioa, J.. Pietortal Dietlonary of Anelont Aihens, Nov York, 1971.

$$
80040 \quad 10 \% 8
$$


52. Rossiter, S., Greece, The Blue Gulde, London, 1973.

53. Dow, S., "Andrews of Cornell," Cornell Aluanl Nevs, Decenter 1972, pp. $13-21$.

34. Robertson, M., and Frantz, A. The Parthenon Frleze. London, 1975.

55. Houras, C., "Testing Time for The Acropolls Momuments," Stone Industrles, Vol. 14, 1979, pp. 22-26.

56. Me1ggs, R., and lewls, D.. A Selection of Creek Historlcal Inscrlptions to the End of the Pifth Century B.C., Oxford, 1969.

37. Seccnd International syopostue on the Deterloration of Bullding Stones. (Achens, 1976), Athens, 1978.

S8. Cell, W.E. , The Great Wall of Ching, New Tork, 1909.

59. S1lverberg, R., The Great Mall of Chine, Hev Tork, 1965.

60. Fryer, J., The Great Wall of Chine, London, 1973.

61. Neechan, J., selence and Civilleation in Culna. Canbridge. 1934.

62. Latel wore, 0., Inner Aelen Frontlers of Chlan, Nen rork. 1931.

63. Ias, P., The Purple cerrier, London, 196n.

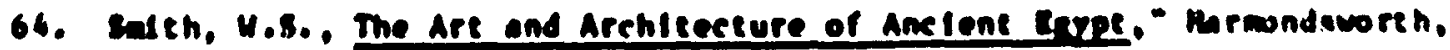
1958.

65. Clab. P.V., The sor Popple. IImace, 1969.

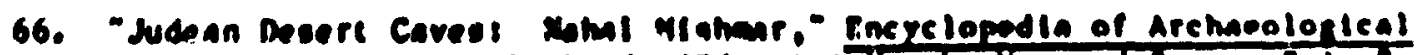

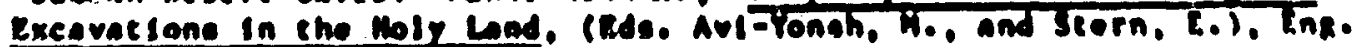
d. Vol. TII, servestes, TSti.

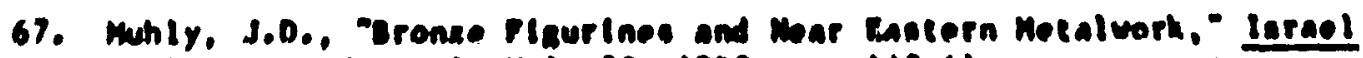
Exploration dournal. Vol. 30, 10A0, pp. 14B-61.

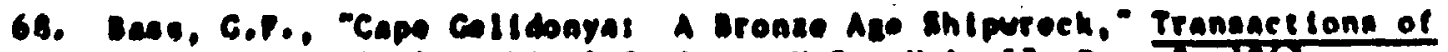
che imertean milosophicel soelesy. M.s.. Vol. 37, Part T, Twh.

69. Plonderletith, M.lo., and Worner, A.R.A.. The Concervation of Antleutities and Worke of Are. Oxford, 1914.

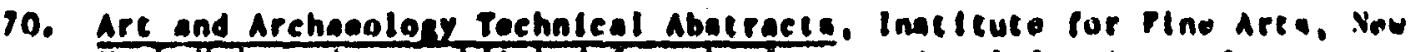
York Untvaratiy, pubtlohed Tor the Intornat lonal Inatleuto for

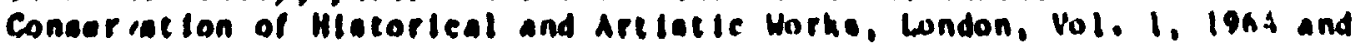
aubequequent veara. 
71. Thoupson, D.L.. The last City of Antinous," Archaeology, Vol. 34, 1981, Pp. 44-50.

72. Lewn, S.2., and Carola, A.E., "Scanning Electron Mlcroscopy In the Di agnos Is of 'Diseased" Stone," Scanning Electron Microscopy. Vol. I. 1978, pp. 695-704.

73. Helken, G.. "Pyroclastic Flow Deposits," Aeerican Scientist, Vol. ni. 1979, pp. $564-71$.

74. Bateman, C.A., Crawtord, V.E., Dalen, G.F., and ha feuskl, L.J.. Preservation and Reproduction of Clay Tablets and the Conservation of Wall Paintings, London, 1966.

75. U.S. Departwent of EnerRy. Fimal Enolronmental Iapace Statement Waste Isolation Pllot Plant, DoE/EIS-0026, October 1980.

76. Broming, I. Petra, Lonton, 1974.

71. Dowan, P.. Congervation in Pield Arrheolokg. London, 1970.

78. Frankfort, H., "The Lat Predmatic Perlod in cabjionia," Cacbridse Ancient History. Vol. I. Part 2, Chapter 12, Cobsidge, I97. Pp. T-92.

79. Opperhe10. A.L., Aaclent Mesopotante. Chirago, 1964.

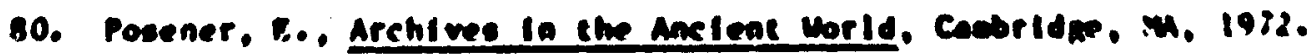

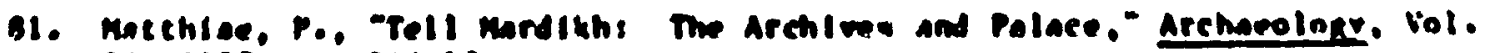
30. 1978. pp. 246-33.

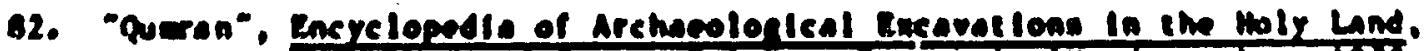

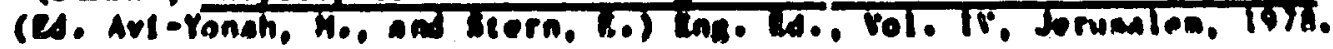

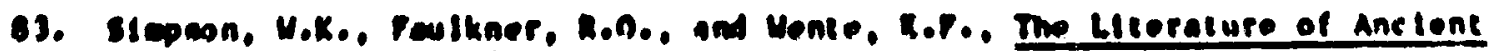
Exyes. How Mana. 1973.

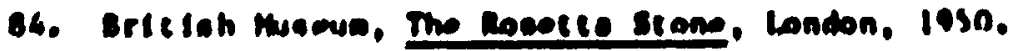

85. Murray. M.A.. Exyetian Tengles. London. 1031.

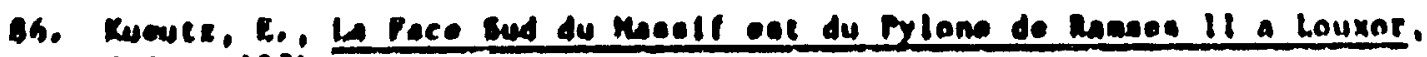
calro. 1971 . 


\section{DISTRIBUTION LIST}

acess marancan inc

a s. autass

a sratici

Mabaua detr of enmer

CAMUROY MCDONAIS

anwha state Golocxal suavr

tructiont vatmer

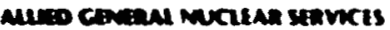

P1. mancenacte

are-couners

GARnCK I. SOUOUTY

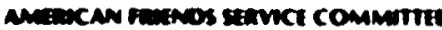
whlian Re molos

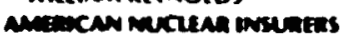

Dotru sertrmay

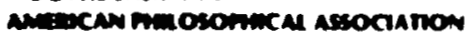

BONN OCONinom

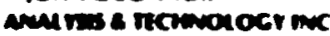

1 Marove

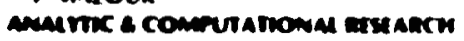
are

- sacar

Anvip encreaness me

Kunar a nullaws

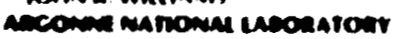

al wer ft inve

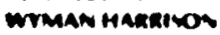

I MONAMD AIIIII

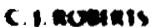

Mantin wit?

nenarions: sitinaria

arecentiansu come

M. P. commin

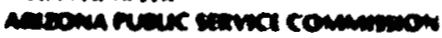

cinar w. entrim

Acrome state comberr

pacir enautit

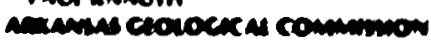

misam V ware

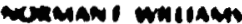

arime o. corve wre

arrva crat inn

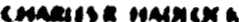

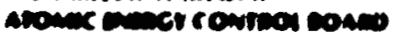

11 mantara

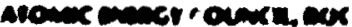

mor ruterini

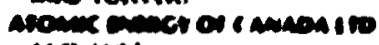

no iven

ancrivin

- concini

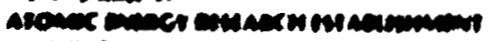
amina

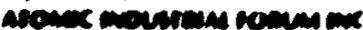

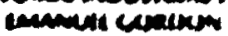

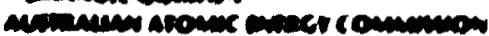

mocos stres

meremalion wande

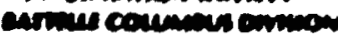

apowi incomin

Milere ans

cromina an encm

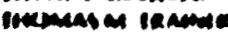

crentina valls

cand cons

recumeass cava

orose canisus

o i exun an

ilü I Iancom

e c icrimalim
I ITRNAT

I IUI M.PARA

RIC HARU) ICNIII

CLChtil mational inC

GIRAIDI PAIAI

cicosim ceocosecm onnst

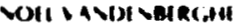

etmoix melo inceretemc cone

mil cirallay

CMarits a ronls

mominc pacie

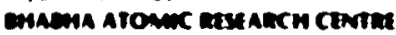

- sucvonas

- I tmonas

mack 8 vatce

w. Now rovisyon

cotinc encenitidinc and construction coment

Q e camens

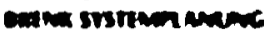

11 10 tos

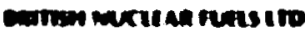

a a ins

mocomaver wationa lacomator

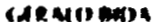

DONABI cian

a t isain

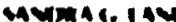

- n int

now $4 \times 1$

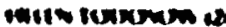

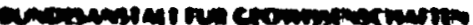

Colocmecin

monall I atcia

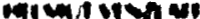

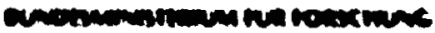

rowe nne aners

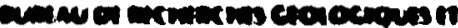

consming

mant wat ing ins

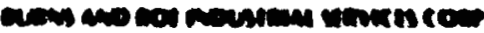

a vin andexi

$6 \sin$.

cont on sure.

cenars awerest

toren satits

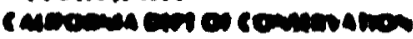

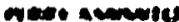

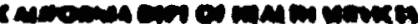

encrate somes

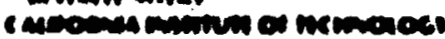

istor 1 unte

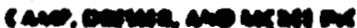

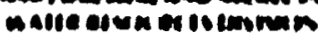

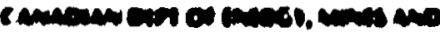

niveres

a nima

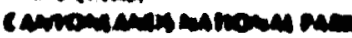

atere pare

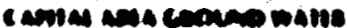

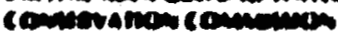

a in ei at is

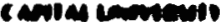

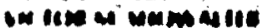

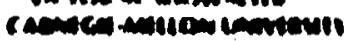

mina neve

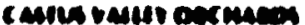

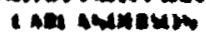

ravera eavi camenallom

Amocroman wo

11 S4aII

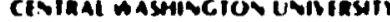

IR tII liuk iny

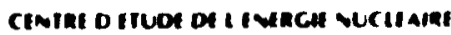

RI VI HERINAS

Centat o'monmatmont ClOGOCKOL:

(AII) AI) IH WIRN,

$\cos n$

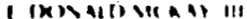

Comm-aukitan sistems in

Roven I in "l

Cmans ascociation bon sound ENEG

I A vita fll1?

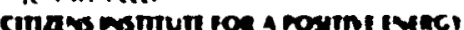

nonkt

inmas 41 or

cuanc Converm

naty inave

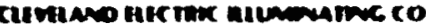

calis. Aits

cononabo crocock al semer

nen w an :

conomapostmoon on wests

n in sini ili:

comer nevt smme councu

calmis rusmi num

conncticet sean biranturet o

mantwingers

vinuter eting

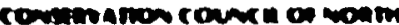

cancion

inw vilut

conem anoxinens

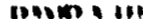

converes now

14041

com ere

ilvinnims

cemate wantingm

tom nom

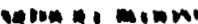

In tw o wenets

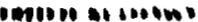

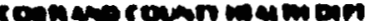

1. in v

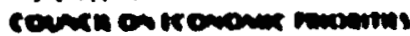

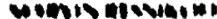

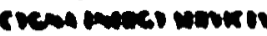

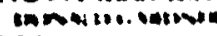

ath

ats I Atow!

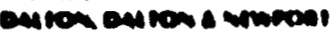

newe inatenow

obu sel ill

carros aming

notio cermins

winis on

chamen lltis

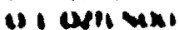

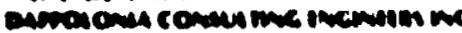
Int trandin

cov bement

cowe nowers

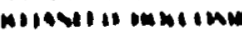

atien atrotis

cot vin eint

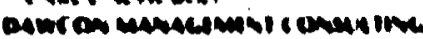
verust

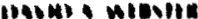

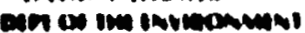

1111 


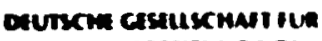
wioceract ameritenc von haval Min IIIMANh

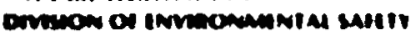
arsench

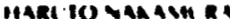

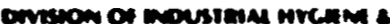

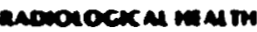

Hay s boxas

onavo bucrites and constaucioms

Aiv ani

pua unmests

Imomas Darts

oum croscina com

whe cetcinis

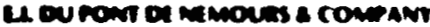

oonnd t contxon

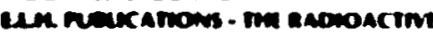
encmenca

ItMANOI HIMava

en ponmen ascociatis me

t. comson

Ci romison

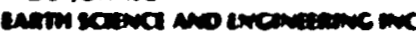
iou maxk

cast canoum unmintr

strenve Matern

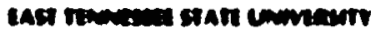

Mex MAIt R. Samin

ansco rimo:s tur

runin sents

BArmomo H Un

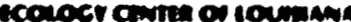

coss vmo int

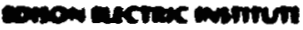

a I Stancomo

os morran me

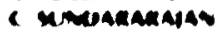

ce corime min

cronct e inve

a to rucranas

chanc anders

I 14 rumes

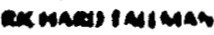

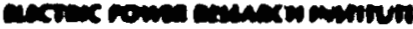

Corame cuarm

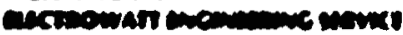

u valas

men

A $\vee$ mow

and ninats

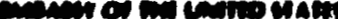

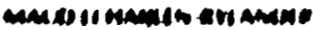

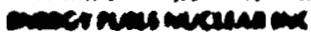

ocon an enenem

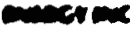

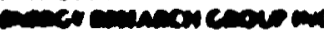

manc conomintus

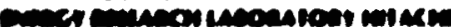

10

Marcios rement in

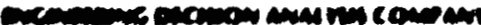

$\rightarrow$

coenument

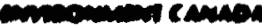

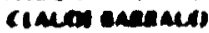

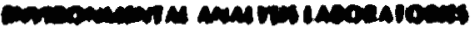

con

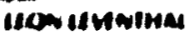

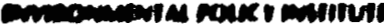

bavo an claks

ICAO ami i at

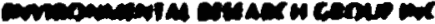

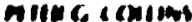

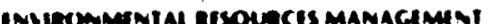
inc

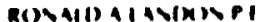

emveonmen comint

acedac. Avinas)

ocilanis

In conmt thminomuma

manacamint councin

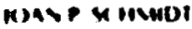

Iarte mastan me

I Cant stron

vall niteve

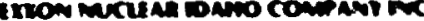

- amesta comenat

eocies inver

n. ater

Tomets verale

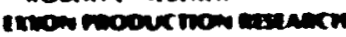

catre un arvent

in

uriomont

in non and arocatisen

cmi I cmarn

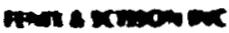

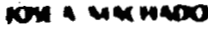

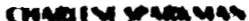

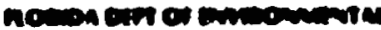

eronaturn

manem ich onst

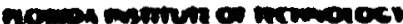

consens a strisio.

nomon rome strem connem

iname romento

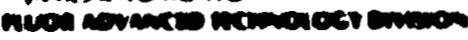
cones on cumint

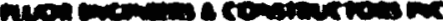

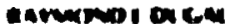

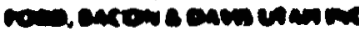

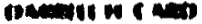

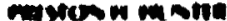

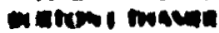

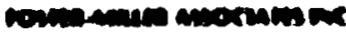
mingt Pase

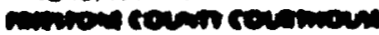
and counans

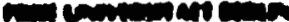

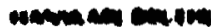

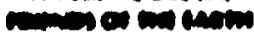

con menesin

cine raving

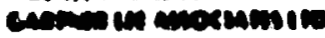

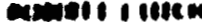

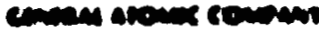

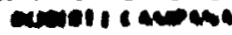

at and

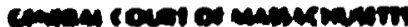

iremolve o ent

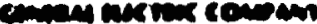

crise on of ment

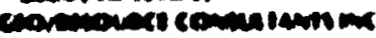
atime in a

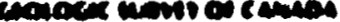

netiet ining

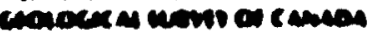
arrome in

Mme call

crancrese unots os ermanem

1 I andreven

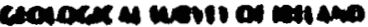

uncina be nas

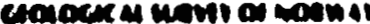

whelotion wos

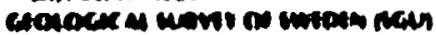

a cinciana cronctrone consutinc choup

I1 is 2114 1.,

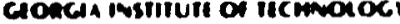

sillitil inlie

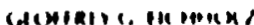

aligitu $x$ mithe

CHARIST WI AblR

ctorecuxara encmitas ux

RK Hatis a Revel 11

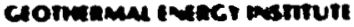

conato! Iist

cromenum moaso comars

comionial iso abitat who chint

Cromons

thas we vecte

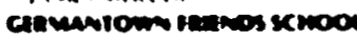

mRe eAsm

cranccing te stramen u

Unmationscmenc aren.

noxican, mxy

Mruablen:

navs IIt

"vena

intiven

crose min onc

nouste int is

encierconnoniman

wein' I thin

choosen mavingen on

nunter sal in

cortin arortutis

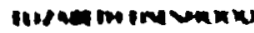

itument a notil

ron

mmap w al nes

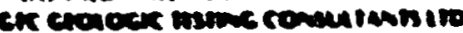
nent in at w

crut nivastate tre

rowomint on

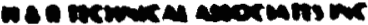

aritione mines

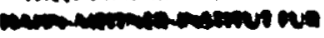

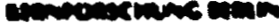

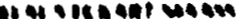

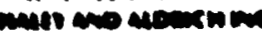

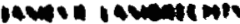

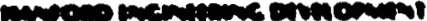

unesces

Heals en twits

conint omondit

a ine mi

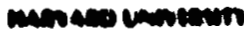

twatis on owaty

baces a mastist

cavining verten

conerescer

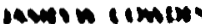

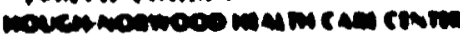

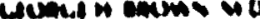

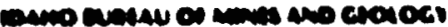

tall a newit

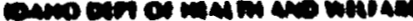

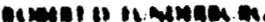

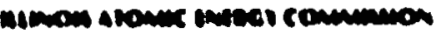

list I nutisw

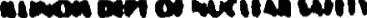

um nin on

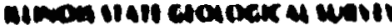

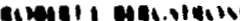

when thingn,ol?

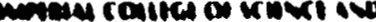

Hesimenges

- ataiven 
monana cectocex al uabl,

MAI RH I BNA.N

mogama chaviauls

I. imonil

Mavion W we at

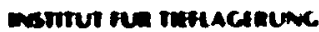

wiavi eatwily

Al al bal int

in wilin

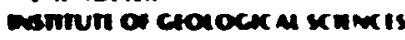

win a cramiat

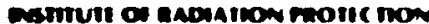

anithingust

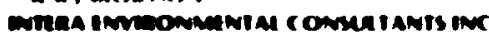

i inaris in

romat uniw

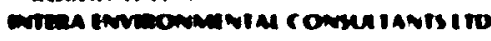
I (Ma)

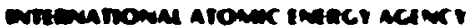

evintita reres

inava a conaka

entinanomer enticl associatts to artan itroy

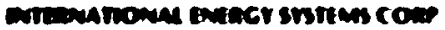
cown a comits

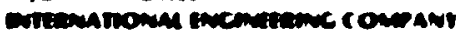
enc

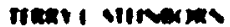

wat ray Anst

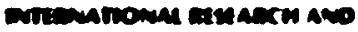

civereatron

a Davermi

cona crouerou nums

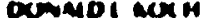

coma siant conmines conmminom

ecomar I encests

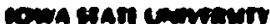

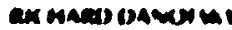

naerme itwives

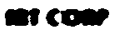

1 olcuss

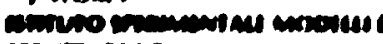

encher 14

$$
\text { - IALA }
$$

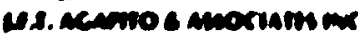
cex neyt Mares

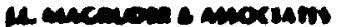

it unceriara

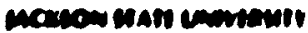

cotes umise

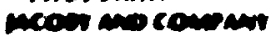

c naveres ias ent

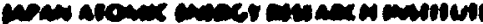
IAnO IMS

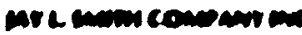
out avies

receonoming

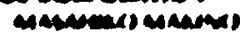

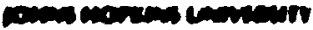

canor C crum

coneses at atie

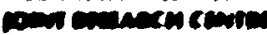

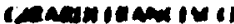

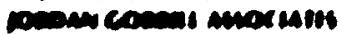

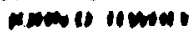

cemes cercones ind

n I innum

1 - mencen

cuameros raneres

enters in al

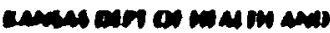

canconiming

canail in wils

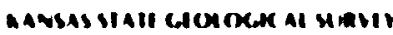

WIIINII ININIIIIS

aes

IARI UNCWIS

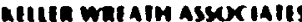

IRATh IIRI AII

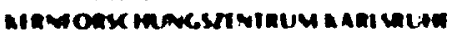
Gumer

a colem

inmol mvingent

twon aseociates

ilnter alies

nome answivit on tanct and

atsouncis entar

inivin an

aroto enmerest

ormiller inn I

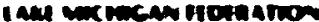

iny venactere

eare astia avien tomats

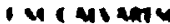

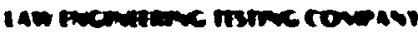

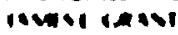

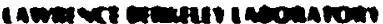

KNot in

IFw Natister

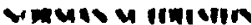

mat avines

- w wint

crome en tre

I 1 เง.

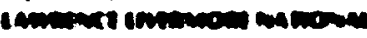

coriseres

intwe actom

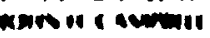

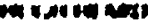

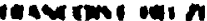

a is ventere

- and iotit

- averar costruse

par or merta

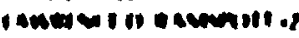

uester mant

* 6 N Te twis

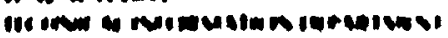
11

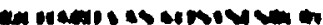

cound of nutal

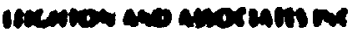

con en it ats

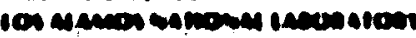

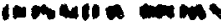

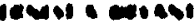

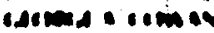

a comi

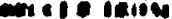

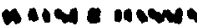

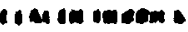

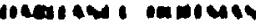

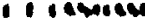

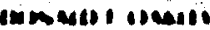

- Iniar

cinell onesio

arom 1 minalit

or et werisuer.

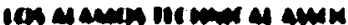

incos id to

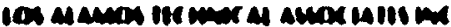

- I sons diva $a$

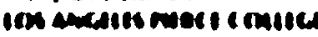

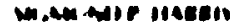

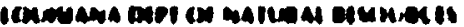

- manmill

Ieane vaminat

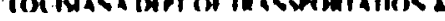
entionent

$1,1+1)_{1}, 1,1,1 \cdots$

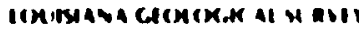

IIIR:A, 2.11

whinder

11 "1 11211.

louryata covienms Gik:

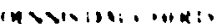

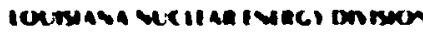

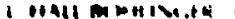

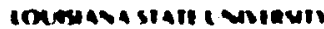

rimid. :onk.

counsata if netortents

ine int

invily II :

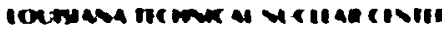
- "10mimi

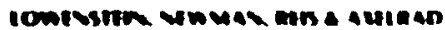

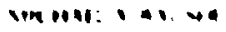

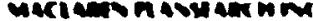

utomen.

ware chonoter as uenes

white inken

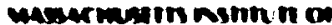

nemphos:

11.11

nen re. "...

nowertivind:

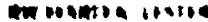

wamestiture

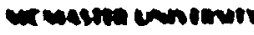

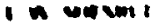

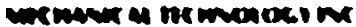

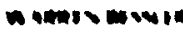

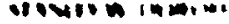

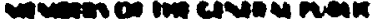

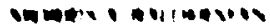

corrom in

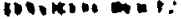

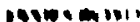

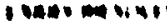

nullop! inon

ovent? "ont

nellow I Ins

mot in nient mi an

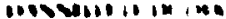

In 1001010

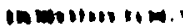

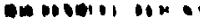

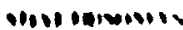

conetio bil.

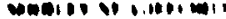

nowe o.1 (x)

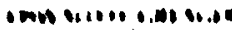

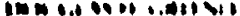

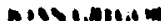

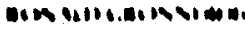

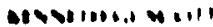

- I Mono

vesil onmils

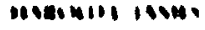

107111, 1061)

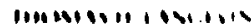

a. In + ine

1 1510 . Init

neera, in

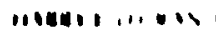

$11+111101$

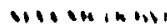

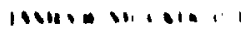

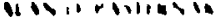

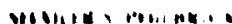


eox.tal mintes

MARITSRAIITA

IIRISRH 11

pil villum

a1)

41 VIIthi

andu! Wiel

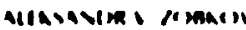

mocruace oavile, in onx

c I Ix+111!

mencay otri of mallenal atsorime is

a IIKMAN 46,4II

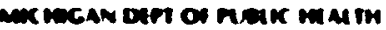

(X) DA I I ARCMI

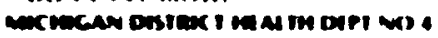
IIM.AR AnIII

ax encan clonocex an unve

minets atil)

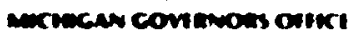

milliand tartem

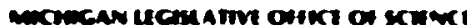

anver

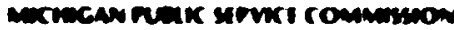

acnisilt

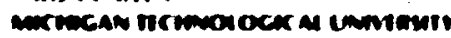
A.Aen' I in mot

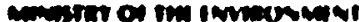

raAa v whI AW

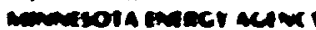

val vaterver

miniota crococer a unte

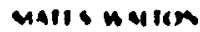

mmocia siat timect acenct

coste en wita

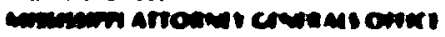

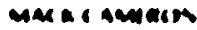

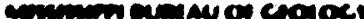

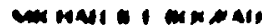

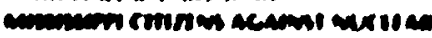

encom

Haver in the llist

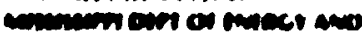

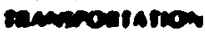

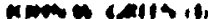

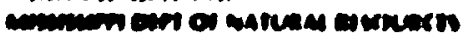

astate ande in

c naviose cures.

ceninon virne

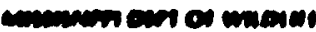

somitevanes

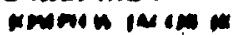

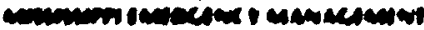

Acenct

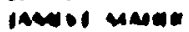

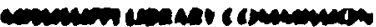

ona lie

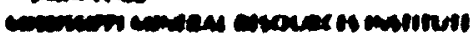

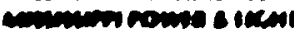

animet warmin:

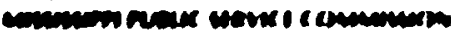

- Nollos on mis!

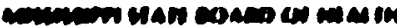

114me 11 cases

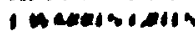

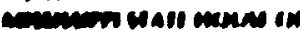

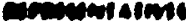

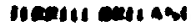

- concisia monas

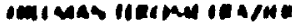

nest initil

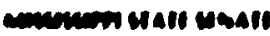

watelin I sellit

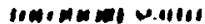

Mitni come

IINIT + IIIIING

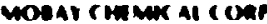

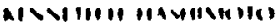

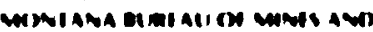

chexoct

I I,Rin!

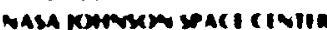

Min IIAll e laillal

alloman ac abint on seners

rats I inatim at

milen wites

Gatconar areonatutics and sac

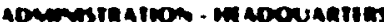

new or a cosetion

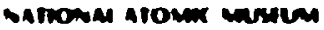

I.MIV W intive

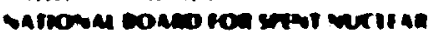

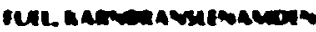

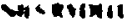

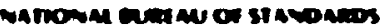

ifuxin (ADAtivat

awiont altis

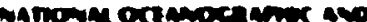

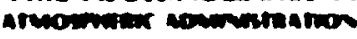

IM 4 in ind

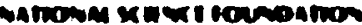
mon I Tritum in

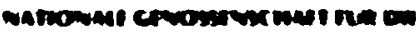

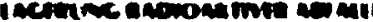
Marmustat on

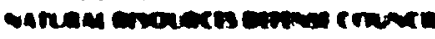

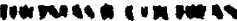

meaca cim os rings

arimet it in

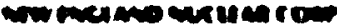

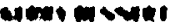

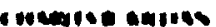

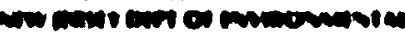

Minition

ancist in.

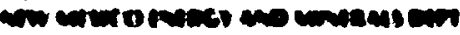

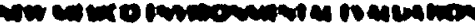

con

crimes in vin:

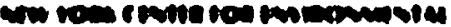

momaring

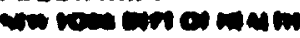

ostes owreantents

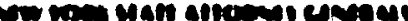

crint 1

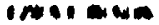

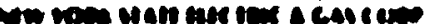
itcines valt

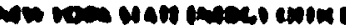

torts weine it

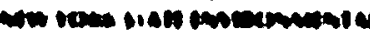

curevine cones

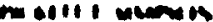

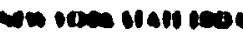

mersi in ones.

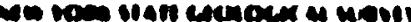

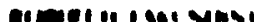

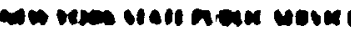

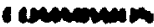

1041: ind 4 .

nw vere tantewts mom a cerle curet ilu wen 11

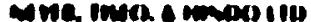

a or inver

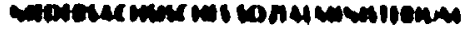

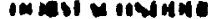

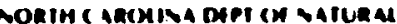

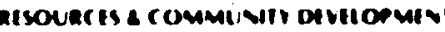

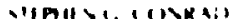

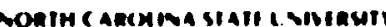

ve animimit?

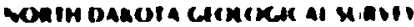

Ixis: 11911110.10

comin banotasiall I Wianis

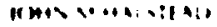

colmast bua counte atcronal

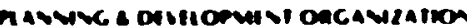

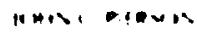

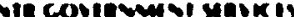

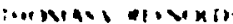

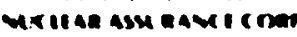

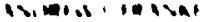

nomb in wink

coment inte.

listron nisolle

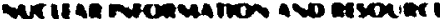

vater

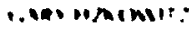

aritan serth sucriats ne

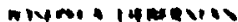

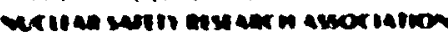

- vis un wivi"in

ceree wast warmen

ininitine

wertion

n., *

nensw 11010

- mimol invi vol

overevo Dier

tan

innidion temn os

anteres

A. 140

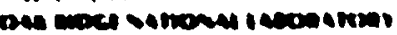

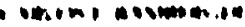

10 Bome

ou 11 van mo

niov. in

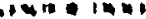

and iviny de

- cooven ona

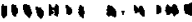

- ming

110011 inith

1. I1 11 va

trones ving

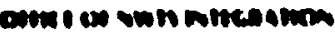

ondest initivits

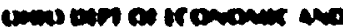

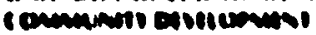

Hithe nuthis

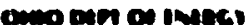

I niln aix nuld

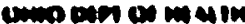

cimed is th thits

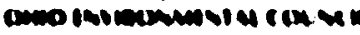

Minat " 11110

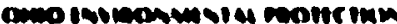

acond

nome wi in comets

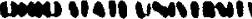

- icmisit by

1 1 coshise

I1 1102611

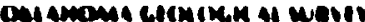

insill "its ?

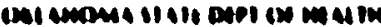

4.11.

\section{$80048 \quad 1104$}




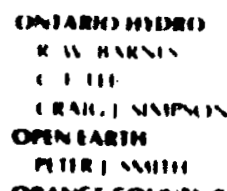

omance conatr rommenals comile I Ankixil ingil

catcon orm on inates

IMNAIII IS IAIARI.

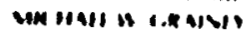

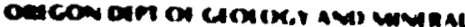
mocestums

oncom stant unmeste

existixux)

I I mivat

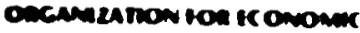

cochination and orvetomane

i. connir

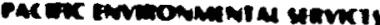

extat al !

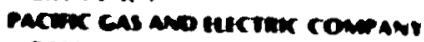

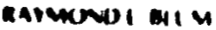

and at 0 valti in

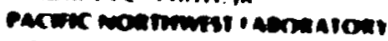

ixni catinis

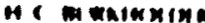

I I ciaka

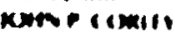

maxvotixat

combill in:

I is inkett?

Meto ancitin

(x) Nati! IAkn

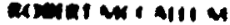

anitan wiver

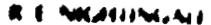

in ations

a min 4 an

1 ( naturn

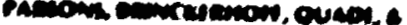

coveras me

1 ainul

exemence

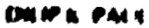

and olline

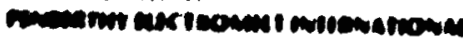

m.s.

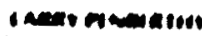

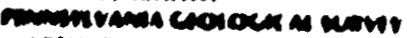

ninin a warem

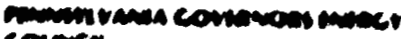

counis:

menci gacions

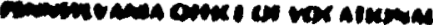

rancination

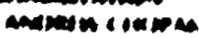

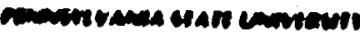

nuscian an oure

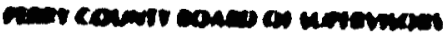

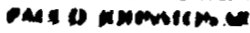

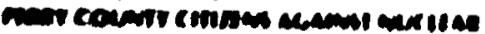

veria conom

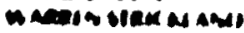

reva raster.

rent cepert vemens

manese a carienas

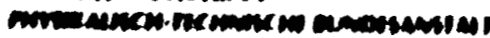

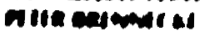

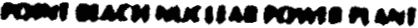

calora a Atils

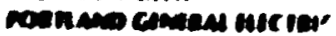

in Ilvive it

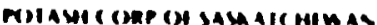

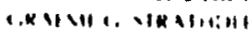

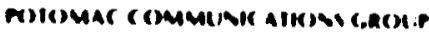

Hits It HePk

Rumin alimoriti on int stall 0 win roan

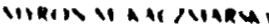

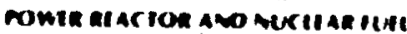

onvilomani comonation

mequa mi c ovatimous

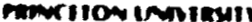

nile im Nind

1. I muth

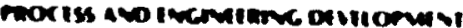

idesitil mitit:

Gen iaw utuires coove

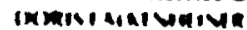

reck struce mpave

nomers nictu.

nurot constasit?

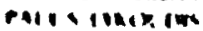

cuncese cone

InAmki al vun

a encomacisares onc

trimel trim

anomancons

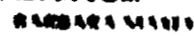

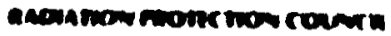

Jint imerus

mine nat

part 1 comen

chreace crito

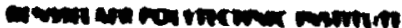
incurat

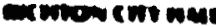

- MEN4

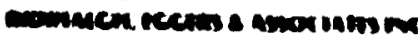
naner risine

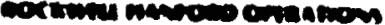

minatse iresis

oranet savers

1. oserve

- ine

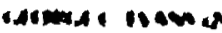

1. inten

- 1 comer

or verogent

- anis uner

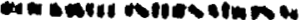

- cimar en a a

coses a of towe

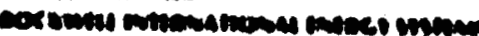
core

n. inatis

nowo on anises

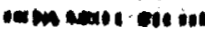

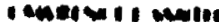

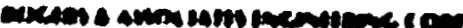

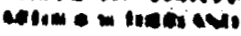

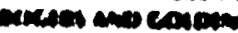

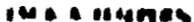

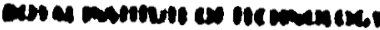

in con and lates

ancing

areat ecm!

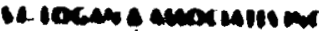

thanti 1 irim, th

c.u stanes cos

aiviel th at 6

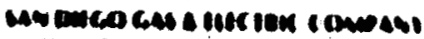

cin neveralis

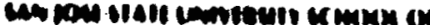
concrimasings

- oninemor

80040
Seve Ata ist

Q $1, \ldots$

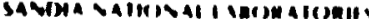

1.' '.

$\cdots+1+1, \ldots \ldots$

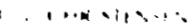

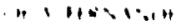

- . $\because 1, \cdot 14$

$1 \cdots, \ldots \ldots, \ldots$

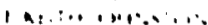

ine?

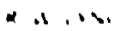

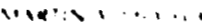

Mremp. . .

ane? ve

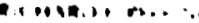

, 12 ans

"1):

"W Mrime

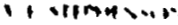

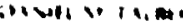

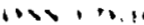

nit? and in

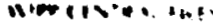

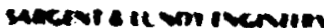

inderwi 1....

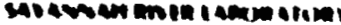

11 indw...

- Inxintas

tming. Nont

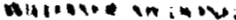

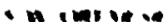

inn wisine.

11 140

strace enn arrones ne

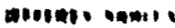

cher. Pent

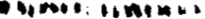

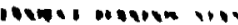

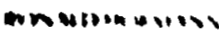

in is a. 1

briment. Malocion

benowe iselise

nite! unisetio

wen! in mere

on monit met?

anmout $n$ oce.

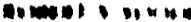

on ming vin

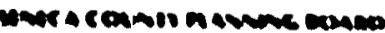

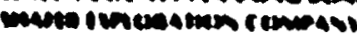

nnilaw: woun

mencos a wiven the

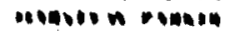

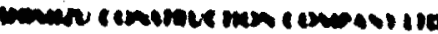

in ima iven.

cmencese

ini in obis

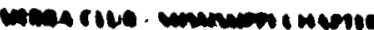

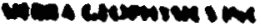

qenot,

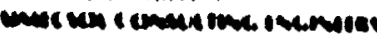

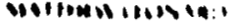

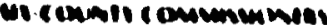

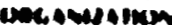

1. "1110 - 111111

Wat ente ullati

lis in th:

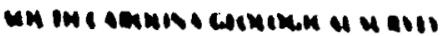

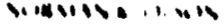

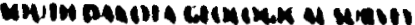

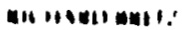

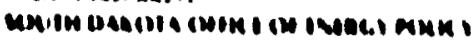

llits $11.11 \mathrm{l}$

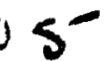




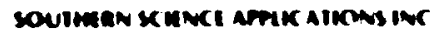
a II ARBS

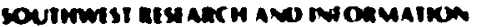
ctwren

ix) Nincina

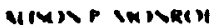

st comavintuat uverents

I Aki I in ARin.

st rosim contes

ciart Mankitive

s) mantin ncen scmoor

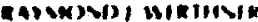

Samom Unminstr

nona nis a nal W(m)

nuiv ainus

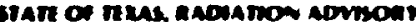

conso

ineanilsir

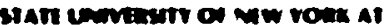

comenamton

IRAM 10 W1

stramenocen eremers bux

bitio ix bus

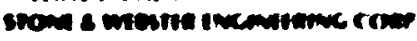

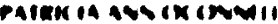

inta

4 nimi

istitis naver

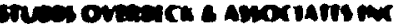

ten: arn marm

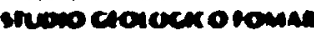

a Mantismata

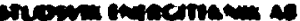

and merent?

ant wonsen

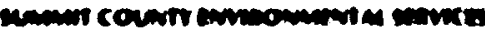

Iavers I curr.

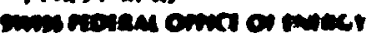

1) ructeren

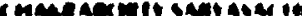

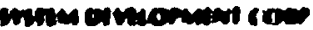

nur walds EN OAM

of 4. DAMt

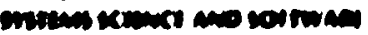

rive inas

tacentester

vorete calle

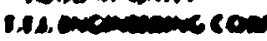

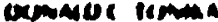

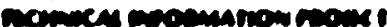
ermancenar

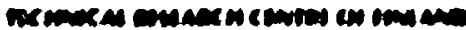

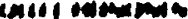

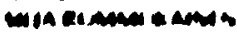

acencengy

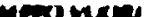

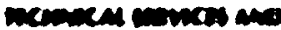

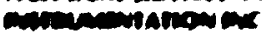

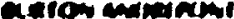

arem

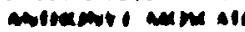

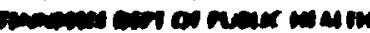

mi canian

waceses

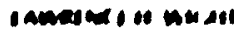

nom and

cruavibimal

renemerives ent

remacte ouras

reses acen enmacost

num нemina

an in wara in

cists amerema cater Romats

IASII 11 ?

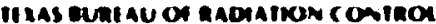
(x)SAII), Avinewis

Irias oret on math

lialli a I Ac aIR

IIAS tMaGr vatuan misovaces

abviont counca

Iteren nercis

IIIOS! innicmals

- vercen aiv.

ecratel o villot

neas cent mo

1) ic $x$ w.

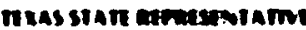

AII 14V?

m and vTK schincts co.

nen $n$ sanutill

conaris wionm

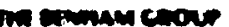

as 4xin:

on thingers

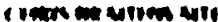

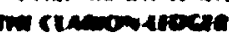

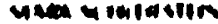

thoritu aroconths

i tiniven

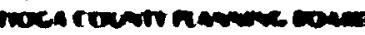

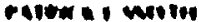

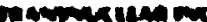

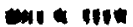

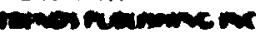

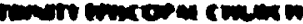

menaver this

tiring

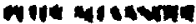

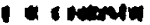

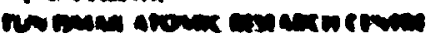

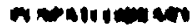

nowina coumen

incm trovesere

YNDO

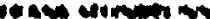

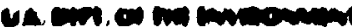

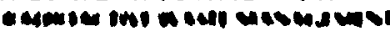
anworts

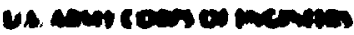

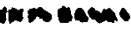

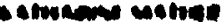

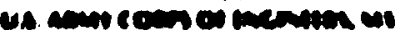

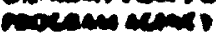

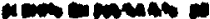

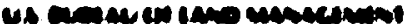

ing ine in

cinet wive

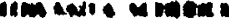

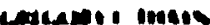

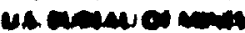

cermet antermme

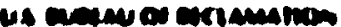

cind it an se

us enor canmers

wite a niche

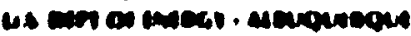

amesnoms arent

- ismier

manc un ed the

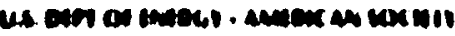

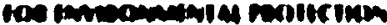

- conmesilis

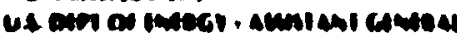

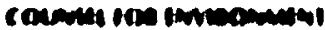

il catinimal

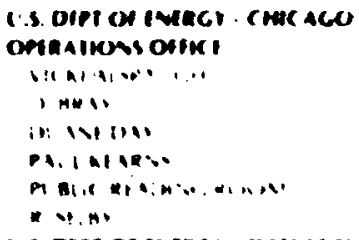
otens

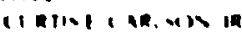

Us otet on twext - Onbon on naste mesirom ornotwer

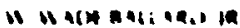

in movit

- coman:

to sents inter

ving ones

cotrotidinte

cier valimivan.

romeniose icmes

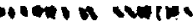

Alt cumato

eume inis

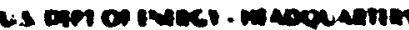

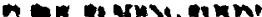

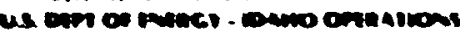
cine

Noventy

inese lion via

che cermeron

nna matowimn

in 1 stat

mone numpti

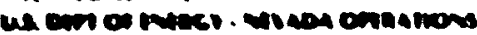
entive

1 intin

wo in wh

non ar awn. in an

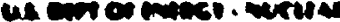

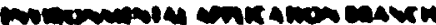

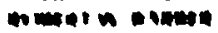

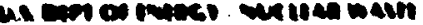

osm ans woll w

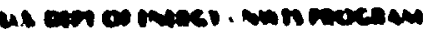
covite

isonimit

4 ow wate

14 190.

the peat t imit!

- innin

1 milar

in will

- in

- I ni ungan.

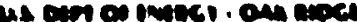

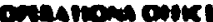

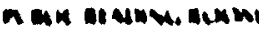

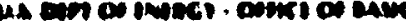

thenge cring

wate $n$ nillil.

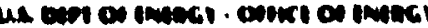

sticerm

10 end I niment

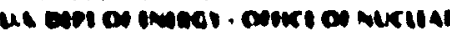
mencers

a c ciatul.

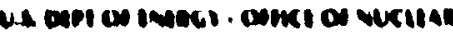

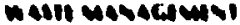

Itentidis

in nimuin 


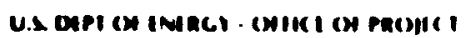
AND BAC GIIILS MANAGIMLND

I) I HAKllit?

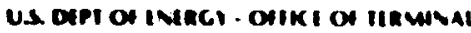
WASTE oEsosa

IRAThIIS ( 1 HI III)

us bet on intacit - Oriki in nasll moxarion

KMPI I I IKI

livil Wiallis

us orm of integr - oitri on wasil movucts

Ca Grill

IAwes II tel

US ofer of inenci - atcion vim

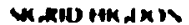

us oin os thenct - aximavo

conantions orsec

a casanos

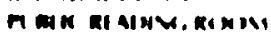

1 c iexione

1) w wats

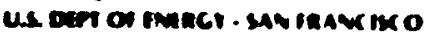

Ominamons orexte

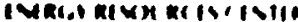

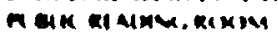

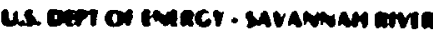

cranations ortkt

aicdval Ilakkis

1 intarist

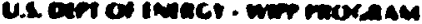

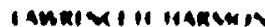

us cret o tanom

atic 4 insti

veresta nI

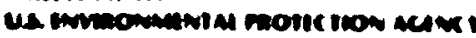

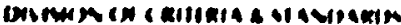

cxinallion tilk

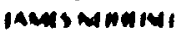

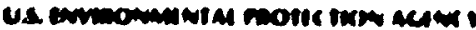

- encrona

Kre 1 tilants

UR crumer ac countonce onere

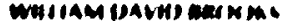

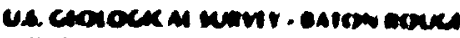

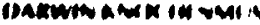

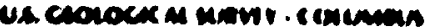
a M I A SAM A IN

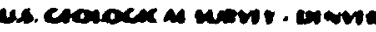

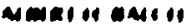

M D minarite

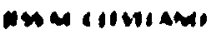

Le tom

menares ing

ar cortente

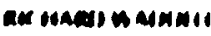

miscian un un

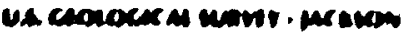

Ganwios, paimin

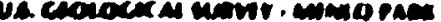

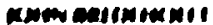

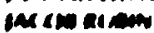

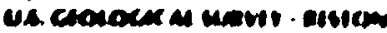

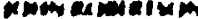

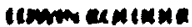

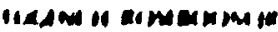

nise a bilnos

cosmbe Honall

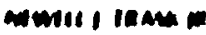

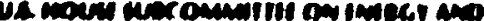

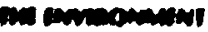

carmens a (AI)

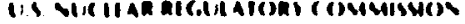

, III. HI, 111

a monit

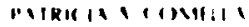

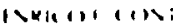

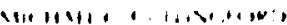

11391,

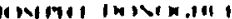

I I ixivil

I RIITRIS A IIMUTIHR

RIC IISIOI IeNIl:

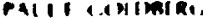

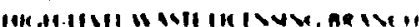

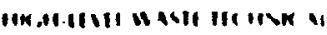

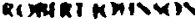

civin milie

monis: in vil.

intient al inW.

14 IIIIter

1001 1towi

ine ine

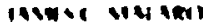

nerot nentis.

kwitr Whis

19 the Wh wile

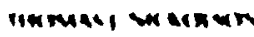

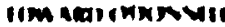

a wor of terve

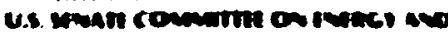

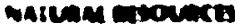

nuin is willo

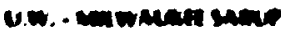

ADV a thi

unst comm

imitiata

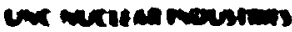

IItranitet

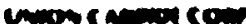

awas is watewat

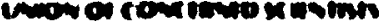

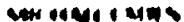

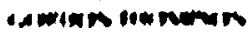

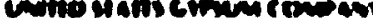

1 - cum mint

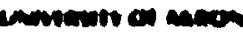

- o. octiminti

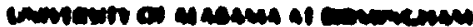

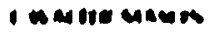

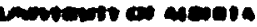

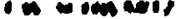

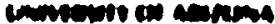

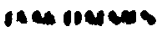

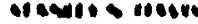

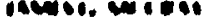

wermore wi use

nove, nat

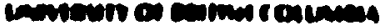

- un al reter

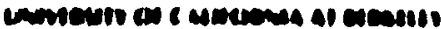

nomit t. 1 inc

inmoriancis

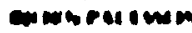

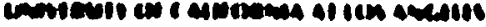

11 a mat

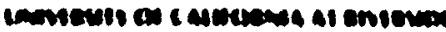

tinmeteres

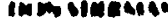

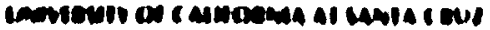
Mini roisums

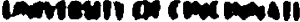

ilin $\operatorname{con}$ in

menteits on ats in

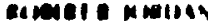

ieant a i in at t

11. 1 .

1, 1, , , , , ,

vibrell (n man all at Mast)

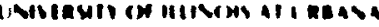

(HAWAKS

11)

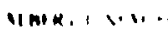

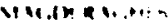

mistasil on innill

1111 -..45.

Uabersis on Matiant

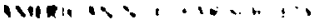

Menis

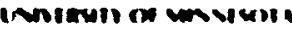

11. MP:

uncersin on versum

eime! i ip

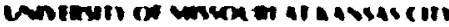

hinits 1,104

ment $\cdots \cdots+12$

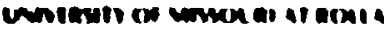

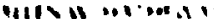

enturia ving

in a inx in.

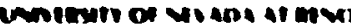

rume, in:e.

minsmiste

uncinin on whe

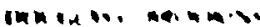

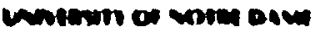

nen11:

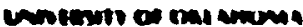

bovat i mivinneor

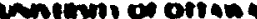

1. Vou omity

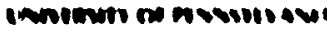

tovistento

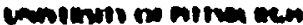

C 1 1 ions

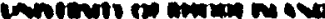

itum itior I ty

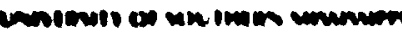

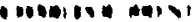

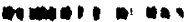

cestioner. in mit.

liven an mon

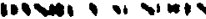

tonot nuimits

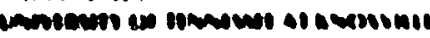
10 "1 vel1

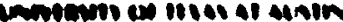

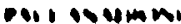

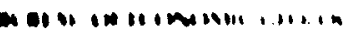

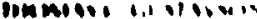

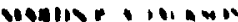

livilestis

ต I IIIme III"

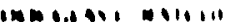

1. Mieven M1

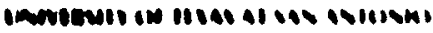

in w 1111 il in,

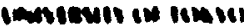

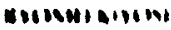

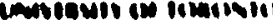

- Hinn.

uncritants an vish

t. In! 11 int in

vinndention

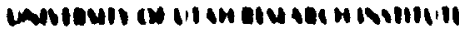

in th is hil

inem initer men

$80040 \quad 1107$ 


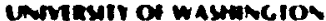

(I) III GXXA)

a 110111

11 torands

unmerst of mestian onianko

mullews 111

cmmentr os misconst

- inalses

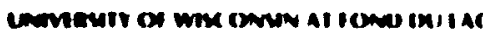
MMIV IN II

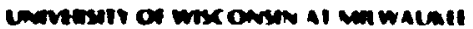
Hom aks nak !

Unstom a nuare a assoriatis. tercmetss

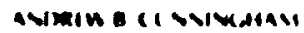

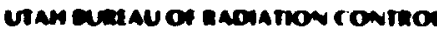

isknill on uAmuts

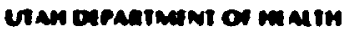

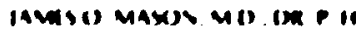

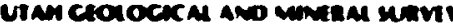

Cantan amexis

nace rondiat

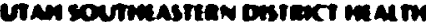

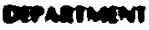

rovatit Heatim

crans siane unments

tomet in CACxix.

comitr pata insteterts

Imis toni

ranbiamt comvist

renava i palente

ningo

or von.

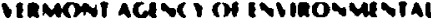

consenvalion

(114kII) Q alll

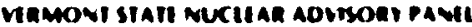

Irocivia ( all Ay

bincena dept of matim

ROAHRI C. WKAIISI

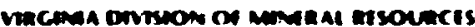

ermali binn

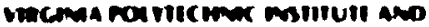

seate Unmasts

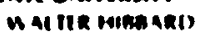

Datue nows

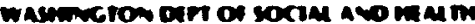

semkes

1 stection.

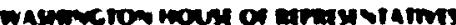

M MAM un

wasmincrov stan unviast

cacmeda il at

watma

cone natr

wame gati unmidn

javis t wers ate

menery

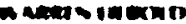

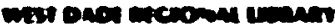

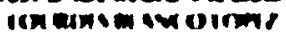

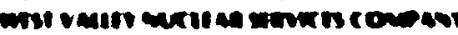

ins

ix wath 4 nover

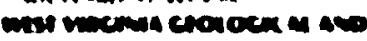

comenct wam

crinet iren. meslinchouse itlc ink conp

i ARCM A A.8:

i) VWW

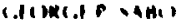

$14111,+1,91131$.

nisirnchouse whe nower

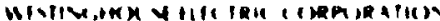
mic onsin orpt of loc al artans and otritoment

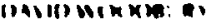

meconim ontron or slath rence

ausert in tiviling

mixonin ceolocr al ano tatuan

ustont sumets

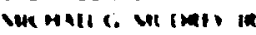

chereatel mineme

wisconim wux sence cous

pil nivnia

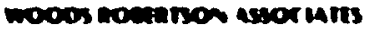

moom andective comsentath

- conatil:

uen in parn netmons

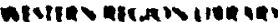

minnter an

nall Thation

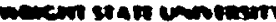

- int

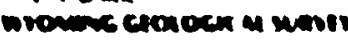

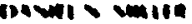

cen chering

an anvin 


$$
y
$$


:

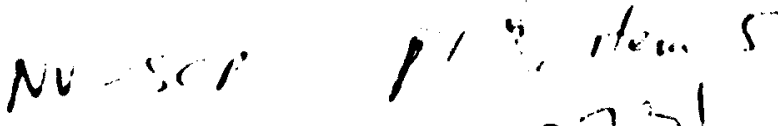

$$
\begin{aligned}
& 17-3731 \text { His. } 380517.8731
\end{aligned}
$$

BMI/ONWI - -354

TIM 009083

Archaeological Data as a Basis for Repository Marker Design

Technical Repent

Acedias iss

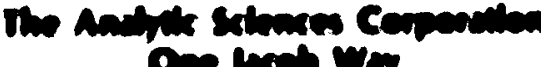

Om ned wo y

MASTER

DISTRIBUTION OF THIS DOCUMENT IS UNLIMITED

S

ONWI

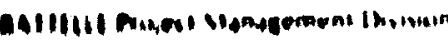

180040

101 


\section{meIIOGRAPHIC DAIA}

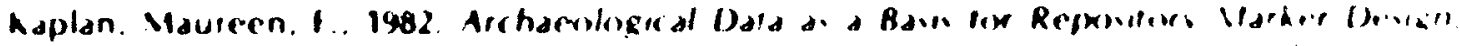

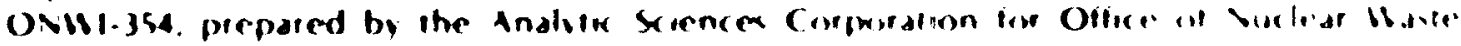

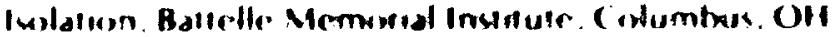

\section{notret}

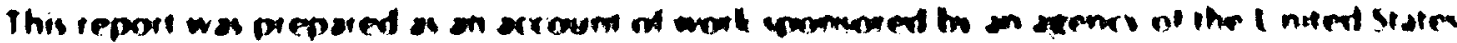

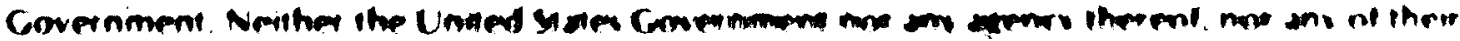

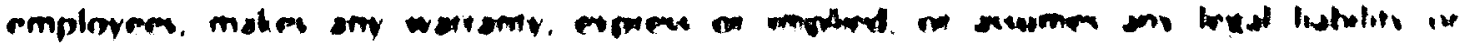

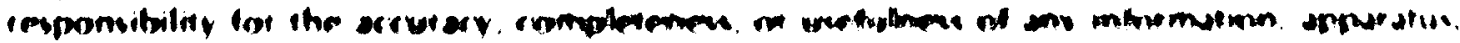

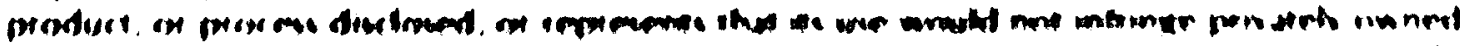

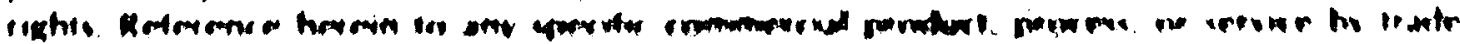

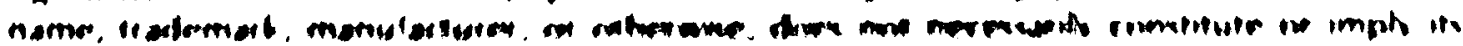

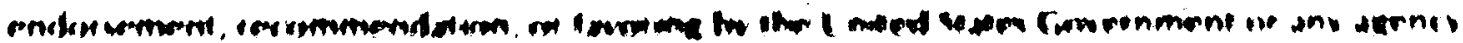

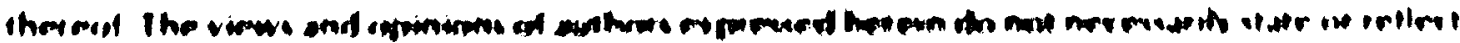

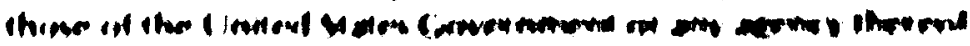

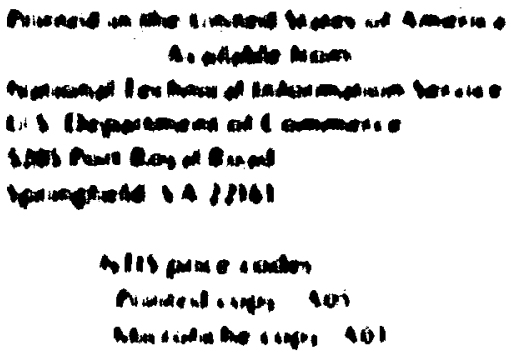

$800 \div 8$ 
ONWI-354

Distribution Category UC-70

\title{
Archaeological Data as a Basis for Repository Marker Design
}

\author{
Tectunical Report
}

Ortober 192

Menimen 1. Then

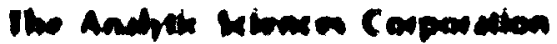 \\ Orme ruab wor

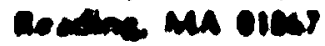

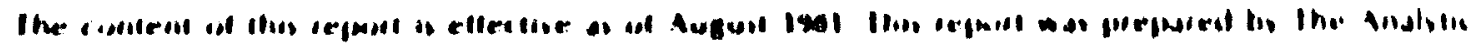

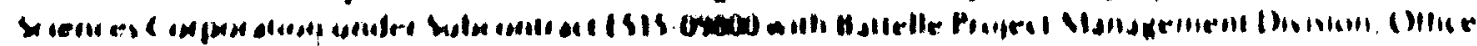

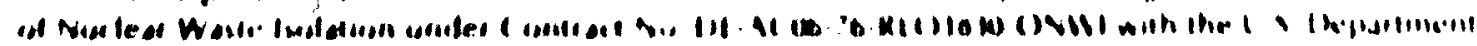

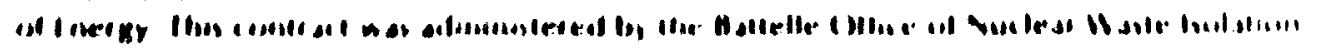

$$
800181017
$$


ABSTRACT

This report concerns the developoent of a arking systed for a nuclear waste repostcory which is very likely insurvive for in, non years. In order to provide a backpround on the subject, and for the prellalinary design presented in this report, a discusston is presented about the issues involved in human interfetence with the repository systew and the cowmunication of Inforation. A separate chapter sumarizes six anclent wandede moments Includ1ng: matertals, effects of assoclated textuli information on our underatanding of the womuent. And other features of the ancient wonument relevant to arking a repository site. The infurmation presented in the two chapters 18 wed to provide the basts and rationale for prellatacy arker systen design presented In fimal chopter. 


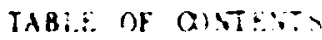

Page

I INTRODLCTION . . . . . . . . . . . . . . . . . . .

2 HLMAN INTfRFERECE . . . . . . . . . . . . . . . . . . . . 3

2.1 MESSAGE EXISTENCE . . . . . . . . . . . . . . . . . . .

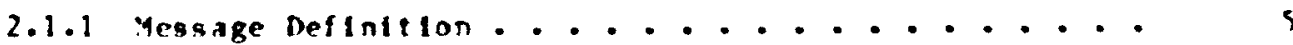

2.1 .2 Mesarge location ..................... . . . . . . .

2.1.3 Megage Sutrivahilizy . . . . . . . . . . . . . . .

2.2 MESSACE DFTECTABLLTTY .................... 10

2.3 MESSACE COMPREhENSIBILITY . . . . . . . . . . . . . . 12

2.4 simmar . . . . . . . . . . . . . . . . . . . . . 1 .

3 ARCHAFOIOM,ISA. MARKERS . . . . . . . . . . . . . . . . 19

3.1 sflected Examples . . . . . . . . . . . . . . . . . . 10

3.1 .1 pytataq, tegyt ..................... :1

3.1 .2 stomehenge. thelant ................... is

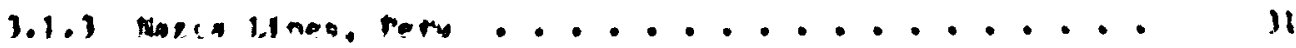

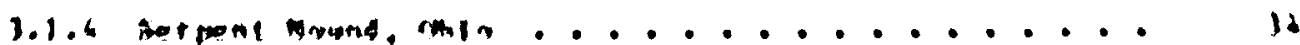

1.1.; Aremglit. ctoare.................... in

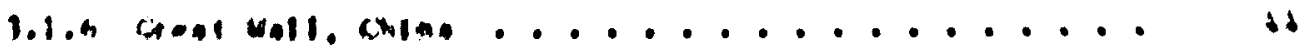

1.2 ntachistion ............................ ... 4A

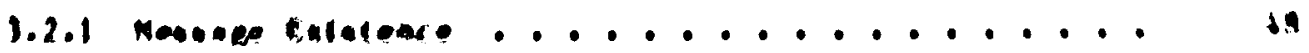

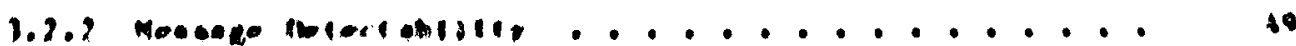

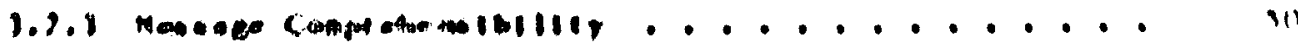

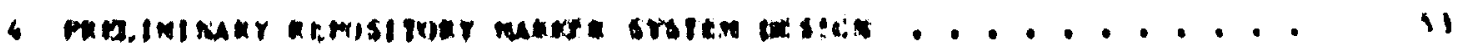

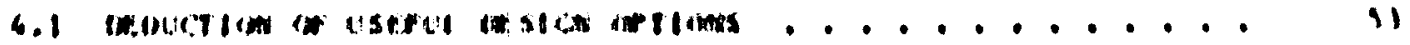

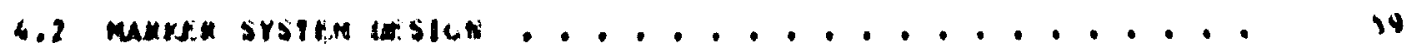

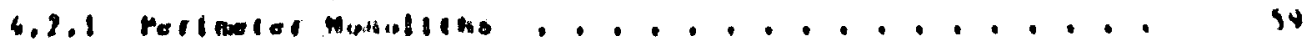

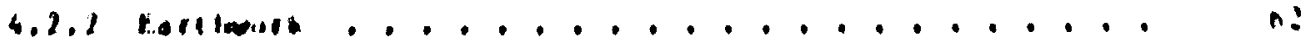

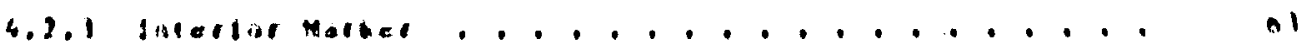

$800.10 \quad 1019$ 
2

$\because$

TARIF, OF CASTEATS

(Cont lined)

Page

4.3 MARKER MESSAGE

ni

4.3.1 Perlmeter Monoliths.................. n

4.3.2 Fartmork ..................... iz

4.3.3 Interior Marker .................... ;

4.3 .6 vault ....................... ;

s summar ................................ ... is

KEFRENCS .............................. i

800 i8

1020 
$\because$ :

B.IST OF Flalkes

Page

2-1 Maln loglc Dlagraw for Warning Messages . . . . . . . .

2.1-1 Logle Dlagram for Mesage fexlstence. . . . . . . . . •

2.2-1 Loglc Dlagram for Megsage detectabllity . . . . . . .

2.3-1 Logle Chart for Message Comprehensibllits . . . . . . •

2.3-2 Example Symbols Used With Atoric Materials . . . . . .

2.3-3 Scene Frow Towb of DJehutyhetep Transportine

Stative to shrine ..................... Is

3.1-1

ryraulds, Egypt

3.1-2

Inner circles of Stonehenge. England

$3.1-3$

Plan of Stonethenge, England

$3.1-4$

Serpent Mound .

3.1-5

The Arropnll", Greere

3.1-6

$3.1-7$

Plan of the Acropolls. Greece.

3.1-B

The Gireat wall of china

$6.1-1$

A seguent of the cieat unll

$4.2-1$

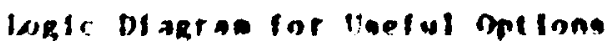

$4.2-2$

Perlater Monolith

$4 \cdot 2-3$

Pabunkont and blech conotewtion (section)

section and ing view at lumplue and inteplor

Monolitho. . . . . . . . . . . . . . . . . .

$4.2-4$

Inferlor Monalieh.

$4.3-1$

periecter Meonestitis

$6.3-2$

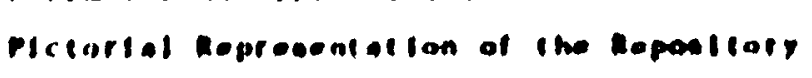

$4.3-3$

Ineariar Munalith. . . . . . . . . . . . . . . .

I.tit of inatiti

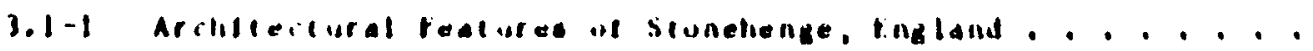

:?

$80010 \quad 1021$ 
The Office of Nuclear haste Isolation (ONWI) has established the Human Interference Task Force (HITF) to respond to the issues of huban Interference activities in nuclear waste isolation. The purpose of the HITf is to develop an approach to reducing the likelihood of future husan interference with the nuclear waste reposttory systea. The HITf has focused on the developent of effective, lorg-tero comunication systeas as belng iaportant for ainiolzing the likehood of human interference. Thus, the HITF is concerned with commutcating information about niclear waste reposicory locations, contents. and assoctated $r i s k s$, both at the repostcory site tiself and at numerous places away fros the site. The tive irawe of interest for the arking systew Is In,000 years after repository closure; chis is consistent with drafe cpa wasce nansgevent criteria.(1)

This report is writcen in support of, and is consistent with, the wrk of the HITP. It primarlly addreases the probles of aurking the reposltory ste by designing, watker systee based on atudy of anclent an-mode annuents. some of thich have ourvived for up to 5.000 years. The marker systen destin entalls both the physical arting of the alte amd the comontcation of Inforation abut the atte by the artera. In ofder to dellmeate the ceneral pre-

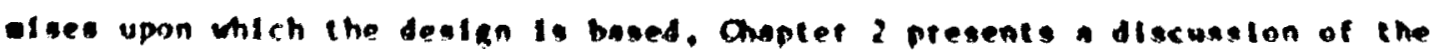

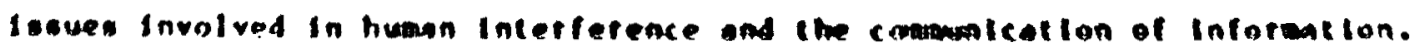

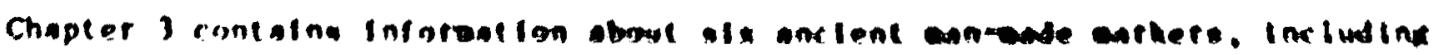

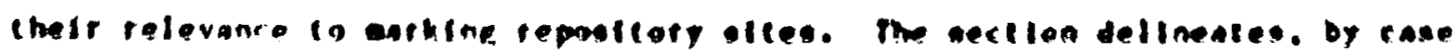

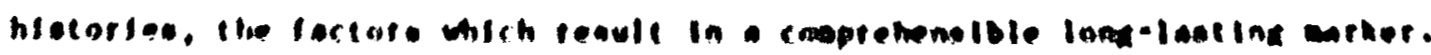

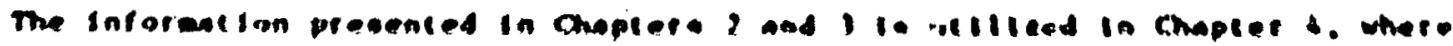

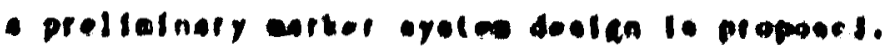


2 MLYA INTERFERTEP

The sate disposal of high-level radloactive waste. Is a subject of much interest (1) the general publtc and the sctentific communtey. One: method of disposal calls for the waste to be hurled la a deep oined repository with a serles of barrlers between the waste and the environment. These barrlers include, bat are not linted to, transformation of the vaste into a longlasting material. enclosure of this cotertal ia a durable cuntalner, fillity the repostinry with a material which reduces the access of ground water and retatds the transport of radionuclides. Finding a sultable rock type for the repesitory, and locating the disposal site in a remote area. Wuch effort has been expended to develop thesc harriers between the wate and the envirunment. Hum interference could perturb this systen of barrlers and reduce tcs effectiveness. For example. the systen could be breached by intercepting the waste through winling or drtlling. Or. Inadvertent intrusion inte the ripsitury system could become a possiblity in the future if records are lnst, ir mewury of site locations and contents becomea hazy. Thus lt appears Impoteane chat nuclear wante repostiory alteg be arked, and that these ankers survive for an extended period of time. The perind of interest used in this study (II).Min) years) is based on diaft riph waste manakement criterla (In crk 191$)(1)$. The lopic and diacuaglons wirh inline vere defived frow prelialinary mipk of inr

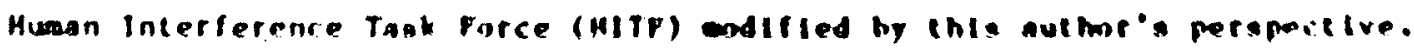
However, thoge modifiratinng ate congetent vith the nverall lotir used by the HITr.

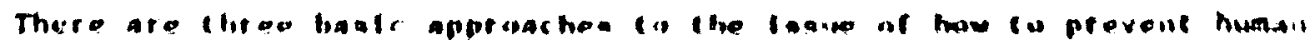

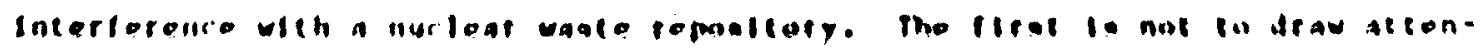

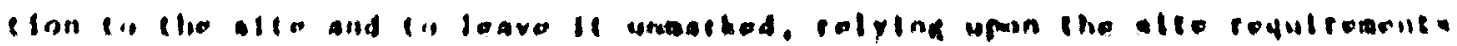

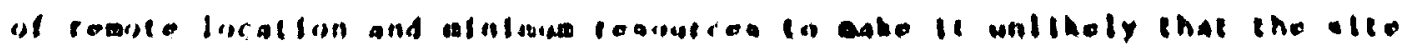

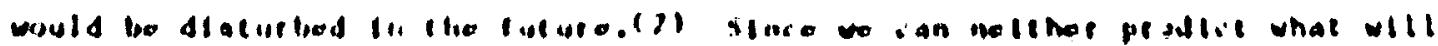

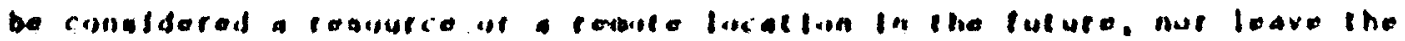

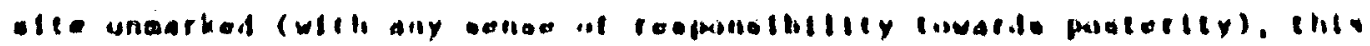
appruacli is mot cullable.

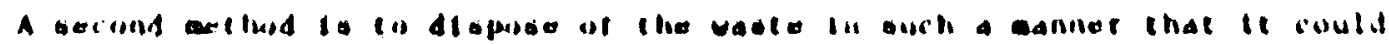

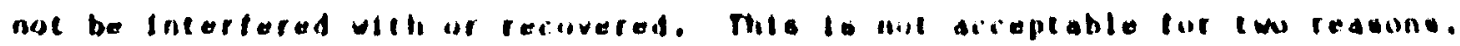

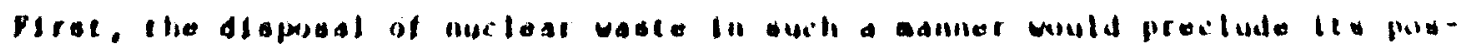

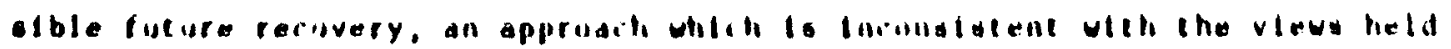

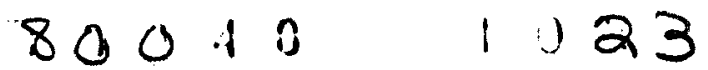


by the ElA. (1,3) second, it is unlikely that one disposil optioll, a repository system with disposal in a deep nine, could be desined which conld not be breached by cechalques developed by future technologlsts.(3)

The thitd and final approich is to rutk the ste and atcenpt la coat... Information about the repository location, contents, and assoctated rlsks t: future generations. This section discusses the general ingle follow.. is

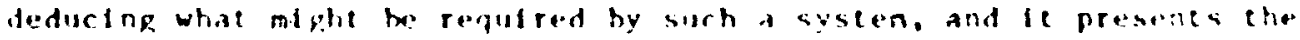
underlylng reasontug, whl h was inllowed when destgning the syster presented in Chapter 4. An analytlcal framework for ascertalnigg the means by which this information can be conveyed is given in Fifure $2-1$. The first ehree poines to consider are that the message must exist, be detected, and be understiod in order to be effective. Each of these points is further discussed in separate sect $10 \mathrm{~ns}$.

It should be noted that the objective of this rork is to have the nessate understood. The Department of Energy has taken the mosltion that this cenertIon bears no responibllity If a later ceneraiton decldes to do sumeching wich would affect the repostenty behavior fe.e.. retrleve the vasel if that generation ia fully cogntzant of the hagatde ard comaguences of that action. (3)

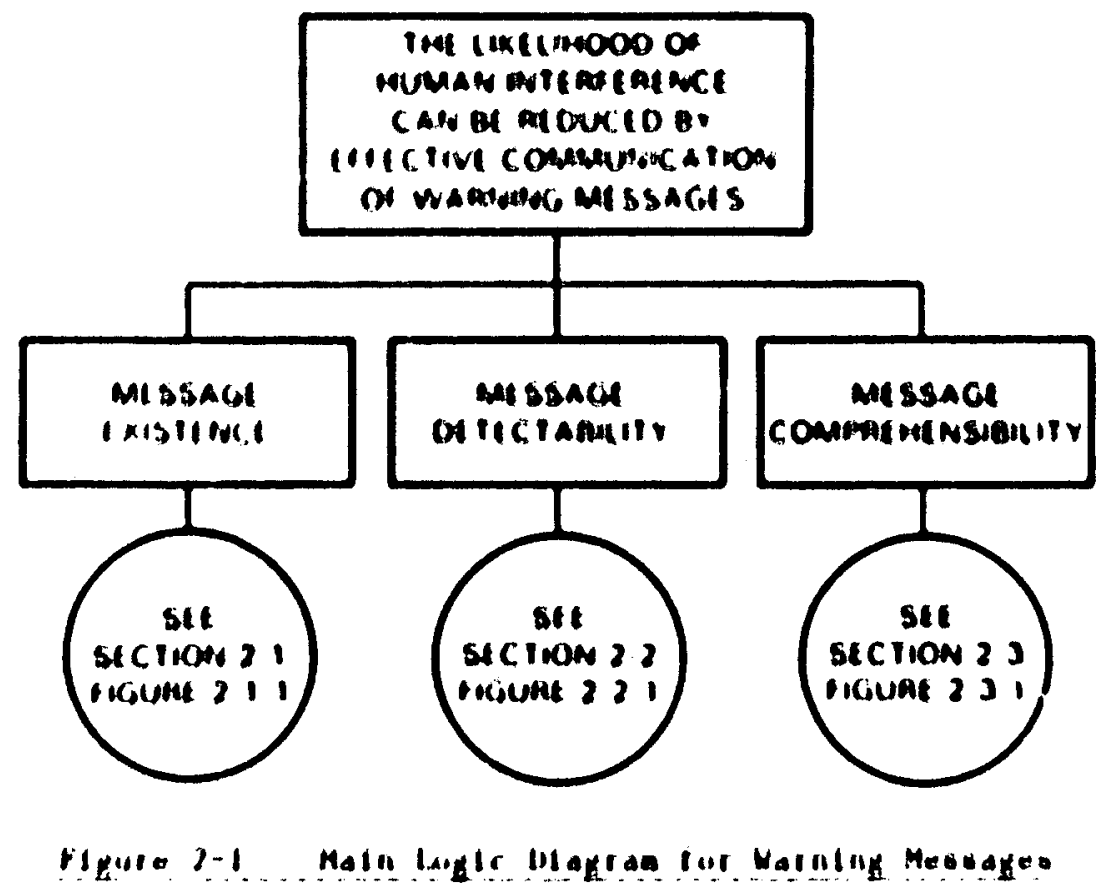




\subsection{MFSSACE FEISTHACF}

The dectsion to mirk the repostory sto mons that th has been destjed that a message to future benerations should extst. The next level of dectslua (c... Figure 2.1-1) Involves what should exist (gessine definteton), where te should exist (message Incation), and how long lt should exist (nescine survivability). Fach of chese factors is discussed below in separtie sections.

\subsubsection{Message Defintion}

In order that a message way bonveyed to tuture generations, we mist first define whit that message is and the audience to whon te is adiessej. Although this report speaks of a message". I.e.. In the singular. chere may actually be several posstble levela of Informition which can be convered. For example, the message can be ciastfied into four levels: (t)

- level 1: Attention-getter, 1.e.. smmething le here.

- Level 11: Attention-getter and uraing, l.e.. sumething ls here and it is dangerous.

- Level 111: Baglc Information, 1.e.. what, who, when, why, whas actiong in arola, and where to lind information.

- Level IV: Full record of Information. I.e. plana, drawinge. envitoment al lopact el tetmenta. etc.

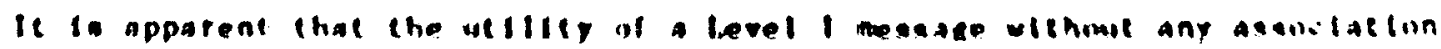

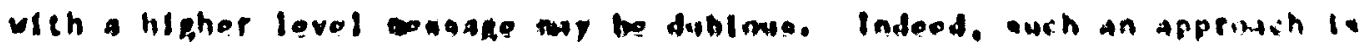

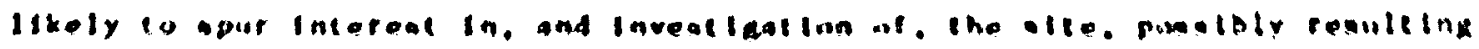

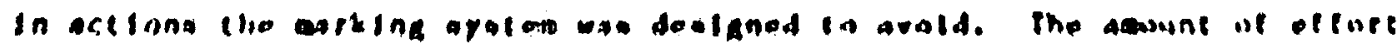

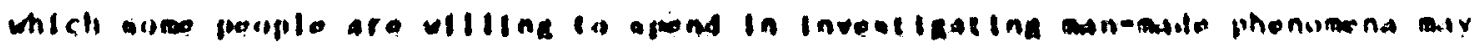

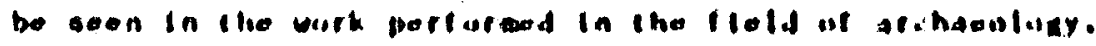

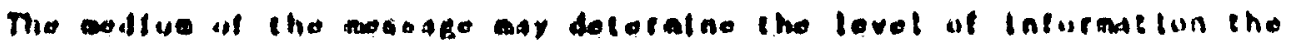

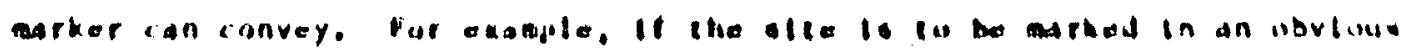

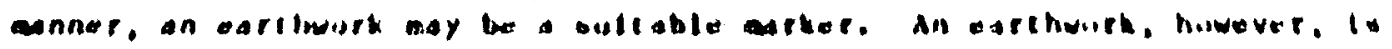

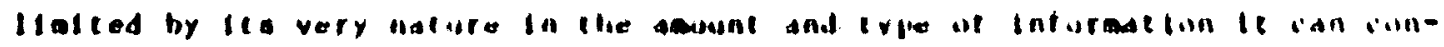

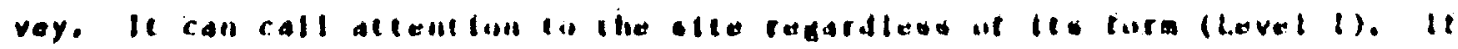

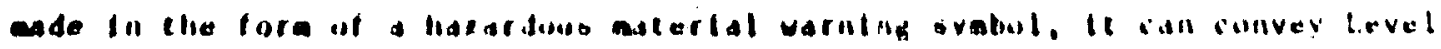

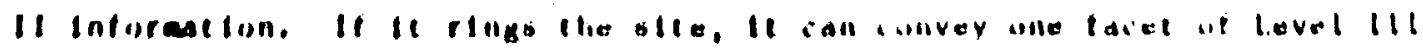

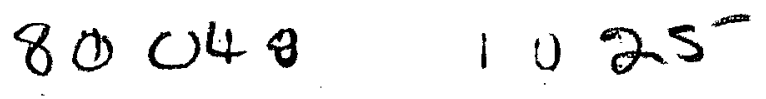




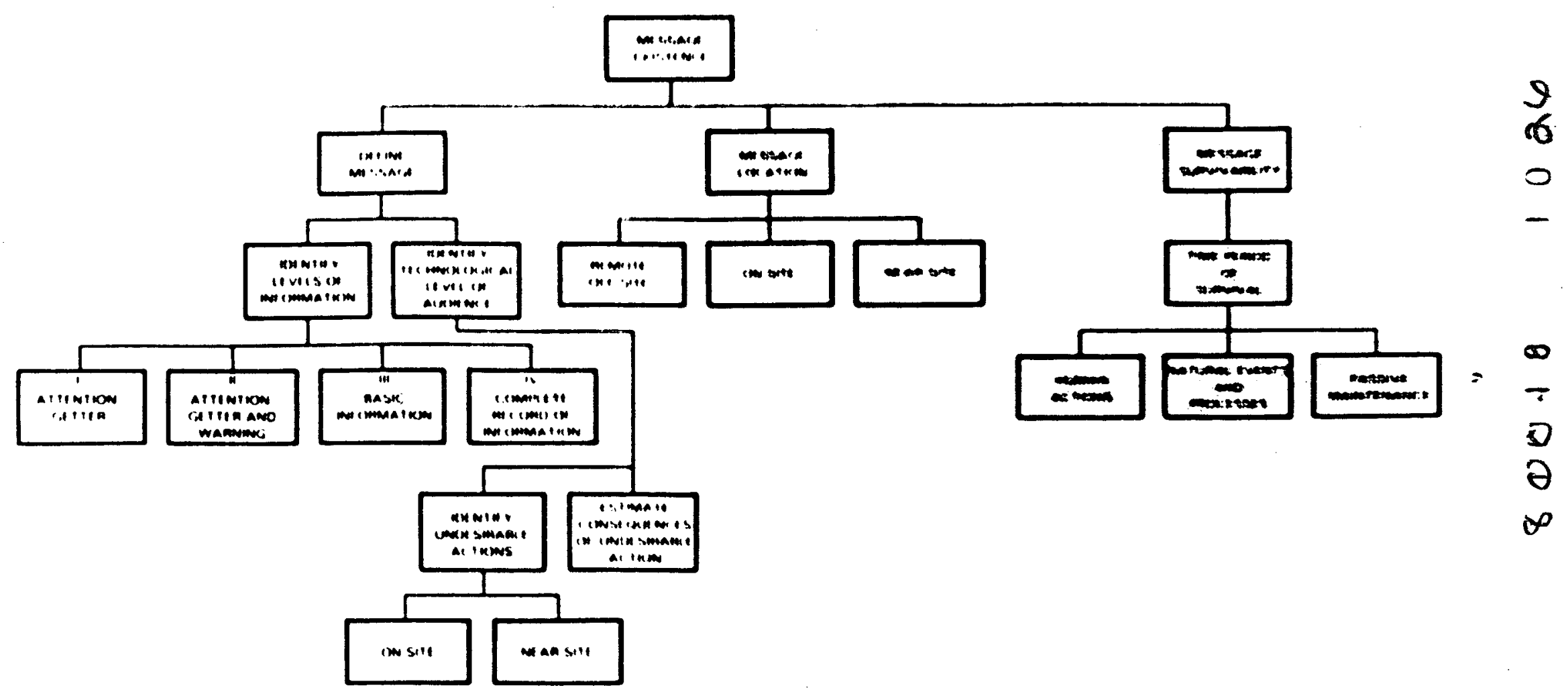

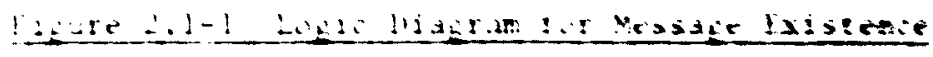


Information, but the Level II tiformation is los:. The difierellt ievels ist information, therefore, may requlte different malid ind metlods if presentaton in order $(0)$ he effective.

Another aspect if message definttion is the identification of the audfence to whon it is addressed. For the purpose of repostiory wacking. the technological level of the audience any affect how the aessage is struitured. In particular, the technolnglcal level may affect what is mentioned as actlons to avoid in the level III and IV ressages.

It therefore follows that an intctal step Ia identifying the technoling cal level of the audlence is the Identification of undestrable acinns to that warnings agalnat then may be made. These generally fil into two intexweles: direct Intruston into the ste ltself, and nearalte activities, Direct

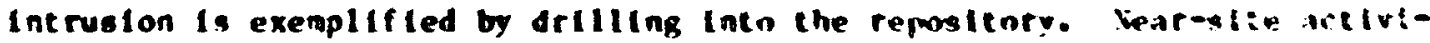
cles, though not at the stte itself, conld dininish the effectiveness if the repostory gystew. An examle of nearofte activitied is infection nf suhstances Into the overlying aquifer wich would redice the abliti of the lifulfer to retard the transpore of tadiotiotopes.

The boundartes of the firat category of undestrable actions fatrect Intruxion) are well defined, since they are set by the areal extent and tepth of the repoutiory. It in untikelt that those wil change radically witith the

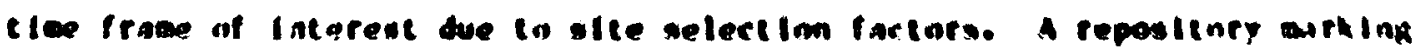

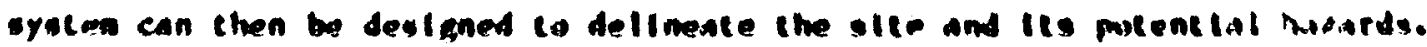

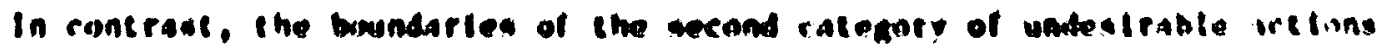

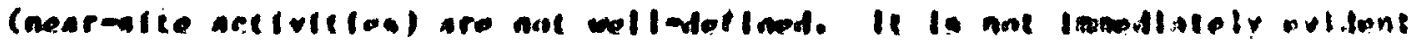

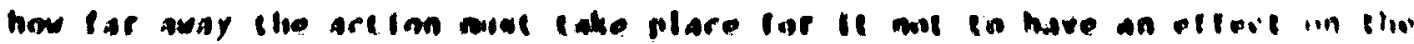

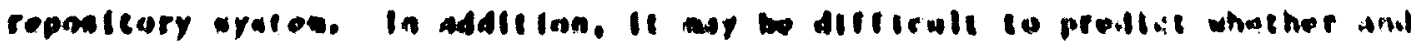

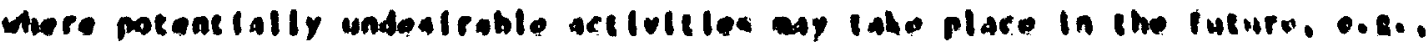

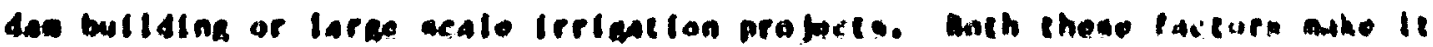

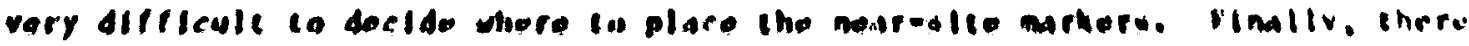

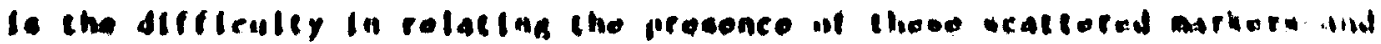

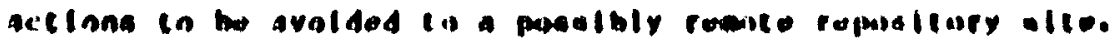

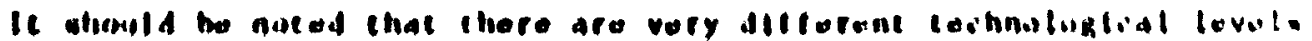

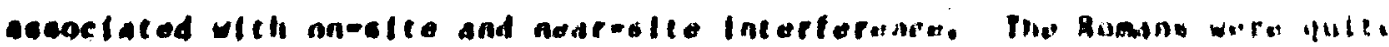

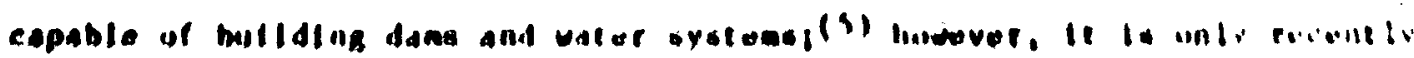

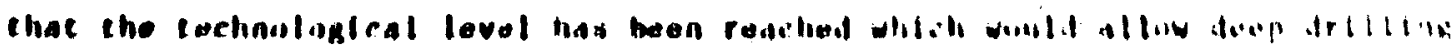

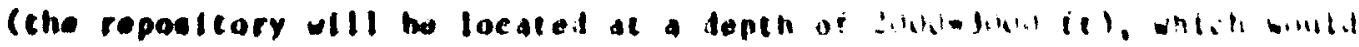
conetluce on-atia incorferanco. 
The stte-spectfic safety analysis which would be undertaken at a repostcory site could ho "lt llized here. First, the analysls would consider thise actions and their consequences which would be detrimental to the reposifory systen. This work may also faclittate the Identification of a buffer zone around the reposttory to protect against actions such as drilling. If this can be done, then the reposttory stte, plus buffer zone area, would be the area to mark. This stlll leaves action whlch may take place at sowe further distance from the site, e.g., das milding, co consider. The safety analysis could deteraine the severity of the consequences if actions such as dam building were taken. Given the potentlal difficulty In marking such a nearsite ares and deteral ning the actlons to be avolded, the results could be used as part of the site selection process, l.e., to judge wether a repositury should be placed at that site. Finaliy. this Inforation would be sultable to inclide In the Level iv message so that future gemeractons could ake an Inforaed dectsion on whether to take a certain action.

\section{1 .2 Messase Location}

All four message levels should be located on the repository site. In order to phystcally connect the concepts of "nuclear caste burlal" and "burlal at this place”. An nent toned in the Introduction, this report It prianilly concerned with the onolte arting of the reposltory and so shall mnit brlefly

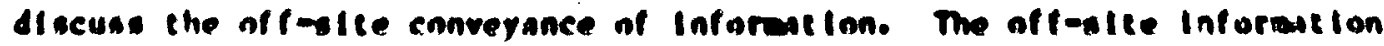
should be located in muerou places, preferably worldatde, in Increace tho

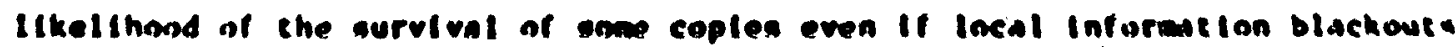

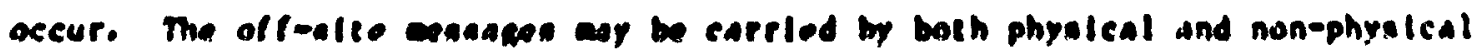
mana, e.g., oral eradition and archival atertal. Level Ill Intormation can

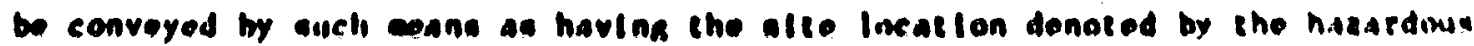

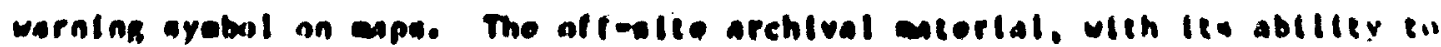

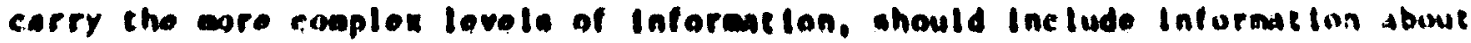

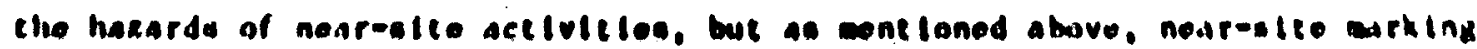

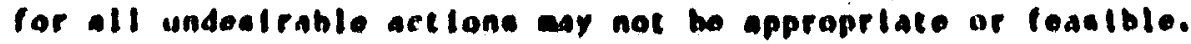

\subsubsection{Menaage Rurvivabilily}

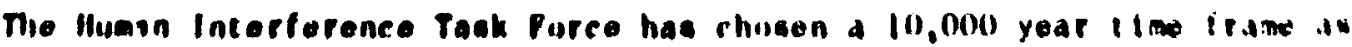
tho porind for which tho eartere nood to eurvive. hased on Rpa drate
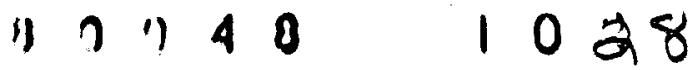
criterla. (1) There is a distinction drawll here between the durability of a message and the abllity of that messige to survive. Ditrability refers to the Iongevity of a miterial if ll Is left undisturbed ifter placement Survivabllity tikes lnto account not only the durabiligy of a moterial, but lis liketthoid to withetand human actions is well. As such, survivahtlity reflects a combination of factors, each of which is described helow.

Archaenlogical evidence Indicates that huarn actions are a prlac fainr to consider wen assesalng the potentlal survivabllity of the miker system. This factor can affect the cholce of aterlals; wetals ay not be siltable because of their ablilty to be recycled (cf. Sections 3.2 and 4.1 for examples and further discussion). Removal, defacenent, and vandallsa are all posslbIIitles to be consldered. Chapter 3 contalns exaoples of what has haprened to some notable conuments at the hands of man. The reasons for rewuving or Jestroying wonuments are varied, rangling from Iconoclasn to musetu acquisition, and the arker system mat be designed to ake removal and/or destruction undestrable or difflcult to do.

Human actions can also Indtrectly affect the durablitig of arker. For exapple, Induntrialieation has led to actd raln. wich Is having an adverse effect on any anctent amonts (section 3.1 .5 discusses Ita effert on thr conument of the Acropolis. Creecel. The enther components muse chisen with this phenosenon in at nd.

The arker gyetew should also be able to withatand the mecurel event: and

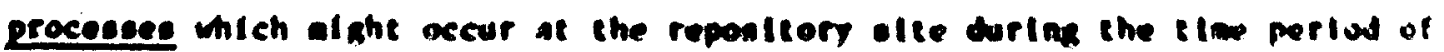
interest. However, In some cases, this ay not w feasible. For evample. It

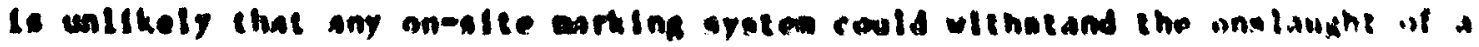

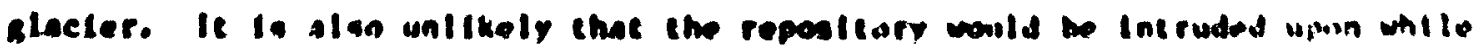

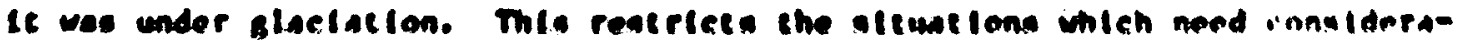
cton to ehose chere a clacter could advance. retreat, and have tire after the

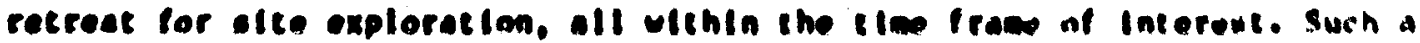

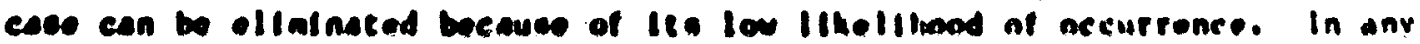

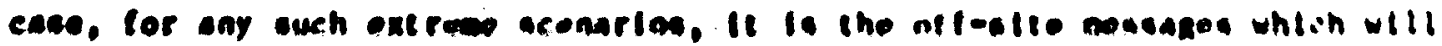
conctinue to convey the Information.

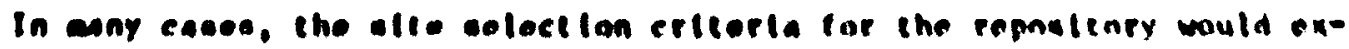

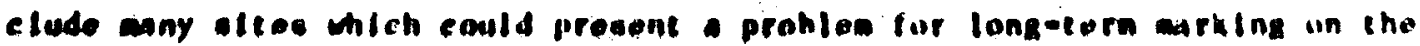

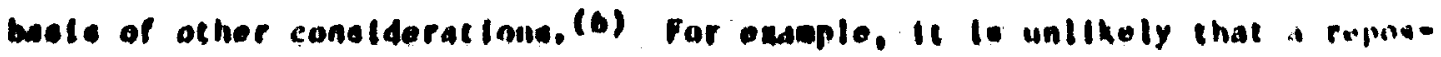

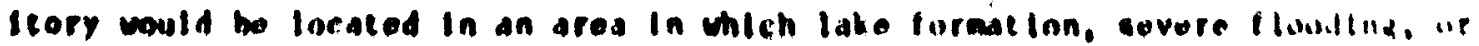

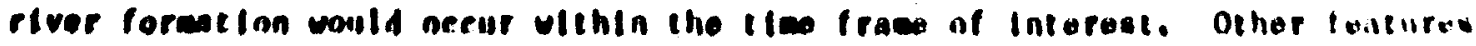

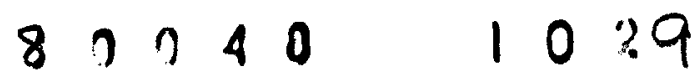


of the marking system, e.g., helght of the markers, or whether they should be placed on platforms, could be chosen with consideration of site-specific factors such as soll erosion or deposition rates.

Finally, the marker systed mst requite no active alntenance. Such maintenance cannot be guaranteed and to requite te would be contradictory to the Idea that the generation which recelves the benefit of nuclear power should place no burdens on future generations for Its disposal.

\subsection{MESSACE DETECTABILITY}

The pessage wat be noticed in order for It to be effective (Figure 2.2.1). This brings us to the questions of the distance at wich the bessage should be detectable and the exam by wich it ahould be detectable. (As otated earlier, this discusetion is concerned with the bessege at the repository elte itself. It does not conblder off-olte Informtion such as warning syabols on aeps or reports etored in (Ibrarlee.)

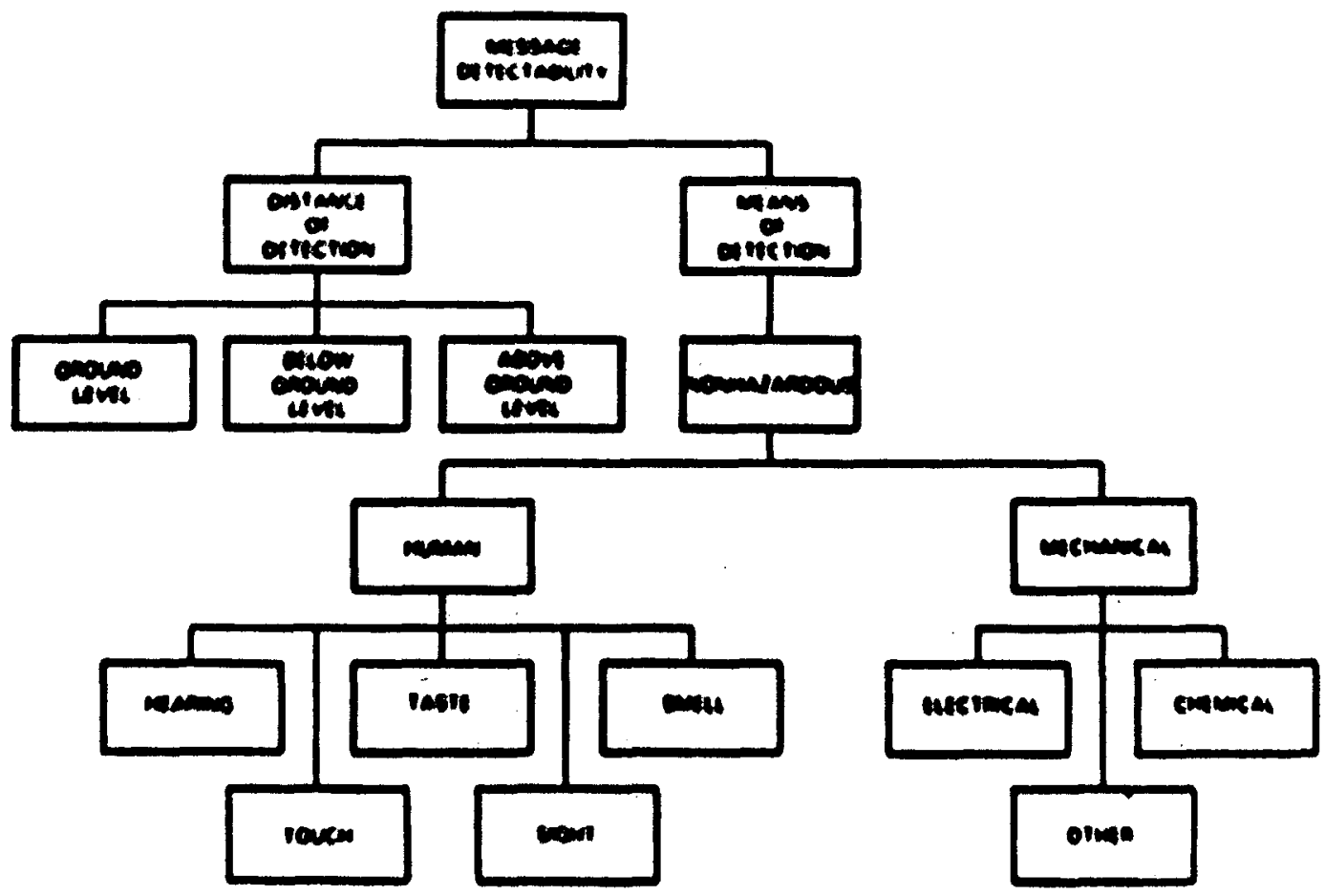

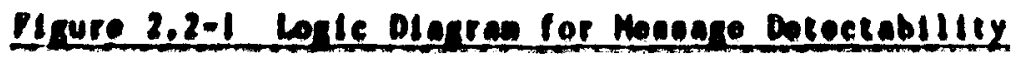


The distance at which the message is detectable may be toi.roi hed, in

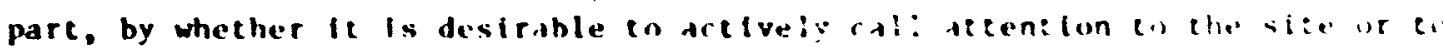
warn people once they have decided to Investigate the ired. For ex-mple, It to Is destrable to call atcention in the ste and have te be defectable by recote cethods (e.g., acrial or satellite detortion), It is posslble to tike such weasures as creating a manetic anowly or changing the vegetation th the stte. Such an approach could carry level 1 or ievel It inforasion (if the unusual festure takes the forn of the hazardmis aterlal warning syabil), but no higher levels. This approach, however, agy trlgger further inves: fzatiuns of the area were none had been prevtously planned. It way isu be superfluma level of redundancy In the marter system destgn, atace whther the reposttory I knmon or nnticed at thls distance will not affert the thavlint

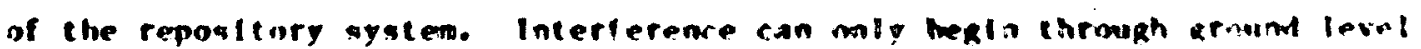

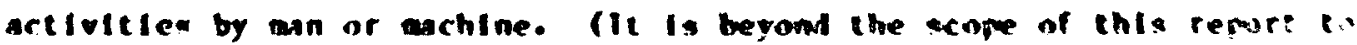

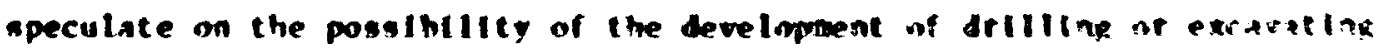

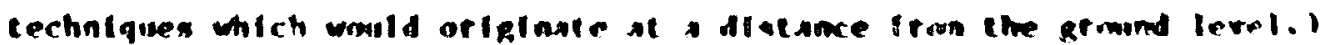

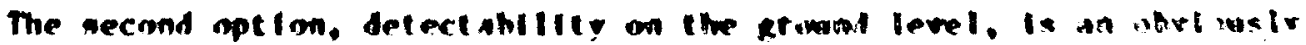

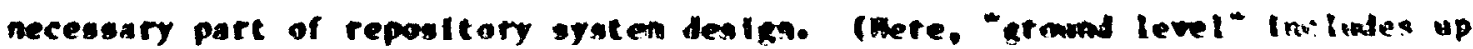

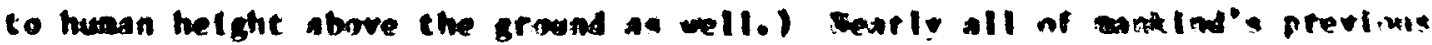

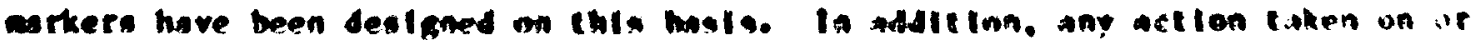

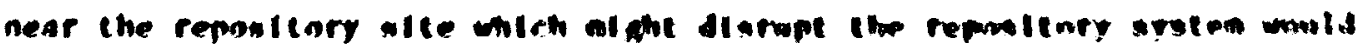

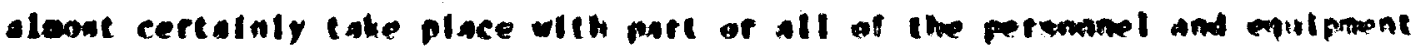

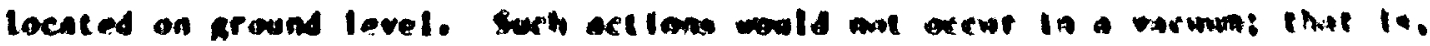

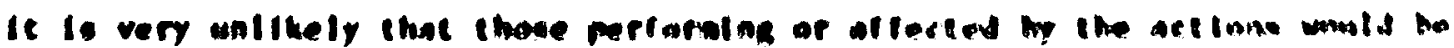

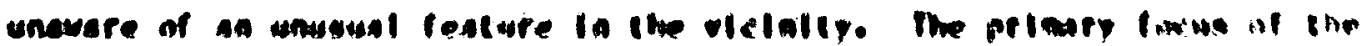

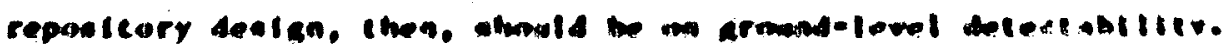

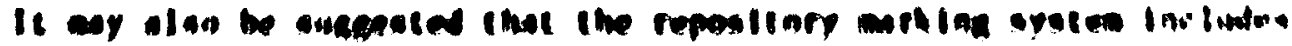

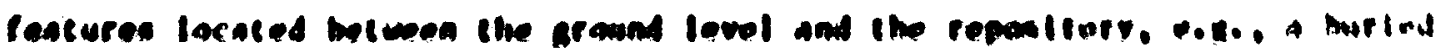

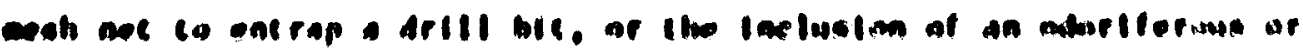

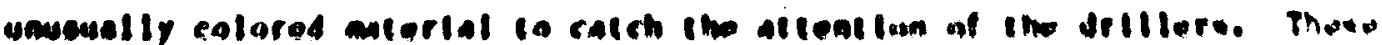

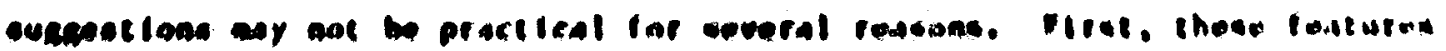

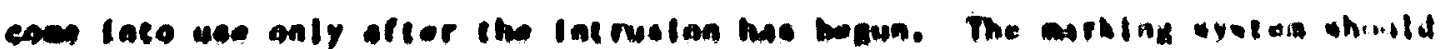

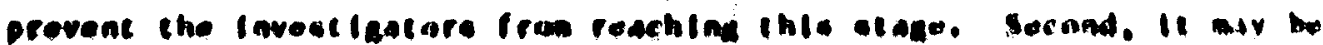

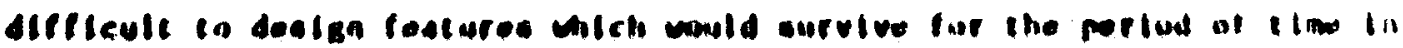

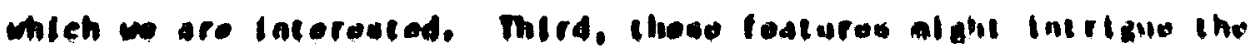

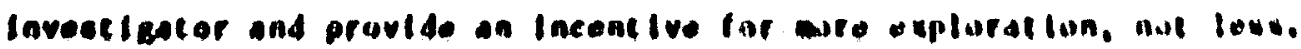


There are two keneral meaus of message detection: by hurdns is by asihine. In elther case, the weans of comunlcating the message cannot be hazardous or requtre in energy supply In order to function. The human means of detection, the five senses, provide us with a baseline for the design, since these are not expected to change nver the twe perlod of incerest. It in difficult to concelve of a essage and/or warning which could be conveyed to the senses of hearing. tasting. saelling, or touching which would be practical, nonthazardous, and passive. Gilte the oppostce is true for the sense of slght; the anclent womments and arkers which have survived appeal to thin sense. It is for this reason that the priary exphasis of the desigi presented ia Chapter 4 Is based upon detection by human sight.

Detection by achines can occur by the Interception of rartous iypes of signals, e.g., electrical, agnetlc, chealcal, and so forth. MIs approeich ay not be practical for several reasons. It is not posslble to predict whit type of signal ey be searched for by future techmologles; It way be one whlah has not yet heen developed. Some algmals, e.s. gravinetic, wat be extremely difficult to implewent, wile others. e.g.. chentcal, may be hakardous. The reailning pomibilities, surh an creating a anget lc or soll resistivity anomaly. can carry onty the IIrat two levels of laforation. For these

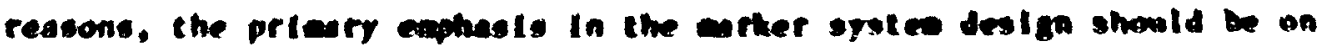
decection by wint.

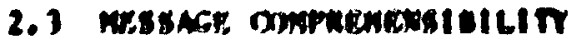

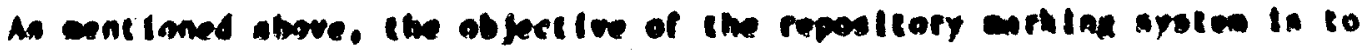

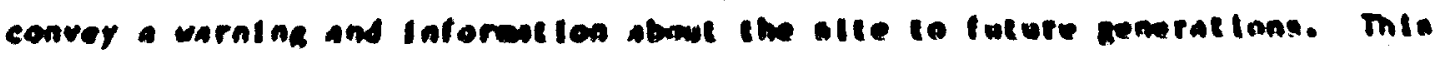

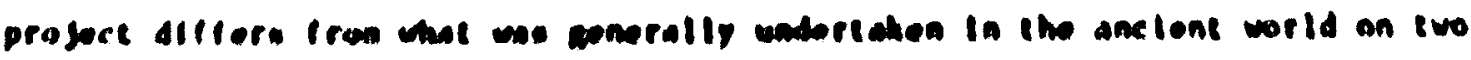
polate.

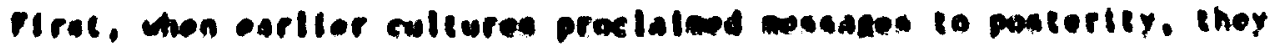

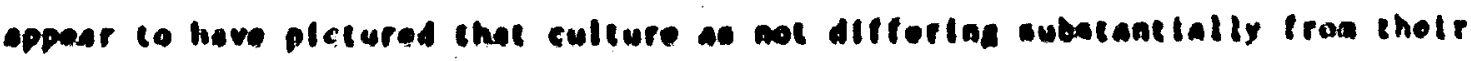

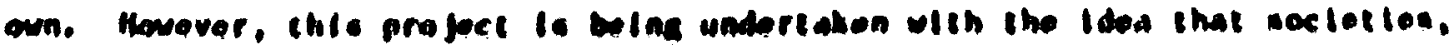

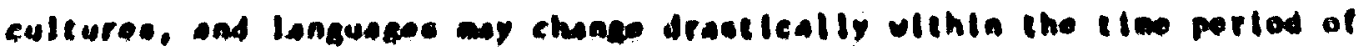

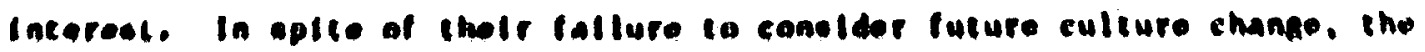

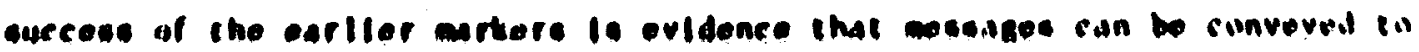

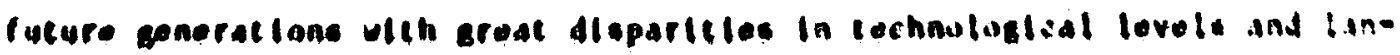
guages without overt offorts in this direction. It is sugesesed, thorefore. chat the repalengy arking ayetem has a higher probabllity of aurvival 
and understandabllity since tt ts belng deslgied with culture chinge ia aind. And, since we cannot predict the changes whlch wlll occur, we cal use aur present languages as part of the wessage and kiow we have done an whte char: the ancients.

The nessage wst not only be understandabie, but bellevable. This is a second difference between previously ade wessages and the ones designed for the repostiory systea. The anclents placed warnings and lapediane-s in the way of Int ruders because there ws sonething for the intruder had reason in thind there was sosething) of value stored In that place. The bulldets deslgned a curse or threat to frighten off persons who sought the vealth. That their curses falled to drive of tonb robbers can be seen In the vide extent of this type of intruston. The excavation of the tow of folankhaten created such a etir because It had been fifled only In a ellor way. An exampla nf warning agalnst int rugton is the text glwa below; meedless in say. the Inscription was found over an expty tobs.

1. Tabnit, prteat of Aoterte. HIn of sldow, the son of

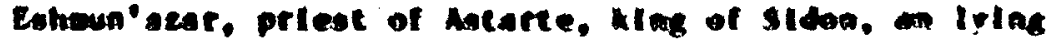
In this sarcopthagas.

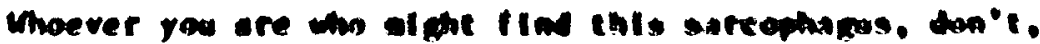
don't open It and in'i alstert se. for wo slliver has

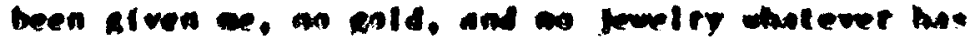

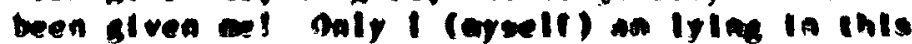
sercephogue.

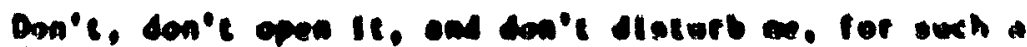

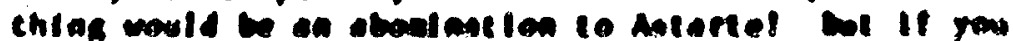

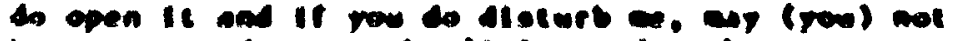

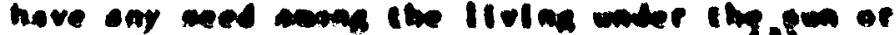

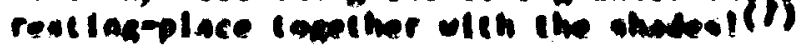

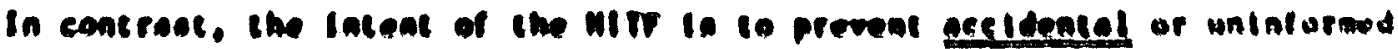

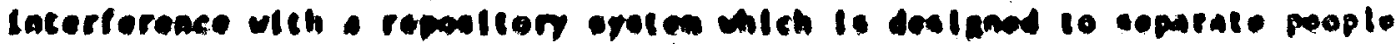

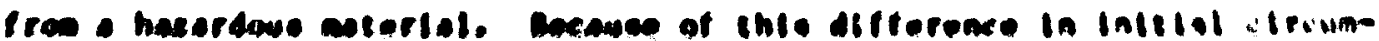
etencen, l.e.. deatrable verous uadantrable cantente. the repostlury it in a

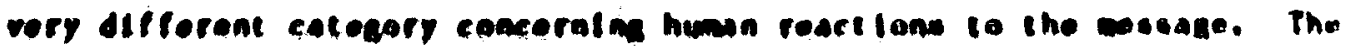
waralng glven in the above tent une prabubly lignored because prlor expertence

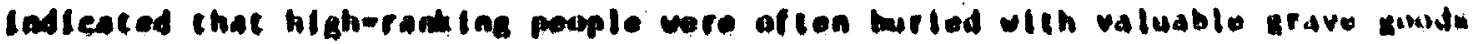

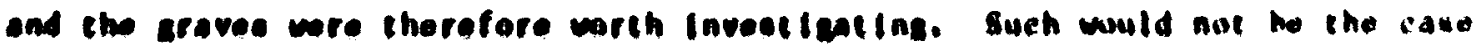
with the repoetcory and its contente. In ather wopds, prtor thilent varnings

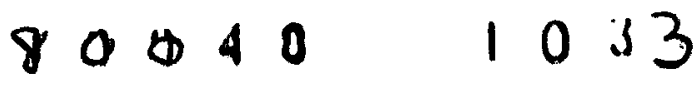


were to protect the tomb, and 1 ts contents, 1.e., Its owner, thile the repostlory system warnlings are to protect the intruder. To thls writer's knowledge, the Intent to mark a hazardous waste slte for such an extended perlod of $t$ ime for the purpose of protecting the potential Intruder is unprecedented. It cannot be guaranteed that the Investigator will heed the warning even if it is understood. An analogous sttuation is the warning placed on clgarette packages. In either situation, the Individual or Investigator bears the responstbility of his or her actions because the decision to act was taken with knowledge of the potent lal conseyuences. (4)

The eaphasis in this report, therefore, is to ake the message as comprehensible as possible over the the frane of interest. The nessage may be conveyed by three different means - syobols, plctures, and by languages (F1gute 2.3-1).

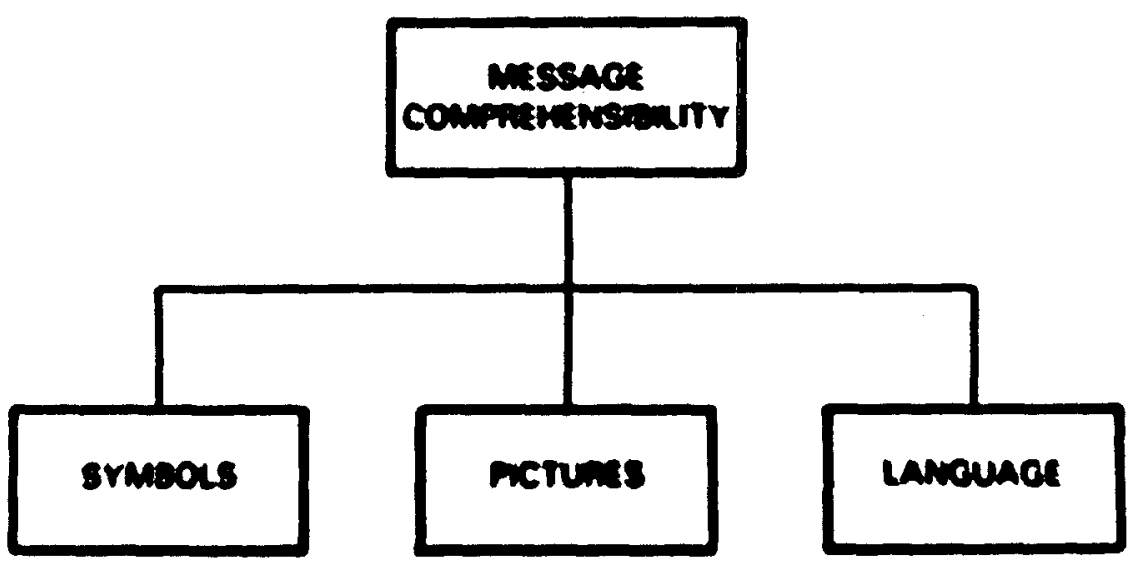

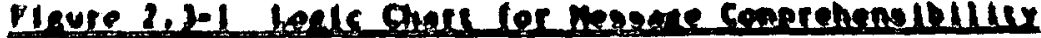

Byebole can be ued to convey level 11 Information on the wlte lisell and

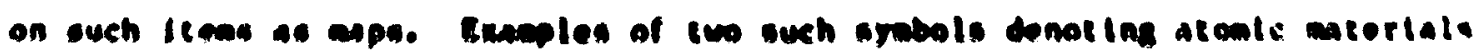

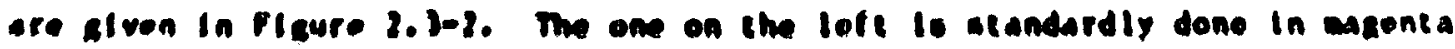

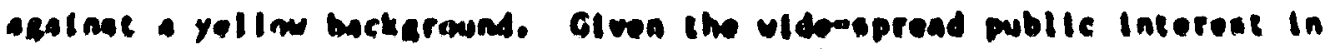

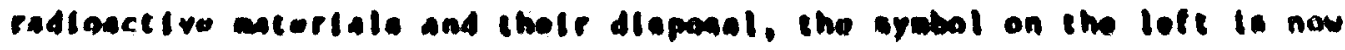

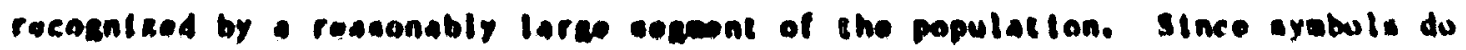
nol coly on language. they ay be more adaptable for panculfural usos auch as this, althaugh they aust tearned by the publte.

$$
80418 \quad 1034
$$



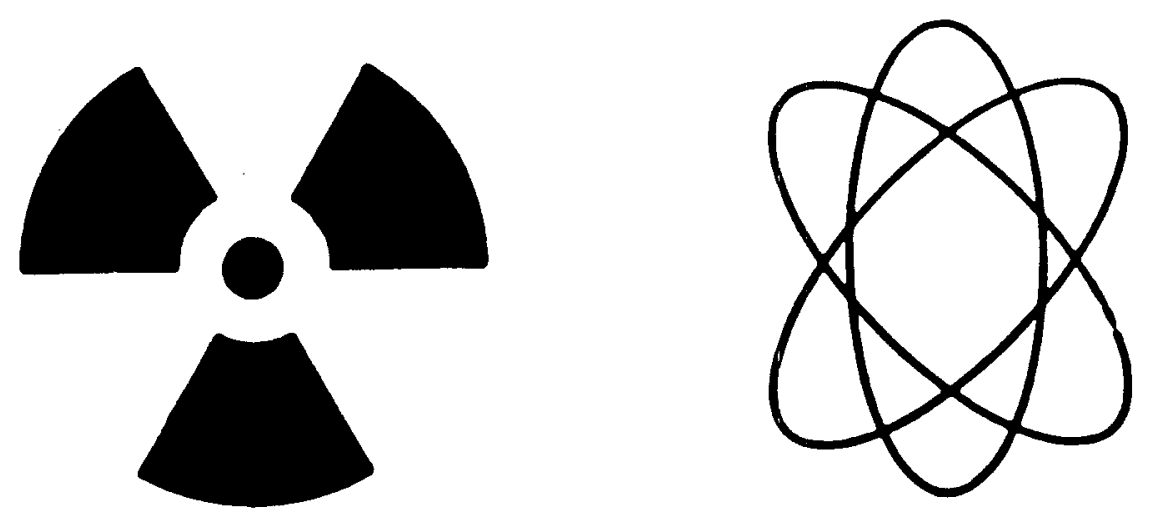

Pigure 2.3-2 Exagple Srabols Used with Atoalc Materials

Plctures are an obvious wenns of cocmualcet ing information vithout written language. For example, Figure 2.3-3 shows a statve bing drazked by eany people, socething which is disceralble even though wost reeders of inis report cannot read Expptian htercalyphs.(B) (since thls sceme comes iron a 3,800 year old toob. It is en excellent Illust ration of the polentiat for comounication to future pencrat lons.) Although it it cotslite the scupe of this report co develop a plctorial representation of the repostiory orstea. euch a represent at Ion showid be lacluded in the omplier orstea.

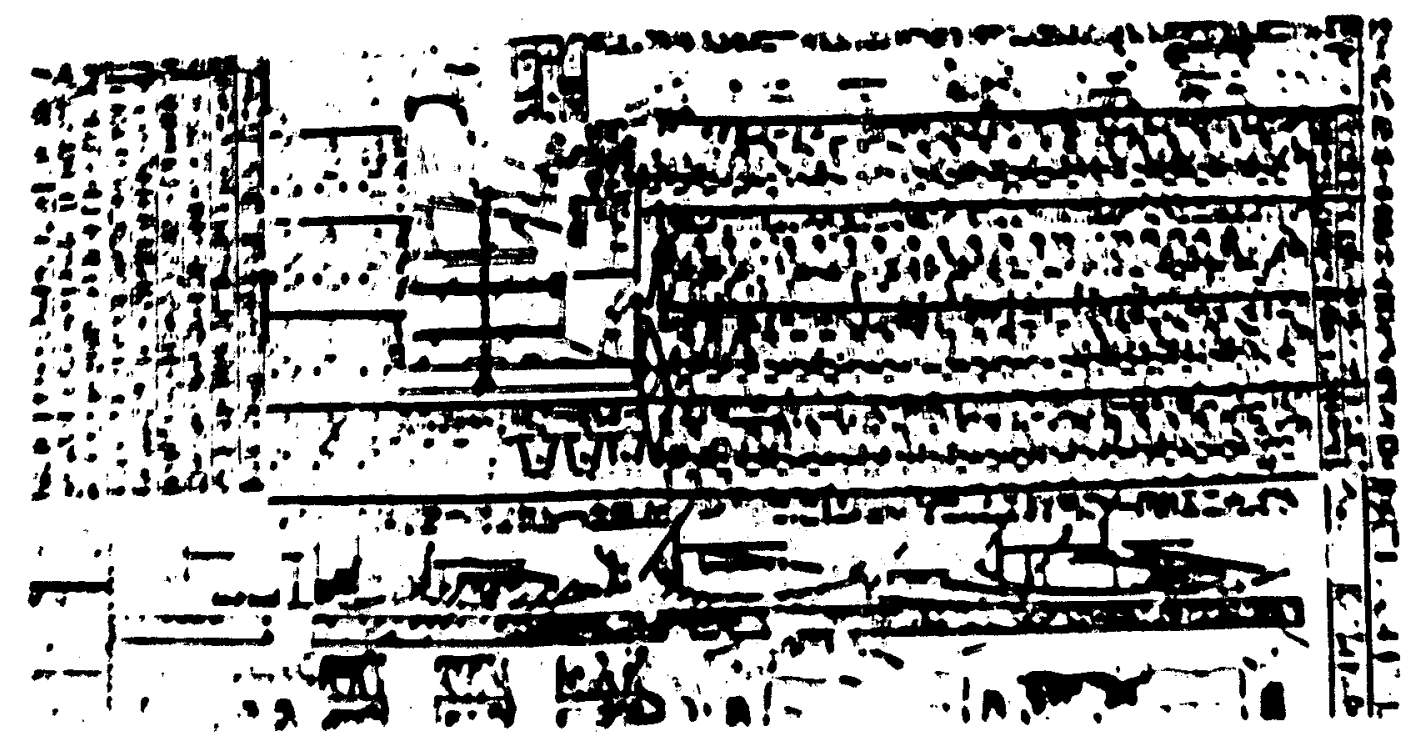

Pigure 2.1-1 scene pron Tonb of "Jehulyheles

$80010 \quad 1035$ 
Language is the third option for conveying information. ifven the the trinc involved for repositury markers, it is extrewely unlikely that finglish will not evolve significantly frue its present form. For example, wost nat ive speakers of Finglish can read Shakespeare (c. 1600 A.D.), a few can muddle through the orlginal Chancer (c. 1400 A.D.), but most could not read the welginal Beowolf (c. 700 A.D.). Yet it should not be overlooked chat the latcer two llceracy works exist in modern translatlons and are therefore avallable to a wider audience. A stallar phenowenon ay be seen in the translations of the Greek and Hgyptian ayths and historles, as well as the burial Insiriptinn quoted above. There are imo points to be noted from this phenomenon. First, It appears that if the message is of sufficlent interest. It wll be translated or "re-encoded" Into the languages used at that the. If the ievel of interest in the dinposal of muclear wate is indicative of future Interest. the message is likely to be recencoded. Second, the message need nut be laneAlately readable by all wewbers of the general pablic in order to have the Inforation survive and be disseatanted to that poblic. As long as sume people can read anclent languages, the wasuge can be cransiated for the zeneral public.

In other words, we should metther ovellowk nof dowplay the potential for lancuese to carry inforaction about the repostiory. Language also hat the pocential for conveying finer lewels of Iaformation than is possible by the

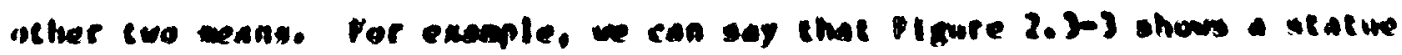

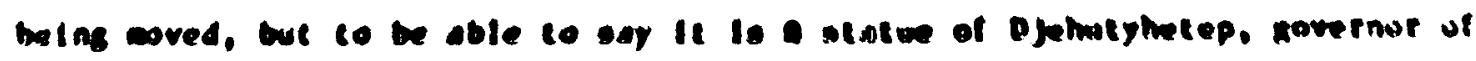

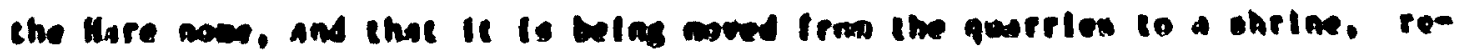

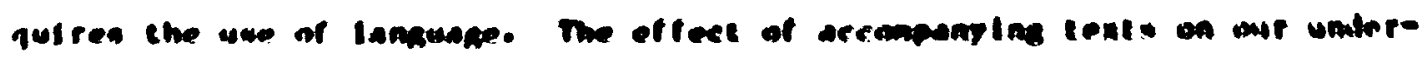

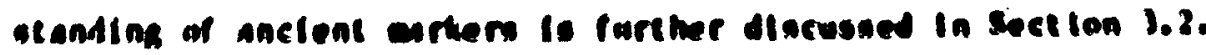

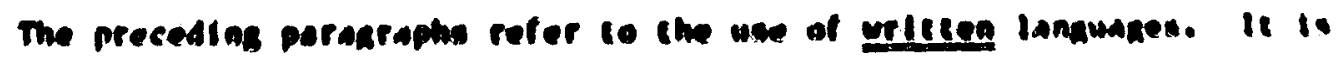

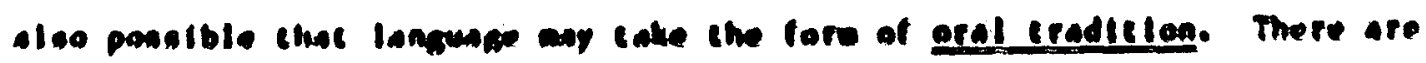

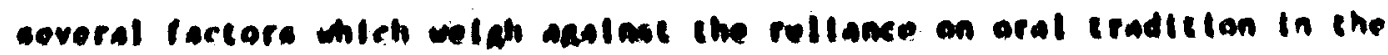

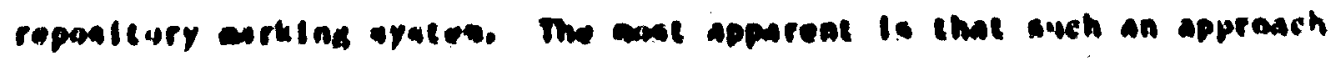

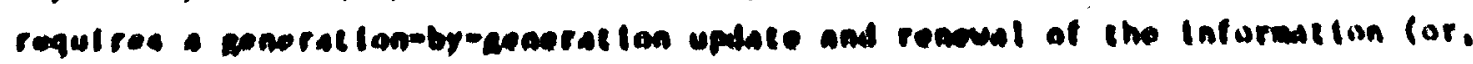

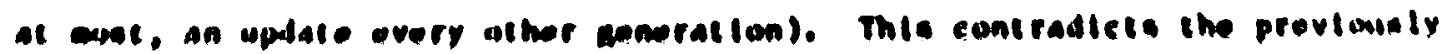

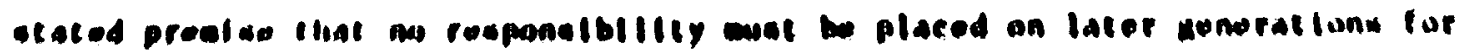
the ariting of the repostiory elte.

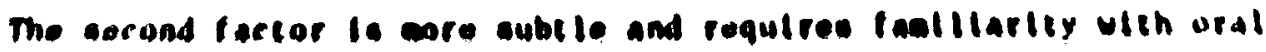

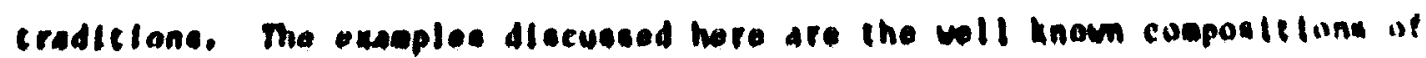


Hower, the lliad and the odyssey. There Is little doube that these wer. orlginally ord compositlons. There wete adng versions of the Homerle epilis when they were first written down, c. fifth century B.C. There were ttienpts to collate, reconclie, and edit the varlous versions by the third century B.r. Even after the sutstanding work of a Howerle critic in the second centur: B.C., there were silll "wlld" texts (1.e.. Chose which differ in lengeh ur lu substant lal wording of the (ext). (hough these now were wore the exceptiun than the rule. (9) But once they were written out, It was the literary tradition, not the oral, which preserved Hower's eplcs to our tive.

Research and atudies of modern alngers of tales". priatily those in the Balkans, are the work of Parry and tord, and it Is useful to qunto sime of the latter's coments:

If the singer of oral eplc tradition always ang a snnt In exactiy the saoe worda. It would be possible, of course, to ank his to repeat the perfornance nuber if t Inea .... but bards never repeat a nom exactly....

Those singers who accept the ldea of t ined teat are int to oral craditional processes. (10)

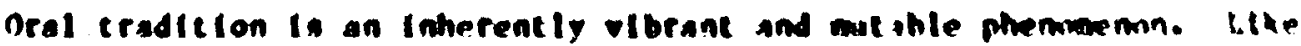
language itgelf we cannot control the ways In wich it will antate. nup how it wil change with each generation of iranodsolon.

Moreover. Lord Indiratea thot the oral and Itteram iraditions of:

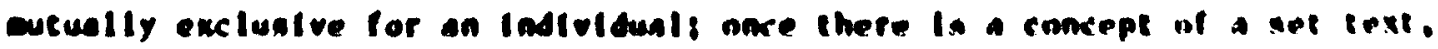

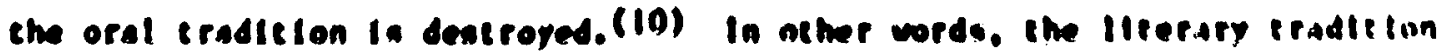
supplanes orat craditims the iater ta not of tea aftiliated otith an

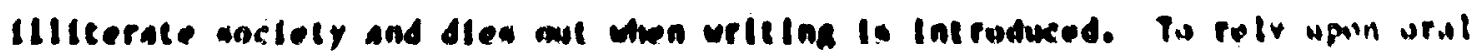

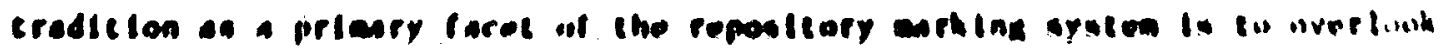

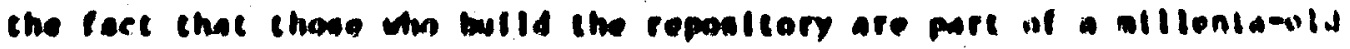

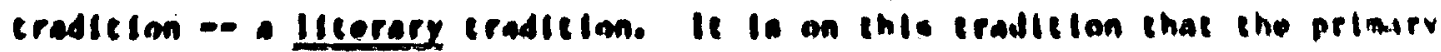

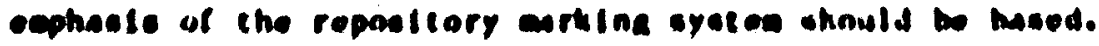

There are coveral guldoline chleh it bay prove whoful to follow in

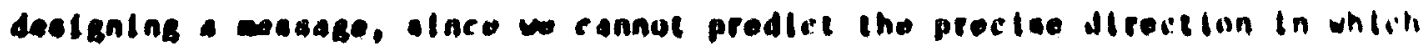
languagea will evulvel

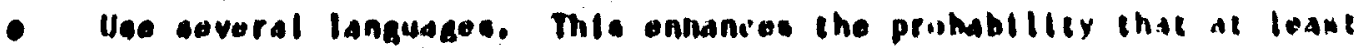
one of then vill be reconglabble and dectphorable. 
- Vse languages currently in widespread use. There are more speakers of Finglish or Spantsh than there are of Esperanto, although the latter is an artifictal language designed for International use.

- Try to avold jargon since it has a lialted audience and lingulstic IIfetine.

The use of language, In conjunction with syobols and plctorlal representations. should provide the weans for conveying different levels of informatinn about the repository. This redundancy In the design will enhance the posstbllity that the inforation will be comprehensible to future investigators.

\subsection{SUmarary}

In the discusstion of the potent lal probleas of huan Interference. there are several aspects of reposttory urther syste dealgn which rest upon factors deternined outside of this report. e.s., technological level of the audience. and distance of detectablity. Several goldelines, hourer, become apparent. civen the difilculty of correlating the repostion with wearstie fectures and detricental actions, the ala ecphests swowid be placed on onting the reposi-

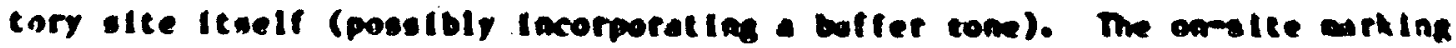
yyaten showid Incorporate all foup levels of Information (1.e. Iroo an

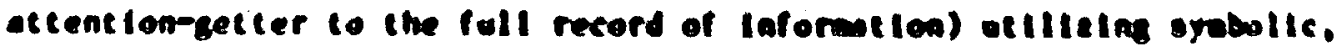

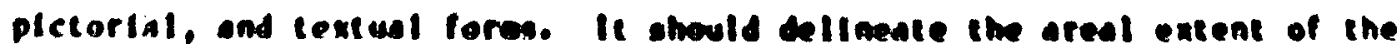
repostigry, be priapily detectable by olght on groond level, and be wade of

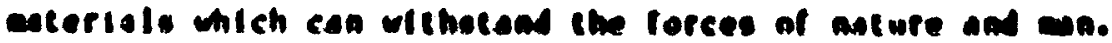


6

14)

3

ARC,IAEOLOGICAL MARKERS

This section will investigate several ancient, wantage monuments.

Section 3.1 is primarily a marker-by-marker description, providing the Information and background which is draw upon in the repository marking system design presented In Chapter 4. The markers were chosen cu represent a variety of cultures and climates; the former to indicate that the asking of convents and their survival is not keyed to a particular culture, and the latter to ascertain the effect of climate on survival. Since we are Interested in survival, each of the markers had to be at least one thousand years old. Some, as we shall see, are five times this age, which Implies that they have already lasted for half the tine period in mich we are interested. These markers are:

- Pyralids, Egypt (Section 3.1.1)

- Stonehenge. England (Section 3.1.2)

- Nazca Lines, Peru (Section 3.1.3)

- Serpent Mound, onto (section 3.1.4)

- Acropolis, Greece (Section 3.1.3)

- Great Mall, China (section 3.1 .6$)$.

The Information will be sumarlice of on appect-by-aspect basis in section 3.2. Including arterial used In construction, gl ce rance, and the effect of contemporary tents on our understanding.

3.1 selected sxarpess

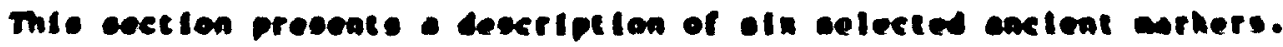

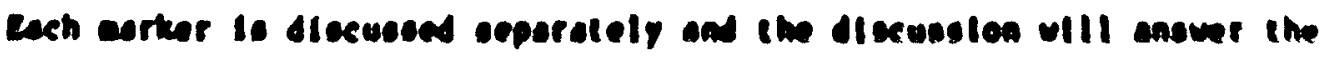
following quot tones

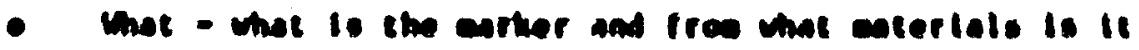
anoulacturad

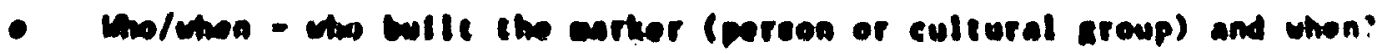

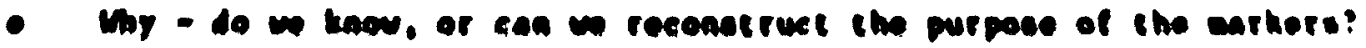

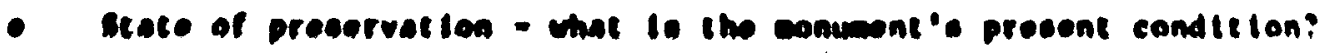

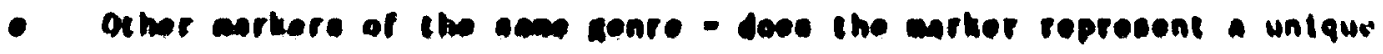
feature mich survived, or does It represent an exemplar froe a number of surviving enrkere?

$80010 \quad 1039$ 
- History - how far can we trace the hlstory of the minument?

- Relevince - what cian we learn fron the ronument wiliti would be Iseitil In dosigning a repostcory marking sustem?

\subsubsection{Pyranids, Egypt}

A wention of "tgypt" confures up laages of the Sphinx and three enurious pyranlds at Giza near Calro (flgure 3.1-1). The Greal Pyraald was bulld by Khufu or Cheops, as the nase is preserved in Greek historical texts. It originally masured $756 \mathrm{ft}$ on a side and stood to a helght of thil ft. It now stands $450 \mathrm{ft}$ tall and $750 \mathrm{ft}$ on a side due to the Ings of the casing stinnes.

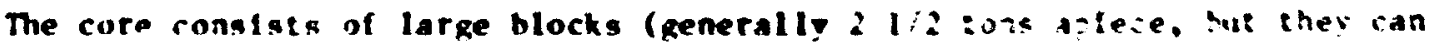
range up to 1 ; tons) of local Itmestone taken from a nearby quarry. The casting was of a finer, witer limestone quartied from the other side of the Nile. The atonen were so clonely fit tokether that it in difflcult to lacert even a kntfo blade botwen then. The probld underwent three chankes in plan wilie it wan under conot ruction, each asthed by a burlal thataber. The final chamber is IIned, roofed, and pared with monolithic grantic slabs: the ronf

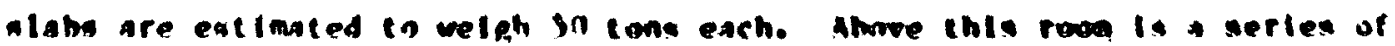

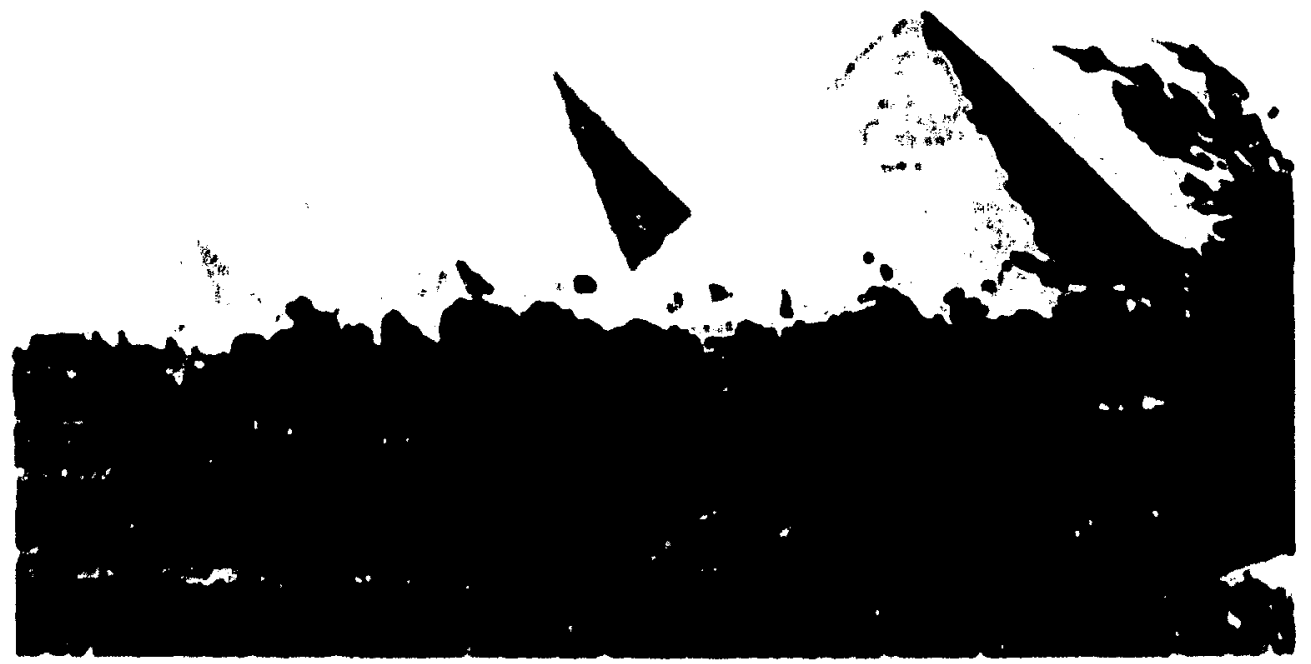

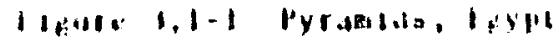

$80010 \quad 1040$


five chasabers lo relleve the welpht of the upper portions of the pyramis irum the burlal chamber. The name of Khufu appeirs in the guarry mirss w: singe if these stones. $(11,12)$

The second pyramid was bullt by Khafre, a son of Khifu, and le orlginally Deasured $708 \mathrm{ft}$ on a side and was $475 \mathrm{ft}$ high. Like the earlier pyrdald i: was eade of a local liwestone core and finished with a white limestone layer. Part of the orlginal casing still reailns on the suaste. The tneernil plan ts staple, with two passagewdys leading to a single chamber. (II)

The Sphinx Is part of the pyraeld complex of Rhafre, but is a unique feature. It appears to be a gifted archttect's way of changing an eyesure into a thing of beauty. The Sphinx lies within the quarry for the liastone blocks used in the construction of the varlous pyraelds and their concuaritent bulldings. The best and hardest stone was chosen for the pyrailds. leaving a ass of softer rock jutting out from the quarty bed. This evesore was cransforned by Khafre's architect into the neatly 70 te tall Sphinx.

The third pyraetd, bult by Heakure. Is the sallest of the inree (356 ft equare and $218 \mathrm{ft} h(\mathrm{gh})$. but Its stee was of fset by the use of grantite casing on at least the lowest inteen courses. It was orlgimally planned on $A$ saller scale since there is a second posagenay which now ends in a int-tesac within the pyraetd structure. (II)

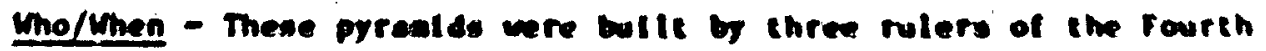

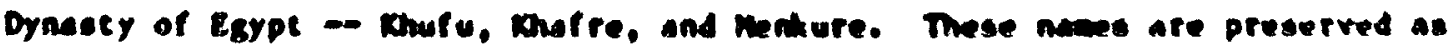
Cheope, Chephren, and Hreerlaus by the Sth centary B.C. Greck hiaterian

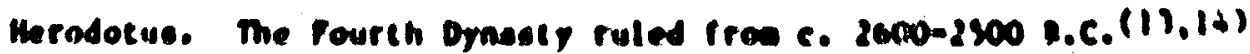

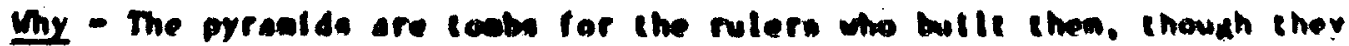

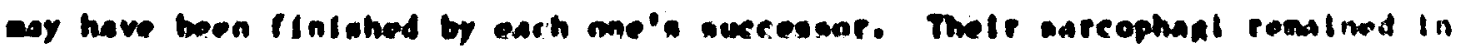

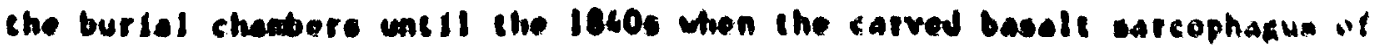

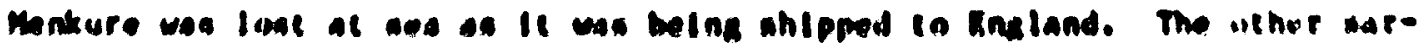
cophagal (both platn) wero aever aved. Thene pyratid were part of lunorary

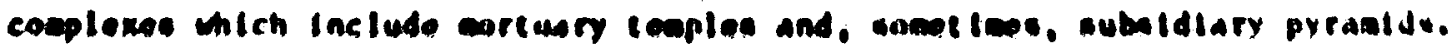

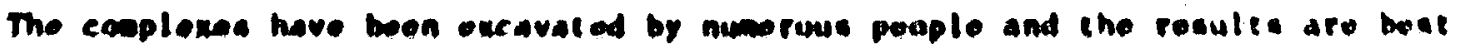
cumertad in rakhry' writ. (11)

Btace of Precervation - The contente of the lonbs wero lwotod In int I-

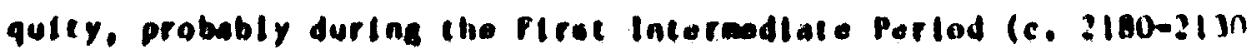
B.C.).(13) the ontertor etructures ape wa topreselve that they ware wne of the seven wondere of the wrid In Rumen times and elll are loday. Ther have 
lost nearly all of the casing of finer stones, and part of the cores have been quarried, but these actions have only ade a small dent in their fmmense bu:k. Much mor: of the mortuiry cemples has been quarrled away, leaving only the lower courses of stone. The Sphinx, made of softer stone, is more heavily eroded and was repalted in antiquity.

other Markers of the Sabe Genre - The three pyraids at GIza represent the apex of a long tradition In Egypt. The earllest pyraeld is the Step Pyramid of Sakkarah bullt for zoser (c. 2700 B.C.). (13) $\mathrm{mis}$ six-layered monument was a sharp departure from the prlor tradtcton of low bench-like structures called matahas, and by the sixth century B.C. Its architect. Ithotep, was delfied for his wisom.

other pyranids followed (there are over $8 \mathrm{n}$ in Egypt). Dy the tae of Snefru, first king of the Fourth Dynasy. the sldes were sloped. The engineers of his pyrauld at asbhur had to change the angle of the slope when they realized that the original design wold have collapsed the cellins of the intertor roons and corridors. It Is now knomp os the "teat Pyratd."

After Menkure, the pharache bult each bore calest pricolds but the trad-

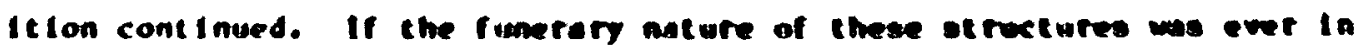
doubs, the alternative hroothees would be disproved by the Frabid Teats.

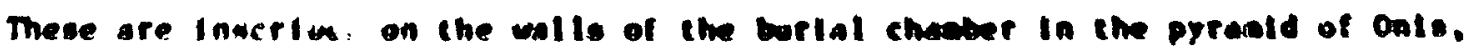
lant king of the Pifth brasety (c. 2330 b.c.) $(13)$, and eccur in all the

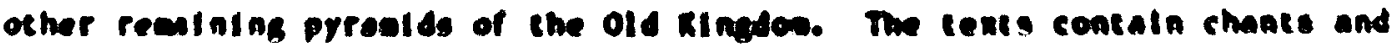
Incentations to Inoure the future hapotons of the ceceased atha. The con-

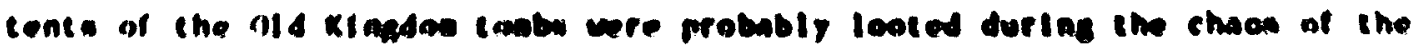

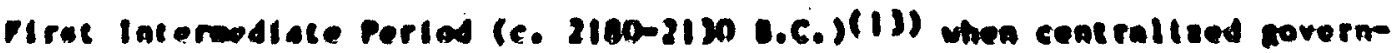

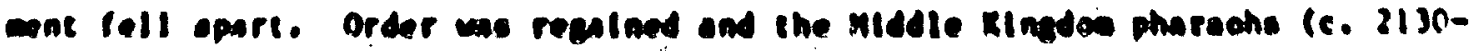

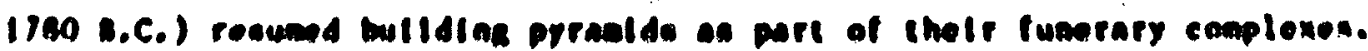

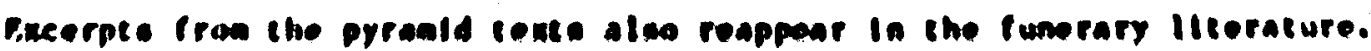
Another portod of cheoe follewed (Secand Intermodiate Perlod c. 1740-1570

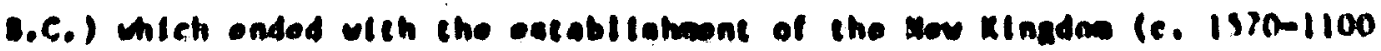

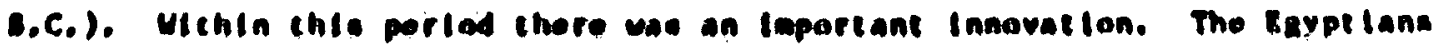
had learnod that the tawering pyrantide at earlier timen cerved as bacona to conb-robbera. Thutmose I (c. 1525 Q.C.) therefore erdered that his toab bo hiddon and the funerary teople be located apart fron tl. successtre pharaoh.

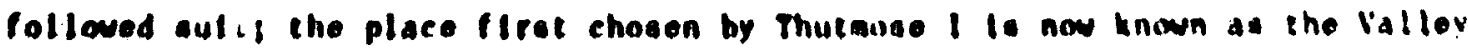
of the xings. Private Individuals, however, continued to suraiunt inelr 
simple tombs with smill brlck pyramids or to laclude a stele with a pyrimita! cop in their tombs. $(11,15-18)$

The use of royal pyramids was revived by Piankl (c. 720 B.C.) of : he Twenty-fifth Dynasty whose capteal was In Sudan. Plankl was inpressed by the pyramids he saw in a alltary campaign in the north and modeled his tomb un thea. Aside from minor changes in forn (they were small, steep-sided, and solfd). these later pyramids differed in that they were bullt for all neabers of the royal fantly, not just the pharaoh. Over alxty pyrawids occur th the st te of Nurt alone, more occur at el Rurru, Lapata, and le roe (all ace located between the Third and sigth cataracts of the vile). Pyrasid butiding in the Sudan ceased in c. 3Sn A.D. with the fall of the Keroltic Ringdon when new religion entered the wile Valley. (11)

History - After it was constructed, the history of the Sphinx is that Thutcose iv (c. 1625 B.C.) cleared the sand away frow the Sphing and bullt brick walls around it in prevent and from re-encrouching. (or thls time l:

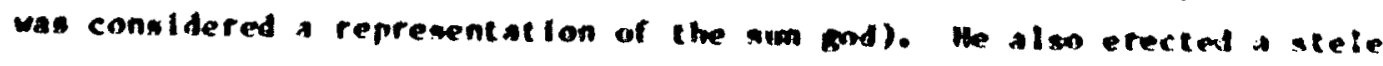

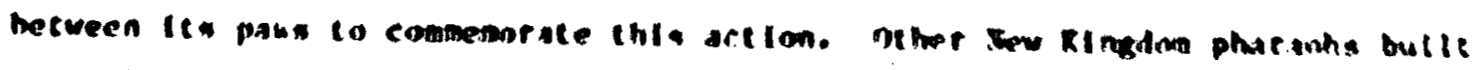
- teople or left wieles or at atwes to the spilax. as dit the lings it the Salte Perlod (66)-323 0.6.). (19) The figure wust have been erouted ir the

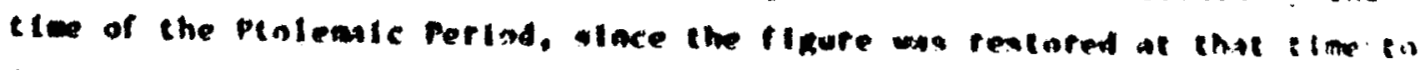

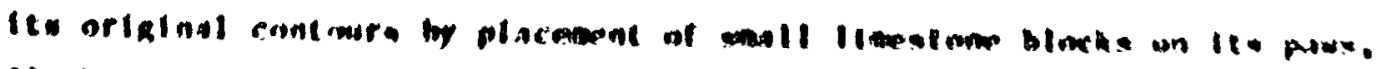

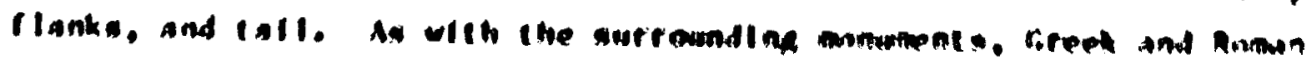

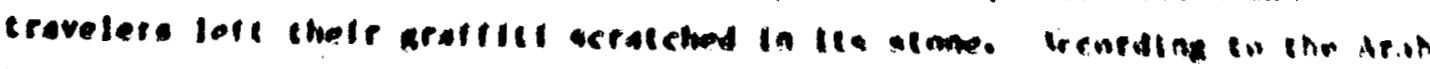

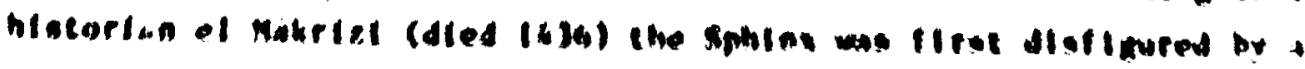

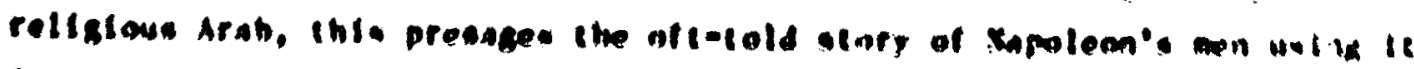

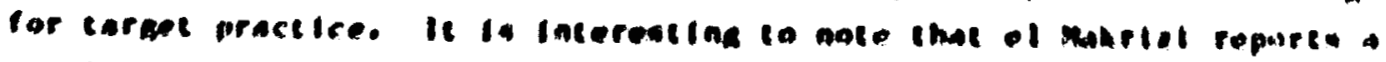

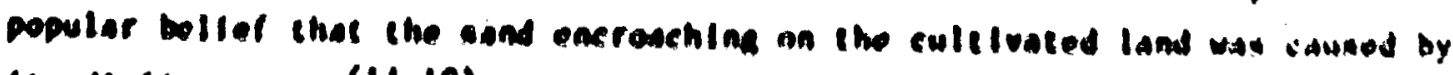
te. dief iguromene. $(11.19)$

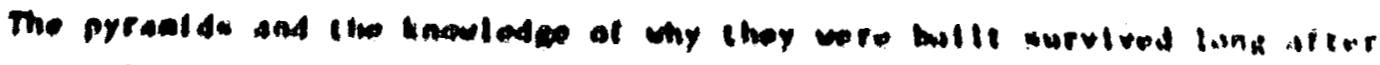

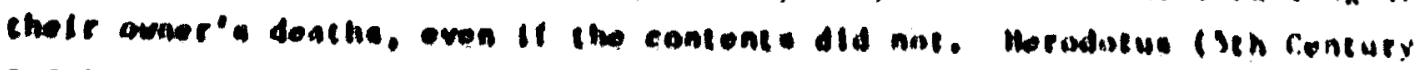

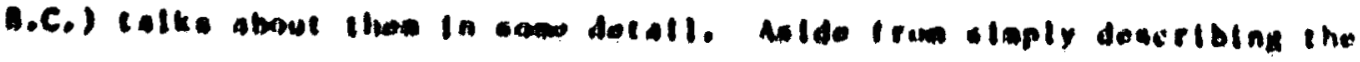

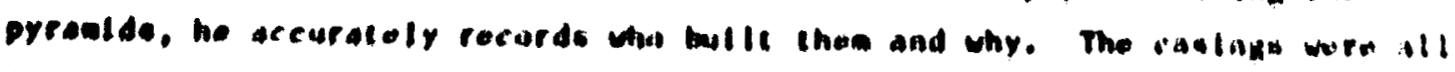

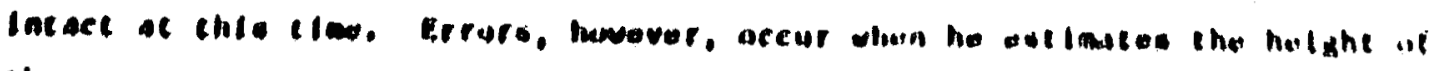

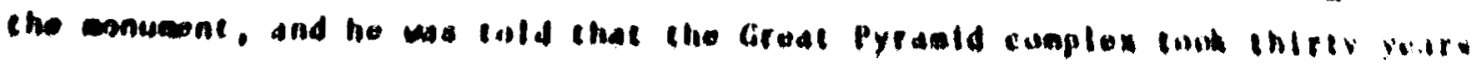

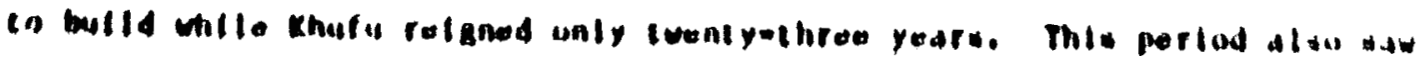

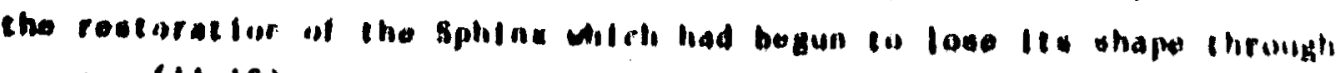
erom $\operatorname{lan},(11.19)$
80048
$10: 3$ 
Diodorus stoulus (a Romin histortan) dis in Egypt from 60 to 57 g.C. Much of what he reports echnes llerodotus. He adds, hovever, that ramps were used in their construction. The remalns of such a rapoccur at the Unfinished Pyramld of Sokhmet (c. 2650 B.C.). (II) strabo. a contemporary of Diodorus Stculus, also visited Egypt and recorded that he entered che Greit Pyramid. (12) Pliny the Fider (23-79 A.D.), saw the pyranids bit he condeaned thea as an Idle and foollsh exhibltion of royal wealth. Pausantus, a second century A.D. traveller, also bentioned that he saw the pyraalds when he visted Egypt. (12)

By the ninth century A.D., blowing sand and debrls had covered the entrance to the Great Pyrald. The son of Callph Harun el Rashid, el Mamun, forced a pasageway through the asonty and found late intrusfre hurlais in the Intertor. An Arab histortan. Abd el Latif (born 1179 A.D.), aentions the numeroux Innctiptions wich covered the casing of the Great Pyrald. These Inscriptionn were lost then the casing stones were quarrled away during and afcer the $13 t h$ century. There wa an atcept armud 120 A.D. to cotally

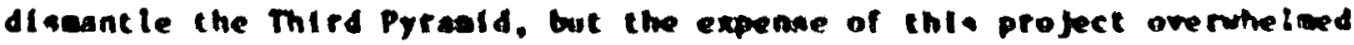
$11 .(11)$

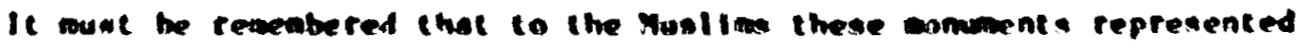

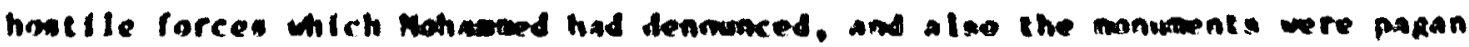
anatheman in the Chrintianc. Sall wonder that they were used an guarrlea for the nearby city of calro. In epte of this the caston of the creat ryraald

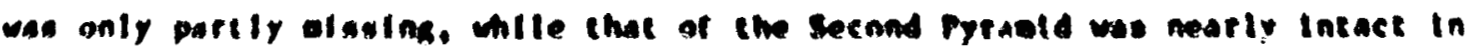

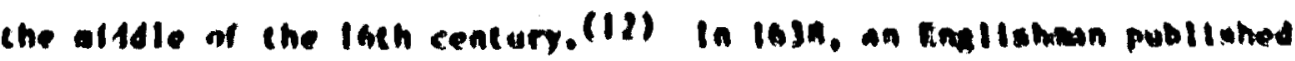

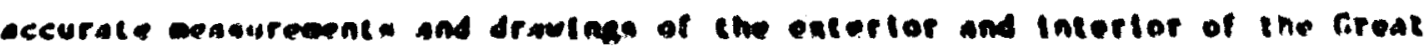
Pyreatd. He concluded that lis functlong were those af a royal tomb and as a

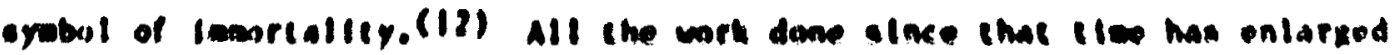

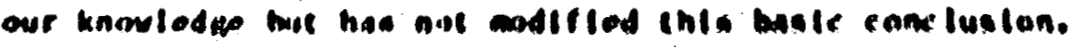

Lelevance - The pyranta enemplify the matblitiy for the conitimity and aurvival of Inforantion tor lang perlodo of elme (5,000 rears). The soction

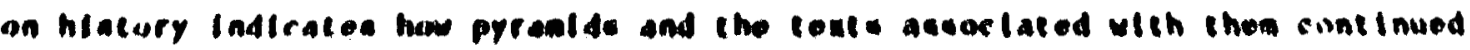

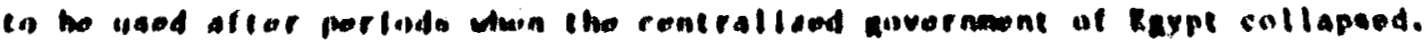

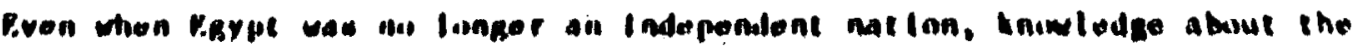

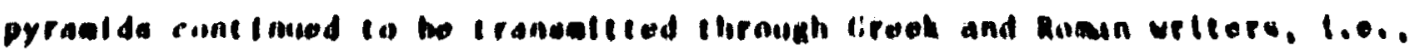
through diffecont culturou. Mis throad continued into the modleval perlind with the Arab hiecortan, and continues with the wath In Peyptolugr whteh is buting anno inday.

$$
80018 \quad 1044
$$


A second point to make is tive importance of conterporary writteis records. It is only by such records that we know who bullt these structures ind why

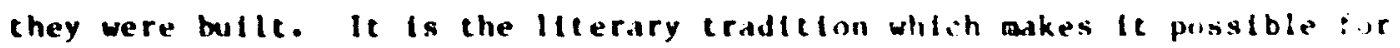
this Information to be translated into wore conteaporary language.

The contents of the pyraelds have not survived because they were linted for their intringlc value. Most of the building stones, however, have realined. Some of these were rewoved, partially because the pyramids dre located close to a large population center and t was easter to remove the stones than to quarry new ones, but the ajortity of the stones vere not resoved. So a third point to ake is that stone ay be a sultable wediu.a for reposttory arkers ince it is generally not valuable in and of itself. If scone is used in the arters, the pleces should be of sultable slice and shape to elniafze the liklihood of belng reused in later bulldings.

A final point to ake is the need for redundancy In the arker syater design. The number of stones used in the pytanids is so labense that in Intent Ional attempt to diseantle the seallest one (I.e.. Wenture's) was overchelned by the expense of the profect. (II)

\subsection{2 stonehenge, Encland}

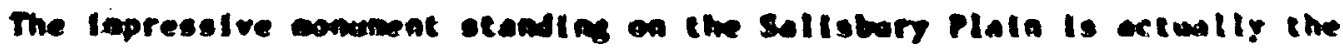

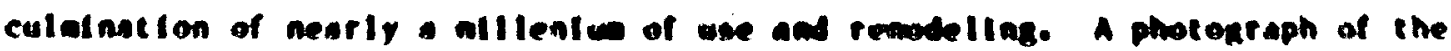

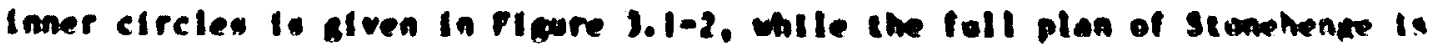

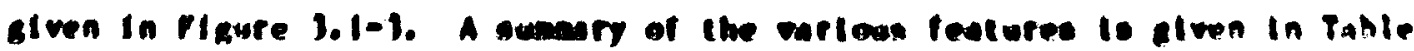

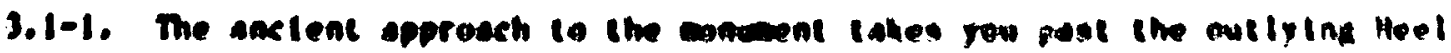

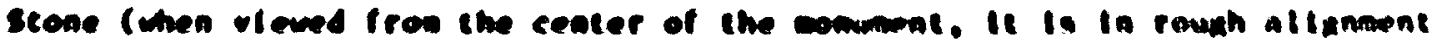

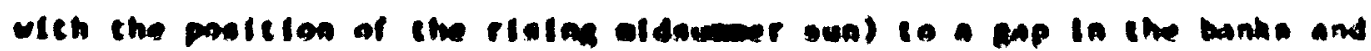

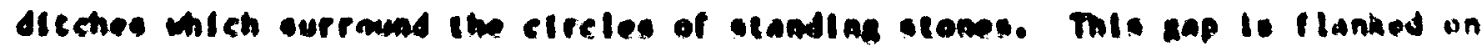

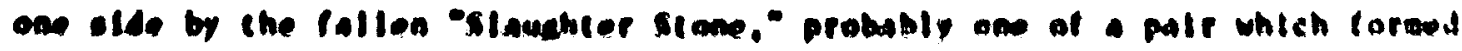

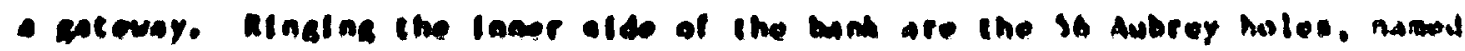

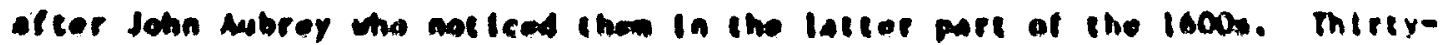

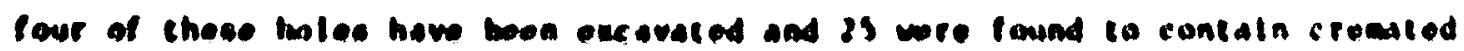

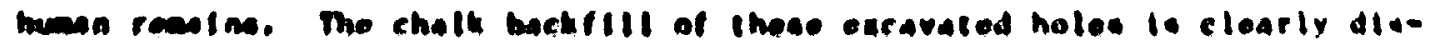

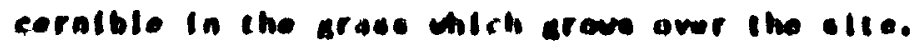




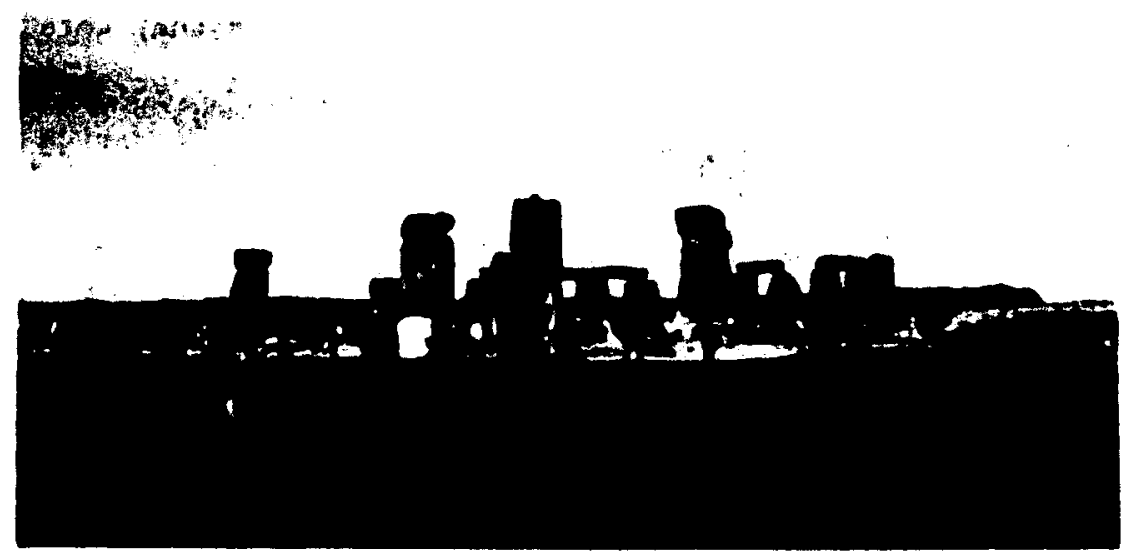

Figure 3.1-2 Inmer Citcles is Sivolienge, England

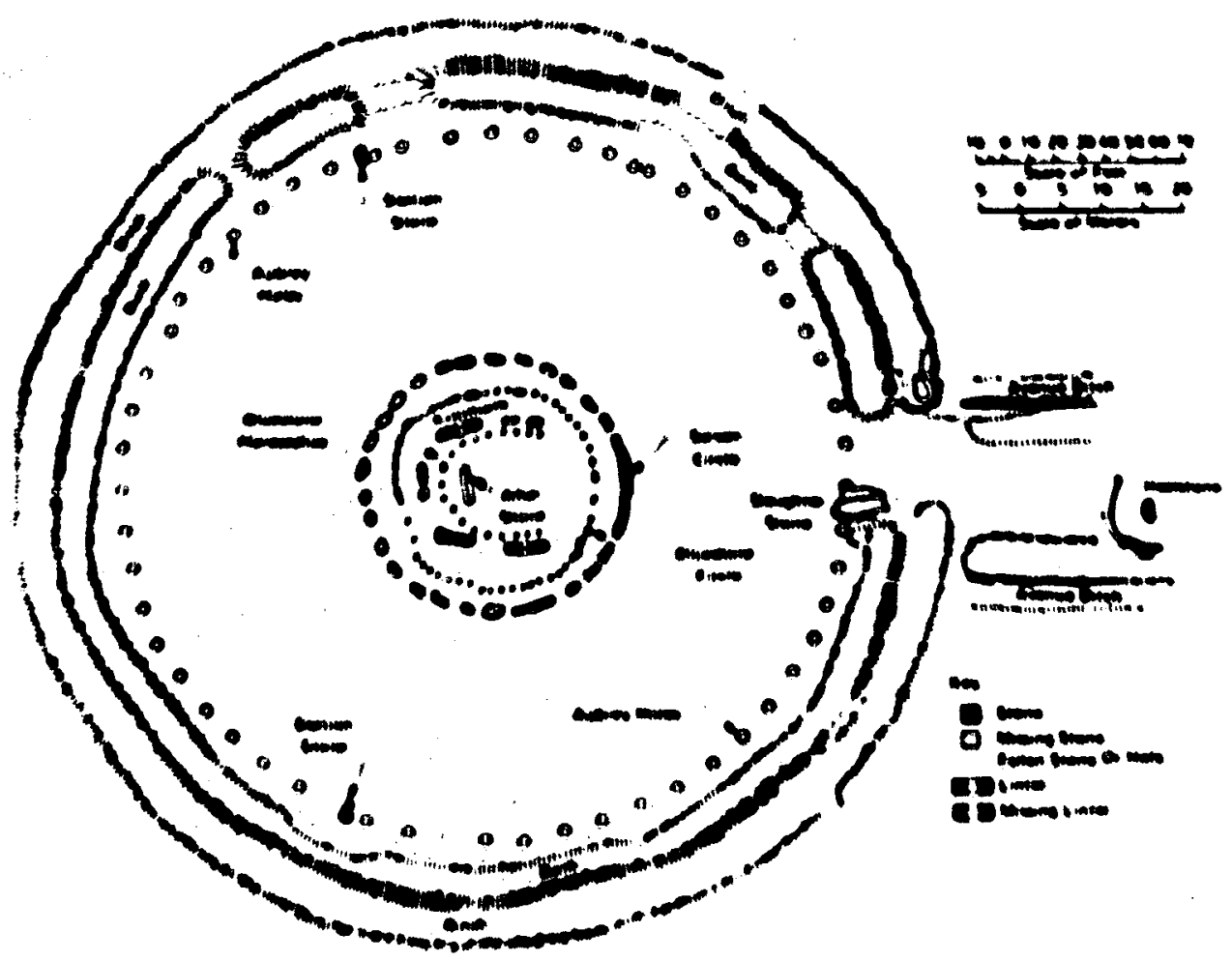

Elgure 1,1-3 Plan of sionehence lingland 


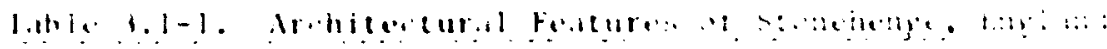

\begin{tabular}{|c|c|c|c|c|c|c|}
\hline Feature & $\begin{array}{l}\text { Approvionule } \\
\text { Demoneter ifll }\end{array}$ & Materiah & Cumposents & Drunemensm & $\begin{array}{l}\text { Budding } \\
\text { Phase }\end{array}$ & $\begin{array}{l}\text { Irutik } \\
\text { Tode? }\end{array}$ \\
\hline Buter Band & :w1 & Chaik & & 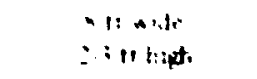 & 1 & $1 \therefore$ \\
\hline Imath & $\because 41$ & & & 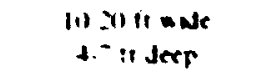 & $\mathbf{I}$ & lis \\
\hline Innei Bunh & $\because \because$ & Choit & & $\begin{array}{l}\therefore \text { If wali } \\
\text { or heph }\end{array}$ & 1 & li. \\
\hline Rime & :N1 & Chalk folled & $\begin{array}{l}\text { on futren } \\
\text { Invise }\end{array}$ & 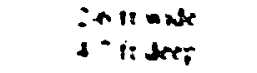 & 1 & le. \\
\hline Salnon Silmon & & Sar een & + & 4. a it latst & $\mathbf{I}$ & $\therefore$ Murnet \\
\hline Itexl Sling & & Syren & 1 & 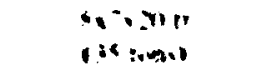 & I & li: \\
\hline Mmp & l'n" & Surwen & 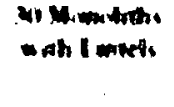 & 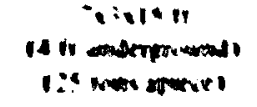 & III & 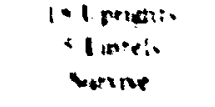 \\
\hline Rine & $\because 4$ & Bluctonent & 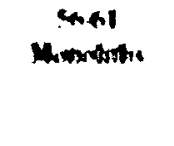 & 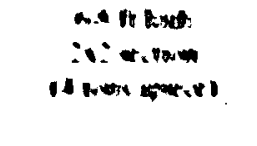 & III & 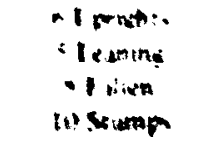 \\
\hline Iher wathise & & Smaten & Iranthoun & 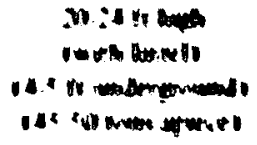 & III & 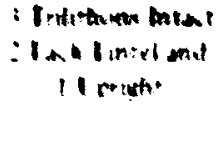 \\
\hline Itor worture & & Murwastix & 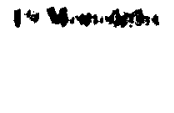 & 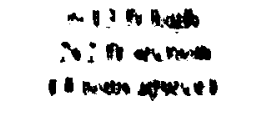 & aI & - Muner \\
\hline Shoupher Mome & & seram & 1 & 1.910 & in & Inen \\
\hline NAw Manew & & $\begin{array}{l}\text { Pole lotrow } \\
\text { sondetimer }\end{array}$ & 1 & $11: \sin \cos \theta$ & III & 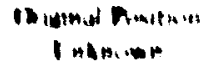 \\
\hline
\end{tabular}

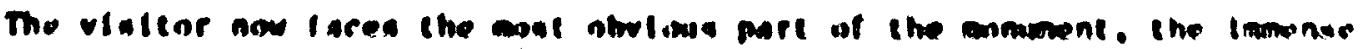

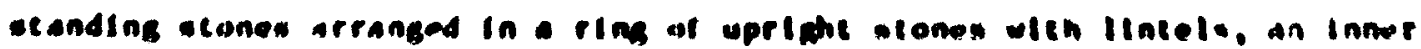

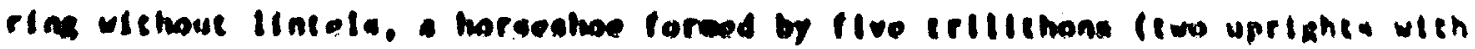

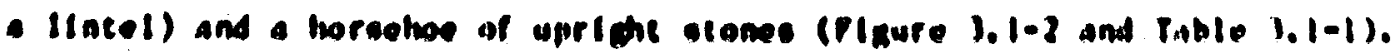

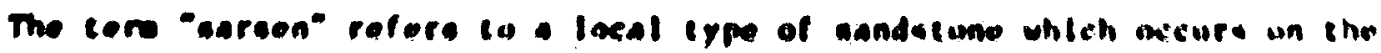

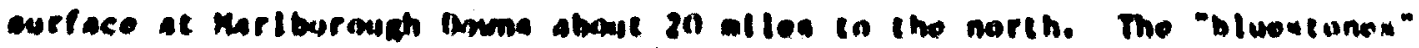

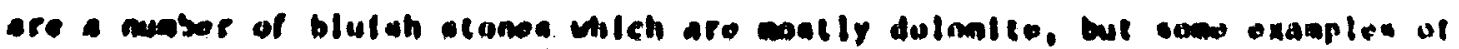
royolite. andetone, valcante and ealcareoug ash dre included. The blwevtunes anly oceur cogether in a sall area (about one alle squaro) in the Prodiclly reuntalina of Valoe, som 200 allen froe Btanohenge. (20-22)

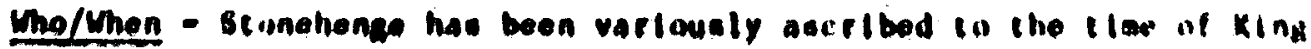

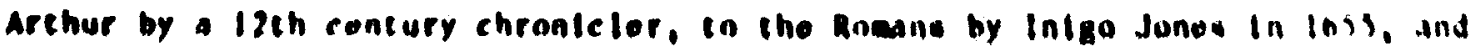

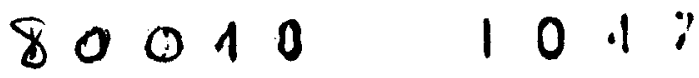


to the Drulds In 1740.(22) Around 1900, the suggestion that Brunze Age Britalins hullt Stonehenge was put forth, and that is the theory now decepied by most historlans.

The quext ton of who bullt stonehenge was settled long before the gillestion of wen it was billt. The re-callbration of carbun-1: dates has creited a revolution in European prehistory, (23) and places Stonehenge as a conteaporary of the pyramids of Egypt. Building at Stonehenge began C. 27iti-25iti B.C., and the firat milling phase Included the ditch and hanks, the dubury holes, and the Herl Stone. It also way have Inclided the station stones.

The min change In billding Mase Il was the cransport and erection of the Iaported bluestones in two concentric circles. This tonok place c. 2livo B.C. but was never fintshed. Instead, the bluestones were rewoved and the circle and horsenhoe of sarsen stones were ralsed (Phase IIIA). Finally, the bluestones also were arranged in a horseshoe and cifcle (Phase litb). The latter work was done c. $2100-1900$ B.C. $(20.23)$

Why - The alignment of the Heel stone with the aldsumer suntise was first noted by stuckeley in 1740. However. It was not ont Il the I9wis that further astronontcal uses of the momument were hpothested and tested: this was the work of Hawkins.(22,24,23) This work drew great protest, particur Larly froo Atkinmon, the excavator of the otte, $(20,26,27)$ but It is now generally accepted that the iflitthona were wed in followita the antions of the wun and mon. How any other allgnments are olgatfleant and wether or not the Aubrey holes conatltute "computer" for calculatios ecllpaes is ot III - encer of debale. $(2), 26-11)$

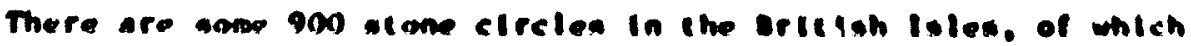
scomehenge ia only ane. It hos. however, neveral walgas teatureal the

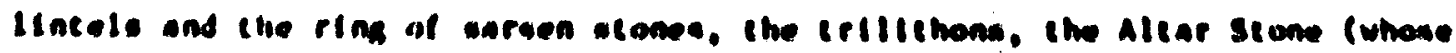

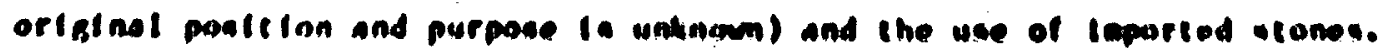

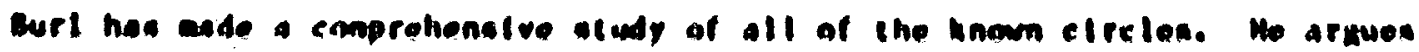

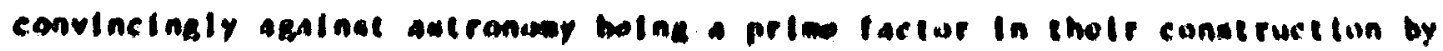

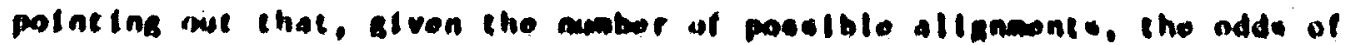

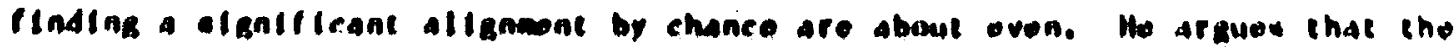
ascrongetrat function of the ring was only part of lis purpuse an a ritual

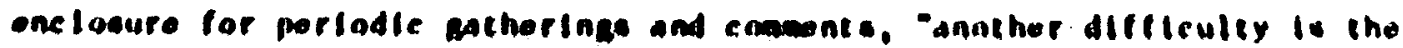
entire absence of witten recorde that could confiri the aetronoalcal

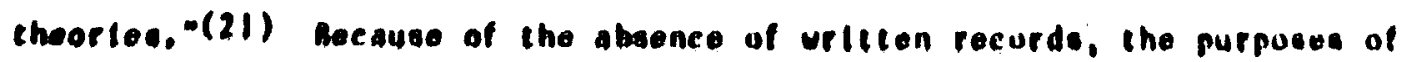
these exne ringe aclll aro belng debated. 
State of Preservation - Stomehenge is visleed by over throe-guactery of i atlion people per year, and ropes now protect the bank and ditch from obliteration. (21) The nomume, however, has survived while Britais his undergone invasions (In SS B.C., 48 A.D., and linh A.D.), the iniernerine wirs of the Roses (1455-1485 A.D.), and the two World wars. By the Ixits, with the rlge of Romanticlsm, the monument was auch visited, and hamers were rented to tourista for the purpose of chipping of weantoes. (22) Monoliths, however. are not easily dewollshed. As way be seen from Table 3.1-1 and Flgures 3.1-2 and 3.1-3, about one-half to two-third of the uprighi stones survive and remain in position. Several of the stones had figures carred upon thed in the Bronze Age, and these way be seen today.

other Markers of the sabe Cente - As ment toned above, stonehenge is but one of any stone circles. Durl has copplled data on some 963 stune clrcles wich occur In the British Inles. Ireland, and mritcany and this discusston leans heavily on hit work. (21) rwothirds of these circles are preserved well enough in eat inate their aliabeter: these range froe under 9 ft to over $200 \mathrm{ft}$ with over half of the examles falling between 10 and 6 ) ft. The stie of Avebury contalno a ditch nearly onequarter of a olle in diacter (IIno ft) and ranging from 23 to 33 fe in epth. Walf the tam of avebury lles within 1t. The large megalithte ring inglde the ditch is the iarges in ine orition Istes with a diacecer of 343 ti.

Huch effort has theen expended in cosuring and reporeting the punition of

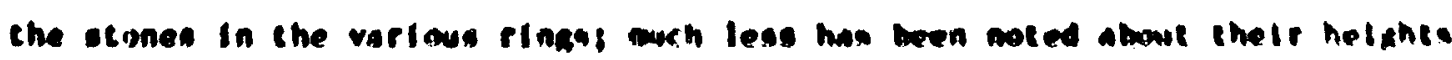

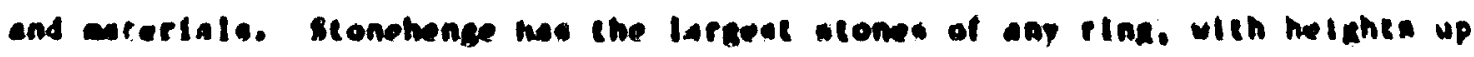

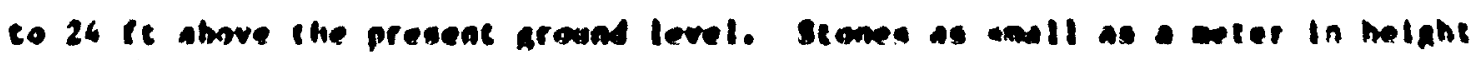

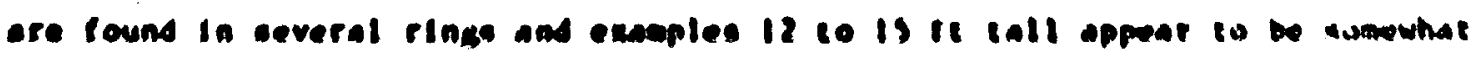

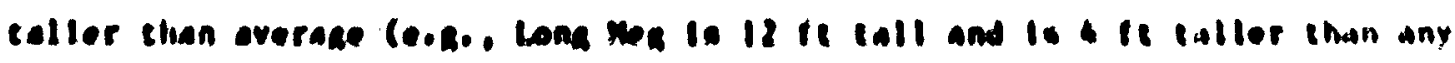

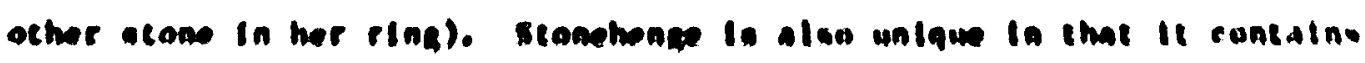

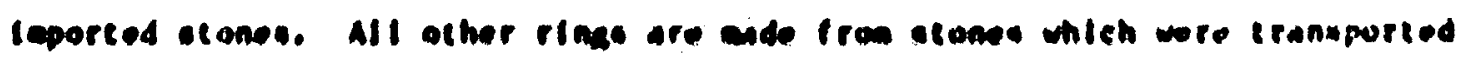

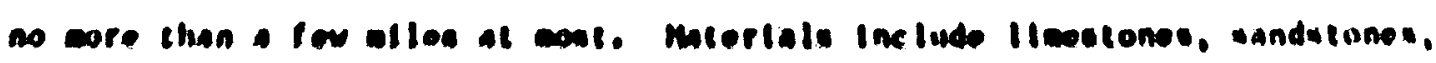

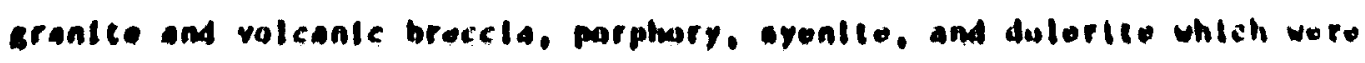

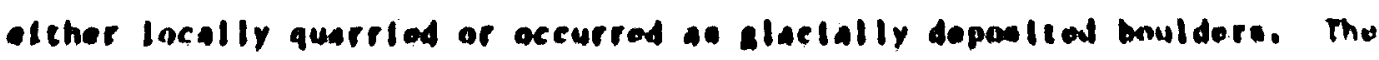

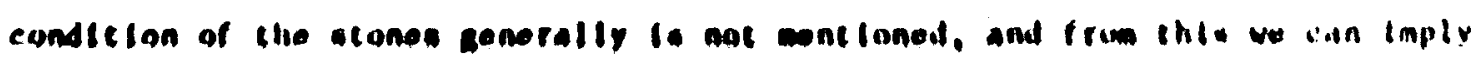

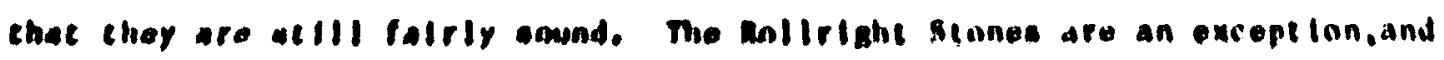

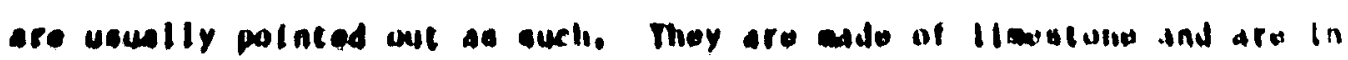
cragentary condte lon, (21) 
History - Stonehenge, per se, has been written about since the $12 \mathrm{th}$ century A.D., and has become well-enough ensconced in public knowledge to appear In many literary works Including those by Wordsworth and Hardy. (22) An earller reference (lst century B.C.) occur in Dlodorus siculus (History, Book $V$ ), but no nase is given and the attribution of this passage in Stonehenge is therefore debatable. (20) It is Interesting to note that Geoffry of Monmouth (c. 1136) tells of Merlin saylng "send for the Glant's Ring In Ireland", when the stones actually originated in wales. The quarry stte may lle on the trade coute from that patt of England to Ireland, but the oral tradition, though rewerbering that the stones were lapotied, has the wrong place of origin. Ceoffrey also relates that the monument was erected (by Merlin at King Arthur's request) for coomemorating some slain nobles, but says nothing about its astronoalcal purpose. $(20,32)$

The monument cont Inued to be know as "speclal place". Chough the exact nature of the place $1 \mathrm{~s}$ st11l dehated. Mis debate extends to the other stone rligs as well. The special mature of these rings and the Influence they had upon the local population was a eatter of great concern to the early Chrlstian church. The edicts of Arles ( 432 A.D.), Tours ( 36$)$ A.0.), Kantes (658 A.D.) and Toledo (6s) A.D.) exthore the local blshops and clergy in destroy "imase stones mich in reapte and mody places are stIII worohloped and where ravs are st111 eade".(33) The destruction or toppling of stemes seen in tive ringe ay be the regult of these edicts and Inter attents to wipe out the Influance of these papan omments.

Many of the pings nurvived these attachs. They asy have done so because

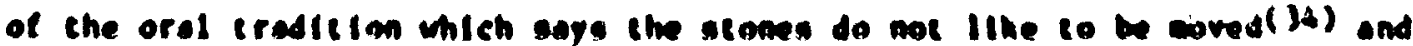

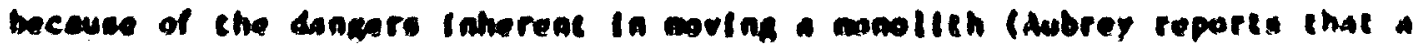

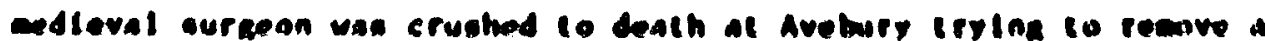

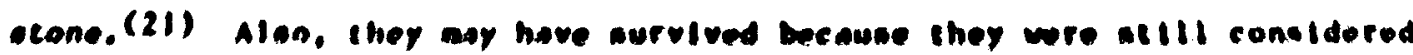

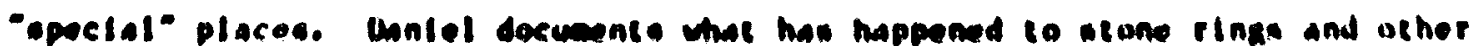

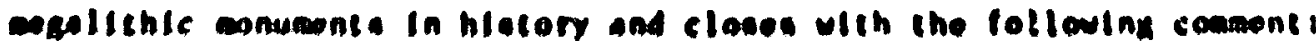

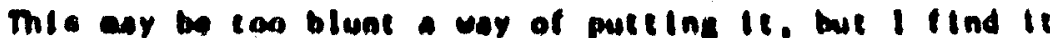
difflecule to envionge thy there should be a chrloflan

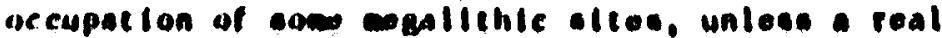
cradiction of thele taportance as opeclal and sacred placen was carrted througli the purlud of the arunae Age and parly Iron of burburlan Rurupe and into hlofurle (100., (3) 
Relevance - Stonehenge is a prime example of the difficulties enimutered In marking a site with only level I Information. It must be enphasized thi: the purpose of Stonehenge and the other stone rings is stlll beling debated because of the entire absence of written records that could confirm the astronowical theories". (21) it is this absence of britten records which nut only obscured the purpose of stonehenge, bit even the tiaes when the varfous parts of it were constructed. That Stonehenge Is a conteaporary of the Egyptlan pyraalds was known only after the Introduction of carbon-l: dating.

The history of Stonehenge points out the mossible corruption in Information conveyed by oral tradition. Though the wedleval chronicle recurds the tradition that the stones are inported, ti has the wrong place of origin.

The plan of stonehenge and of the stone riags in general aus be very useful for a reposttory arting systeo design. The use of aultiple components means that the plan of the area can be reconstructed even though snav of the component, have been lost. Stomehenge has lost approximately one-third of its stones, yet there ts no debate about Its plan. For the nther ings, with mach saller component, sone hon stlll survive well enmigh to eatlante thetr diameters. It appearn that redundancy in the muber of cmapments used to

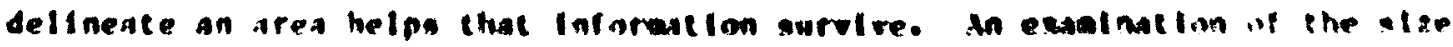

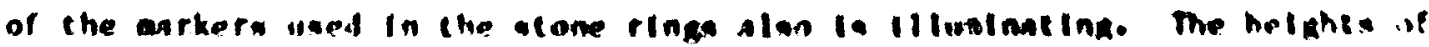

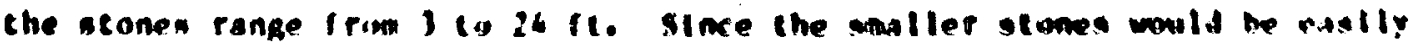
reapved, It appeara that they have pen protected by remote lomatlone and ural

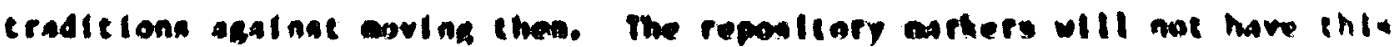
"epectal nature" accributed la them. and so they ought to iall in the wpper

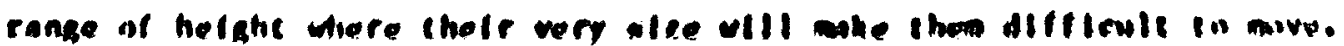

\section{1 .3 Hace Linoe, Pera}

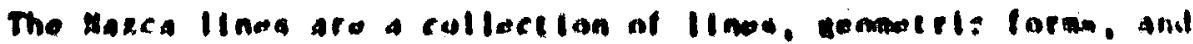

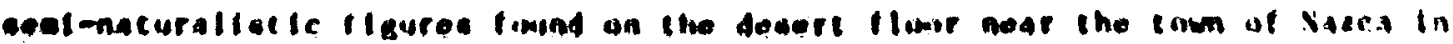
southern Poru. They have been the cause of eich epeculation for two rodsund

- They are auch mire vialble from the alf than an the around.

- They are draun on an enormuse sede. For unanglo. one lardo cleared tpapezold eoseures 2400 a 130 fel a large fleure may maseure 500 It In lengefig and elngle lino ay run arro than b.s allew in langen, (35) 
The lines (actually paths about 2 ft wide) are made possible by a set if geological circumstances. Wind erosion across the desert toor carried ots the dusty surface soll, leaving behind a "pavement" of pebbles and boulders. over tiwe these stones develop what 18 known as "desert varnish," a brownish-black coating of iron and wanganese oxides formed by the in situ decomposition ot rock and the deposition of oxides upon the surfaces by cap1llaty action. The rate of tomation of this varnish is very slow, and may have begun as far back as the pleistocene period. The underlying soll. however, rewalned pale in color. Plcking up a stone will expose the 11ght-colored soll underneath it. Plcking up row of stones will create a light-colored line. (35)

Who/when - The answers to the quesctons of wo drew the lines on this aatural blackboatd, as well as when and wy they were dram are not definitely known. The figures dram on the desert lloot (eonkey. Ilatd, oplder, trophybearing killer hale, etc.) find parallels in nace wares, a distinctive type of pottery wich dates from about 200 B.C. to 600 A.0. The elellarity led to the conclusion that the sabe population was reponolble for both creations. In addition, 85 percent of the poteherds collected on the decert floot by

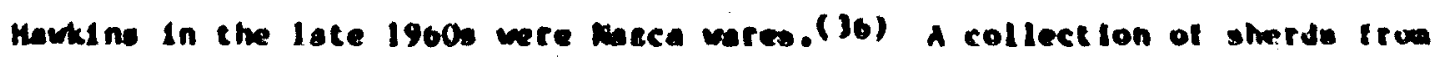
the periphery of the desert proved to contaln only incce weres. (in) Amulher eype of evidence is the carbon-14 date obelned from a pot which wa set at che Intereection of 160 lines, and geve dato of siv A.0. Iso

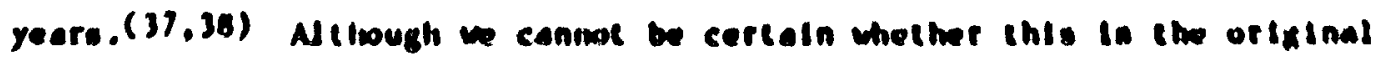
stake (or a loter replacement). Che date talls within the mace pertod. iw Imer chronolowy of the Itmen has ben developed and. Alven the abwonce of

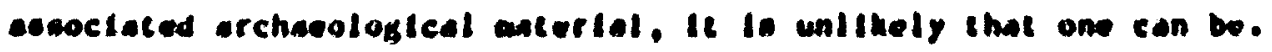

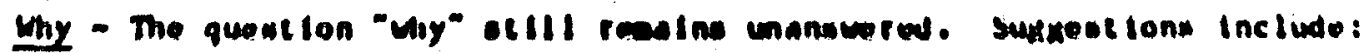

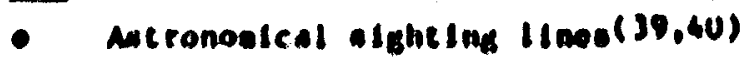

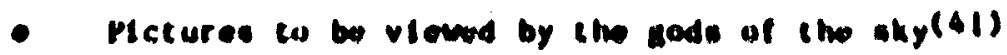

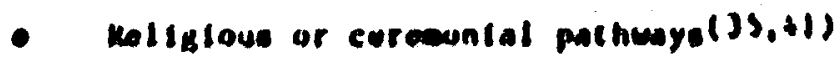

- Mechaniso to bulance the rosiourcos and population.(36)

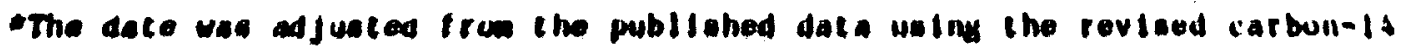
half-lite of $573 u$ yeurs and the Mach recaltbration curve. 
One of these suggestlons cin be allminated. liawklns tested the hypothesls of astronomical sighting lines by accurately surveylng them and usinp, a computer to check the allgnments as he did with Stonehenge. The llnes cinnot bre used physlcally to slght stars, and 80 percent of the lines lick any semblaice l: solar or lunar allgnment. (35) As for the remalning suggestions, there is insuffictent evidence to elther conftrm or deny any of them and sol the lines remain a mystery. $(42,43)$

State of Preservation - The lines were made posstble by a particular set of circumstances. They were preserved, In part, hecause of a very low liscal erosion rate. They have also been preserved because of their reacte location (the area Is too arld to support a peranent population), and the fact that the area was depopulated shortly after the Spantsh conquest. The IInes are a fraglle phenowenon and undergo rapld degradation when people drive or walk over then in order to see thew. A photographic essay by NcIntyre( $\$$ t) Includes a photograph which shows the destruction undergone by one figure in only twelve years.

Other Markers of the Sabe Cenre - Anclent artings of thls sort occur In numerous places other than Nacca. Peru. Howking (35) estinates that there asy have been 50-100 such oftes In Peru alone. Horrison wenctons stces in Chile and Blivia.(41) over fifty droulnge formed by the sace technique occur In Californta and Arizone, (45) though the ages of these figures are not known. As with the Macca acertal, wost of these reming appear to have survived because of chetr reoote lacation and sultable cliatif conditiuns.

Hetory - The figures were brought $t a$ the atiention of the Reneral world Ia the late 1960, by kosok, though they were hnown betore on local Ieve1. (18)

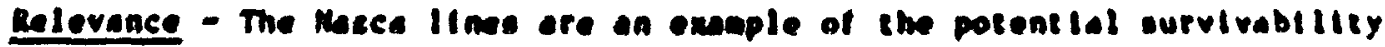

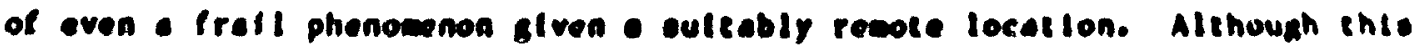
effect cennot be quantifted. the reposteory vill also bo lucated in an area

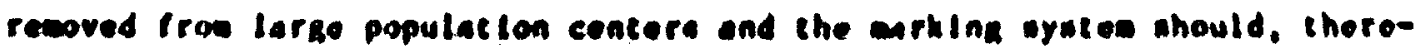
fore, hove alallar increase ta curvivabllity.

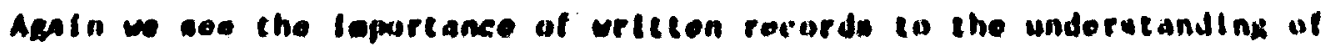
anctent arkera. The purpane of the thace lines is uncertain and thore ta a

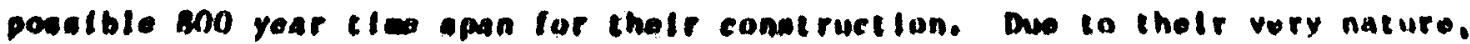
ic Is unllkely that oven a relative chronoloay can bo bulle for tho conseruc-

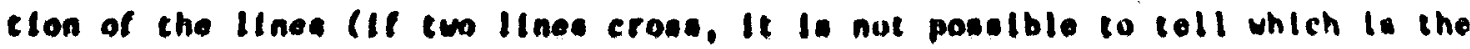


earlier). This lack of knowledge is due, In a large part, to the absence of contemporary written information about the culture which made the lines.

Pinally, although these lines are clearly visible frow the alr, they are difficult to track on the ground. In contrast, a repository marking system should primarily stress ground vistbllity.

\section{1 .4 Serpent Mound, Ohio}

The Serpent Mound 18 an eabankment of earth in the forc of a serpent in the act of uncolling (FIgure 3.1-4). In its present state of restoration, the Setpent consists of two parts, the serpent proper and the oval shape. The later has diageters of 125 and $60 \mathrm{ft}$ and is th high. A sall aound of burned stones lies in the center of the oval. The length of the serpent proper is $1254 \mathrm{ft}$. The colls and convolutions, however. fit within an arc that $18737 \mathrm{ft}$ long. The average width of the body 1 s 20 ft. The helght is

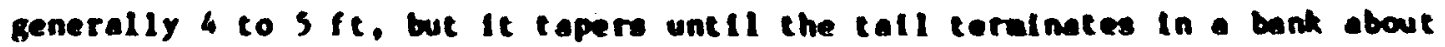
I fe high and 2 ft wide.

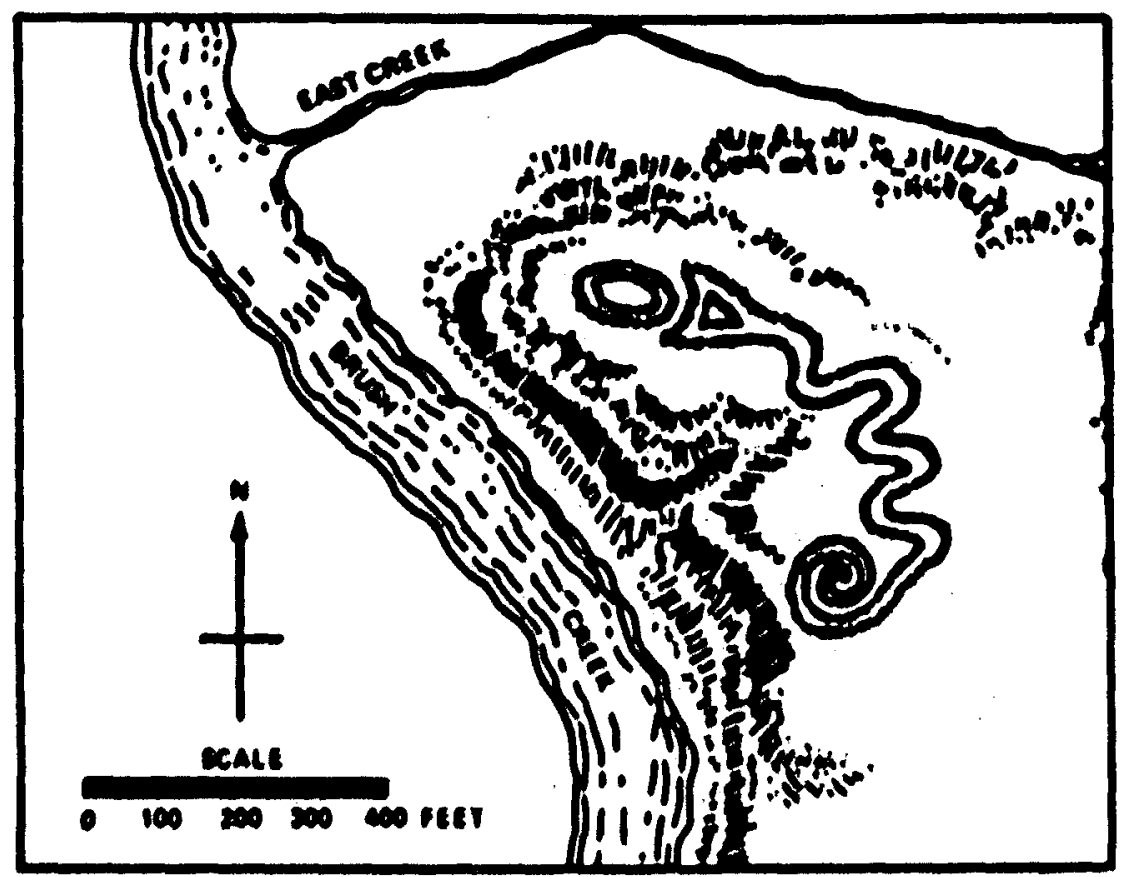

PIgure 3,1-4 Serpent Mound

$8 \cap 14010 \% 4$


The serpent was formed by blocking out the patern with stones ind ity. On top of the stone cure a font thlck layer of clay was added. Abrve thls lles a 2 ft layer of dark soll. (46)

Who/when - iw drtifacts were found In the excavition of this ponuarenc. There is, however, a burlal sound withia 400 ft of the serpent. The artifacts found in this mound belong to the Adena Indians who lived In ohio between lino B.C. and 700 A.D. It Is generally accepted that the mirial wound ind the Serpent Mound were bullt by the sane people. $(6,+6)$

Why - The purpose of the wound is still not known. Stixe it is obvijusly In the form of a serpent, wost interptetations use the role that ireature played in indin mythologles and religions as basls for their hyputheses.

It should be noted that there are several Interpretaclons of the figure. These differences are due to differences in Interpretim irregular features on the ground. The form of the serment and the oval shape hove been quite clear. and these are Identically shom in all the drwolags. It is the features beyond the oval and to the gldes of the meck wich are in dispute. The earlifat

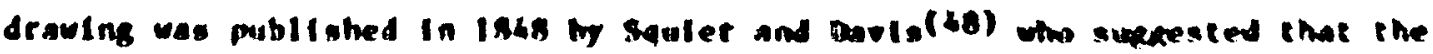

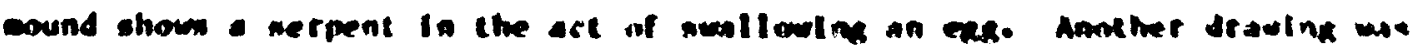

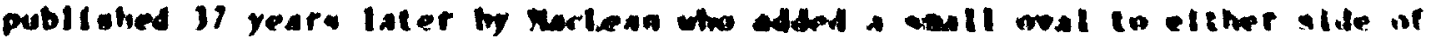

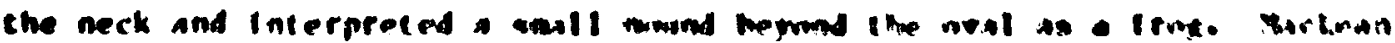

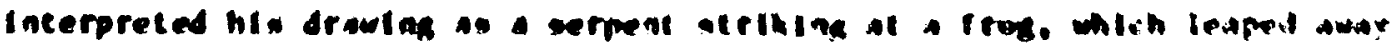

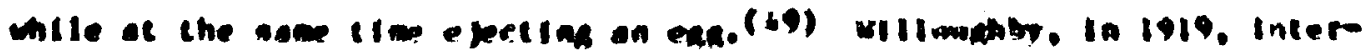

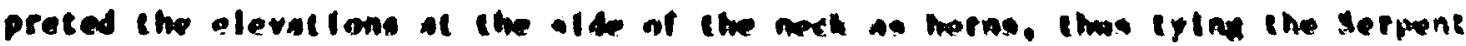

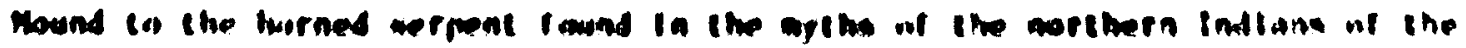

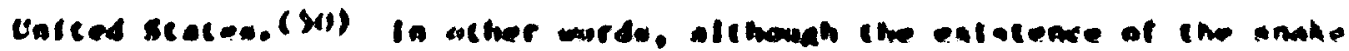

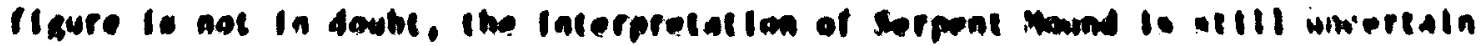
and somether notullowe.

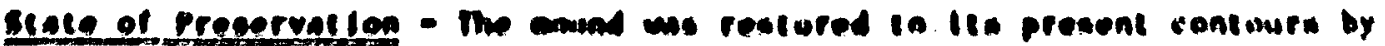

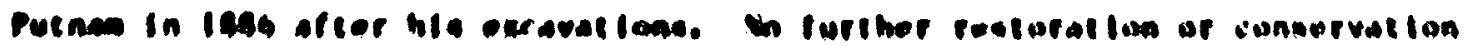

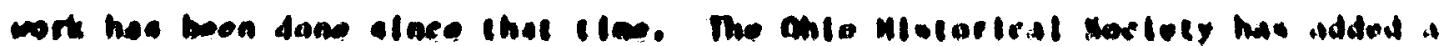

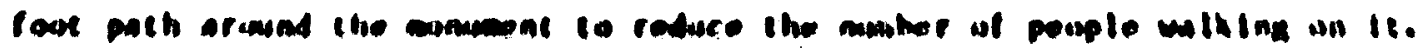

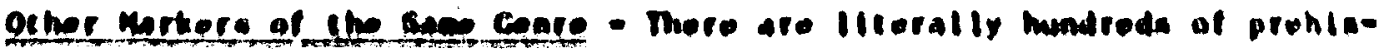

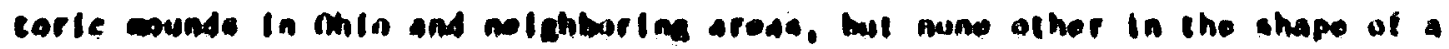

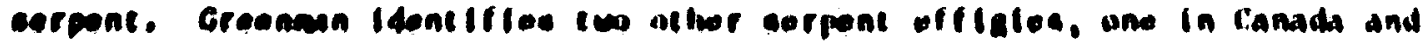

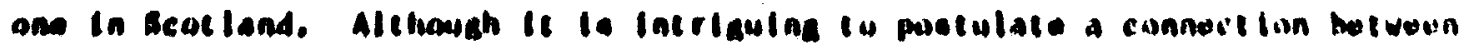

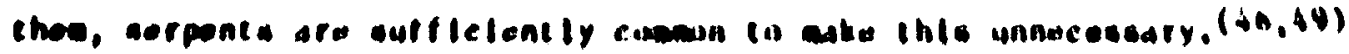

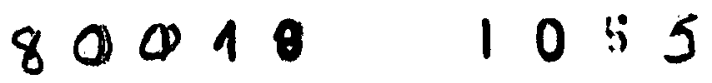


The serpent was formed by block ing alt tibe patcern with simes and illy. On top of the stone cure a foot thlik layer ot clay was added. Ahuve thls lies a $2 \mathrm{ft}$ layer of dark soll. (46)

Who/when - is artifacts were found in the excivit lon of thls monument. There 1s, however, a burial mound withla 400 ti of the serpent. The irtifacts found In this mound belong to the Adena Indtans who lived in ohlo between lini)( B.C. and 700 A.D. It is generally accepted that the burlal mound ind the Serpent Mound were bullt by the sabe people. $(46, i 7)$

Why - The purpose of the mound is still not knuwn. Since it is obviousIy in the form of a serpent, most interpretations use the role that creacure played in Indian mythologies and religlons as a basts for their hypotheses.

It should be noted that there are several Interpretations of the figure. These differences are due to differences in interpreting irrequior features on the ground. The form of the serment and the oval shape have been quifer ilear. and these are Ident lcally shown in all the drawinga. It Is the features beyond the oval and to the ides of the neck which are in dispute. The earllist drawing was published in 1848 hy Squiter and Davis(48) who supkested that the aound shows a serpent in the act of swallowlng an ekg. Another draulink wis

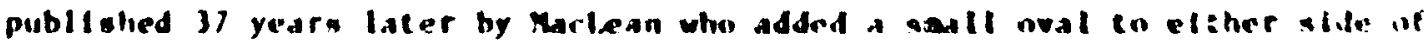

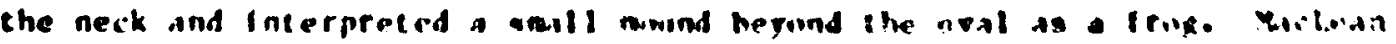

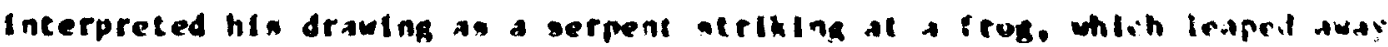

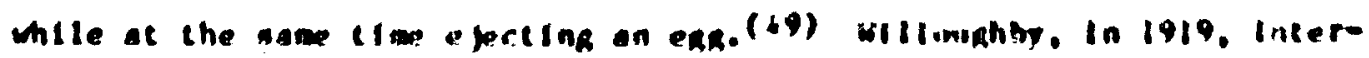
preted the elevations at the olde of the neck as horns. thws tylnk the serpent

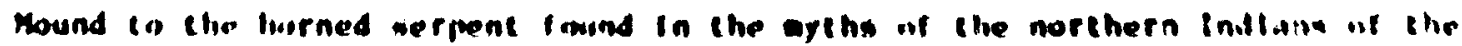

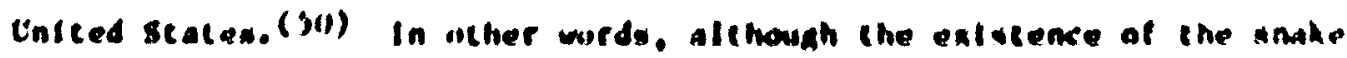

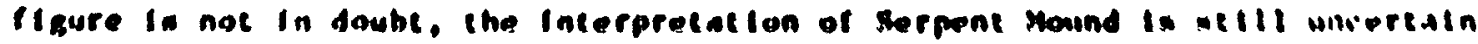
and wow what notulims.

seace of Precervation - The mund wa restured in ita present consuwra by

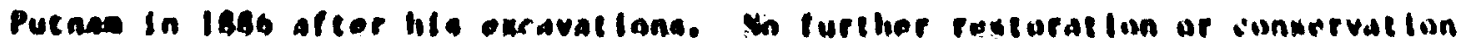

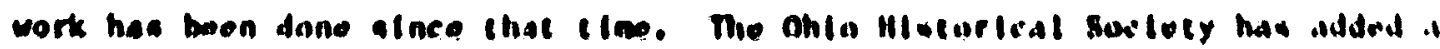

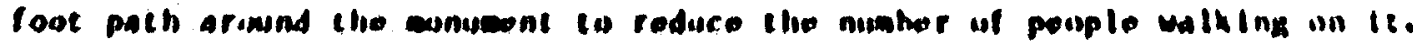

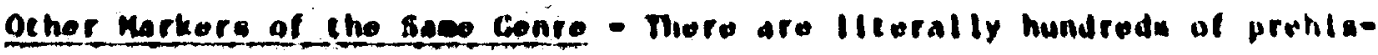

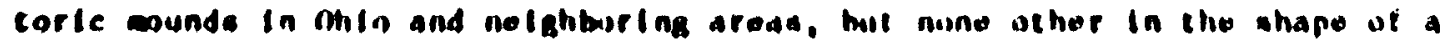

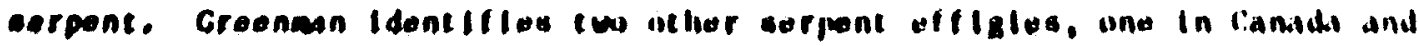
one In scotland. Although tt is Intriguling tu postulata a connectlon hotwoun

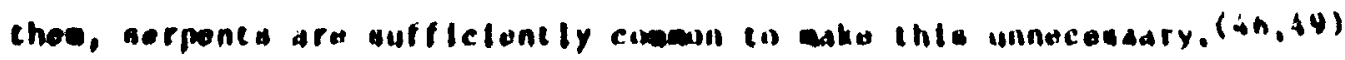


discussed by Travlos(SI) and the other references cited thereln. A general photograph of the Acropolis 18 given in figure 3.1-5, whlle a plan of the monuments discussed hete is shown in Figure 3.1-6.

Beule Gate - As you approach the Acropolis, the first ceremonial entrance you reach is the Beule wate. An inscription on the monument cells us that it was paid for by F. Septinus Marcellinus and bullt C. 280 A.U. The two pylons are plerced by a gate wich is aligned with the central opening of the Propylais. It is bullt of lifestone and the blocks were taken tron an earlier comment wich dates to c. 310 B.C.(52)

Agrippe mouvent - The Agrfppa wonument stands on a nacural cerrace between the beule Gate and the Propylala. The slab for the statue stands 29 ft high, was ade of arble, and or IgInally bore a fout-botee charlot. Invcriptlong on the olab tell us that the latest statce weo talend to karcue Agrippe In 27 B.C., wile the original group wa dedicated to celebrate a charlot victory by the city of Pergewn in the Panathenalc Cades in c. 178 B.C. We know from the witings of Pluterch and Dio Cassius, thet the slab once bore statues of Aathony and Cleopatra, but these blew dom in 31 B.C. (32)

propylale - The propylala is the cleselcal geteway to the Actopolis. and 1. part of the overall comuentel rebullding of the olte undertalen by

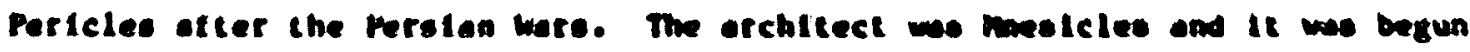
Ia 437 B.C. after the construction of the porthenon. Wort halted in 4): B.C. with the advent of the reloponnestan war and we never reerned. The tate is

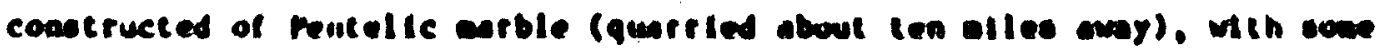

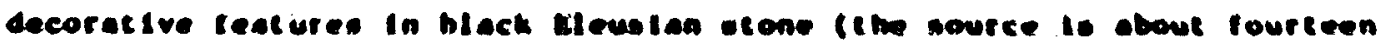

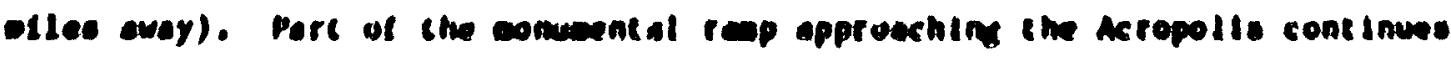
chrough the center ot the bullding. The rap it Ilanked on both bides by a row of colume and two pates. The wilding wins on the porth and couth also

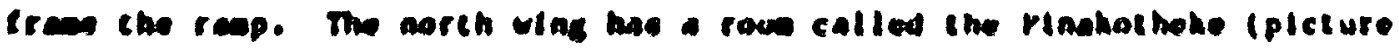

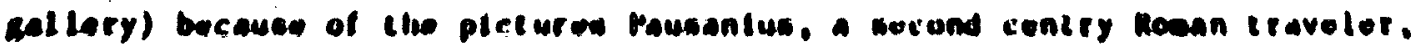

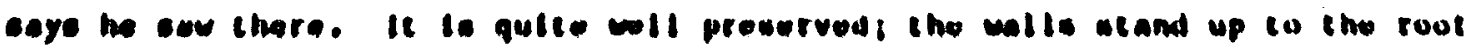
leval and eclll war archlectural foolwron. $(31,32)$

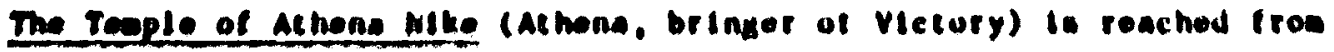

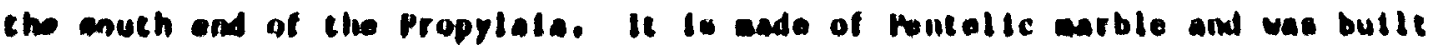
In 427-426 B.C. to celebrate the pace villi rotula. The architect was

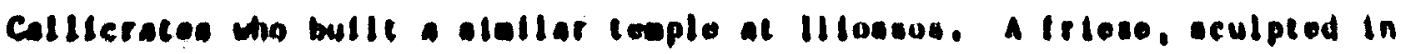
hith relief. ran around the outertor of the butldiagl fout of the fourteen

$80040 \quad 1057$




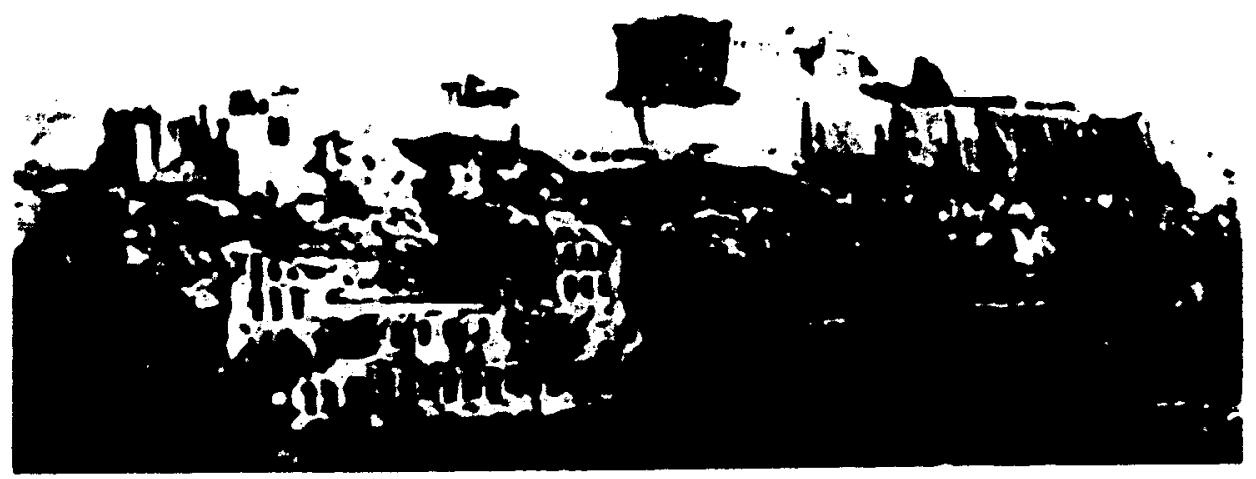

Pigure 3.1-3 ihe Acropolis, Creece

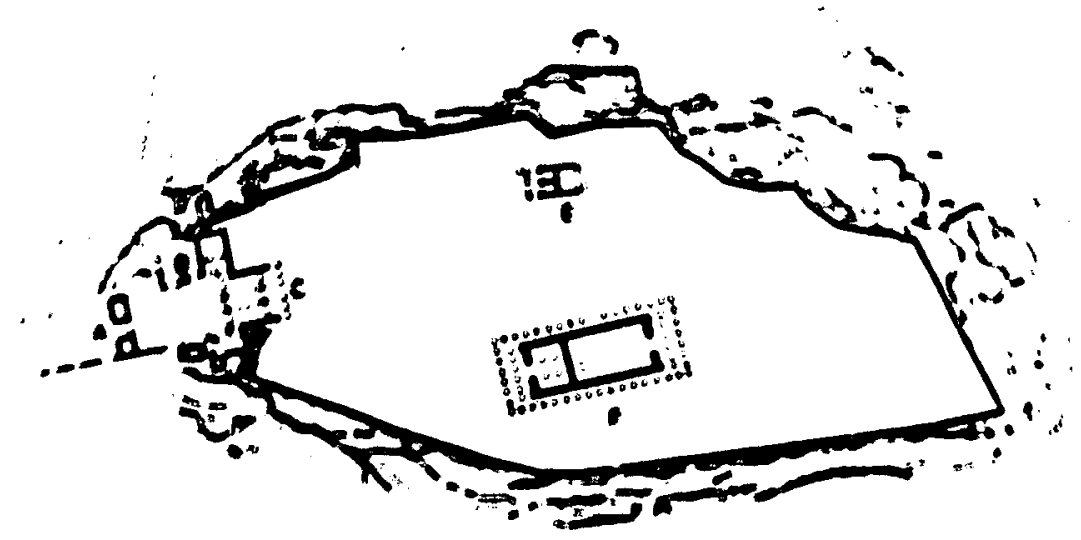

Ex
Ar Doule cale
Di Tomple of Almos Mille
Bi Alefippo Honumat
bi tirechimeion
ci Propylaia
Pi Partheasa

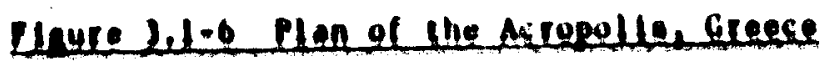
80010
1058 
slabs are now la the British Yisemp. The tenible is also known as the temple of "Hingless viciory". a cradition recorded by Pausantus. (52)

The trechthelon is an intrigulng edifice, bullt on more than one level and want to house several cults, Including those of Athena, Poseldon and the founding rulers of Athens. It also housed in anilent and venerated statue of Athena. The building was part of Perlcles pian for the rebullding of the Acropol1s. It was begun In 421 B.C. Interrupted by the Peloponneslan War, and conpleted in 409 B.C. With the exception of dark cleustan stone used as the background for the frieze, the bullding was constructed of Pentelic arble. The extertor walls and porches are quite well preserved (up to the roof). Differences of opinion exist about the plan of the Interlor, which has undergone extensive renodeilng in the course of tiee. The southern purch is known as the Porch of the Waldens (or the Porch of the Caryatids). Instead of six coliwens, there are $1 x$ statwes of young aidens In Ionk tunlcs which aupport the rimf. One of thene was taken bact to England (along with any other arbie lteas) by Lord Figin. The lloor of this porch has disappared. but the celling is nearly intact.

The Parchenon or ceaple of Athema Parthemas (virgln Athena) ocruples the highent part of the Acropolin. It was eant to be an artistic materplece and to serve as the atate creasury but wot to replace the frechtheton in renerablicy. Forwing the carainal leature of pericles plan, It wa witi in 467-438 b.C., and the best and woot celebrated sculpters in atrens were eng-

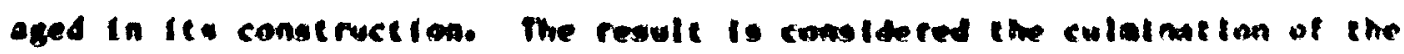

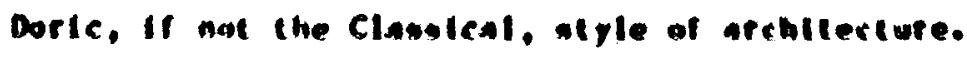

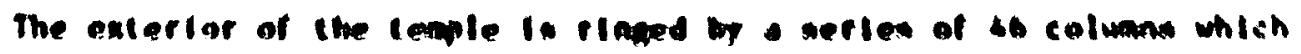

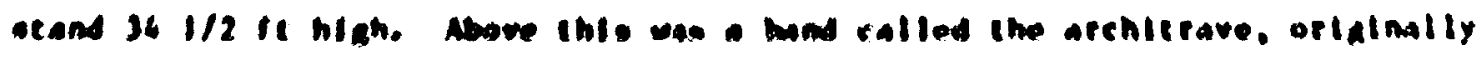

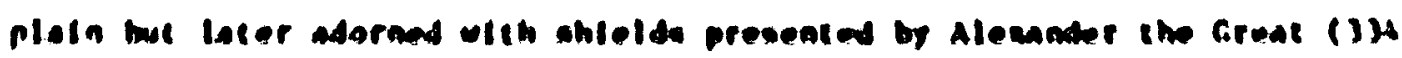

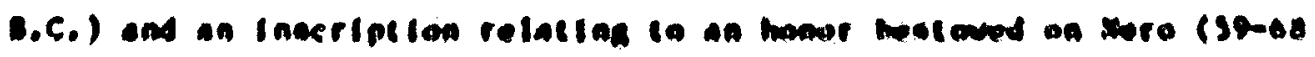

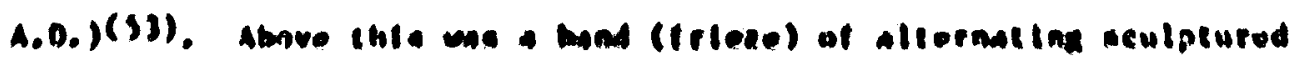

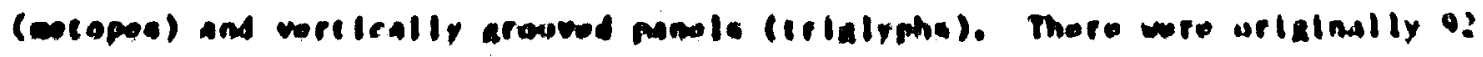

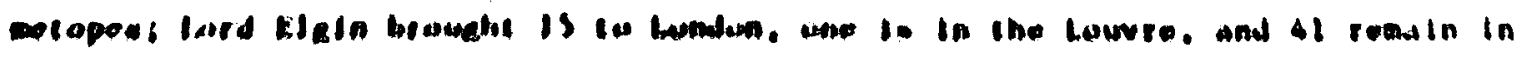

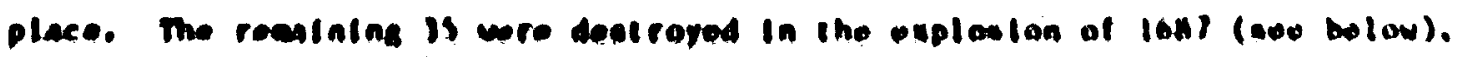

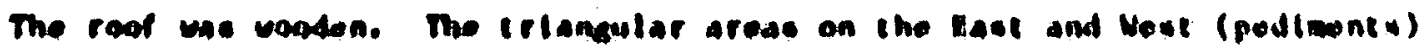

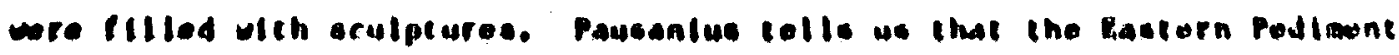
ahowed the birill of dehend ts wa largely destroyod by the bullding of 4

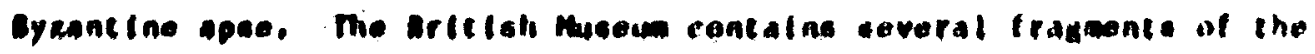


reasining sculptures. The Hestern pediment showed the contest of dihena and Poseldon; this group was destroyed when the sculpture fell during reooval in 1687.

Around the outer walls of the bullding ran a continuous frleze of sculpture. Its original length was about 525 ft; 176 of wich exist in Athens wile $247 \mathrm{ft}$ are in the British Museur. The resainder was destroyed in the exploston of 1687. The entire friese was dedicated to showing the processton of celebrants in the Great Panathenaean Pestival honoting Athena and is known for 1 ts masterful sculptures. (54)

It should be noted that nowe of chese bulldings have any wortar. The stones were closely fitced by careful dreasing. and where extra strength was needed, the ancient Creeks used soall bolts and clacps of Iron. These were rendered nearly rustproof by coating then with lead. An we ohall see. atslar precaut ions were not taken at the turn of this centry when restoration work was done on the Acropolls, and the ecthode used have actualiy accelerated its deterioration. $(31,35)$

Who/hhen - Pericles was the prine nover in the cectelon to rebulld the

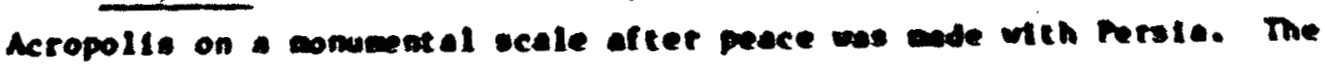
Parthenon wa bulle firet (447-430 B.C.), then the Propglate (437-432 B.C.). The ceaple of Achene wike vas nent (427-424 D.C.). and IIadit. Itwe

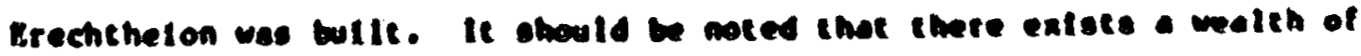

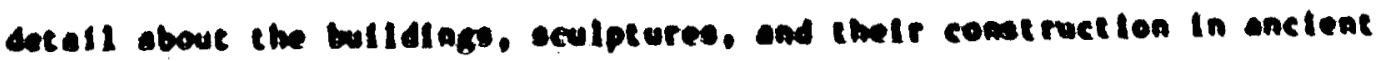

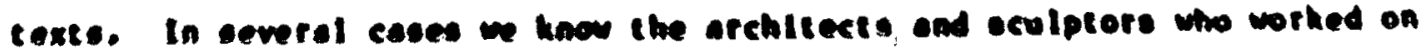
the project. We know that wenet wa relsed free the sale of old bullding

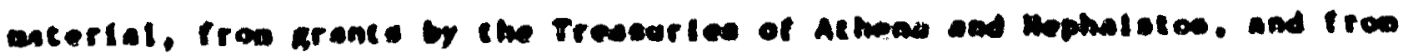

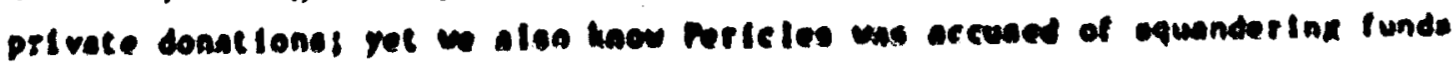

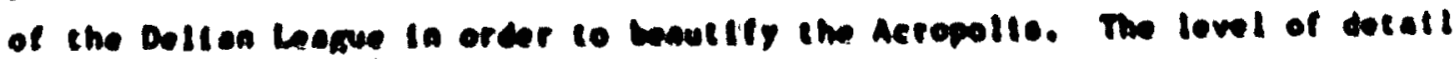

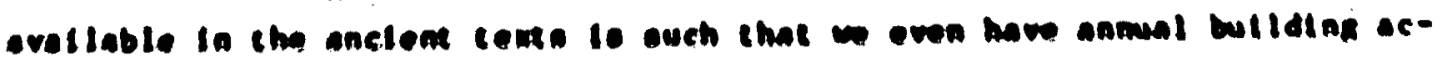
counte for tho Partmonom and Propitals wich were publicly displayed on the Acrapolla. (s4)

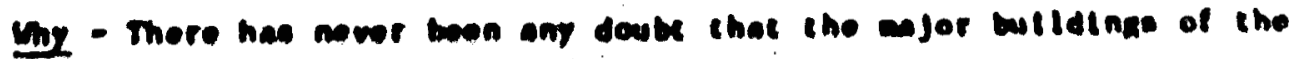

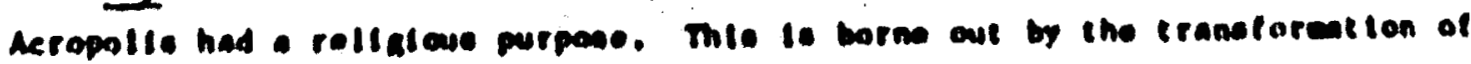

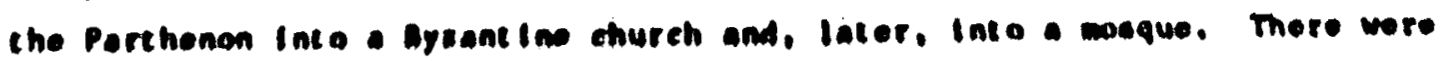

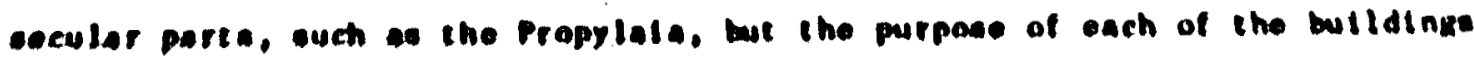
14 known.

Seace of Precervation - The lace forty ia flfly yoare havo ureaked mich havac on the Acropolle. The caunery has becose industriallied in inte portud. 
and the concomitant atmosphertc pollution and acid rain are dissolving away the marble sculptures and bulldings. The problew is so pronounced that the city held the second International syoposium on the detertoration of bullding stones in 1976. (S7) The Parthenon frleze and the caryatids are under tewporary shelters. There ace plans to replace the caryatids with casts and mive the originals to a protected environment. It is ironic that the caryatid renoved by Lord Elgin Is the one to be the nodel for the casts. Since ti has been Indoors for over 150 years, it is in far betcer condition than che others. $(54,55,57)$

The second problea is that steel bolts and girders were used in the extensive restoration done by Nicolas balanos between 1896 and 1933 . Irun was ortginally used in the construction, we te was lead coated to Inhthit rust. No such precaution was taken with the steel replacements. Nalde froo weaken1ng, steel expands as It corrodes. Inls extra stress has led to cracking of the arbie in which the steel is Ibbeded; In soce places ints has led to an lawediate danger of collapse. (ss)

The final factor contributing to the destruction of inis econuent is huan. The Parthenon we incect. though wolfted for the architectural meeds

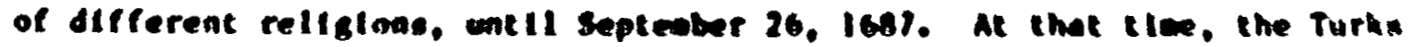
vere using the bullding as a ponder agaeline and it recelved a direct hit by a Venetian corter. The resultant explestea blew the teaple lato iwo parts. de-

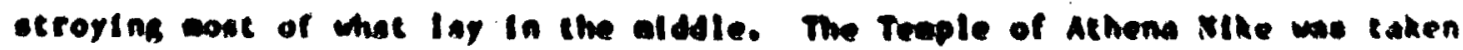

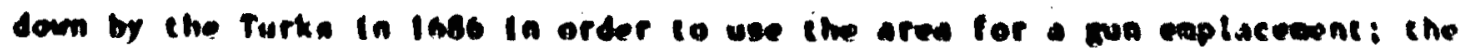

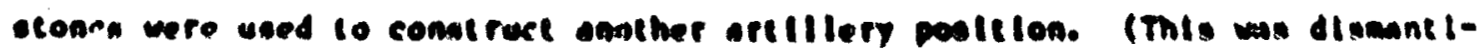

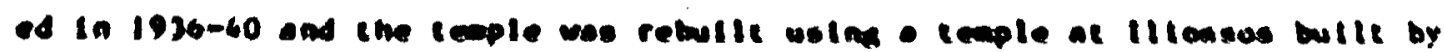

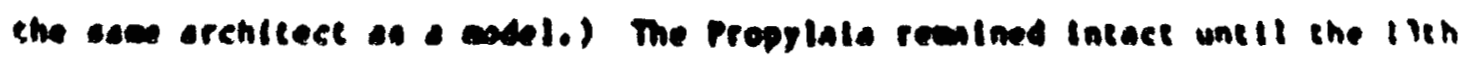

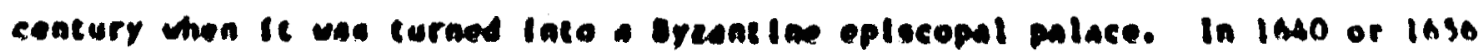

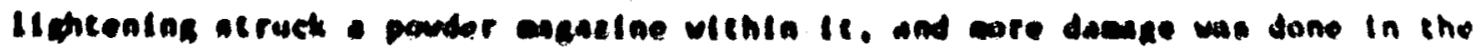

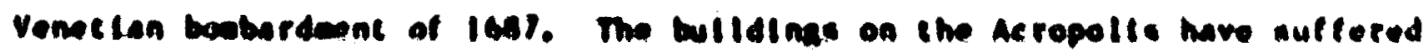

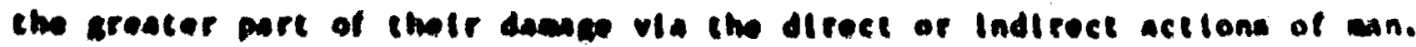

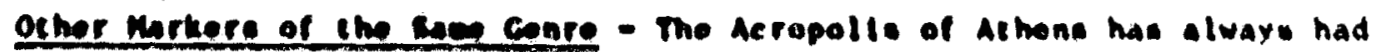

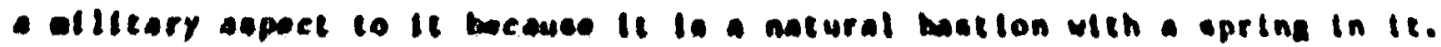

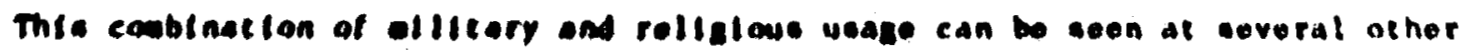

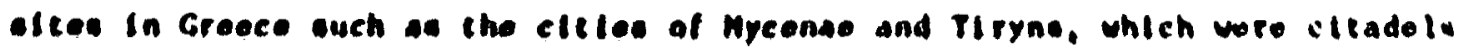

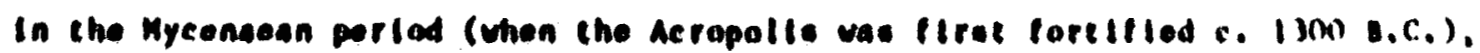
chile Argan and coptath had fortllled olevated areas of the cley conteaporary 
w th that of classical athens. The temples and secular architecture if the Acropolis find parallels In numerous other Greek cit les. The body of literalcure about them is so extensive that it forms a subspecialty in clasilcal archaeology, and so many other markers exist that they cannot be discussed Individually in this report.

History - The Acropolis is an example of an area with les monuments for which we can follow the history In some decal for over two millenta. This thread of information has continued through changes of religion, government. and occupying forces. Its spring and defensive position have attracted human habitation to the area since Neolithic tines (c. 5000 B.C.). In the Mycenaean period (c. 1400-1200 B.C.), a massive fortification wall was bulls, part of mich can wt 111 be seen today neat the Propylaia. His wall and an altar seer to have survived untIl the Persian sack of 480 B.C. Though lIttle Is know about the Acropolis between 1200-700 B.C. the continuity of the cults augBests cont i rued occupation.

The destruction of the Acropolis and its rebuilding under Pericles is described above. It wa comaldered to be such on artistic asterplece that little vas done to It in the following ceatorles. Alexander the Great added

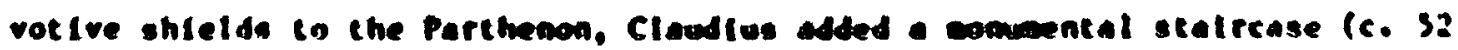
A.D.). and bronze Inscription howorlas nero was acted in the parthenon in 61 A.0. . but these cere el nor changes.

with the building of the cute gate in the third century A.D. I he

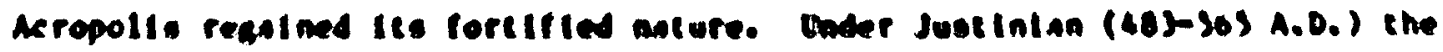

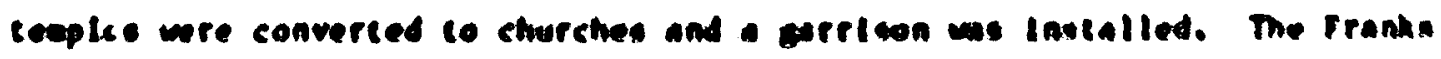

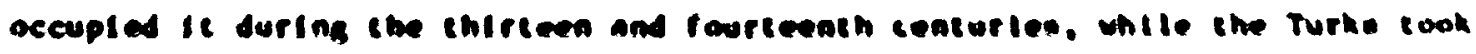

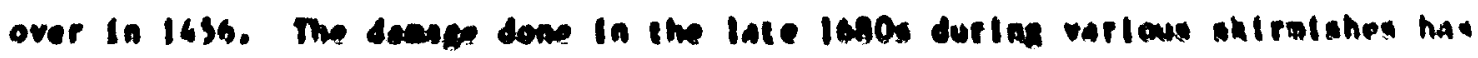

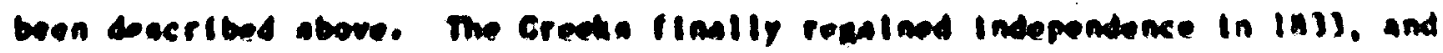

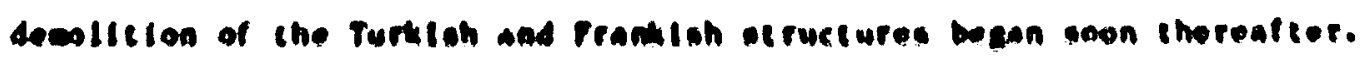

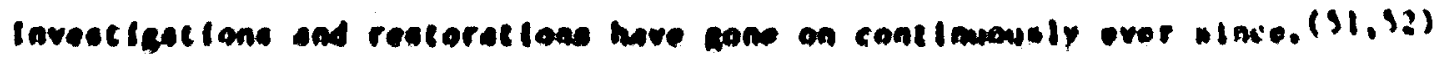

Relevance - The Acropolis can provide useful Information on several

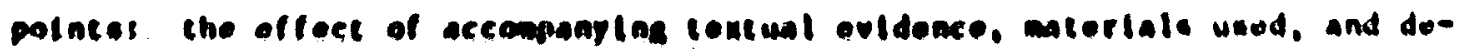

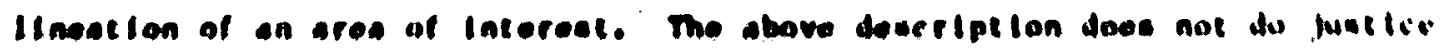

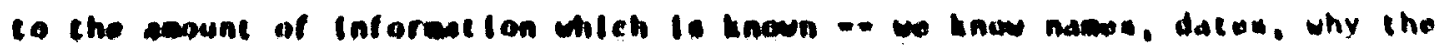

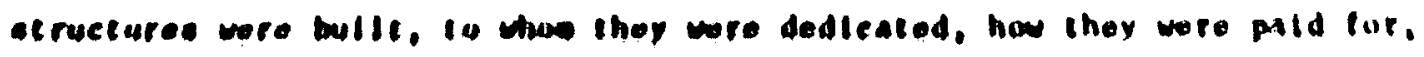
and oven ease of the politics involved. We even know, In rather detailed tore. about ching mich no langer extol. For example, wo know that the

80040

62 
Agrippa momine bore three different staties in its lifetime, although the monument itself anly records two, ind none survive today. A more milern -xample at the laformation st Ill extant can be seen in the dratings of the sculpturas an the parthenon prodiced by Jacques Carrey In 1674. These have proved inviluahle in telling us what was lost In the explosion of lobt and the postitions of the fragtonts which survived. $(52,54)$ The effect of written records on the survival of this Information cannot be overly stressed.

Another polnt to note is that what has survived is stone and not metal. The bronze shields and the inscription on the Parthenon were corn diwn in ant Iquity. The Inscription was deciphered by a study of the mounting holes. (53) The hase of the Agrippa wonument reating in place with its Inacriptions; the bronse aculpture proups have disappeared. Again and Again. the holeg for wounting tal objects are seen, wile the obfects are not. A glance throwgh a reference text for Greet Inscriptlons show that all but a sall muber of texts survtve In nonmetal bedia.(36) The few which we have Indicate that wal could survive for that perlod of tise. but that wost wetal neews to have heen recycled.

The present condition of the Actopils. due to the effects of ectd ratn. Indicates that not all atome is an acceptable nediu for repoltory arters. Linestones and arbles are mot afficlentis durable for a 10,000 yar anther. given the prewent levelo of ateosphertc mollutanta.

The construction techntque used in billding the vartous at ructures is

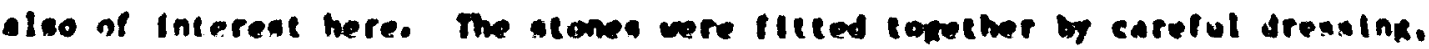
not by the use of anter. Thit obvinted the noed for certaln types at aninrenanc. ouch as potnting. The abmeare of a eateplate latertace, with its

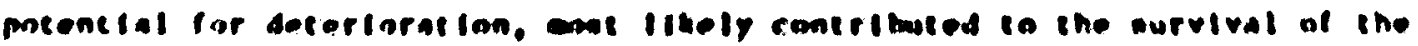

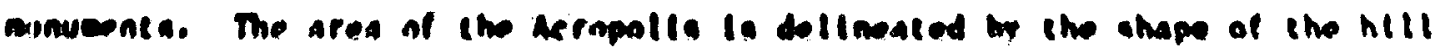

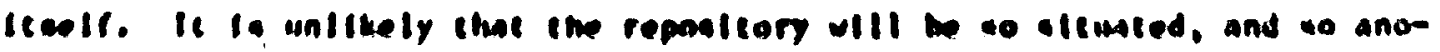

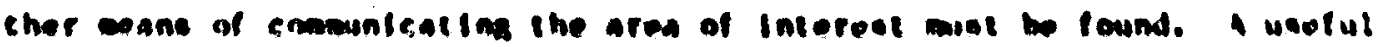

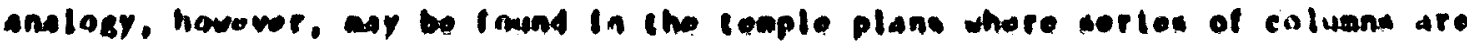

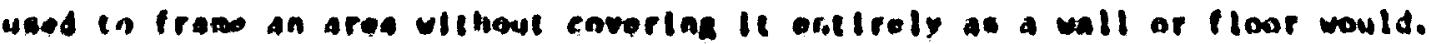

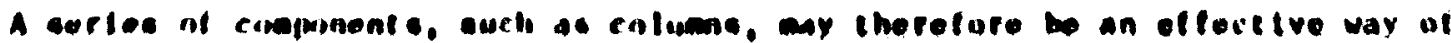
dolineating an arod ulth a olntima amount of materlat.

800101063 


\subsubsection{Greal Wall, China}

The Great wall of China has been called une of the woinders of the world. It originally stretched fron Shanhalkuan on the Yellow sea to kiayukuan in the west, a distance of some 1850 alles (Figure 3,1-7). Later dalitions, Loops, and inner walls have nearly doubled its length.

The first wall was bullt by Ch'in Shin Huang Ti wo unified China and wo, In chinese historles, Is better known for his "wining of the bouks than tor the wall. The Mall was begun in 221 B.c.. Inediately after the tinal conquest of unification, and was completed in 210 B.C. The rapid tee of completion was possible because the Wall incorporated some 1300 olles of walls bullt In earlier tines. The actual bilding of the wall was entrusted to a general veny t'ien.

The Mall was begun by setting up a serles of watch towero along the trontier. These were generally 40 tt high and 40 te square at the base, caparing to 30 ft equare at the sumft, and were loceted the length of two bow bhots apart. This beant that the entire length of the Wall could be effectively defended. Alter the wich towere were construcled, they wete jolned by wall

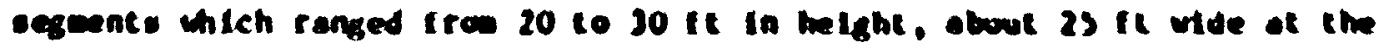

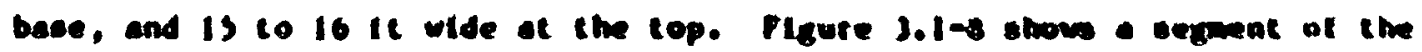
wa11. $(s+-0)$

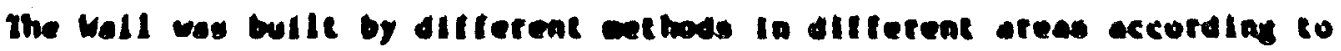

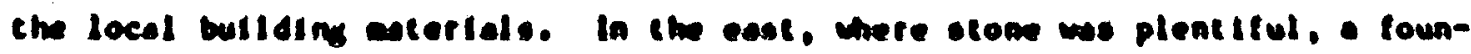
dation of rubble we latd without corter. The wall we bulls of dry imped

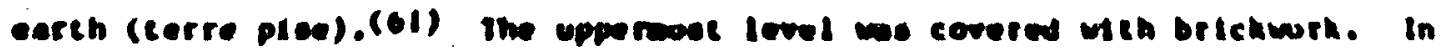

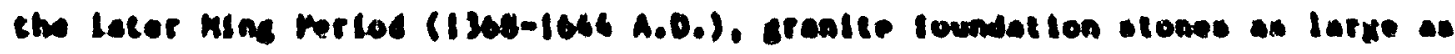
16 le by 4 te wre used. The rubble or carthen core of lim unlls wa taced

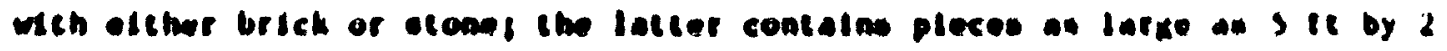

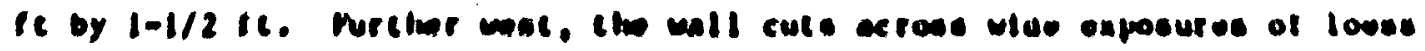

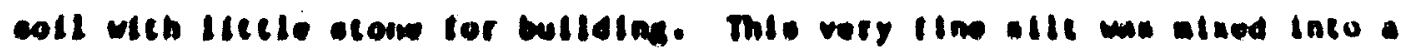
eluery and pour betwen trame ta create the wall. witeh was lacud with

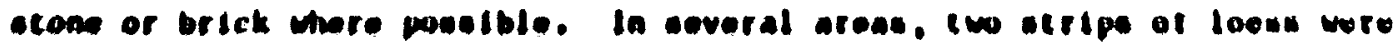

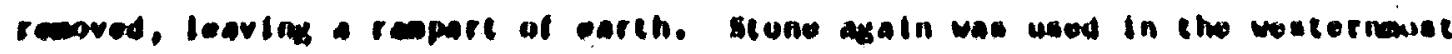

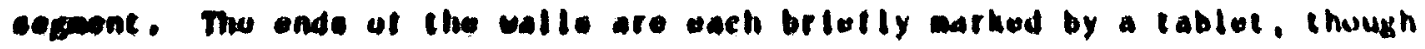
the cexte eay not be very informative to wo loday. Tho und in kiayukuan

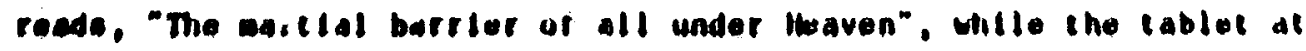

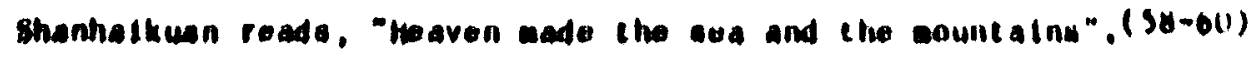




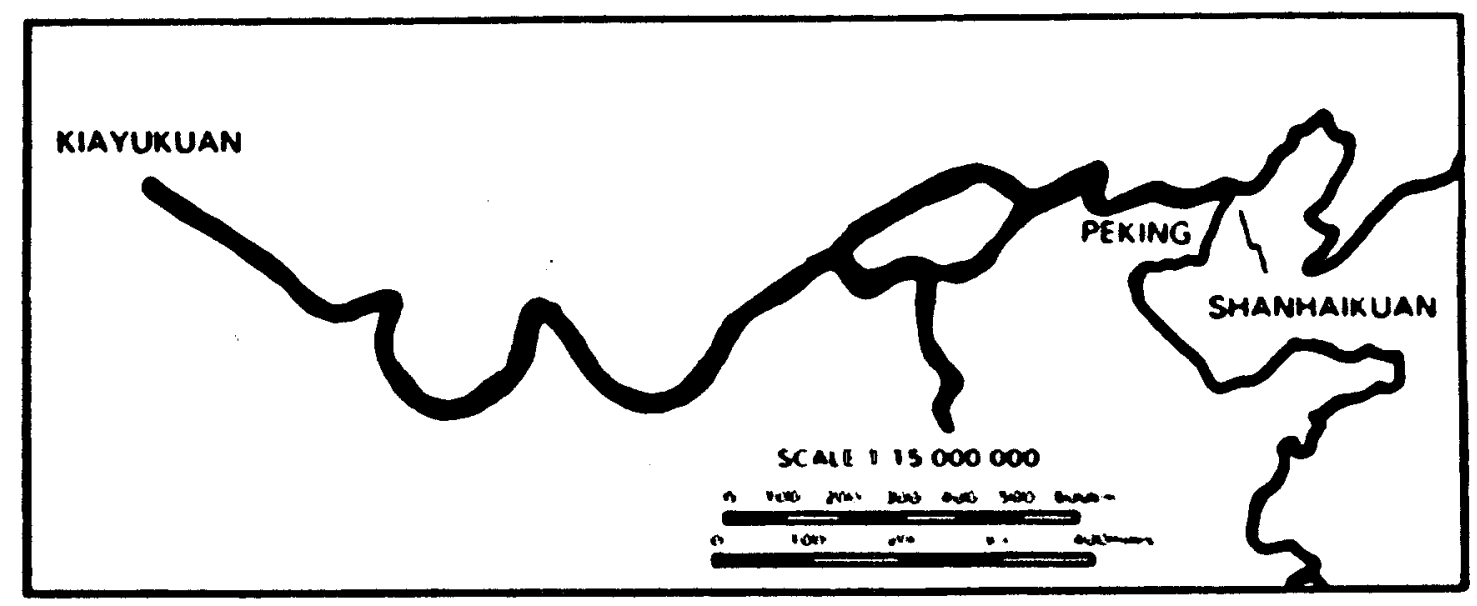

E Iqure 3.1-7 The Great Vall of China

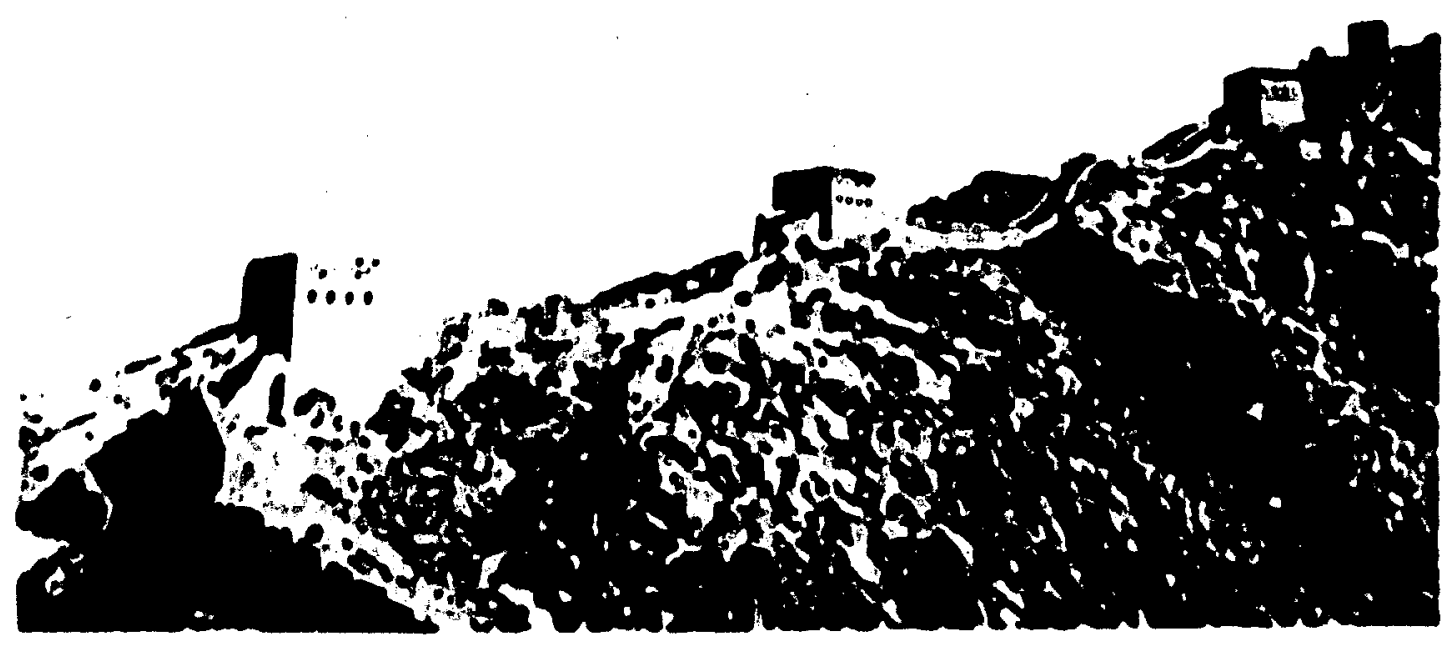

Ant. 351

Pleure 1,1-h a Segenen of lig liseal Mall

$81910 \quad 1065$


Who/khen - The Idea of the sall was concelved oy Ch' in Shth Huang TI, and was carrled out by his general yeng t'len. The sonstruction was stared in 221 B.C. and inded in 210 B.C.

thy - The cout rimonly stated reason for the wall, and one which is borne out hy the Inscription at Kiayukuan, was that th was to keep the barbatlans out. But the lavish expenditure of anpover and captit on an endeavor which did not work has prompted other sugrestions. The conseruction ot the wall began very shortiy after faperor Ch'in finished comuering China. It has been suggested that the wall was bullt co provide gafiful employment for all the vast number of soldlers wo were now unewaloyed. Another suggestion was that the vall not only served a mlltary purpose tut also marked the coutward IImit of desirable expanglon draving an arbltrary line besween the nomadc and apricultural populationa. (62) Fimally, the wall served to ear phasize that there was now one ChIna under one tuler utth a Ingle northern border. and so ewphasized the bonds between the formerly warting states. $(59,60)$

state of Pregervation - The section of the wall near Rakling was rebullt during the MIng Perlod (1360-1664 A.D.) and Is in excellent condition. This Is the area mont courista presently ree. Forther west, in the lows section of the count ry. the wall w. ante subject to deterloration given the anmet of construction. Even so, at the turn of the centwry. an wetican traveler stll found sections standing to is it in heldhe. and towers curviving io in fe. (SB)

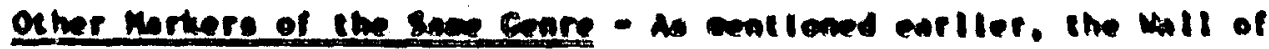

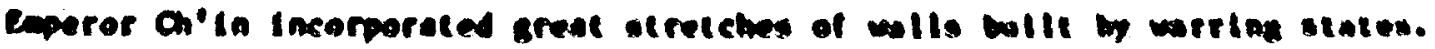

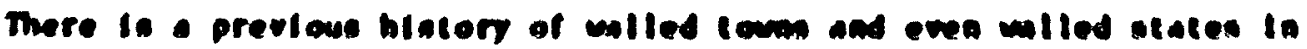

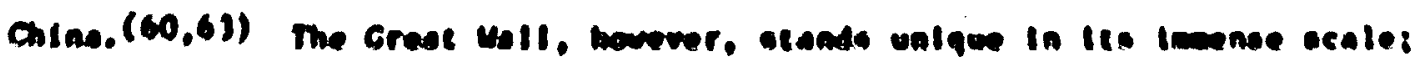

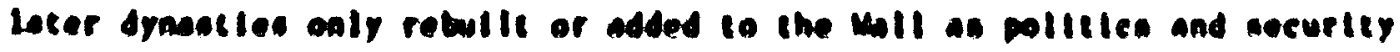
requelres.

Letery - The histery of the Greas Mall is Inemorably Dound up with the

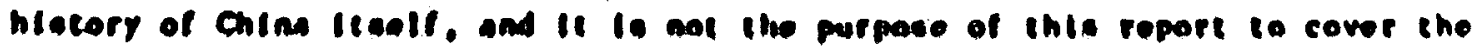

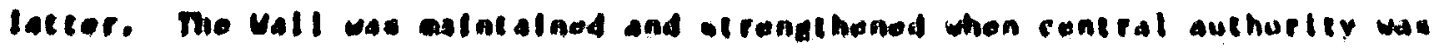
etrans and loft to detertarate vien te waw not. Durling the Han dynasty

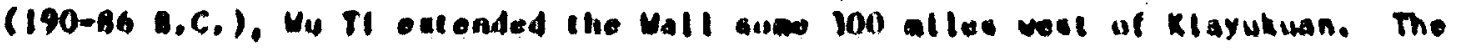
Wu Dynacy (305-535 A.0.) entetalned the Valt and added more than n(K) allos of

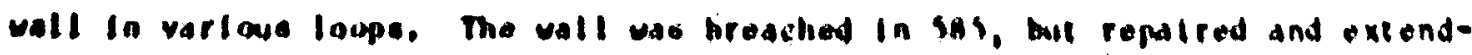

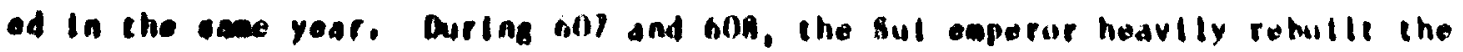
80040
$10 \% 6$ 
wall from the Yellow Seat to tle Yellow River. The ensuling T'ang dyatisy (6)8-906 A.D.), however, refused to malntaln and repair the Wall. ilth the fall of the T'ang dynasty the northerners crussed over, only to fill lator under the Mongol Invasion (thiteenth century). The wall was of lictle laportance to the Mongols, although Genghts Khan had been defeated for years in his attempts to get over the wall. The Hongols were throm out by a native Chinese dynasty, the Ming (1568-1644 A.D.) who probably carried nut aore construction on the Wall than any other ruling house since Eaperor Ch'In. The any plaques and inscriptions in the vall coomeoorating the rebuliding of sectlons of the wall date to the Ming perlod. These can still be seen and read today. The Manchus (1646-1911 A.D.) were xortherners who replaced the Mings, but had been Invited across the wall by a Ving eaperor fighting for his throne.

This takes the history of the wall dow to this century. The wall has been breached and repalted but never forgotten. Dor does chls history do justice to the amount of Ilterature wich has grom up around the will. rangting from poena about its beaty to tales of the horrors endured by the conscripted laborers wo bullt It. Passing the gate at Rlanwiman was tantesount to leaving all that we cloflited Ia the world and is often no portrayed in Chinese Itcerature. In short. It was an Integral part of Chinese wlitary and cultural hiatory. emarima several centuries and chanpes in povernment. $(59,60,61)$

Relevance - the Grest Wall is on exumple of a morker wich hos ben mat

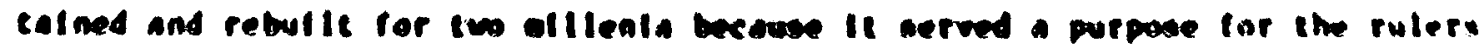
of the counery. As werh it ahowe the poteatial ourvivel of the ippostiory arkers, since they itwo serwe protect twe tunstlon.

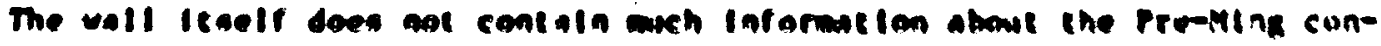

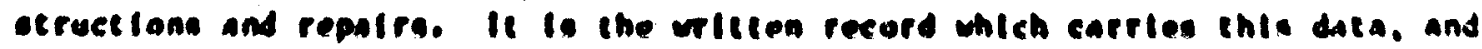

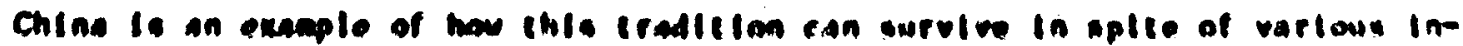

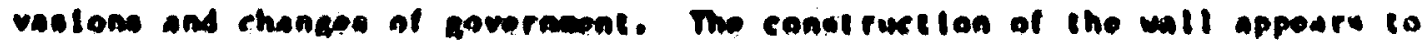

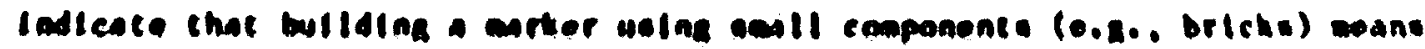

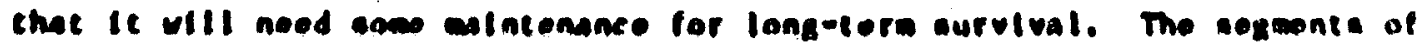
ceeped earth or laese, hovever. are etlll vistblo even after the facting of brickwark he fallen avep.

$$
80148 \quad 1067
$$




\subsection{DIsclssim}

This section sumartzeg how the information on the various monuments presented in Section 3.1 relates to the Issues on repository marking discussed in Chapter 2. The discusston will follow the order presented in Chapter 2 -message existence, detectability, and comprehensibilicy.

\subsubsection{Message Existence}

A point wich is aentloned repeatediy In Section 3.1 is the laportance of written records to our understanding of the arcient monuments. The purposes of the Pyranids, the Acropolis, and the Great wall are known because they were bullt by literate cultures wo made conteaporary records. Mis information has elther survived to the present time, or has been recovered and spread in a wder audience through scholarly work. The level of detall is such that we not only know why they wete bulli, but by whow and, sowet loses, even how they were pald for. Much less Is know about the taxca IImes, stomehenge, and the Serpent mund. Their bullders are know only by peneral cultural manes, not

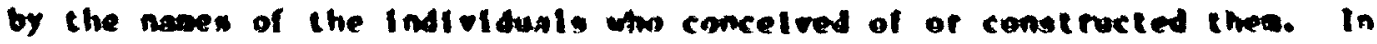
other words, it appears that:

- Level III and IV Information as onit be cartied by the wititen wrd, and the repaltery enrting syated should therefore incorpurate shit.

- The haeping of records conteoporary with the eveat is apcessary in order to altow the ourvited of the Inturation.

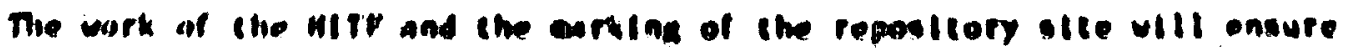
thet the Intelat recard is ande. However and whenever the recerd of the

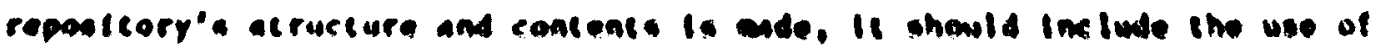
wricten recorda.

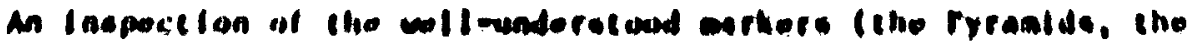

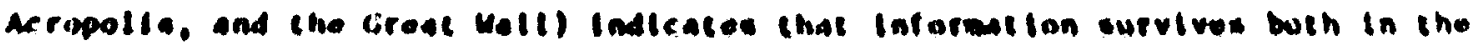
conumente thomelvos and throuph offecteo archival biteriat. In ono case,

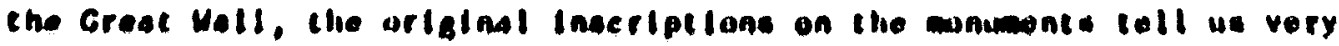

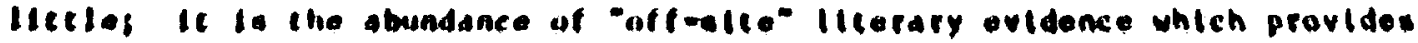
the Inforadetion. Enauring that dotatlod Information is lucatod both un-atio and elactiorn will laprove lis Ithellimed of survival. 
The monuments discussed in Section 3.1 may also be used to commene on message survivability. Several of the gonusents, the Acropolis and the ldaca IInes in particular. have suffered their worst degradations at the hands of an, not of nature. The monwents whlch survived in becter condition were those wich mintwized the need tor active maintenance. The Acrupolis has no mortar used in the construction of its vartous bulldings, wile the Nazca Lines, Serpent Mound, and stonehenge needed no wortar due to their means uf construction. In contrast, the creat wall used brlck and wortar construction over wuch of Its length and it needed active waintenance over the centurles to survive. (The Great Wall, however, Is an exapple that such extended aintenance is posstble tor at least two thuosand yeats.) Another point is that all the wonuments are manuf actured fros wat olght be called "natural baterlals". 1.e., stone or earth. These materials need only to be shaped to be used in the monuments; they requite no adticlonal processing (e.g. obelsing or casting). The cholce of these anterials ay reflect the lechnological IIatt of the cultures wich used them. howervet. Chis does not negate the tact that

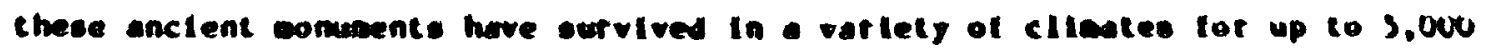
years. It should also be noted that betels ate not oultable for carkero be-

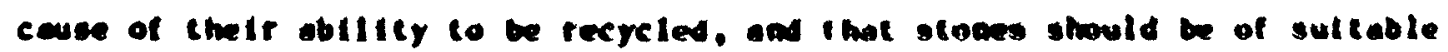

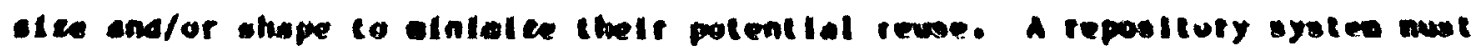
be destgned with these pitats in oind.

\section{2 .2 meene wecteblity}

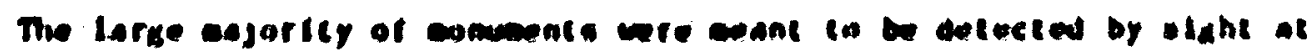

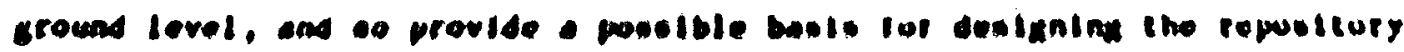

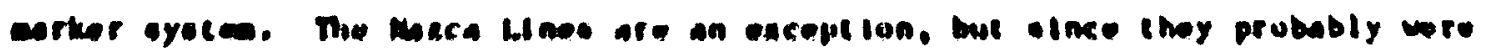

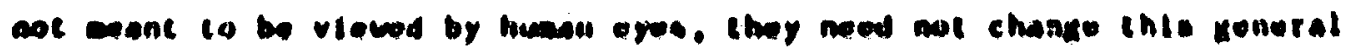
otervectua.

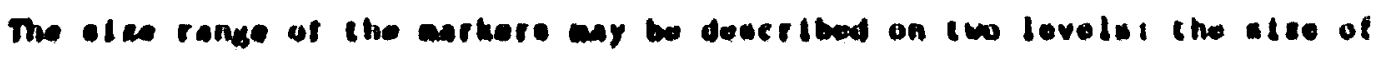
che Individunt componente and the alie of the entire wonument. The raike weon

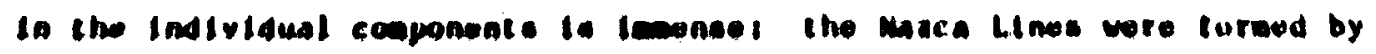

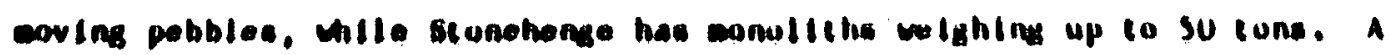

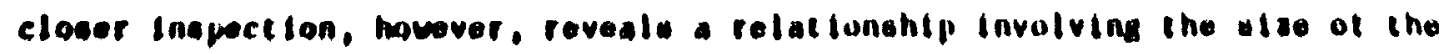
componone, the acceosiblitiy of the public to the aarter, and the etale of

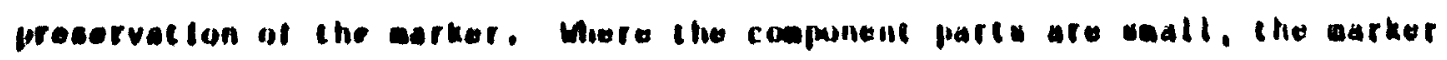

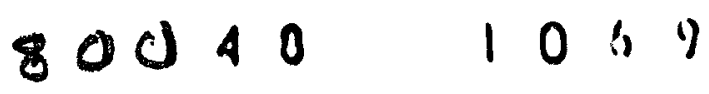


seegs to have survived because it was located in an lsolated reglon. This Is the case with the Nazca lines and with some of the smaller stone rings in the British Isles.

Three of the monuments discussed in the prevlous section are loctid near large population centers and have survived. The large sizes of the stones at Stonehenge have bade then rather difficult to topple and vandalize. On the other hand, the Pyramids were made of saller stones and have been used as giarties. They have survived only because of the lawense number of stones used in thefr construction. The Great Wall has been alintalned because it served a protect Ive function and is of cultural ieportance.

A far nore subtle relationship exists between the slee of the Individual components and the ize of the entire monument. Stonehenge, the Acropolls, the Pyrafis, and the serpent wownd can all be caken In at a single glance. The patterns and forms of the wonuments are inmediately perceptible. The perception of form and content holds true for the Great Wall as vell, even though the monument cannot be viewed In Its entirety except, perhaps, by sacelilte. An Inability to percelve a woment leads to a lack of understanding about It. The rasca uines are an exapole of this, and the phenomenon may explain wy the otone circle of Avebury, wich Is far larger than stonehenge, I" less widely houm. The cooponent parts of avebury are sall compered to the scale on wich they are set. and It is epporentil easy to stand in one part and not realtice that the reailaing cection of the monument

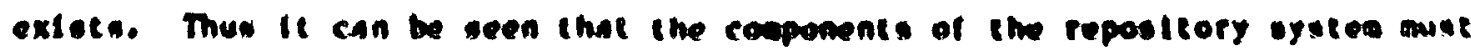

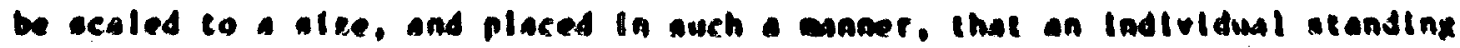
on the alte recognteen the pottern of the arting syoten.

\subsubsection{Mesese Coeprehenolbilliy}

Writeen recerde have the ablitiy to cafry lovel ill and iv typos of laforactoa, even though langunges and culturen ay change dracatically. In

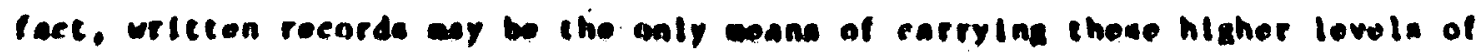
taforantions the hitatery of stanohonge polnte out the posetble currupt ton which can creep inte intariation witeh to orally traneatited. The une of

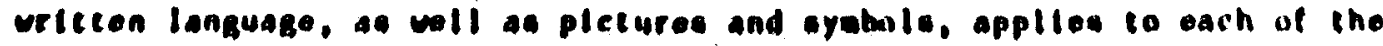

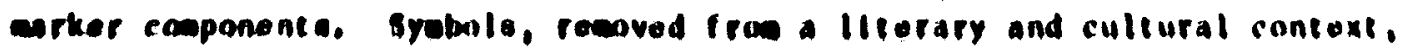
generally casinot carry higher levels of Inforeation. The sorpont Mound is an 
example of this phenomenon. The pattern of an entire marking iystem. like those of the anclent monuments, must be recognizable in order iur the monument t) be properly comprehended. This may be done by using component parts with suttable stzes and locations. 
This chapter presents a preliminary marker system destgn which Incorporates maily of the positive features found in the anclent monumes. Since the monusents discussed In Chapter 3 are only a small selection of the materlal surviving in antiquity, this chapter will begin by presenting a deduction of useful options which can be draw fros this larger body of information (Section 4.1). The marker systeo deslgn is presented In Section 4.2, with vartous options wich address the different issues that are presented in Chapter 2. It may not be necessary to Incorporate all of these features in the final design, but that decision rests with the HItr. Section 4.3 concerns the messages that the aarker wil convey.

\subsection{DEDUCTION OP USEFUL DESIGN OPTIOAs}

The previous chapter described several mnwenta wilch have survired for extended perlods of time. With this Information as background, we nov turn to the problew of destgning a eatker systev for a nurleat wote repository. Useful optlons (eaterials, construction, and the weane by wich the Information

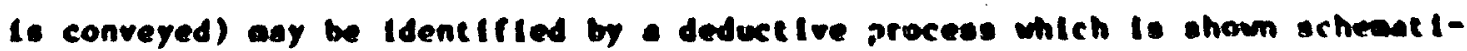
cally in Pigure $4.1-1$.

Archeeological aterials way be divided Into iw categortec, ortantc and inorgentc. The former category is not sultable becoune orgentc catertals do not survive for extended pertads of line except in lavorable clienten. e.R..

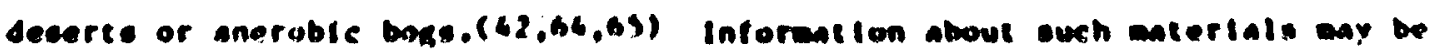
scored If they will be lacated in protected environment (e.t.. paper in a climace-contralled Ilbrary). Wut they are not approprtate for on-ilse markeru. All the enckere discused in the previous chapter are ande of Inortantc anteriala.

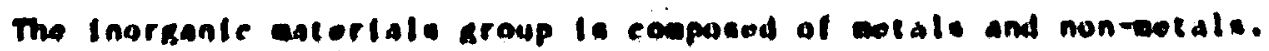
weal a are me acceptable trom an arehaentonleal polnt of vitow bocaune they

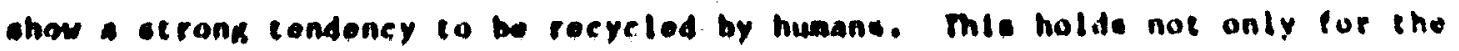

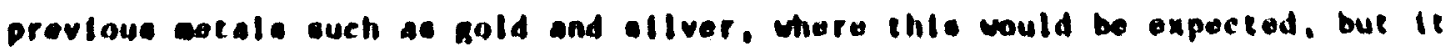

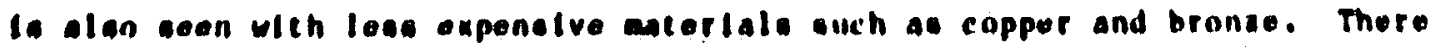

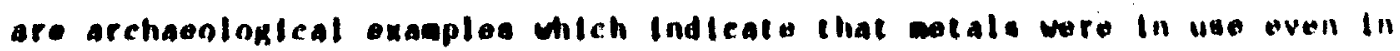

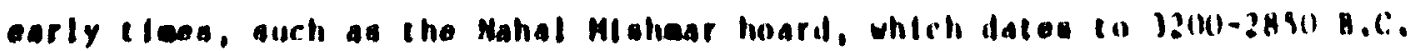

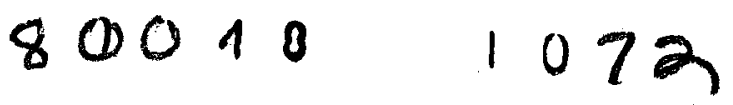




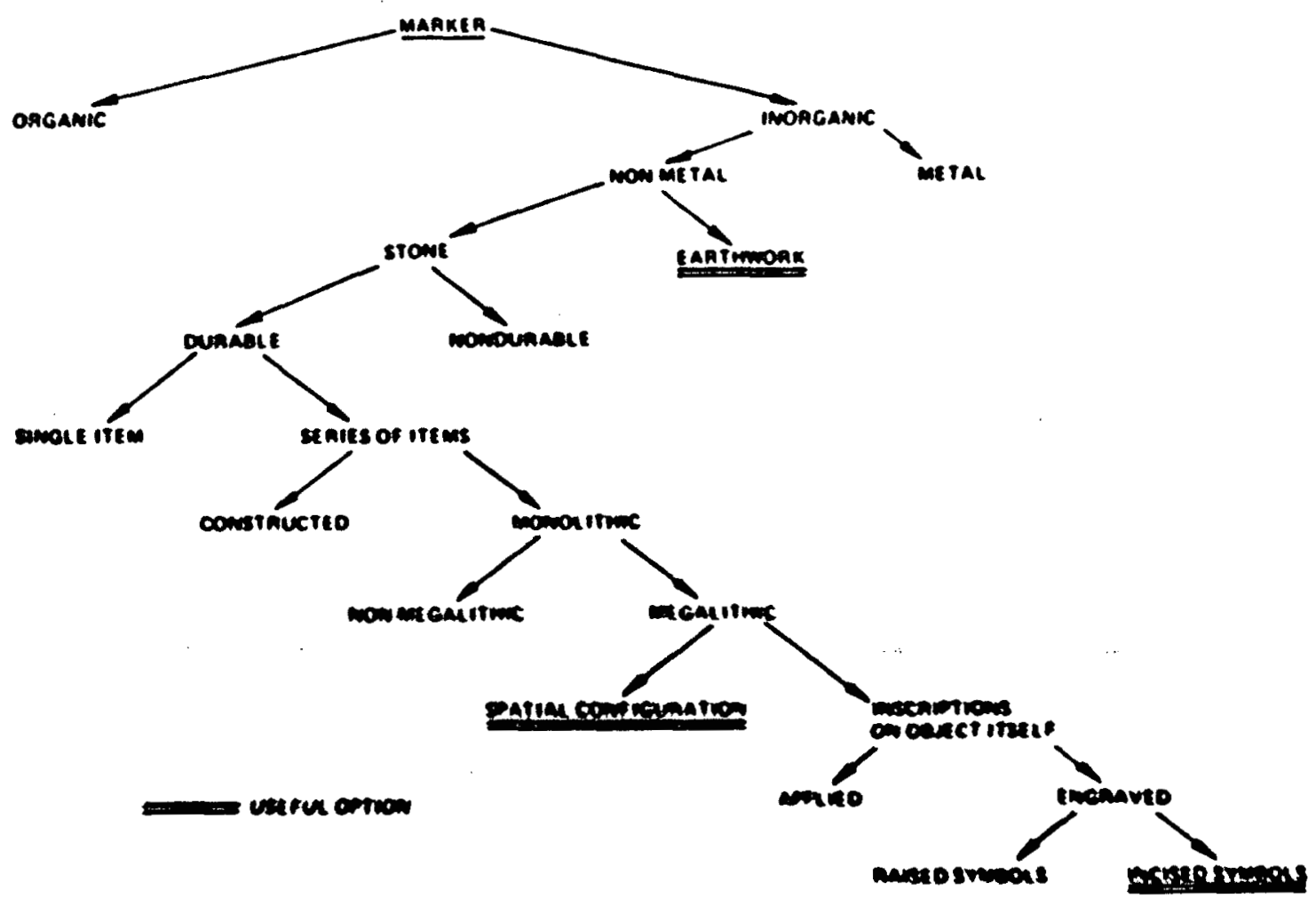

Figure 4.1-1 Lopic Diencen lof restul opelone

and contal ned over 400 copper objects, but these appear to be ine exceptions wich eacaped belng elied dow and reused. (66) (since we do lind these

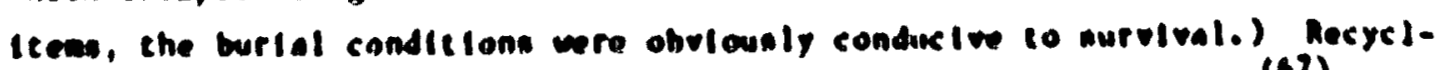
Ing. however. Is seen apein and agein in the archseoloslcal record. (67)

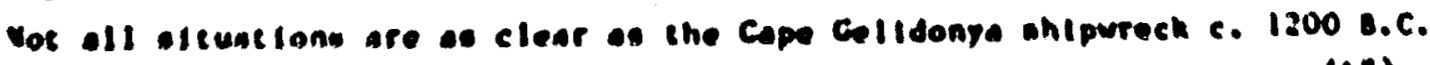

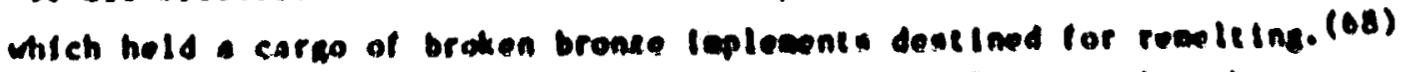
In cont casen we ara left vith negallive evidence. Tap enample. there were a

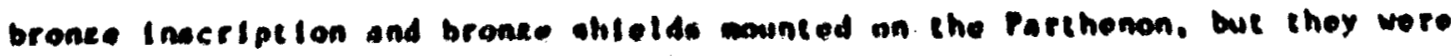
recoved. (the cent wa reconat rueted from a arudy of the nolon left by tho counc ing pina. (33) we only know the ehtelda oxtated trow contemporary dower(pt tons.)

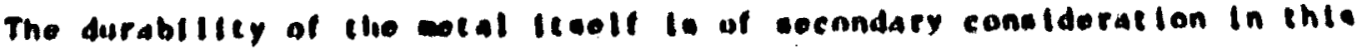
cace. The nonepreclaus cotale avallable in the archaoological perlode, oog., copper, tin, bronee, and lead are eyplcally found In atate that would indecate they are not oufficiently durable to be used for a 10,160 yoar arker. 
There: are, however, molern met ils, e.ge, titanlum, whloh are fir more durable than these. But the archieologlcal cuidence Indfiates that the Intrinste value of metal mikes to highly probable that te will be recycled. In other words, although modern metals my be sufficlently durable, markers made of such materlals are not likely to survive. It is this aspect, f.e., human action, whlch removes metal from further consideration.

A non-metal marker may be constructed out of earth or stone. The bank and ditch enclosing the stone ring of Stonehenge, Serpent Mound, and the Great Wall are examples of surviving earthworks. This, therefore, is a useful opton but one which is restricted to conveying faforation in Its form or outIine, thereby limiting the complexity of information It can carry. It would be suttable for delineating the reposttory area. Annther posstbllity wold be to make the carthwork in the fora of an International hasardous waste symbol.

The marker systen may also be constructed out of atone. Within this category, however, there are some unacceptable aterlals. Softer stones. e.g., nteatite, are too eanily damaged by erosion, abrasion, or Intentional disf igurewent to make desirable markers.

Marbles and llwestones were comoniy used In bulldings and anonumes. They have, however undergone severe detertoration within the last hundred years or wo due to the Increase in Industrial mollution. The Acromils in Creece has several bulldingw mich are milt of arble and are nuffering noticeably fron severe deterioration. The antked changes which have occurred uithin the lawt century ay be seen in comparing a cant of one nt the Perthenon relietw with liom it Inoks today. (69) The replacements for she Porch of the Moldena are ade frow a cast laken from the antden Lard II In brought to England. since te he been indoors. It is In far beter condition. (Ss)

Indugertal pollution has created a conservation problew unteh is re-

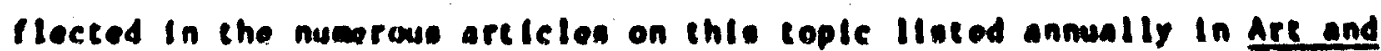

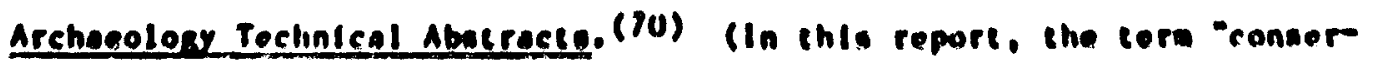
vation" rafere in the repatr, conaglidation, and protection of ant lquition and worke of art.) The ajoficy of these artlclos aro concerned with arbles and

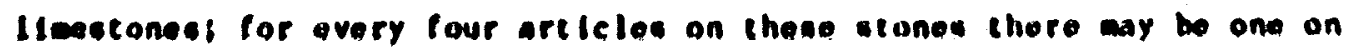
andetone. Crante and baselt are rarely mentioned. The materlate which are mere comenn in the conservatinn llterature are those which requlre the wout repeir, reconatruction, and createont to proserve. The wuro durable ato-

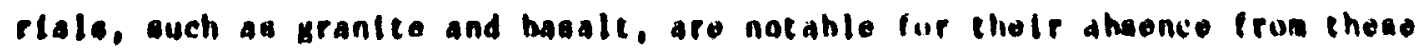
11964

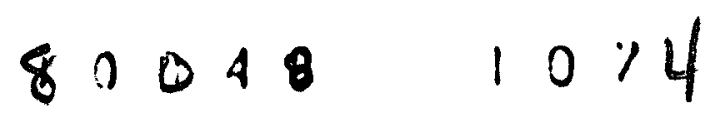


A final polnt In the argu ent agalnst the use of marbles or llmestune ls the fact that they are often burned for $11 \mathrm{me}$. Many pleces of antiquity have disappeared in kllns. (7I)

Recent work by Lewin and Charnla indicate that linestone and aurbles show sigiftcant direct solublity in environaental water. (The lack of ralinfall In Egypt helps to explain the better condition of the monuments there.) Quartzite and arkosic sandstone appear to detorlorate ante fron stress Incurred by freeze/thaw and wet/dry cycllng. (72) Sindstancs also tend to sutfer from surface friablity (69), a factor detribetal to preserving an incripton.

Tuff Is a material which has been used for bulldings. (73) Although it Is strong, the ease with untch te can be carved akes to unsultable for a repository miker. It may be destroyed too eislly hy vandillsa.

The reminting rockn wich ay be sultable for the arkers wuld have the following characteriatica: hard, compact, non-irltele, and relatively homigeneous. The harder a stone 19, the more difficult it is in wrk, ond therefiste the more difficult it in to deface or abrade. The terw ccompact" here ts used In the sense if heinp, fine-aralned and lacking cavlcles. If a sinne lacks chia characterintic. two difficultion result: the inablitiy en have sharply cut inmeriptinns, and the abtilty of water to collert in the carlitex. rewulting in acrelerated corrosion. IThis wold elisinate vestcular, but not

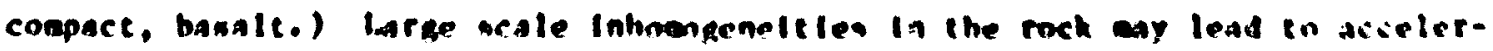
ated corrosion along grain boundarlea. One homogeneowe rech is quarta. but

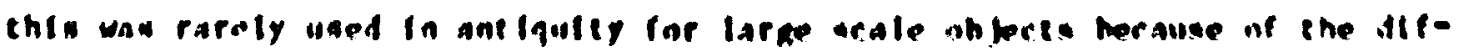

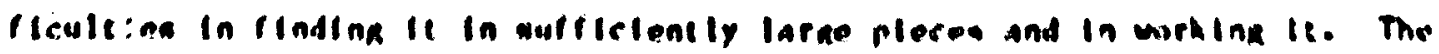

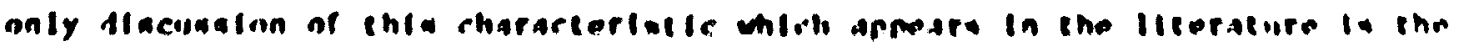

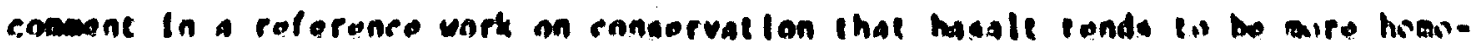

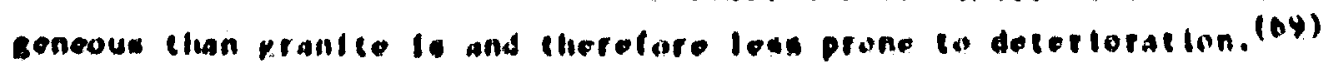

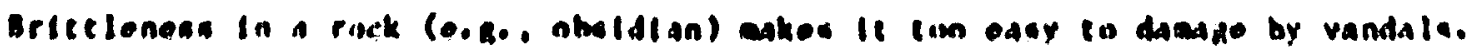

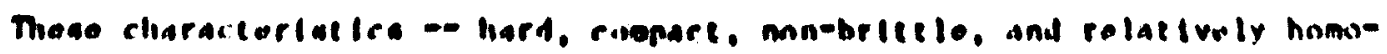

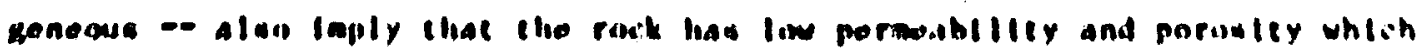
Inhible vater frive callecting ulthin le olther from the atomphore ur hy weking te up trom the aoll. It le tho upeako of vater uhlich can load en corraston or to tho bulldup of sale frum tho kpounduator. The lateor cryatalltee out on the ourface of the ohject exposed to the atmephere. Thts phenomonon has baen noted on both stone and fired clay ohjocte, athi may roulle

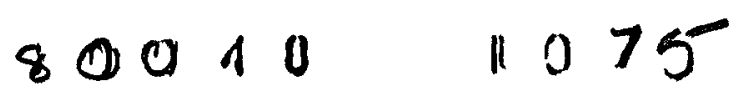


In exfollation of the surface of the oblect. (69,74) This problem wlll the minimized by site selectlon factors which make it unlikely far a repositury to he sted under ur very ne.er surface budfes of wieler. There ite several rucks which fit the characterlatics ment loned here. cianteg, basalt, perphing, and quartz are some examples. Modern miterlals sclence also allows the posibibiity of creating a man-made stone for this purpose, but these have no aribacloglcal precedenta and therefore fall outside the range of this discussion.

Having suggested a class of acceptable miterlals, we now turn to the plan of the marker systew. The first question to address is whether :here should be a single marker or a serles of arkers. A alngle marker, he it a pyramid, temple, or figure, tends tn ark a spot. It is, then, a point estimate. A gerteg of markers, such as those at Stonehenge or the coluans around the Parthenon, tends to define an area and so is anre appropriate inr the project at hand.

A mingle marker han the added disadvantage of belnk ton easily destroycd. thereby leaving the reponftory without any miting watsoever. In wrder in bulld a whle arker which is sufflctent in withstand the ravakes of vandilInm and $t$ Ime, It mut be mullt on an emormoss scale like the prratals of Egypt. A nerten of arkers, on the other hand, would be leas contir co erect and uould provide the dealon with oume redundancy. For example, the plan of stonehenge can twe arawn, even though third of the clones are iniating.

The next guevtion in wether each arker liself should the alnale plece

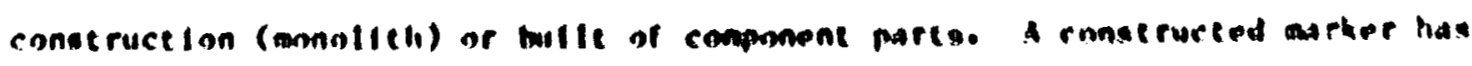

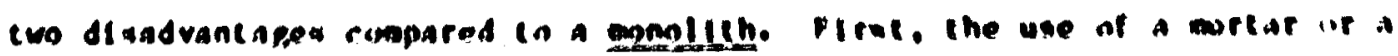

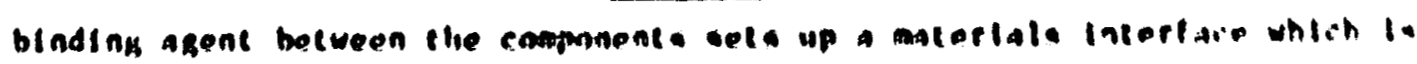

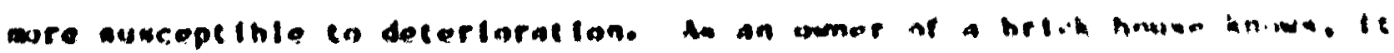

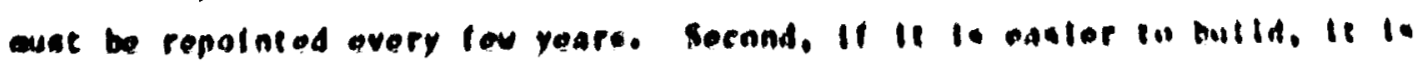

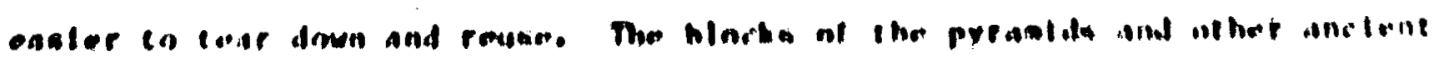

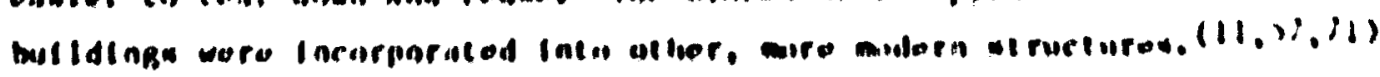

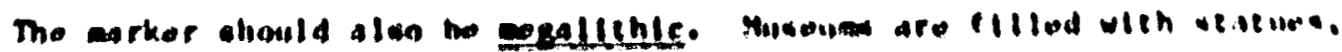

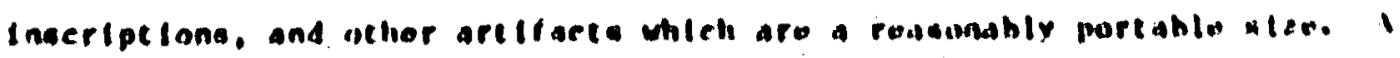

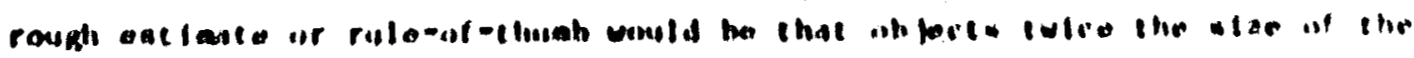

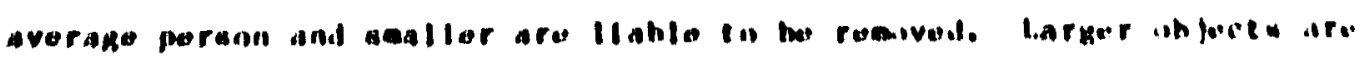

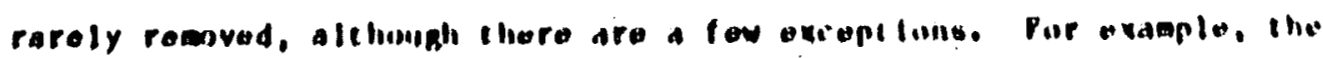

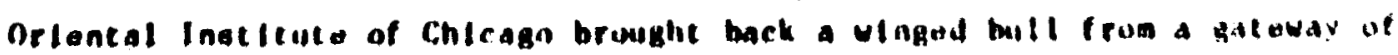

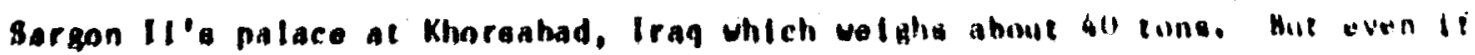


a few of the mirkers are taken, the remilnder sumld contilue to consey the desired informition.

The serles of monoliths call convey informition by two meins: spatlal configuration and Inscriptions on the object itself. Is with the earthwrk, the spatial configurition can convey only a particular iype of informition delineating the repository area or forming the hazdrdous wase svabol.

The planar surfaces of each ronolith are qulte sultable for carrying message in symollc and/or textull form. The mesage should not he affixed to the marker, since this is resoved too caslly (cf. the Inscription on the Acropol1s). Nor should it be applled to the arker (e-g-. palnt) since this is too casily scraped of arker Itself shmild be engraved with the message.

Another point to consider is whether the ietceting or syobols should be ralsed from ot cilt into the surface of the sirket. Yost anclent Inscriptluns are just that: they are cut Intn the stone or metol. Ralsed figures are cenerally reserved for artistic works. 1.e.. tellefs. Cutting the messare into the stone creates crevices In wich raln water could collect. leading to cnrroston or, If It freckes, to stress. However. the cholce of a destrable rock would wintalze the potentiat dasge. Ralned letters, on the other hand, can

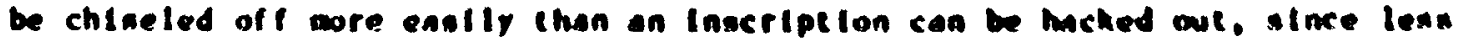
wcone has to be removed, and ay be deaned apre easily by vandallsa.

A final and seall polnt to discuss is the depth to which the Inacitpiton shoult be cul. It whould be noted that the depth could te oet or the potenclat corronton rate of the stone so emare that the Insctiption would witl be lentble efter 10,900 yeara. Fer perapective. It should be noled inat anclent Inecrlptionw wera uaually rut an are than a few allilmeters deep, and oven

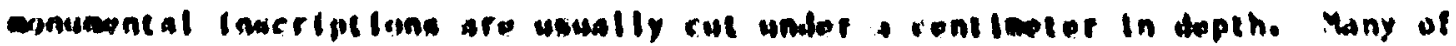

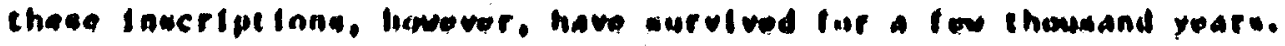

In wien, three unaful options for conveying Inforation abust the ropusttory elte have been Identifledi

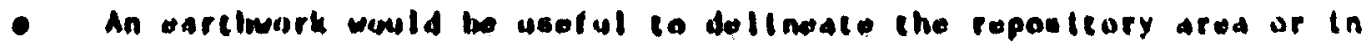
the whape of the hatardous antertal wyebol.

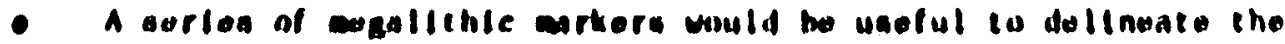
reperalcury area ur in the whape of the hadardous matortal uymbol.

- Inocriptiona on each of the esaltiho would be unotul to cunvoy Inforation about the repostiory and tie contonts In wrabols and languagu un the mogalleh lewalt.

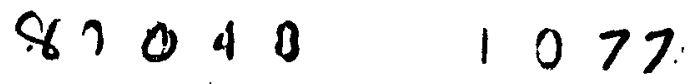


4. 2 MARKE.K SYSTHM UF.SLICK

The preliminary repository marker system design presented here contalins three mi for components:

- A sertes of monoltths defining the periater of the repostenry site.

- An earthwork In the forw of the hazardous wacerial warning syabol.

- A marker at the center of the site.

Each component will be discussed in a separate section.

\subsubsection{Pertmeter Monoliths}

The disusgion of this perimeter monolith falls inco two sections, the placewent of the markers and a description of the arker Itself. Several factors should be constdered in placing the warkers:

- The disposal area (and buffer cone if desited) should be defined vit', reasonable accuracy.

- The spacing of the artery should allow an investigator lu stand at one marker and wee the wext anther on elther slde.

- A suffictent maber of markers should be wsed so that the placement pactern can be rentifled evan It gone anthers are loot.

The periseter ring of conolith deflines the area to avold when drilling In order co preclude Intercepting, canteter and bringlan part of the wate

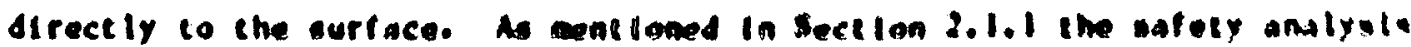

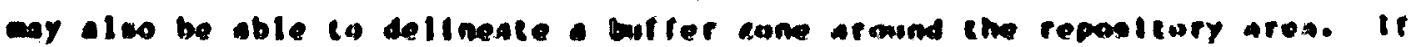

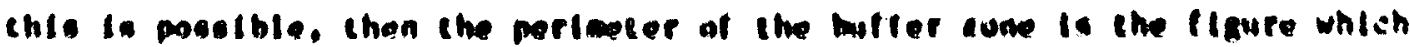
should be oue lined.

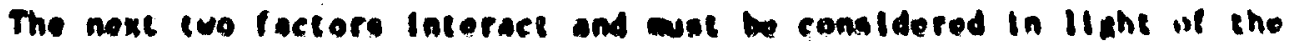

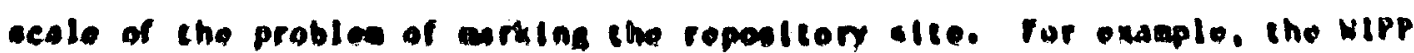

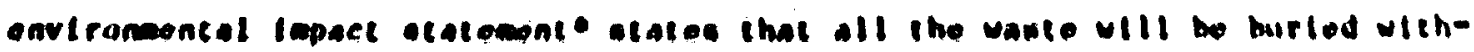

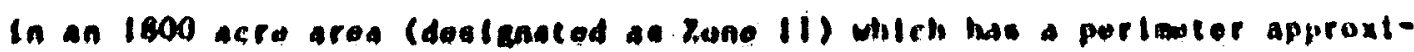

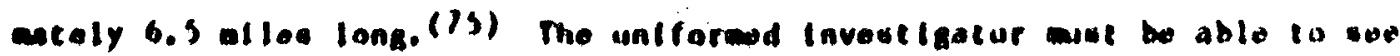

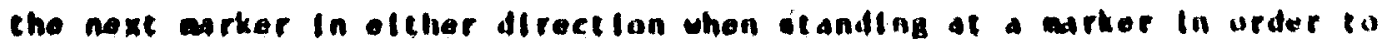
raalle that these artuefe fore a pattern. Althingh the actual placemont of

The UIPP alte Ia chosen only for lllustrat tre purposes thera are no plans at preaent in bury hlgh-lavel waste at that slio.

$80010 \quad 1078$


the markers will be determined by the copography di the slte, a spaclng inf approximately 400 yards between them may be suffictent. Given the helght of the markers (cf. below), they would be discernible at these distances in a flat, unwonded terratn.

Thts suggested placement pattern would result in 29 to 30 markers belak used to delincato the MIPP atte. A siallar nuaher of stones are used in the sarsen circlo of Stonehenge, which Ioplies that there will be suffirlent markers to recongtruct the pattern if snes of the stones are destroved or cacted of $\mathrm{tn}$ moseums. As ment loned above. the plan of Stonehenge itn the recongtructed even though more than a third of the stones have disappeared over the lant $5,00 n$ yeara.

The opt Ion of siaply using four stones to upt the rardinal polnts if the area Is not acceptable for several reasons. First, the scale Is so large that the uninformed Inve,tigator would not be able to see any of the ather arkers and so would int recogntse the orea to avold when drilling. Secrnd, the Inas of any one arker would destroy the patern. Fonally. with auch a sall nume

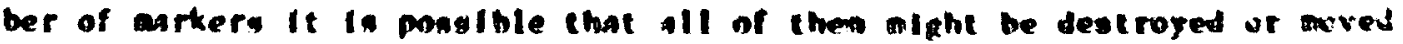
during the time perind of Interent.

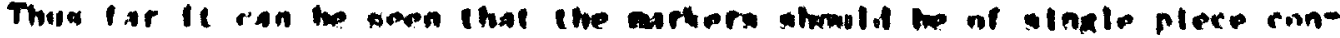

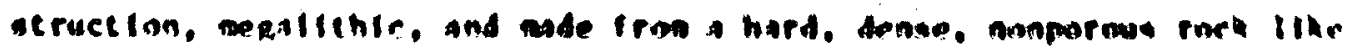

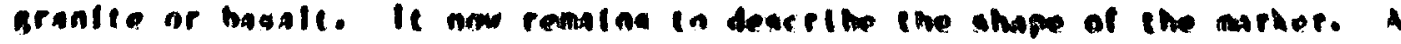

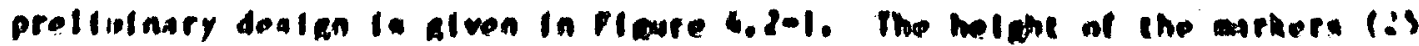

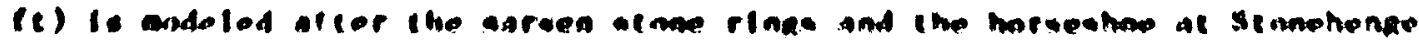

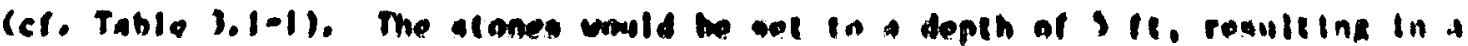
astker which ecande 20 it above the ground levol. Vallte stanehente. however.

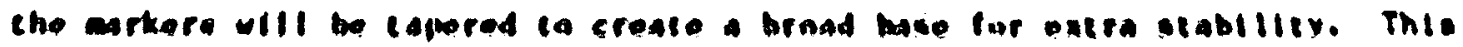

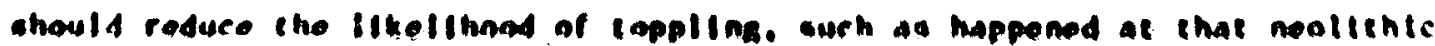

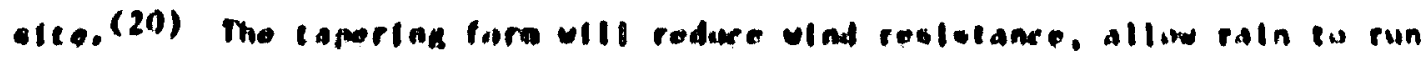

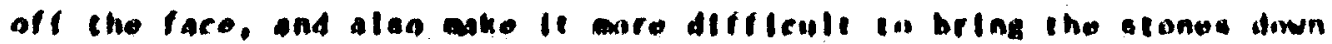

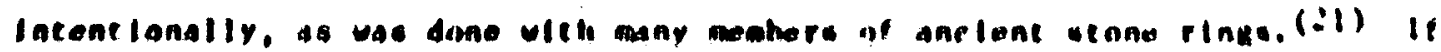

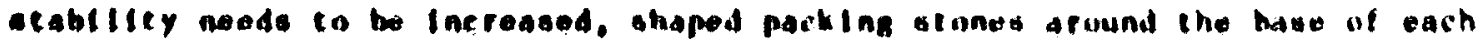
enollih can he used.

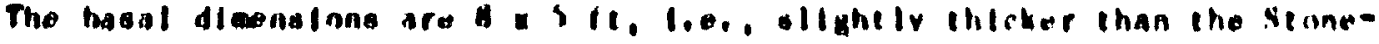

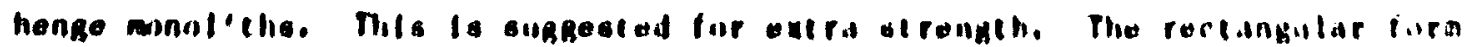

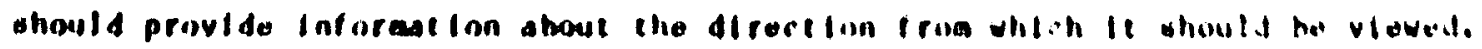
Laving one of the broad faces of the annolith blank vill entalle the not lull

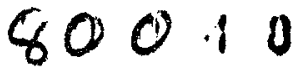


a) Front

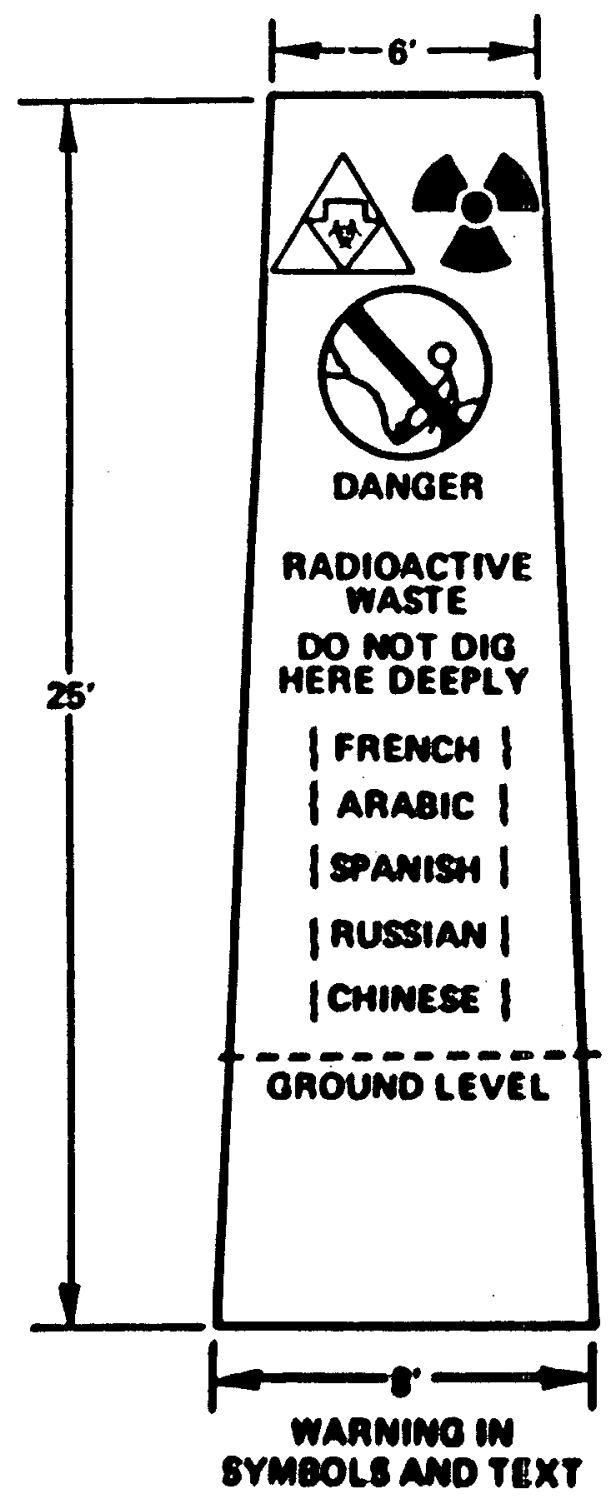

b) S1 de

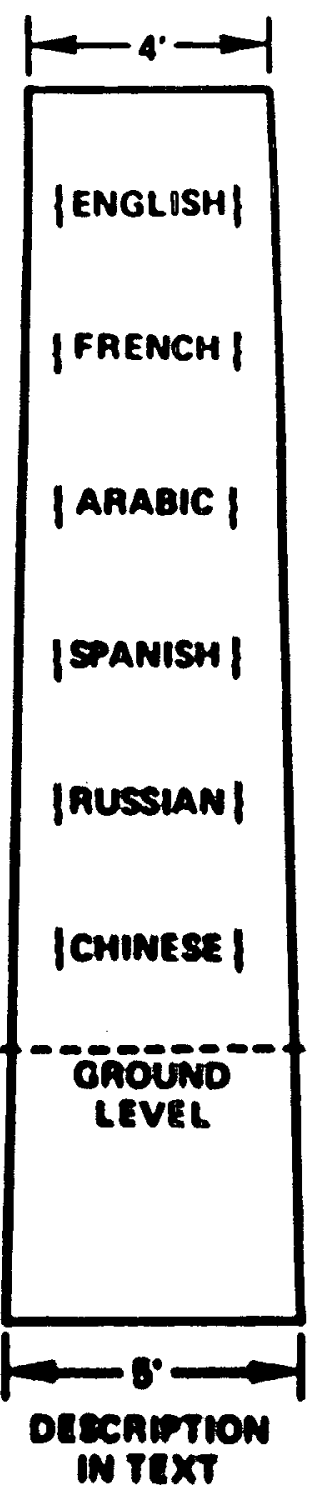

c) $51 d x$

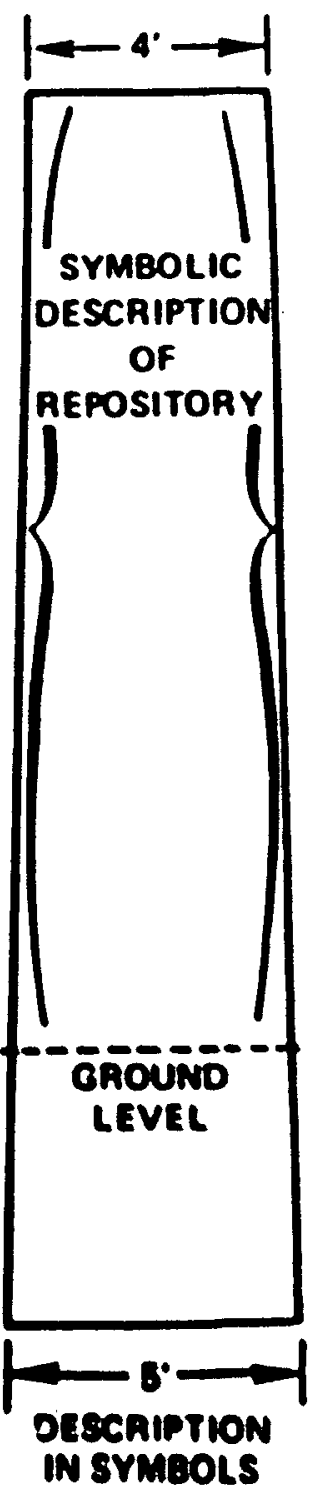

\section{Meure 4.2-1 Morlecter Monollen}

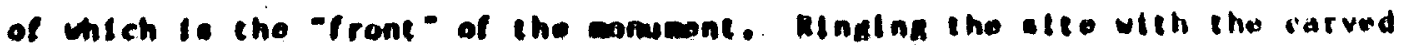

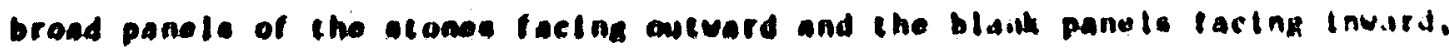
should cell the unlafares inwestenter where he or she to otanding. 1.0. out ide of the repantiocy area.

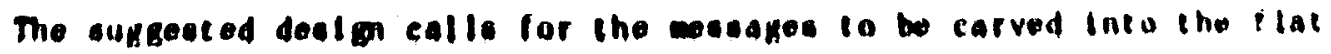

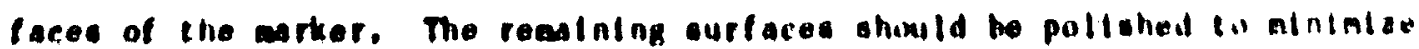
80040
$\log D$ 


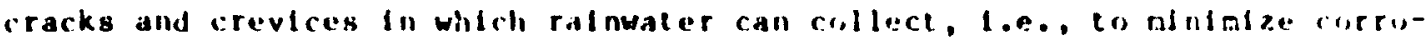
ston and detertoration. If wind erosion Is a potential problem at a repository site, the message can be protected by a ralsed band around the edge of the panel to bear the brunt of the ulnd damage. (The facade of che treasury at Petra, Jordan is in wuch betcer condition than wost at that site. It has been suggested that this is due to the fact that ints tacade is recessed inco the cliff walls.)(76) The wessages carved on these panels w11 be fully discussed in Section 4.3, but it should be noted that the syabol in the upper left of Figure 4.2-la is the hasardous baterial varning syobol developed by the HITF.

\subsubsection{Earthwork}

If the deciston is made that the repository artere should be visible from the alr and should call atention to the slte, an eartwork can be incorporated in the witker system destgn. The very nature of en earthwork llatto

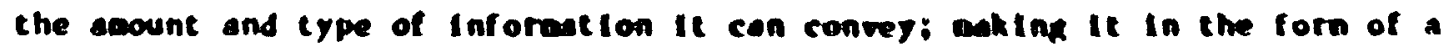

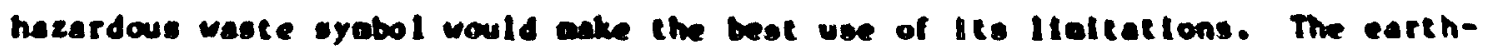
works of tngland are forned by ustan the aterlat encarated from the ditch

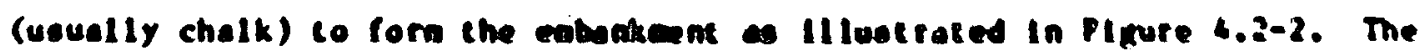
bank at stonehenge is t it high and 20 te wide. while the one at Arebury was

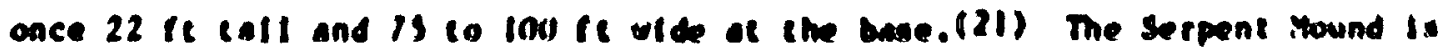
s te high and 20 ts vide. The clay body of the serpent cowere a ctone core. The het ghe of this enrter. therefore. ohould be at least o ft. but the helitht

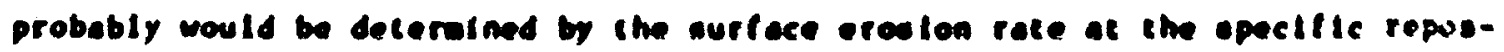

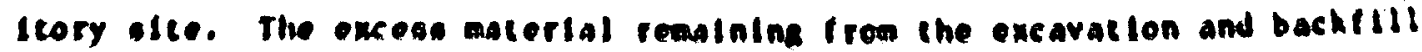
of the reposticty could be used in the formation of the cere of the eartmiork.

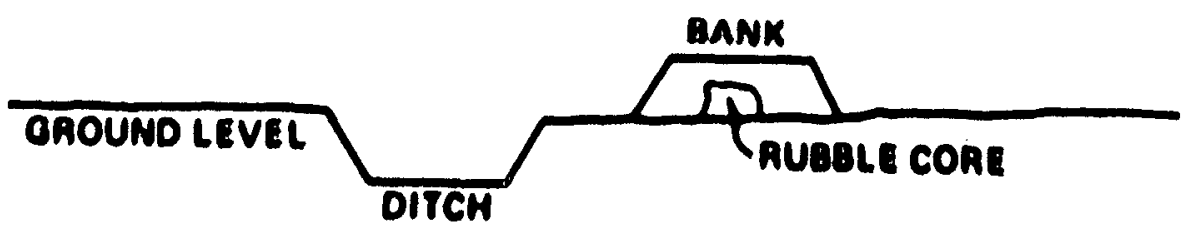

Plgure 4.2-2 Rebanicent and Ditch Conotruction (Bection)

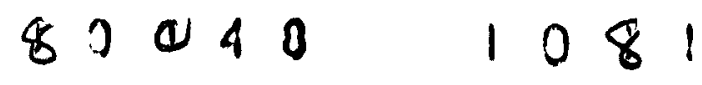


The visibflity of the embinkment can be anhanced by packing tire tup w: it with a miterlil which will Inhtbit vegetat ive growth, e.ge. crustied stone. This change In vegetation, as well as the origlnal color contrast hetweon the stone and soll, would be quite vistble from the atr much as ate the lise. lines. Other possibllttes Include packing it wh thanetlc sand to create a mgnetic anomaly.

Unltke the perfweter monollths, the earthwork has no definlze stze requirements since it does not define a particular area. The stze would he decerwined by a tradeof between cost and the scale on which it will the viewed. The greater the scale, the greater the helght from which it is vistble unt Il the width of the earthwork is no longer discernible. Ising arihaenIngical examples ag mods, the bank at Avebury Is a guarter of a alle In diameter, wlle the large cleared trapezold of the Sazca IInea aciures is half alle on Itg longest side: an eabankwent ulthin this slep ranke wruld be approprlate.

It should be noted that this component of the anther system entalts the largest environeental Iopact, particularty if steps are taken tn Inhisit vege-

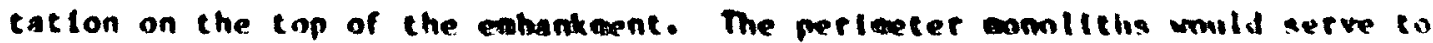
dellneate the ite area, warn the motentlal Int nudera, and dearrine the rrosisltory in more detall than is posolble to be done by an earthworh. The conoltths, however. would be a sertes of polnts when vieust from the alt and

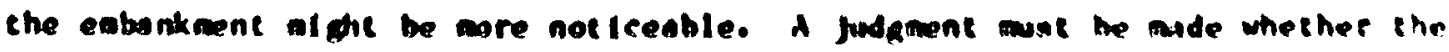

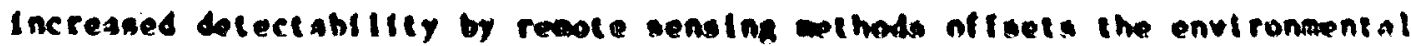
1apact.

\subsubsection{Incerlor Marker}

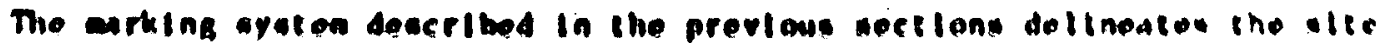

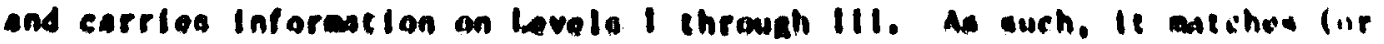

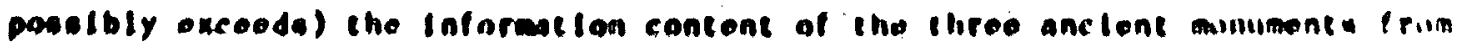

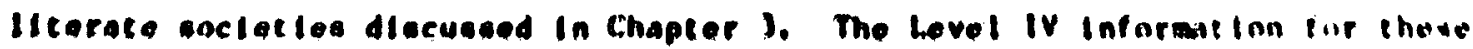
monumente come from tho of -ette archival matertal. For an added lovel if

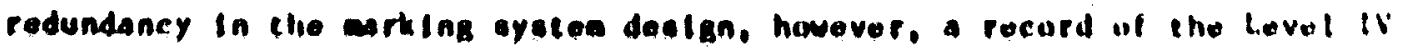

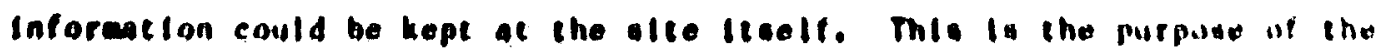
Intertar arker.

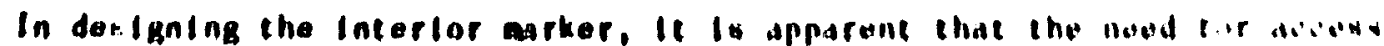

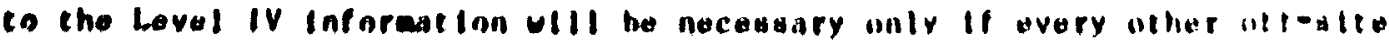

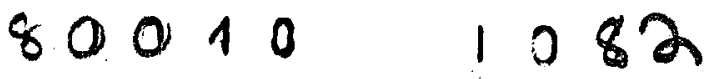


record has been destroyed. (lt is not within the purview of this paper to comment upon the type of cataclysm which could lead to this stiuation or whether suffictent technology could be regalned after such an event withtn the time frame of Interest.) The level IV Information, therefore, need not be Immediately accessible to the Investigator. The prelioinary destgn for the Intertor marker has the Level iv information stored in an underground vault, while the position and purpose of the vault is marked by a sertes of monoliths and a tumilus.

A tumulus $1 \mathrm{~s}$ the namp for an anctent burial cound. Here te refers to the wound of earth ralsed over a vault contalning the level iv inforoation. The vault is located below ground to create a wore stahle envitonent for lts contents (e.R.. removing It frow freeze-thaw, wet/dry cycles.(7T) The anound above it serves as an additional buffer hetween the conients of the vault and the fluctuating environment, as well as being a marker.

In order to draw added attent $l$ on to this arker. It should be placed in the center of the stte and warked by four nonolitha. A prelialnary design for the cumalus and intertor monoliths is piven in Figure $4.2-3$. The helght of
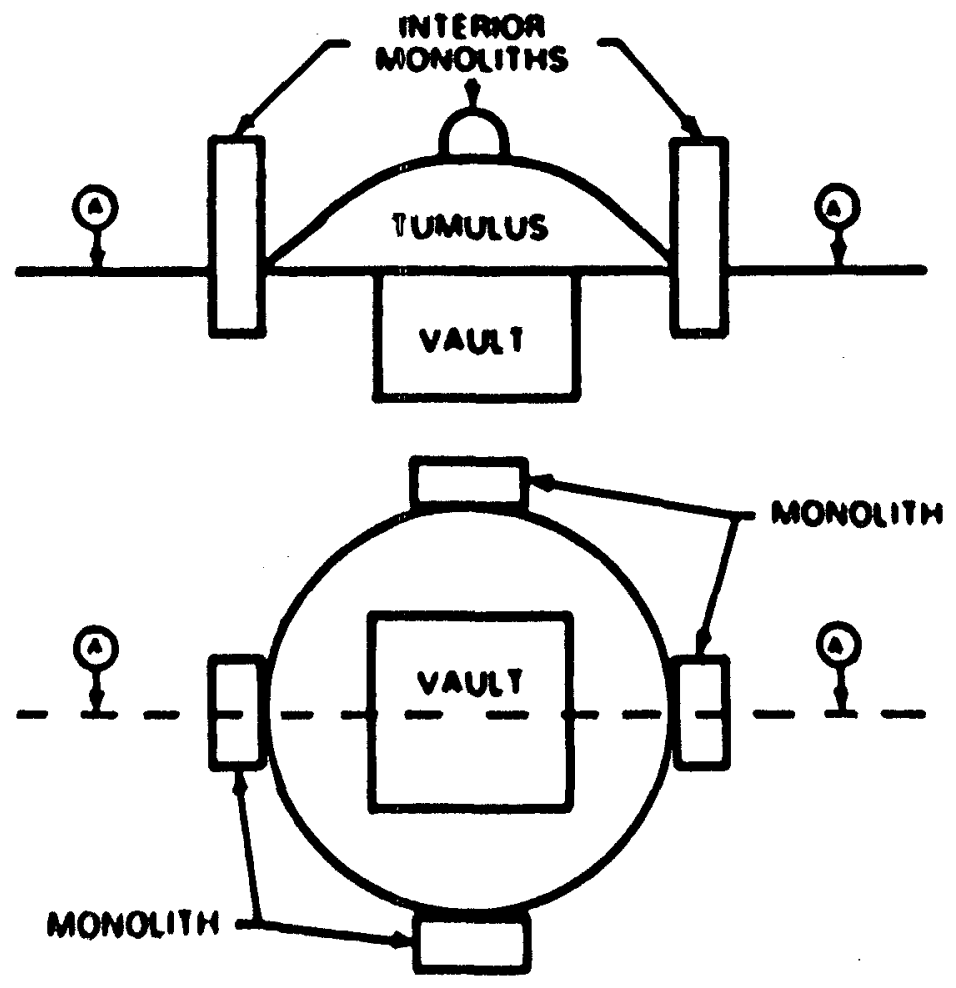

Plgure 4.2-3 Beccion and Top Viev of Tumulus and Intertor Monoliths
80040
1083 


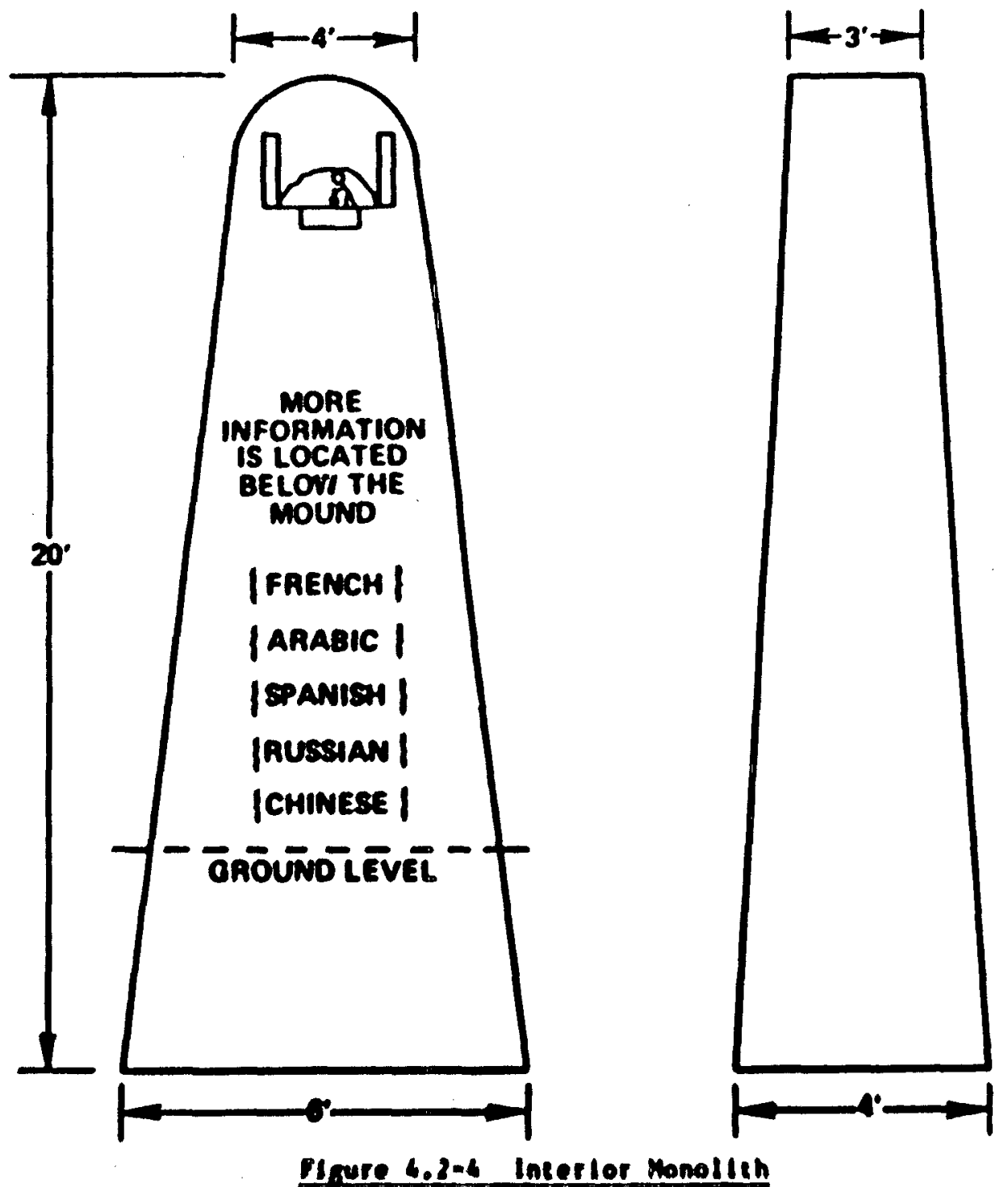

the oound to shown a $10 \mathrm{ft}$, eaking $1 \mathrm{t}$ within the range of other anclent

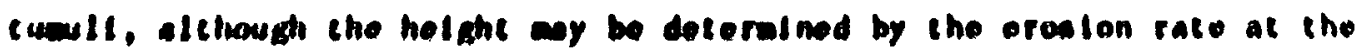
rapanticory elle.

Care whould be caken in diatingulah thase monollthe frun thowe marhing the pertocter. For this reason they should be dffforent in a number of r...

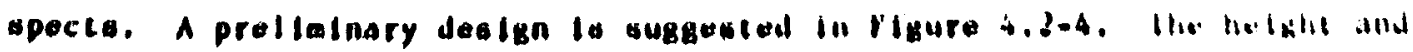

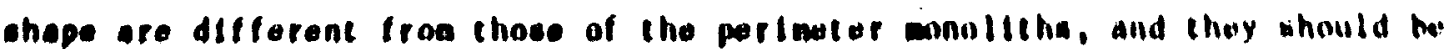

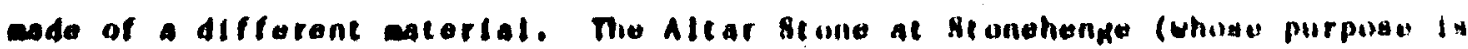
unknown) Ia arice example of the altentlon atven to componenty made if a

$$
80040 \quad 1084
$$


ditferent waterial than that wich was used in the bulk of the construction. (2(1) Like the perimeter nonoliths, they are tapered tor stability. The ditterence in the messages on these monoliths and the perimeter wonoliths are discussed in section 4.3.2.

There is a possiblitity that the saller size and tewer number of incerior wonoliths Increase the likelithood of theit being cartied off or destroyed. The fact that these monoliths surround an obviously non-natural pound of earth 18 going to draw atcention to that wound. Excavation of that wound probably would occur before the monollths would be noved or dasaged. Finally, the wonoliths are stil larger than the "twice human size- guideline for identifyIng materials likely to be rewoved to auseung.

Veult - The vault contalns the Level iv intornetion. The anclent world. however, has not left an overly wde celection of durable materials used for cexts - papyrus, clay, and stone. There are two cultures in the thar bast were witing has a 3,000 year higtory - Egypt and heopotenta. The oldest byyptian cexte are on stone; only lew framente of paprruo curvive trow the Uld KIngdun.(13) In mesopotanla, papptus did mot exist and atone was very rare. Architecture and witing therefore ullliged the comon batetialo of budbrick and clay. The earilest wtiling fros inis area is found on clay tablete of the semdet nar perted c. J100-xfou b.6.(70.79)

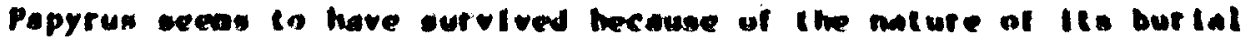
environent. The drymens of that ewvifoncent would be dupliteted in the

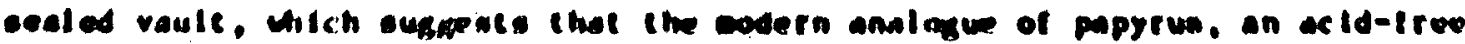

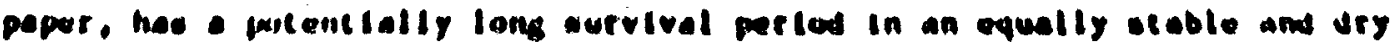

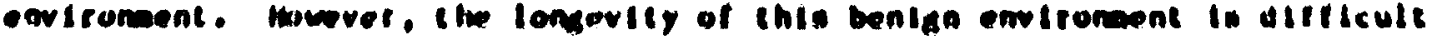
co entere.

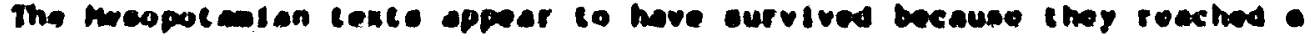

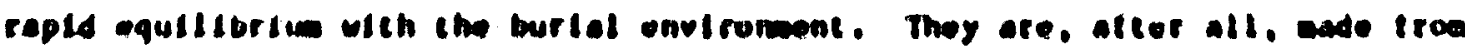

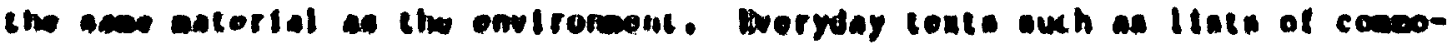
dicles and private and butinens lettere wre on untifed. but sun-drited

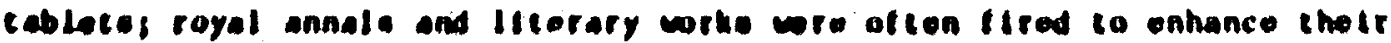
curvival. Hirod tablete are anch lite potsherdus they ay break but they are ctherviae axtranely durable. Mubleas in conservation arteo only atter the objecte liave been roeoved from the onvitroment in which they are in a atate of equilibritu, The durablitity of clay tablets is attested to by the 400,000

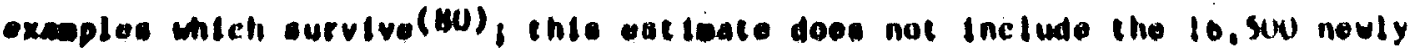

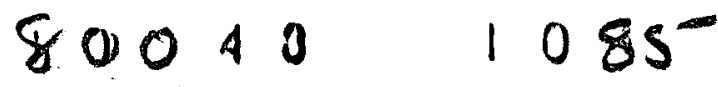


discuvered tablets and tragwents from the site of tbla in syria.(6l) It should also be moled that these tablets are tound lin burlal climates which would not be conducive to the survival of papyrus.

The archaeological evidence attesting the survivability ut stone has already been given in several places in this report. Stone and t Ired clay, therefore, appear to be suitable materials for the Level IV intormation.

The vault and its contents are the only non-replicated components ot the repository marker system. Unce opened, the vault no longer tunctions as an on-site warker. Most of the contents would eventually be removed to the future equivalent of a library, univetsity, or ouseur tor sate keeping and study. This would occur even if the vault wete initially looted. A parallel situation would be the Dead sea Scrolls wich were originally tound by a bedouin child.(82) The vault ohould, thetefore, also contaln a request that the Inforwation be translated into the languages in use at that time, placed on durable materials, and replaced in an on-ste warker. It that soctety considers the intorwation of suffictent interest, It Is Iikely to be translated and made avallable to a wider oudlence, nuch lithe the works in Ancient

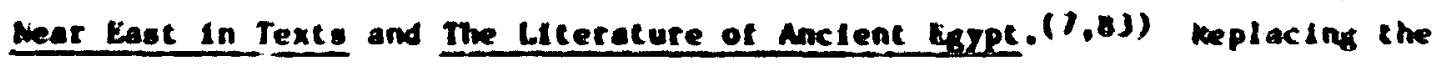
"updated" version on the atte is lless likely to be done. The society bay nut consider ti necessary to replace the fatormation, but the request aust be ade. It should be noted, however. that In this scenerto, the warker verves 1te purpose by aking the intormerion evallable to the public, and initiet int - new cycle of oft-ette Intormation tramefer.

\section{3 maresn mescht}

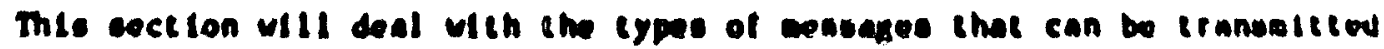

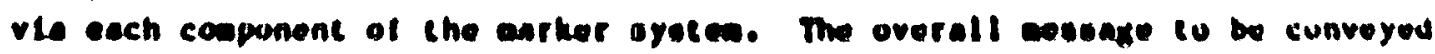

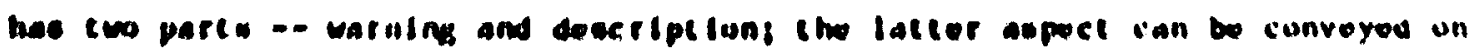

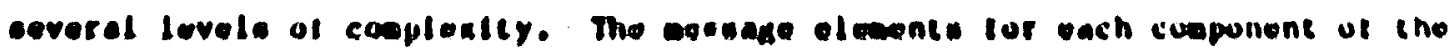
repostcory arking oyetos are discussed in eoparate oubsect lons.

\subsection{1 pertecter monolithe}

Kach anolith would be Inectibed on three atdes. Ieaviliz ono bruad wido bleak. Wy placting each anolith gu that the blank tace is turned tivards to

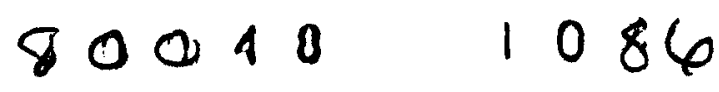


the repository site. the observer is informed about where he or she should be standing. I.c., outside of the repostory area facing the monolith. As mentoned earlier, the position of the monoliths defines the repository area.

The front face of the marker (FIgure 4.3-1) bears the warning of the slte and the siaplest level of description. In the top left corner is the hazardous materlal warning symbsl developed by the HITf. The syabol to the right of it acts as a qualifter, 1.e.. radtoactlve materlal. Thls line can be "read" elther from left to right or right co left. The syabol below it is patcerned

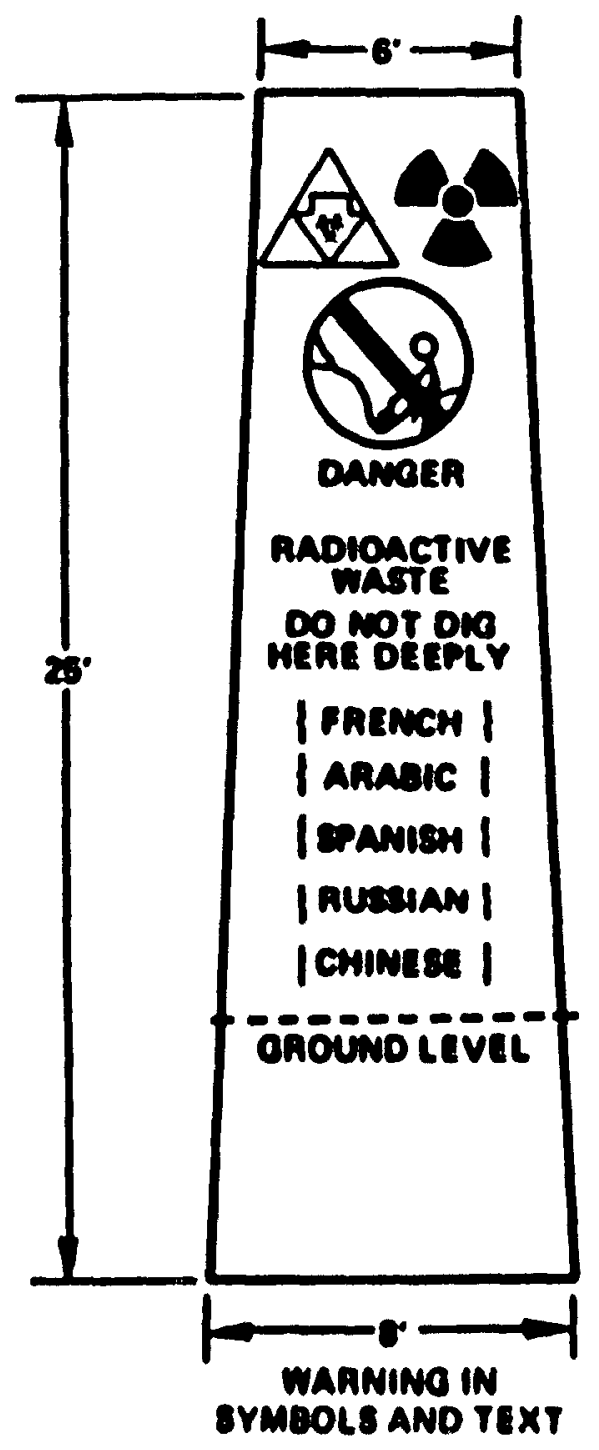

Plgure 4. I-1 Pertmater Monallin 
atter the international driving signs. It shows a human digking with ithe dram across it. (This may be Interpreted as that no diksing should be june at the stie, but since we cannot convey the ditierence between surtace and deep excavation in a fingle simple syabol, it is beter co cunvey the mure conservat (ve pessage).

The next $81 \times$ panels repeat this information in the six languages of the United Nations. The use of six larguages Increases che possibllity that at least one of thew will be recognizable to a numet ol prople and readable by scoe scholars. The wording is delibetately siaple in order tu fartitate its recognition. The inglish text reads "waxkR. RADIOACTIVE WASTE. UN WUT UIG DEEPLY HEKF."

This appect of the market is obriously woded on the kosetra stone. It

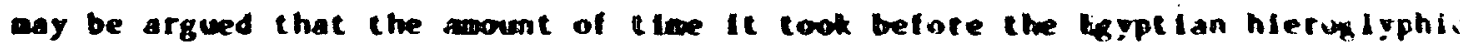
cext could be tead (nearly 25 yeats after the stome"s discorety) would mot be In time co prevent interfetence in the repository. This trmotes the iaportant fact that one of the languages was tecogntable and teadable at lie lare of

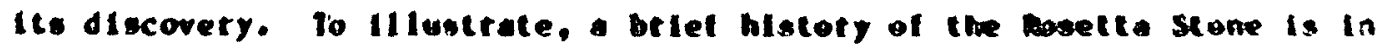

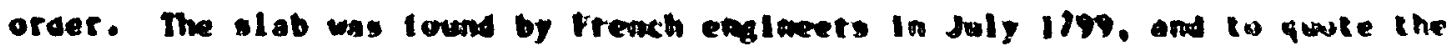

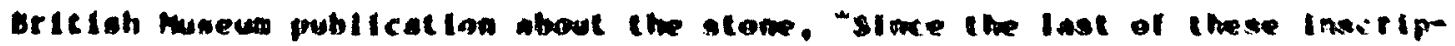

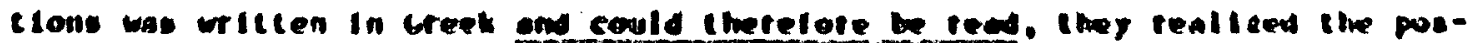

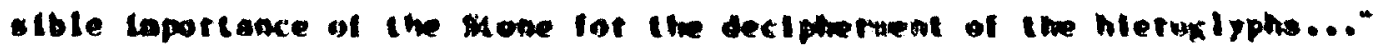

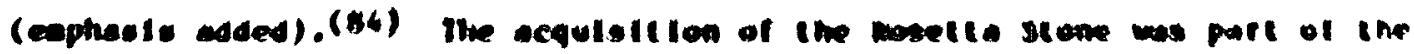

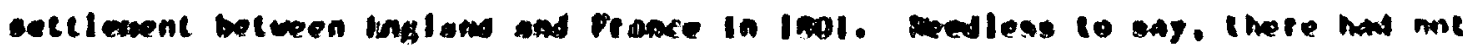

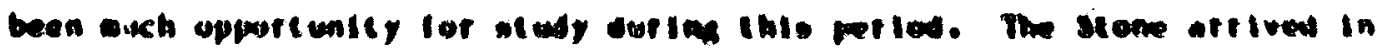

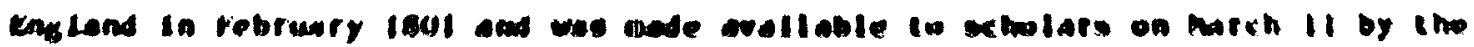

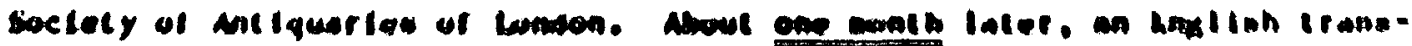

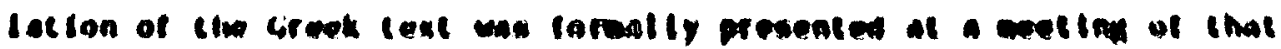
Soctery. (40)

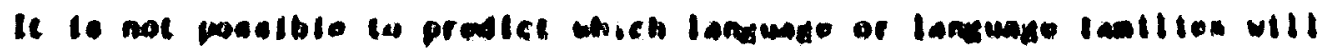

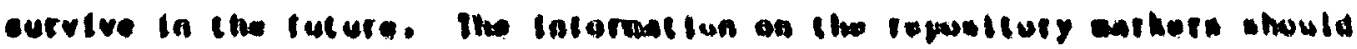

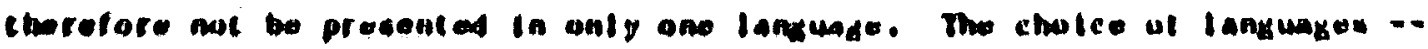

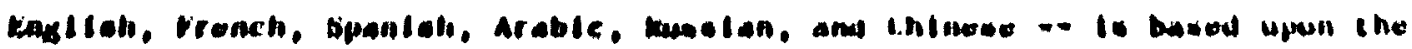

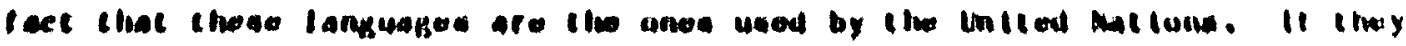

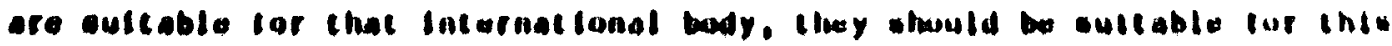

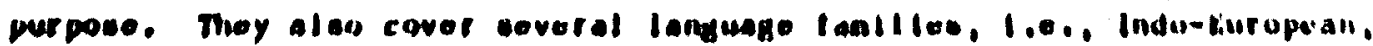
seitite, and litultic.
80040 
One side panel of the marker is devoted to a description ot the repository lin symbols, pictures, and figures. The derivation of a pictorial representation of wat was done at the repository site is not within the scope of chls repurt. Such a representation, however, should be included on this panel. In addition, diagrams can be used to show the areal extent and depth of the repository; an example, based on the wipp site. Is biven in tigure 4.3-2. The areal extent and the postitions of the perineter and internal monoliths are draw. The wonoltths are not dram in scale since they would not be visible. An arrow arks the position of the monolith wich is belny studied. This will help reconstruct the layout of the site even if several of the markers are gone. The earthwrk, If included, should also be show to indicate its contemporanelty with the reat of the systes. (for example, we know that the ceople at luxor once had two obelisk in front of it, where only

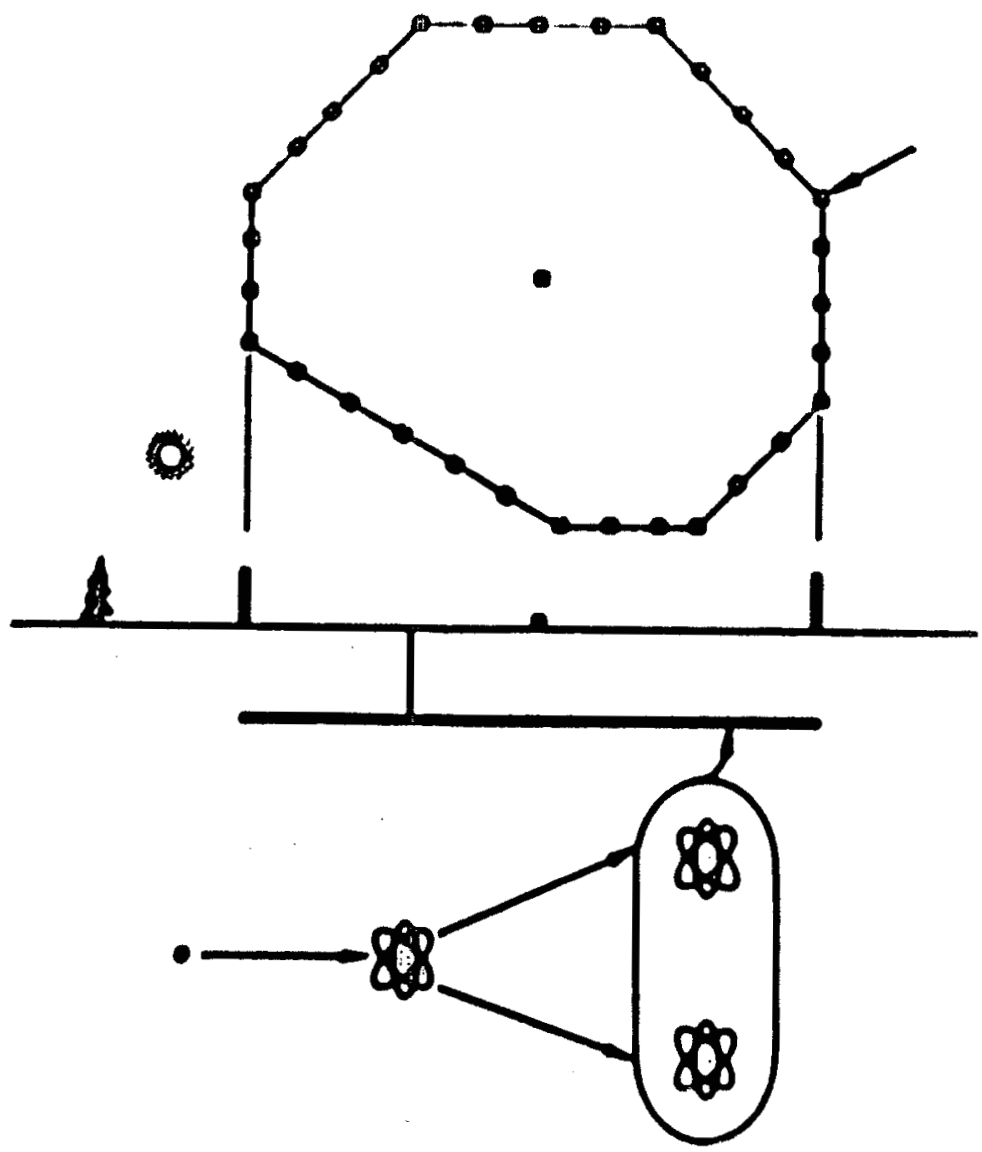

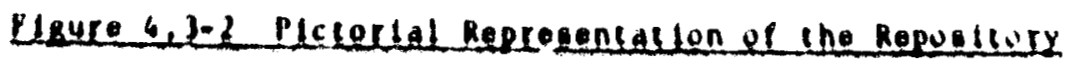


one now stands, because the temple is drawn on one ot the insice walls. $(85,80)$ it is not possible to put a line of unit length on the tarker and then show it on the figure - the ditferences in scale are too giteat.

below the top view is a cross-sectional view of the repositury. The sur. and a plant (here, a tree) define the ground level. The present design calls fur the monoliths to stand to a height of $20 \mathrm{ft}$ above the ground; this is approximately 1 percent ot the depth co the repository. The monoliths would not be imediately discernible it dram to scale, and that wuld deteat part ot the purpose of the plan. They are theretore strow out of scale in order tu be visible. The ratio of the widh of the stce to its depth shuuld, humever, be accurately represented. The figures in the center should be citcular ur triangular depending upon the option chosen tut the central earker.

un the button of this figure is a schematic representation of what is contalined in the repusitury. It shows a neutron striking an atum whitin then t1ssions. As shown, the tigure represents high-level waste: the disposal of spent fuel would be indicated by having the circle Include the atwa which fissions as well. This general tepresentation was chuen tor lts siaplicity and clarity. The large nubber of lsotopes which are found in the waste pricluden their reptesentation, ince they change in the (1.e.. The representation wold be Insccurate) and the repreaentation would be too epace-cunsualnd wile providing too little intormation. That level of Information is apprupriete tor the core complex level, not here.

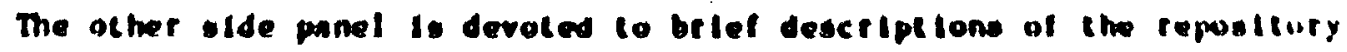
in teat. The rationale tor the use of oultiple lenguges and the ctoutce ut chose langunges has been discussed above. The teat bhould be hept imple.

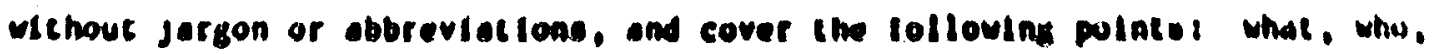

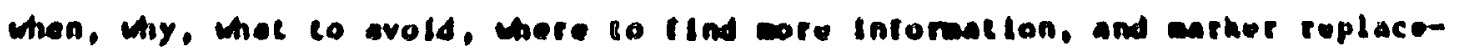
went. The quention of "hov" requitres 200 copplex on anewer to be Incliudod an chis arker, but would be included in the vaule.

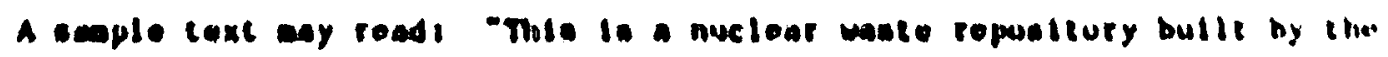
Untead stalea sovernment in - The arod at the ropostigary is by

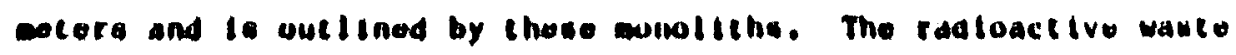
10 burted ankind. In not drill

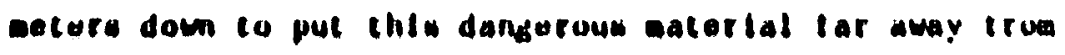

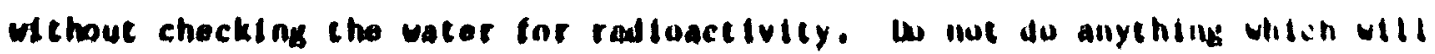

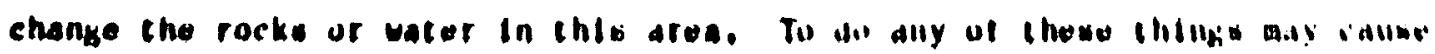


exposure of hunans to radioactivity which gay result in cancer. More Inforation is located under the hill in the center of thls site and in governaent librarles. Do not destroy this marker, but replace it by using long-lasting materials and languages common in your tine."

\subsubsection{Earthwork}

As mentoned above, the eartmork can only convey a limited abount of information, 1.e., sowething is here and it is hazardous. The first is conveyed

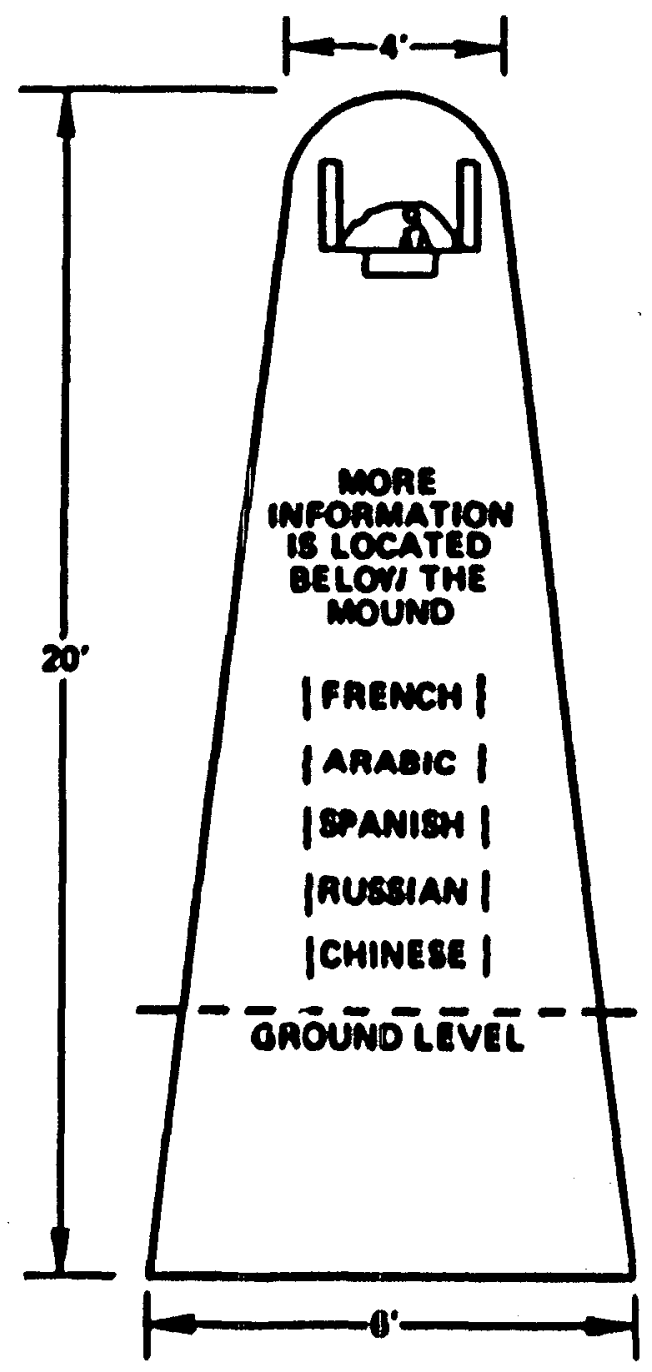

Plgure 4.3-3 Interlor Monalith

80010

1091 


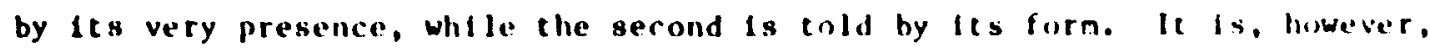
the one component which is a sutable vehicle for conveyinx a messipto to remote sensing devices. Suggestions may be made for possible inclusions in the earthwork to enhance 1 ts detectability (e.R. magnetite), but these have no archaeological precursors.

\subsubsection{Interior Marker}

The bessage borne by the Intertor monoliths is siople - - nore Information Is located under the mound. The Interlor conolith (Fipure \$.3-3) does not bear the hazardous material warning syabol. since there is mo danger fron Investigating the vault. The IIgure shown, however, specifles that the area to Investigate is below the wound between the interlor monoliths. The oultiIIngual Inscriptions explain what is burled; a sapple cext In Finglish reads "More Information is located below the anound".

\subsubsection{Vauit}

The vault contalns the level IV Inforation and will nut need to be effect Ive unt 11 all other of talte archlloal Information is Iost. It the ite location is lont. The perfoeter monoliths will cerve in link the concept of "muclear waste hurlat" and "burtal at thls ofle". It ints has occurred, coctety will recover the technolan to breach the vaule before it resnvers the

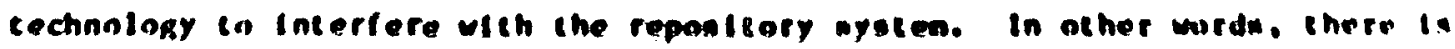

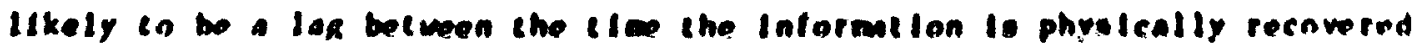
and the cles interterence could eccurs phis lan would allaw the potent lat tor the inforastion in be defipliered and the provent Interference. 
The approach taken in this report is that the likelihoud ot human incer-

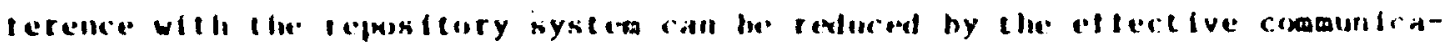

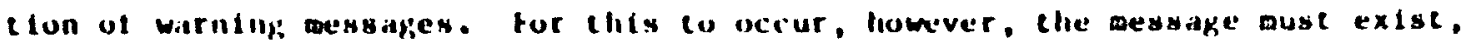
be detectable, and be understood. A vessage can exist only after lt has been ascertained what should exist (bessage definition), where it should exist (nessage location) and how long te should exist (tessake survival). There are tuur posstble levels ot intormation tor the sessage:(t)

- Level 1: Actention-getter, i.e., someching is here.

- Level Il: Attention-getter and warning, 1.e.. sowething is here and It is dangerous.

- Leve1 111: basfc information, l.e., what, wo, when, why, what actions to avold, and were co find wore inforation.

- Level IV: Pull record of Inforoution, 1.e., plans, draulngs. enviromental iopact statewents, etc.

Archaeological daca Indicate that the ut 1 ilty of a Level I ecsage without any ascociation with a highet level wessage maj be doblows, wile level iv data appear to be carried only by witten docubents which gemetally do not nccur at a sarker sice. Incarporating all low Ievels ol Intoration in the tepusitory

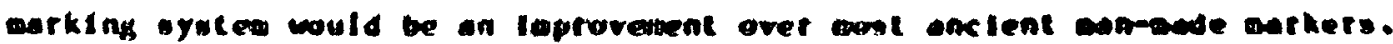

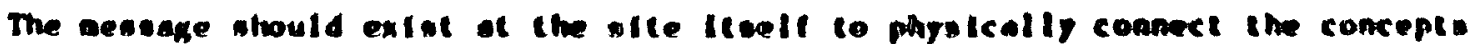
of "nuclear wante burial" and "butial ot inis ste".

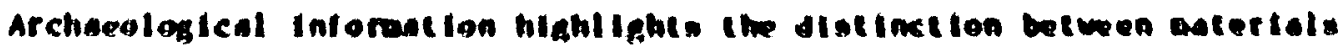

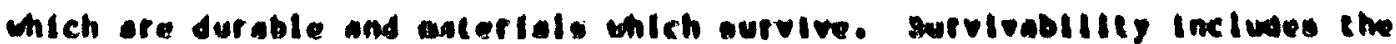

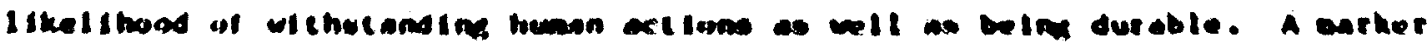

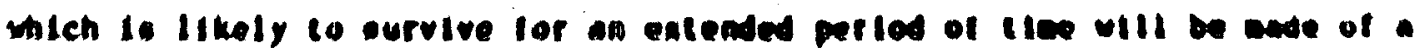

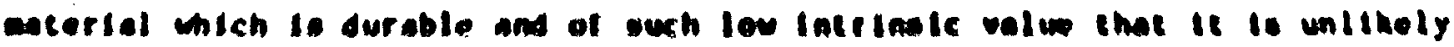

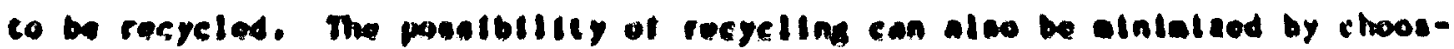

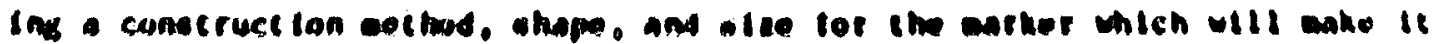

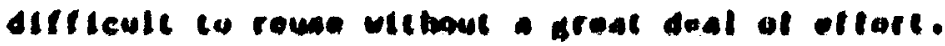

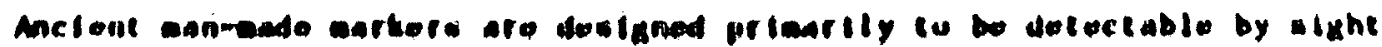

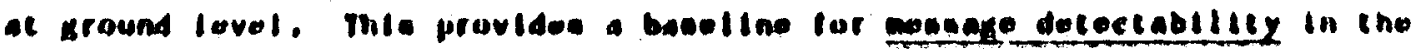

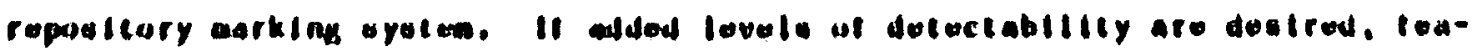

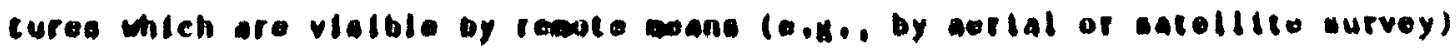

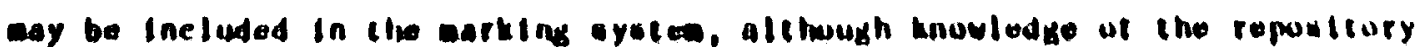

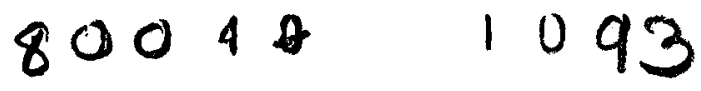


and its contents at this distance will not affect the functionitg of the repustory system.

The third factor in the mirking system design Is message comprehensib!!1ty. The message can be conveyed by three different means -- symbols, pictures, and languages. Archaeolnglcal data Indicate that the hlgher levels of information may only be able to be carried across great changes in time and culture via writen languages. The repository warking system should incriporate all three means of conveying a message, and should ut llize a number of languages to enhance the likelthood that at least one of thea will be recugntzable to a number of people and readable by some scholars. ThIs report suggests using the $s 1 \times$ languages used by the linted lations.

The preliminary arking systeo design presented In this report has three possible components:

- A series of conoliths delineating the overall extent of the repository, or the repository plus buffer cone.

- An opt tonal earthork In the forn of the hacardous accerlal warning syabol (included in the marking systew if visiblity or detectablity at great distancs, e.g. satellite, Is desirable).

- A central arker containthe the aost detalled level nf Informeton. The Intormation lo not lonediately ovallable to an Investigator but Is readily accessible.

Each of these cooponents has an amslogue In an anclent anmode aarker vhlch han already survived for at least one thousand yeers. The Inforantion aboul ofx enclent ma-ade enters is sumertaed to provide the backiround upon which the desian in beed.

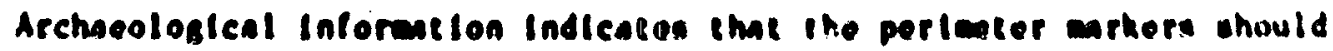
have the lollowing charecterifetiest

- They ahmuld be conolithic. One plece construction ellatinaten a atertale Intertece between the bondlng agent and componont partw. a

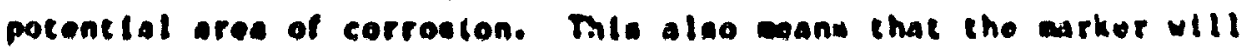
requite no active anterenance.

- Ther cliould be opaced so that the next monolteh in oach direction can be eeens 1.0. the patcern delineating the ite ta recogntabite at Bround level.

- The conoltehe should be ade of a hard, conpact, non-brittlo. mon-porous, and relatively homgeneous stone. Motal is two eastir

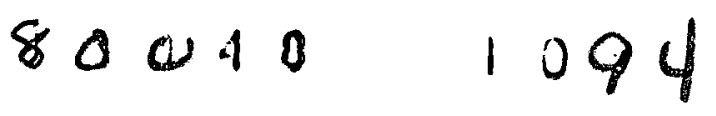


ant lan trequent ly recyelind to use is i morker whleh ihould survive for cextended perlods of $t$ ime.

- They should he megalithic. An unusually large slze or shape for the marker will minimize the ease with witch te could he removed and reuked in another structure.

- The monoliths should carry the first three levels of Infurmaton (atcention-getter, warning, and brief descrintion).

The perimeter monoliths will be sufficlent In nubber and carry enough Information so that the areal extent of the repositnry can be ascertalned even if some of the monolths are removed. Inscriblng the markers with symbols, plctures, and Informat Ion in multiple languages will anke chls set of aurkers more Informat ive than the large maforty of anclent monuents. Sabple draw ings and texts are provided in Section 4.3.1. The perlacter arkers. then, contatn enough information to jnin together the concepts of muclear waste burlal" and "burial at this st te".

The earthork can carry only level I or Level II Inforation (1.e.. attentinn-getter, or attentlon-getter with warnlag). Its priar fumitnn will be to call attent Ion to the ste from great diatances, such as those n! aerlal or satellite aurveylng. Whether or not this Is a requistice part uf the final repository arkilig syatew design Is a dectsion mich rests with the hump Interference Takk Porce.

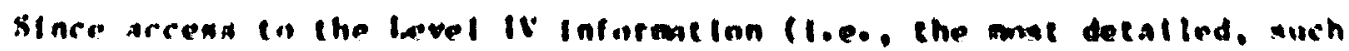

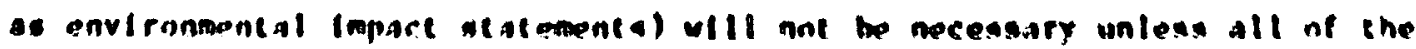
offatie archival recorda have heen destpoyed. Inl I Information need nut be lonediacely avaliable en an inventigator. For the Intortor marter. the infor-

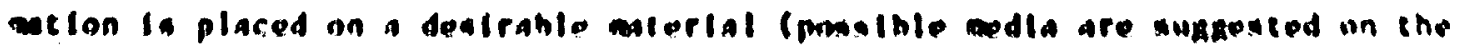
banta of archaenlagleal daf al and confalnod In a whallmuly burled valle. The location of the vault is marked (and protectod by) a mund of parth which it.

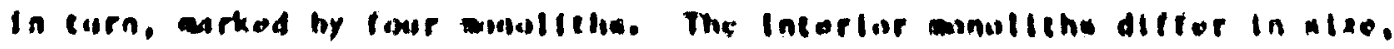

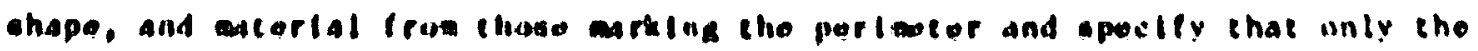
arat In betweon llieg should be invost lgatod. 
1. "Proposed Enviconmental Protection Agency Criteria for Radioact Ive Haste, - Untced States Finvironmental Protection Agency, is Federal Register. Section 221, November 1978.

2. Rocklin, G.1., "Nuclear Haste Disposal - Two Social Criteria," Sclence 195 (1977), pp. 23-31.

3. U.S. Department of Energy, Statewent of Position of the U.S. Departaent of Energy in the Matter of Proposed Rulemaking on Storage and Disposal of Nuclear Wastes (Waste ConfIdence Ruleasking), DEINE-0007, Apr II I9s?.

6. Givens, D., "From llere to Eternity. Commulcating with the Distant Future," University of Washington, 19hI.

5. Salth, N., "Roman Hydraulic Technologr." Sclentifle Maerlcan, May 19ik, pp. $154-61$.

6. U.S. Department of Energy, wuts Propran nfflce. Murts Propran Crilerla for Ceolosic Disposal of muclear vaste - site Perforaance Criterta. DOE/RTS-33(2). 1981.

7. Pritchard, 0.B.. Ancient near Eotern Texts. Princeton, 1969.

8. Kewberry. P.E., El Beraheh 1. Londnn, In96.

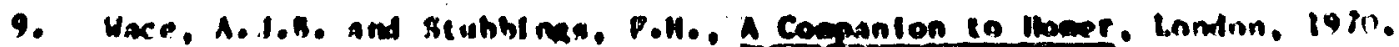

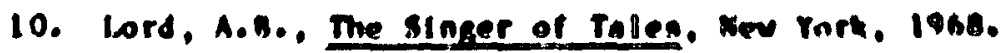

11. Fakhry, A., Tho Pyrades, Chleakn, 1949.

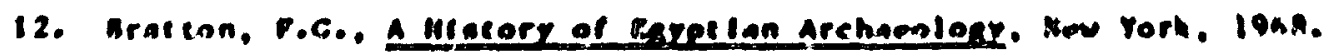

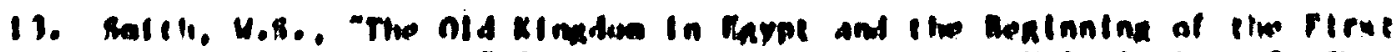

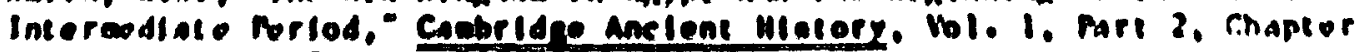
14. Cantridap 1971, pp. T68-Jit.

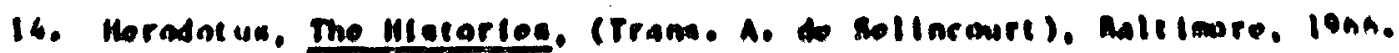

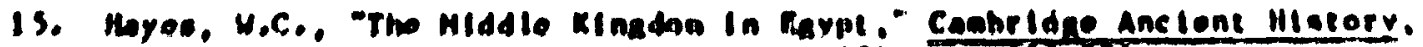

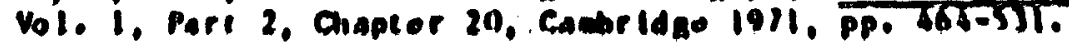

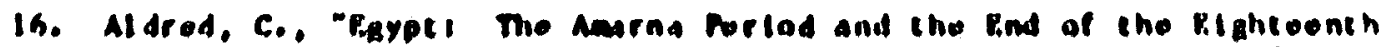
Dynasty." Ceabridne Ancleat Uletery. Vol. 2. Part 2. Chapenr 10.

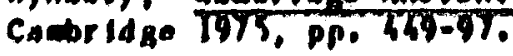


17. Faulkner, R.0., Egypt: From the Incept ion of the Nineteenth Dynasty to the Death of Ramses III, Cambridge Anclent Hlstory, Vol. 2, Part 2, Chapter 23, Cambr 1dge 1975, PP. 217-251.

18. Cerny, J., Egypt: Frow the Death of Rames III to the End of the Twenty-First Dynasty," Caabridge Anclent History, Vol. 2, Part 2, Chapter 35, Cambridge 1975, pp. 606-657.

19. Hassan, Sellm., The Great Sphinx and 128 Secrets, Calro, 1953.

20. Atkinson, R.J.E., Stonehenge, London 1956.

21. Bur 1, A., The Stone Circleg of the British Isles, New Haven, 1976.

22. Hawkins, C.S., Stonehenge Decoled, New Tork, 1965.

23. Renfew, C. Before Civilization: The Radlocarbon Revolution and Prehtstortc Europe, New Tork, TST3.

24. Hawkins, G.S., "Stonehenge: A meolithic Cooputer," Rature. Pol. 202. 1964. Pp. $1258-61$.

25. Howkns, 6.8., "stonehenge Decoded," Eacure. Do1. 200, 1963, pp. 306-08.

26. Ackinson, R.J.C., "Decoder MIsled," Nelure, Dol. 210, 1964, Pp. 1302.

27. Atkinson, R.J.E., Koonshine on Stonehenge." Antigultz. Vol. 40. 186h, Pp. 212.

28. Hoyle, F., "speculation on stonehrege," Aatleuitz. Pol. 40. 19h6. Pp. 262-76.

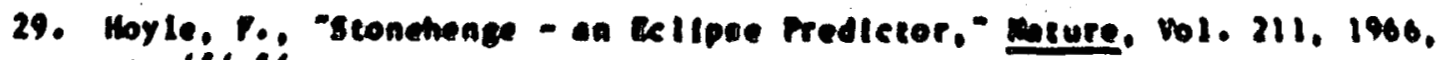
Pp. $456-36$

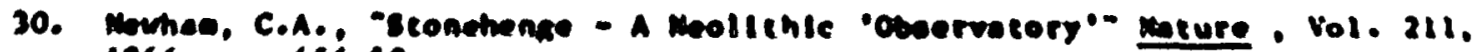
1966. Pp. 456-58.

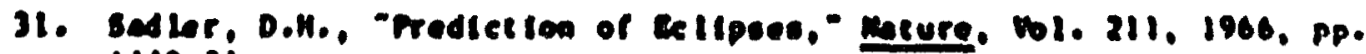
$1119-21$.

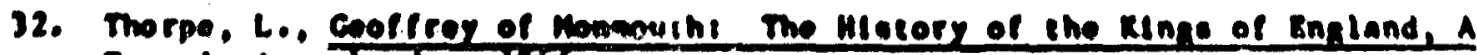
Tranalation, London, 1886.

33. Datel, G., Nergltehs in Heterz, London, 1972.

34. Crimall, H.V., Folklore of Prohtetorte stee in Dritein. London, 1976. 
35. Hawkins, G.s., Anclent Lines In the Peruvlan Desert: Final Report for the National Geographic Soclety, Cambridge, M1, 1969.

36. Isbell, H.H., "The Prehlstorle Ground Drawings of Peru," Sclentifle American, Vol. 239, 1978, pp. 140-53.

37. Broccker, H.S., Kulp, J.L. and Trucek, C.S., "Lamont Natural Radlscarbon Measurements," Sclence, Vol. 124, No. 3213, 1956, pp 154-65.

38. Ralph, F.K., Michael, H.N., and Han, M.C., "Radiocarbon Dates and Reallty," masCA Newsletter, Vol. 9, 1973, pp. 1-20.

39. Kosok, P., Life, Land, and Mater in Anclent Peru, Long Is land Ini versity Pres8, 1965.

40. Kosok, P., and Relche, M., "Anclent Drawlings on the Desert of Peru,Archaeology, Vol. 2, 1949, Pp. 206-15.

41. Morrison, T., Pathways to the Cods, New Tork, 1978.

42. Willey, C.S., Introduction to Amertcan Archaedogy, New bersey, $19: 2$.

43. Rove, A.H., and Menzel, D., Peruvlan Archaeolong: Selected Readinga. Palo Alto, 1967.

44. MeIntyre, L., Mysiery of the Anclent Macen Lines," Katlonal Coagraphis. Vol. 147, 1975, pp. 116-2A.

45. Davla, R.t., and WInslow, 8. "Glant Cround PIgures of the Prehlstorle Desert.," Proceedings of the aderican Philosophical soclely. Vol. ing, 109, 1965, Pp. 8-2T.

46. Creenasn, R.P., serpent Bound, Coluntur, 1970.

47. Putnen, P.W., The Serpent Hound of Onlo,- Contury llluserreted Monthly Mogezine, April IA99, pp. Bl1-B8.

48. Sqular, E.C., and Davis, H.H., Anclent Monueents of the Mlenlenlppt Velley, How rork, 1848.

49. Hocloen, J.P., "The Creat serpene Moupd,- Acerlean Anileunrtan and Ortentel Journal. Vol. T, 1885, pr. 44-41.

50. Willowghby, C.C.. "The serpent Mound of Adane County, Ohlo," Acorlcan Anehropologink. Val. 21, 1919, Pp. 153-6).

31. Travloa, J.. Pletorlal Dletlonary of Anclont Aehona, Now rork, 1911. 
52. Rosstter, S. Greece, The Blue Gulde, London, 1973.

53. Dow, S., "Andrews of Cornell," Cornell Alumnl News, December 1972, pp. 13-21.

54. Robertson, M., and Frantz, A. The Parthenon Frleze, London, 1975.

55. Bouras, C., "Test Ing TIm for The Acropolls Monuments," Scone Industries, Vol. 14, 1979, pp. 22-26.

56. Me18gs, R., and lewls, D., A Selection of Creek HIstorlcal Inscriptlons to the End of the Fifth Century B.C., Oxford, 1969.

57. Secend International Srapostue on the Detertoracion of Bullding Stones. (Athens, 1976), Athens, 1978.

58. CeI1, H.E.. The Great Wall of ChIna, Nev Tork, 1909.

59. S11 verberg. R., The Great Hall of ChIne, Rew Tork. 1965.

60. Fryer. J., The Creet Uall of China, Iondon. 1973.

61. Neechav, J.. Sclence and Civilleation In ChIna. Canbridge, 1954.

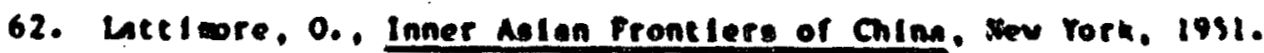

63. Ine, P.. The Purple Barrier, London. 19sn.

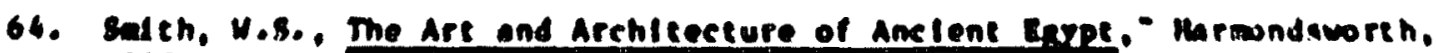
1958.

65. Clab. P.V.. The Dor Poople. Ithace. 1969.

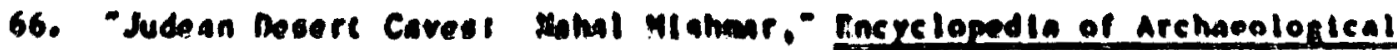

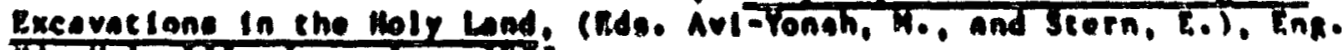

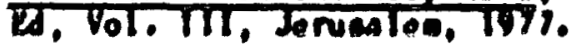

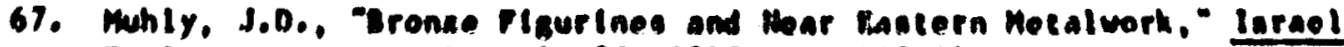
Exploration Journal, Vol. J0, IOAO, pp. 14A-61.

68. Bass, G.P.. "Cape Colldanyal A Droare Age entpureck." Transactlons of

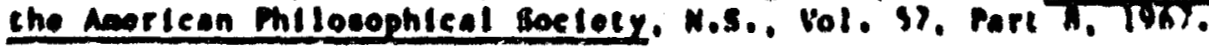

69. Plenderletth, H.L... and Vernor. A.l.A.. The Coneervation of Ant lqutrtes and Works of Are, Oxford, 1914.

70. Art and Archaeolosy Technical Abecracts. Inatitute for Pino Are., Now

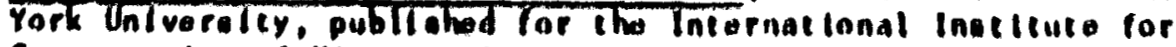

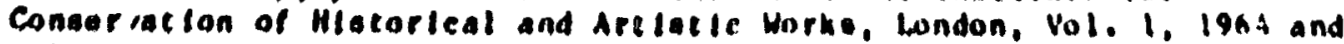
aubaequent yasra. 
71. Thompson, D.L., "The Inst City of Ant tnous," Archaeology, Vol. 3:, 1981, Pp. 44-50.

72. Lewn, S.2., and Carola, A.E., "Scanning Electron Microscopy In the Di agnos 18 of 'Diseased" Stone," ScannIng Electron MIcroscopy. Vol. I. 1978, pp. 695-704.

73. Helken, G., "Pyroclastic Flov Deposits," American Sclentist. Vol. ni. 1979, pp. $566-71$.

74. Bateman, C.A., Cravford, V.E., Dales, G.F., and wa fewskl, L.J.. Preservation and Reproduction of Claz Tablets and the Conservation of Wall Paint Ing8, London, 1966.

75. U.S. Department of Energy, Final Enfironmental Iopact Statewent Haste Isolation Pllot Plant, Der EIS-0026, October 1980.

76. Browing, 1., Petra, Lonton, 1974.

17. Downan, P.., Congervation in Pleld Archeolocy, London, 1970.

18. Prankfort, H.. "The Last Predmatlc Perlod in Labjlonia, Caebridge Anclent History, Vol. 1. Part 2, Chapter 12, Cabridge, 197, pp. T-92.

79. Oppenhe 10. A.L.. Anctent regopotabla, Chirago, 1904.

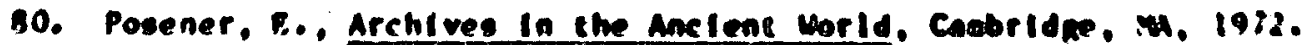

B1. Matchlae. P.. "Tell hardikhs The Archive and Polace." Archacolest. Vol. 30. $1977,0 p \cdot 246-51$.

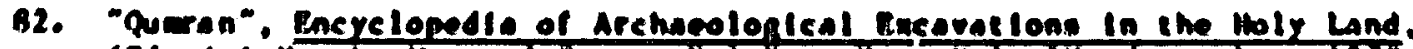

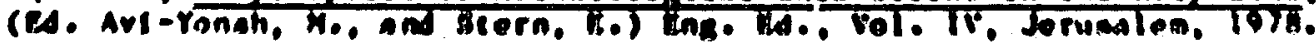

83. Stepagn, W.K., Fulkner, A.n., and Uente, H.F.. The Literature of Anctent Equet. Haw Hawn, 1973.

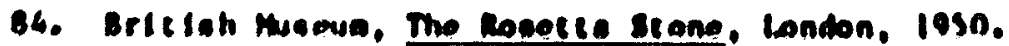

85. Murray, M.A., Esyptian Tenplen. Landon, 19J1.

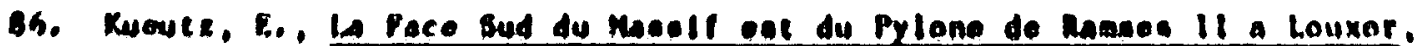
Catro, 1911. 


\section{DISTRIBUTION LIST}

Aclass meank AN INC

4 s. BuRGess

Q. struate

AlanuA Detr or ENangr

CAMIRON MCDONAIO

Alamama state ctococke sunver

THKORNIONI SAIMIRI

alled centan muctean stervets

P. Howat RGTR

Als-cratuates

Calnick 1. Sor over

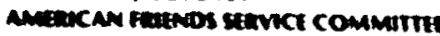

WLLIAM RE YMOTOS

AMincan muculan insuntixs

Dotru shrman

Aniacan minosomical associnanom MONN OCONAXS

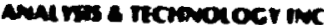

I. MAROUR

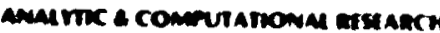

$\rightarrow$

D. sainar

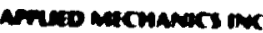

nem a nulliams

Accomm marromat eaconator

Ae Vin fi BnN

crrman hateriton

1. mow andi) aftill

C. I. austers

MARTE vit!

Manton 8 stesmatis

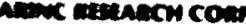

M. P. maninta

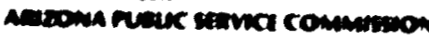

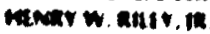

Anterna state unmentr

Pact Kenaum

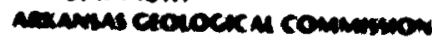

WHIJAM V UMA

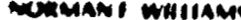

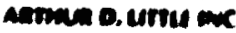

Amrit cateria

chames a isangr.

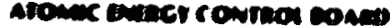

1. waskes

srome tancer r ounch are

movenum(a)

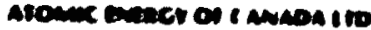

M. O. ILth

anis crumat

- parcane

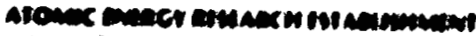
rimana

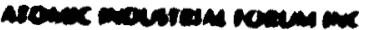

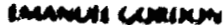

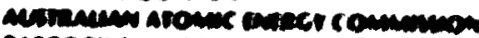

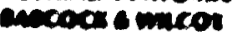

monmalicy wances

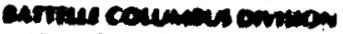

cown in mecrowats

wetert mans

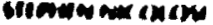

occmas a crame

Mandest ralls

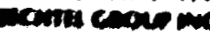

torousts sale

orow c canisu

D I exand ar

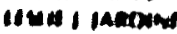

a c expmelem
I IURNAT

C NUI VIPARA

RIC HARI)I I(N)TII

eichill mational une

(ARAIUI PALAC.

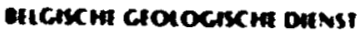

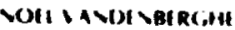

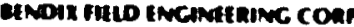

BHi CRAHAM

chartss a jonts

HONNC. PACIR

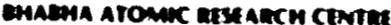

- Macinoras

- I monas

quar s valch

M. Nont Roavson

cotinc enconatiance ano construcmo comeravt

- c can us

outru srsmamanume

110 oat iva

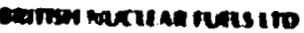

- Inias

Goomenaver wational uncation

(ARU11 and)

ixonatsi ciant

M DABrt

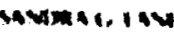

- w Itiv

mile ano

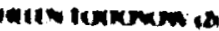

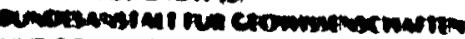

Ono movitoria

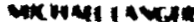

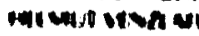

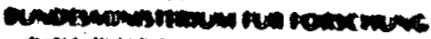

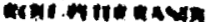

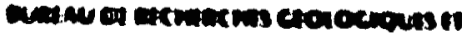

cominitias

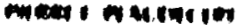

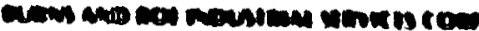
wion watos?

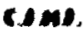

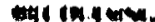

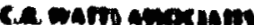

1teren waits

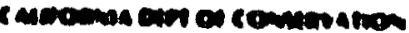

ment avenarte

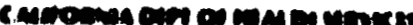

encrate cotis

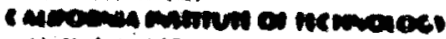

itces 1 antil

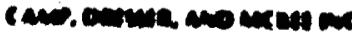

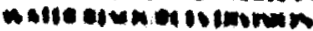

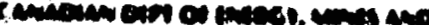

Amorem

a minara

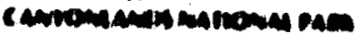

vite terest

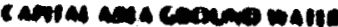

conituraban sominime

a Ilece at a

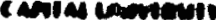

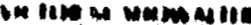

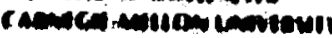

Hawe new

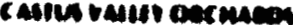

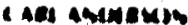

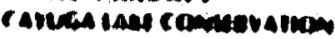

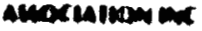

11. Butitit
CENIRAL WASHINCION UNIVIRSTI

IR III) ItWIRU

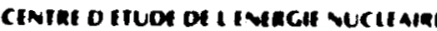

RI D PIRIVAS

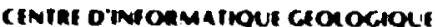

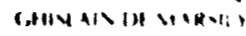

Cosinc

I (x) Allivit a it 11

Crem-nuCetian sistzus onc

RUES I if "l

Cimans associatron rom youndo ewecy

IR Avitallis

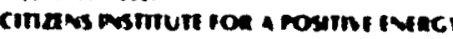
noticy

livoxt 11 (D)

cuate convensm

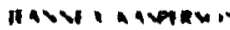

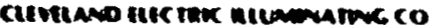

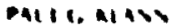

cononabo cronock a sumbro

kinn nex:1

conom 400 sc noon on wave

in vin III

comat bevi sumce counce

chomit thom inn)

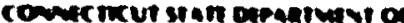

minuserences

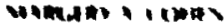

consingabou counct on noam

canouman

inv vilue

coner ascotions

nove in

conerens $n$ aco

11. init

cominats

internetias

cemeat unistimson

wen nawt.

Inton or and

in tw ontomits

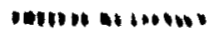

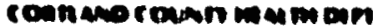

in it it

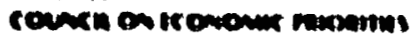

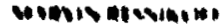

crend endess verute

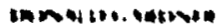

ant

ntan o ative

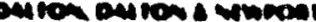

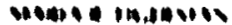

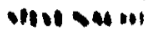

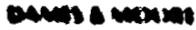

enlos tomatis

Din aith

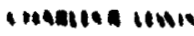

11 I Leplinat

banmomen comun buc thanesen the

ins insume

ane bemets

Drwetilsurt

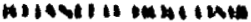

nite ativel

t int H Hacter

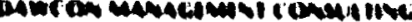

mente

thabli a nevilu

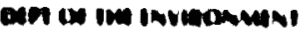

I It 11 .

\section{0}




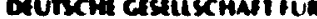

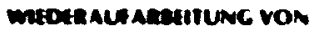

HAMA WEIIMMADR

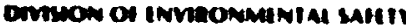

arsench

MARTIO VARAMII.R

orvison of movsiman wrcana 4

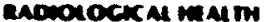

mat s sloxhy

pano fincenters and consthucions

AIN Bu MI

oud unmensin

IHOMAS DALIS

ounin croscince cone

whe cetritit!

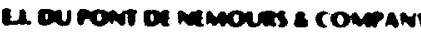
Donato I. contros

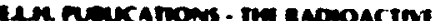
ircuance

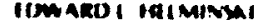

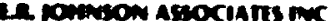

t nomson

C1. Rominson

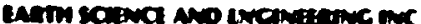
IOU Bankin

east Canouna unviart

bremetv 8 maner

east teanowa sat unmearr

Maknall a, SNotin

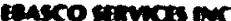

Tean saltim

RARMOND H. YNim

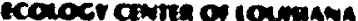

noss vonk int

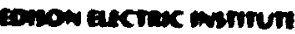

a.1. L stavomo

cos mercian me

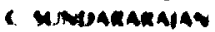

C. 4 Copane me

croped living

M. o. arcegrmas

cance ant

lo mails

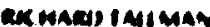

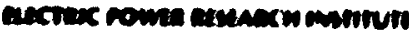

CHam erat

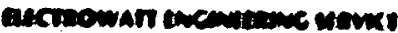

ov vara

arex

A. ก num

anim ariant

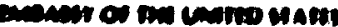

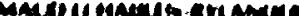

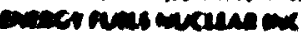

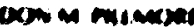

mincermes

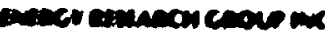

Manc congumin

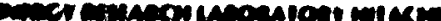

$\rightarrow$

meroto mata it

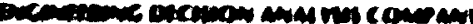

(u)

connerow was

cumoemmint Camare

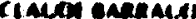

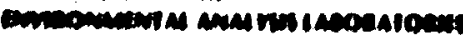

cons

Hom divathe

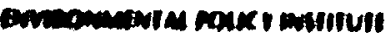

Jabo as crack

cero mat in

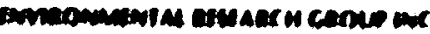

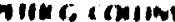

INBINUNMANTAL RESOUACIS MAMACEMINI inc

R(B)AII) AI AVIXINPI

munosmane coneran.

Roxar c. ANTRE)

on maivis

en countr tminomunta

MANACSMEN COUNCA

nate senvibr

carec wrstian anc

i CARI stiop

Marr alkwe

truon muculan bano commant bx

atrat a compray

ecoces server

n e neter

notal I vernit

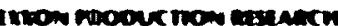

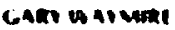

inal

utrotanton.

im ron ano aveocantes on

vant is earm

ine erromer

cons a warado

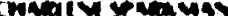

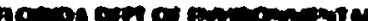

tornatoon

Anvin tow onts

porat mumbe o rectumest Kontent a suctio. in

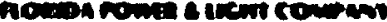

Insms a rowmento

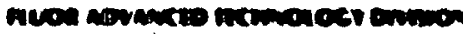
contr cur cum

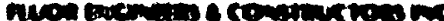
anveromit on tom

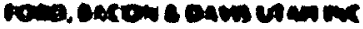

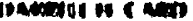

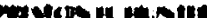

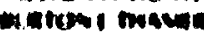

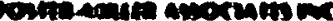
inimat past

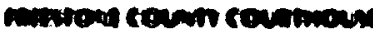

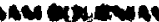

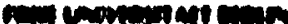

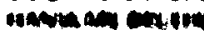

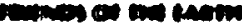

un wore bur

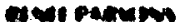

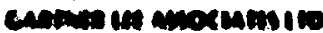

armen inger

crimina atones comanes

achab o cacerase

ot 4 and

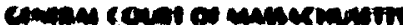

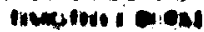

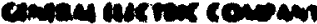

cretion it nem

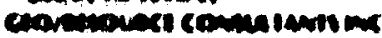
arimo an.

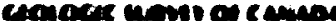

atretes obing

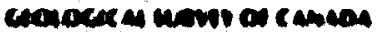
amin nim

unte cill

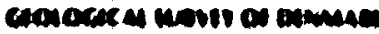
1 indusen

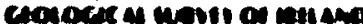

mixul to nat

comprac a wowe a naves Mabibin. Me!

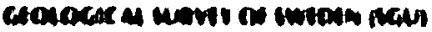

- A) Artan cencelown consel finc caove

11, 41 414 i1, 45

CeOncel instituti of HCMivotocs

VIIWIN I ARIIK

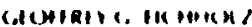

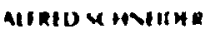

CHARISI WIAIER

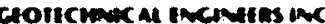

Richat) on Havbidi

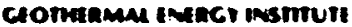

connin! IIN

cronmank mome comans

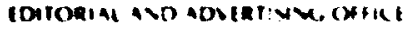

cromons

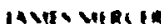

crevantown tedinos scroos

mata a Alum

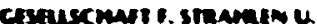

unditronscinac uan.

mercaverex

etevabsedv

mavs 1101

"Irrenta

itaverien

crise min enc

mover rat ro

engercomoning

nativ! III

cropen manes the

cunet t ent It

contin Ascritrs

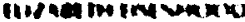

ineswe a niple

cinnce

Irontid w in wit

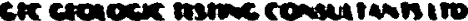
amo mory

cuat notherate one

munates ome

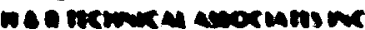

nntisen monv

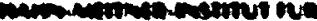

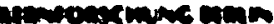

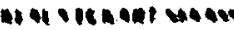

mues aro arements

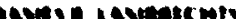

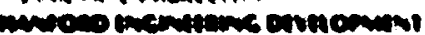

caronaters

ateral to chatis

atmet in mo

Q I nemt

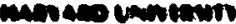

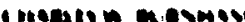

bars n maste

Q ervand wive

mencentes

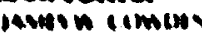

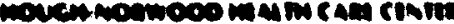

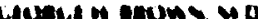

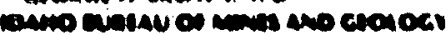
14at at andl

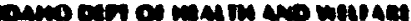

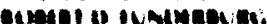

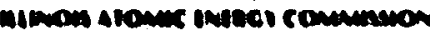

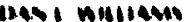

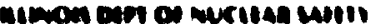

wh tew antin

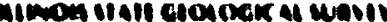

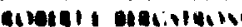

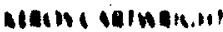

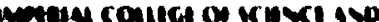

icrmaposi

- clatrair 
momana crotocec al ramit!

MalkIII BKa.S

monara chavients

I Imosti

"HAVIN " WI RR W

bormut on mathanence

niavi anikil/

Aisis at iny

t culla

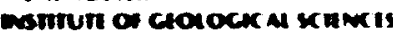

Win a conpmaty

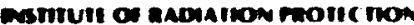

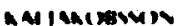

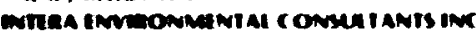

- I narux. IR

compt antum

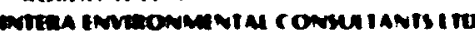
I cmat

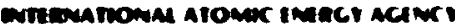

Irintlin inewe

InANa a curaka

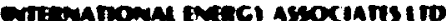
artia a irons

motinamomal butacr sustems comp cows a comits

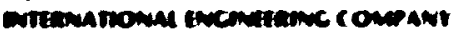
anc

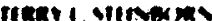

Mat IAs Aws

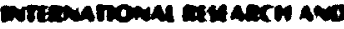

cracustom

a DANC)

oma cencora umv

ocranol cax *h

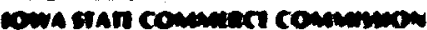

contat inxist

cres crant cumbur

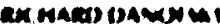

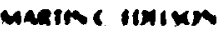

at coner

trims

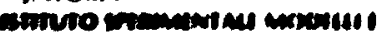

Minumise

c colla

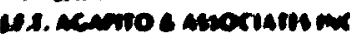

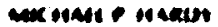

Mencringe mosith

1. mencerte

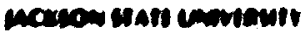

istes mintos

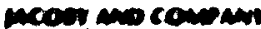

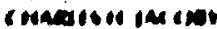

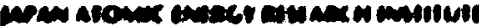
incise

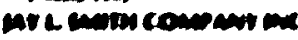

part inim

cecenomatron

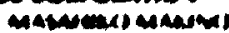

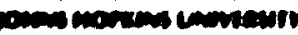

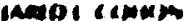

tromeno wi the

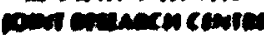

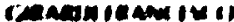

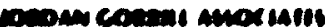

mincio itwa

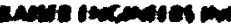

- iringm

it aite ian

cumanos coures

ename on in as

canse and on man in ant

Convicominger

edentin 4110 mansis siall chorock al unte

WIIINIII HIIHIIIS

ans

IARSA SIIY)

chiten matia assuriates

IRTi力 IIRI AIt

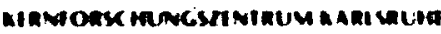
Gwas

a 111000

in sasi piviludit.

anoN associatis

HARR AllN

nome asmivit or inters ato

atsounces ante

(10)M.4 alv

eroto unmerets

voulla ing

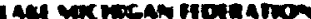

int cilitile

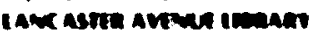

1 U C Mvantw

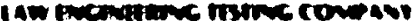
14064 12401

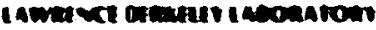

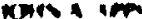

ineruatory

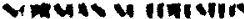

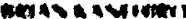

- Marum

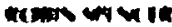

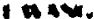

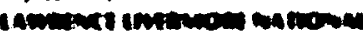

incintrom

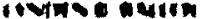

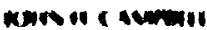

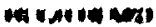

raserromer and $n$

it is inate

- A04 10 1010

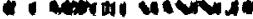

- er y t mare

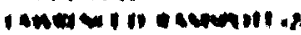

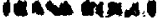

A 16 vite Iorio

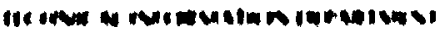
1. 10

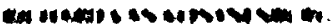

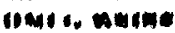

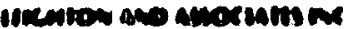

was of ot af.

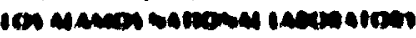

Itomate and the

cemel anesit

urind a inter

a cami

mase alow

uspe incerse

it an on undera

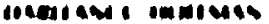

- 1 tratser

Inimete iscands

- * nor

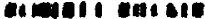

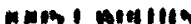

ir i nimivest.

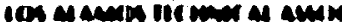

onitiol adition

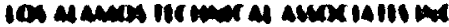

ism som at

ian ancests mect 1 enatca

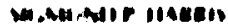

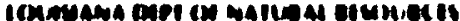

- Hatem notito

tonate nationatis

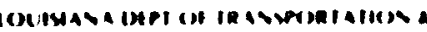
entilopuet

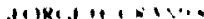

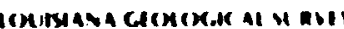

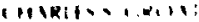

illitilig:

H11 11 -

conTryata covinums Giks

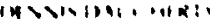

corryata weclian ingci cmisuon

I Hatl mallise.tie:

condust state towinuts

Rever : ; inlue

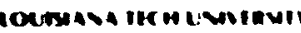

inR in,

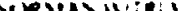

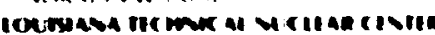
- "riningun

cosestron wowat mos a arigan vendi । 14 , ve

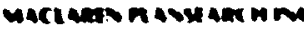

niln an!

mane remoric a vime

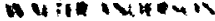

masermats astrong o.

nrmomos

n. man.

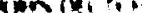

troventyin

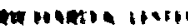

wincisitive

urastia uneservir

in watm?

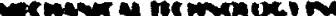

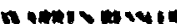

Itrob in inin

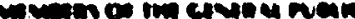

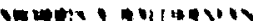

ormona

revisonet.

coven int.

ivens on vines

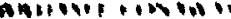

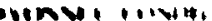

Atollo. 1109

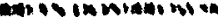

wWwhtl it in ine

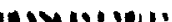

In thention til

at BDent

eteve entowis

comerobo bett

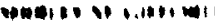

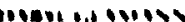

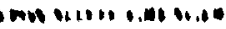

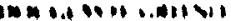

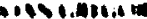

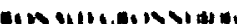

at+1116.1 4 ,

- lesan

init somes

meanill itser

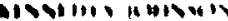

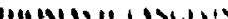

11. ind..111

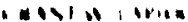

118014, hil

$11041,12 \cdot 12$,

111111111

n11 Ne in mis

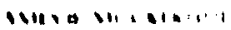

llterwiesto

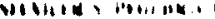


RCX,1QI minIR

WARIISRAIIIKI

I IRIS RH H

pal I vilnsen

and

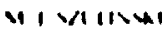

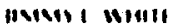

allavevis I Remes"

mochati eaxen, in inx

1 I 10x+411

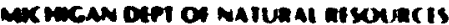

R IIKIMAS WR,All

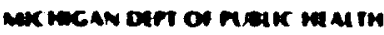

(x) I ADIARTMI

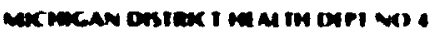

IIM. AR a Rill

vex recan crotock al semws

Risints ailis

mecrucan cominnous orisci

nilliave inilor

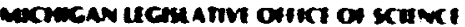
acowson

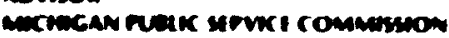
acos arits

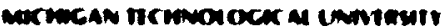

CANet in mint

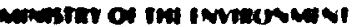

IAah bivel aw!

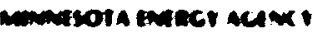

wal winati

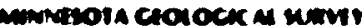

Mall s W allo

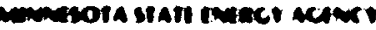

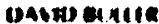

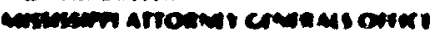

wac a I Amethos

crimineriav on cionoce

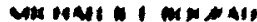

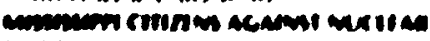

cuncese

M 4401 19 44 1101

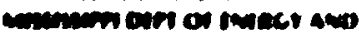

Pacenconation

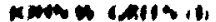

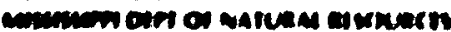

averat anse at

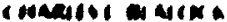

cusinn werest

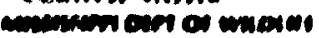

comerevation

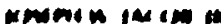

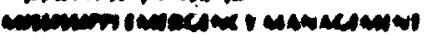

Acerist

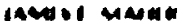

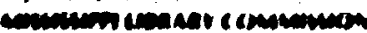

bala II:A

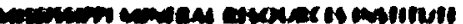

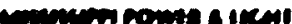

crimial weration

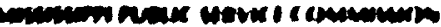

c cestor of onil

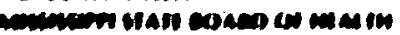

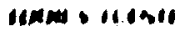

incerion oster

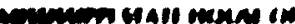

chemensicios

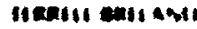

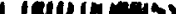

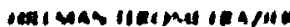

aner emiliti

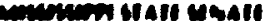

wallin I melit

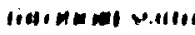

Mitat cone

IIVIR A IIUINAR

mosat reank al comp

AIDIII" HA HIISIII)

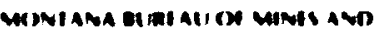

cainots

I I TRIAI

vasa nunasem sace civile

bill illi g initie!

mathonal acadivion sencis

ruis I Ingirmat

miln sures

vatronal athonactics amo seace

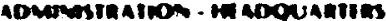

meit ur a c coveteis

-atromar arowar vareua

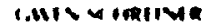

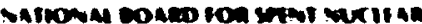

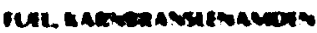

DHCKOMB

Manomal cumbug stangatos

linket cestavins

unitave atil

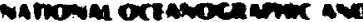

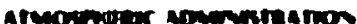

140 a on in to

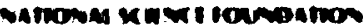

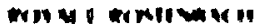

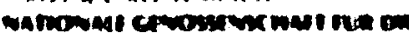

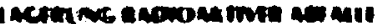

watater to

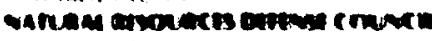

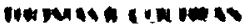

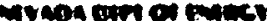

cotat in

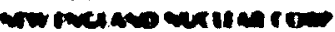

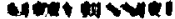

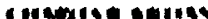

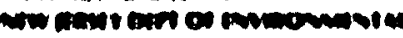
merine ber

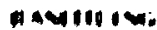

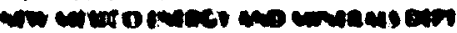

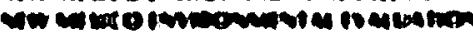

cense

crimen in wint

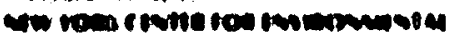

meominusin

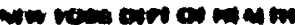

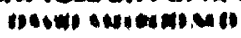

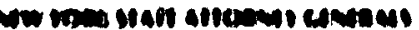

cavin:

imeir or a

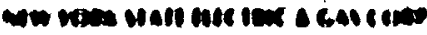

tomars und

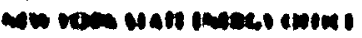

torto to teles it

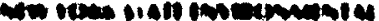

carmatint ceres

aw atil i wames

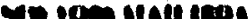

inat in tom

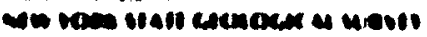

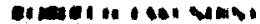

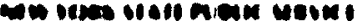

canciencin

cotioste te.

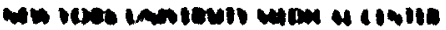

curea in a 10

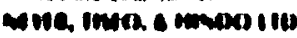

at indal

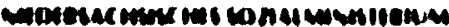

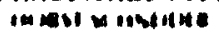

MORIM C AROMINA DAPI (N vatuRat

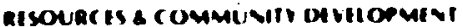

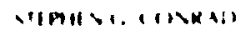

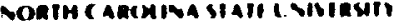

De alvintmil,

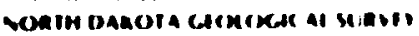

IxNI Holliton.

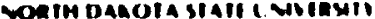

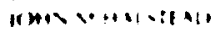

womint ast buna countr arcional

natwre a detflopmist oncawialion

it 4 +s, pilan,

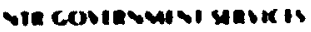

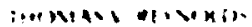

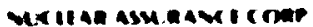

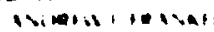

anes ene vild

erenvil ville

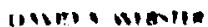

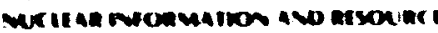
savke

invorami:

wetian saren associates ne

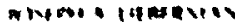

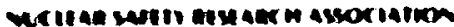

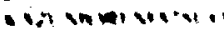

meiten wast watrom

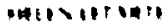

wis rome

n...

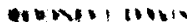

nmenting ind

evenov vill

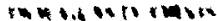

rimainnentiven

atection

1 nut

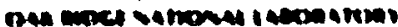

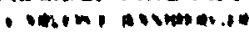

il cormer.

W 11 vin mo

4k10. on

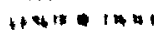

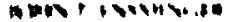

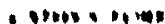

100401 ain 140

1 Mtria

mon ontipe.

1. " . "1 ve

itrents , Ilim

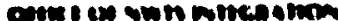

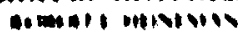

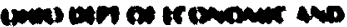

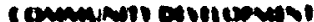

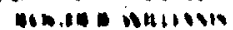

ama ores or enect

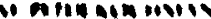

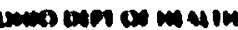

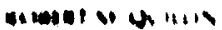

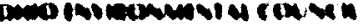

itent on otili

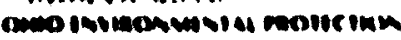
acines

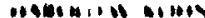

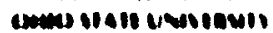

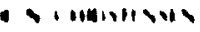

1 comina

1) $11+140$

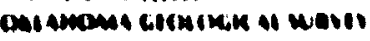

inteilet lints

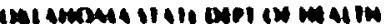
*..

\section{8}


cminer) menc)

K I HIKSI

1 111

(RAll. I VNIPM

Oonnininin

mitrI MSIIt

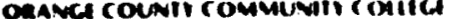

I Anat $\mathrm{C}$ ! ( I Heil)

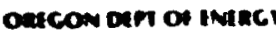

IM NAII) IS (A HIARI

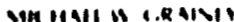

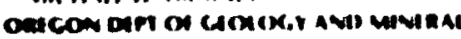

mousterts

orconsian unatasir

Bais (X 1 1 M)

c. Caindi

Cocevitation fon ecomomax

coomation and diviomatel

I P cinur

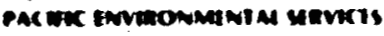
aniat al ?

pacarir cas and Hicter roment

Rarvound on

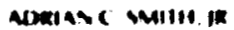

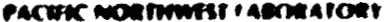

Exint BenMI

nc molnmina

1 I I a a ka

Guito ( 1 mil

satevitixn!

onva11 I In:

I 11 lakel It

mate antilla

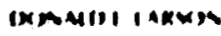

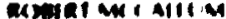

a Whilam witho

11 valinen

I M nivis

Q Hit neta

I. Nalum

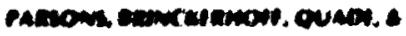
coveratem max

I arani

neresence

tow to in PA:

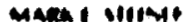

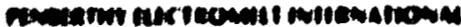

cons.

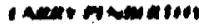

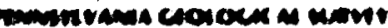

ariva a varion

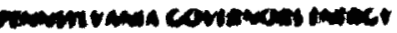

councr.

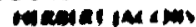

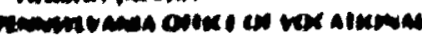
cinamanam

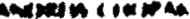

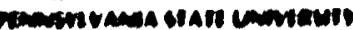

naviana A Hite

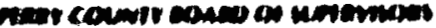

- are a nuavilion.

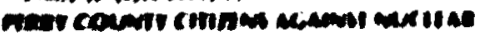

vinar enjerm

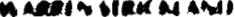

nitot rallt:

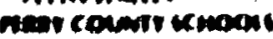

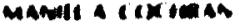

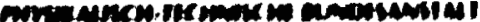

Gile canowe al

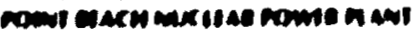

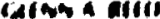

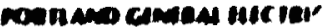

in 119ivis

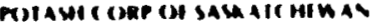

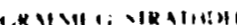

nilonar comalinir ations conch:

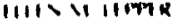

romin AUImonir of ImI SIAII OA vin

rom

WRGW II A II MARM

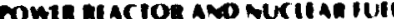

uniomani componation

mescen mi c overimouse

rapurtion INAMtasils

mile sing ind

1. 1 ming

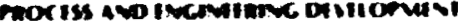

idraIII RIIIIR

Max ing umiths chove

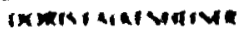

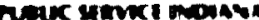

comer s Wist

croce unmethit

pil Sillow two

cunomincons

incrivi elvers

te ecomentiants be

mint inNm

Mabiser cona

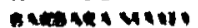

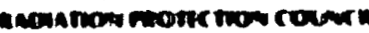

IInI Inerva

asmer

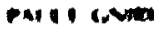

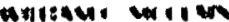

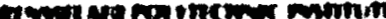

14costo

motron ent has

Harkn

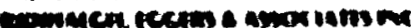

wathe inalle

cremeal mances oninations

consty char

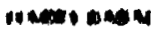

D. ontrat

- tont

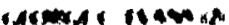

1 inten

* Intate

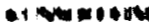

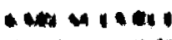

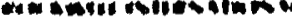

- lonima ana

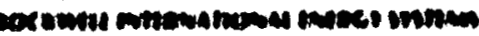
conse

a inati

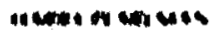

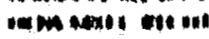

1 then wa 11 mallo

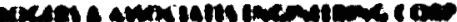

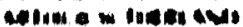

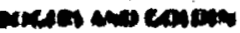

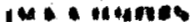

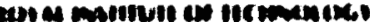

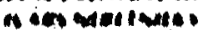

Niter.

inent

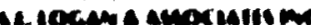

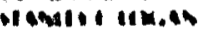

cu. shander ram

cimat in a

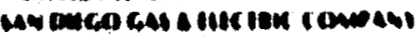

itrenatentill

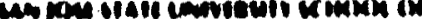
tercmestomis

a Anemin

80040 iastanater

R+?'?

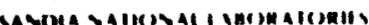

1. 1 $1,:+$

$\because+1, n+\infty$

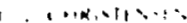

$\therefore 4110,1,14$

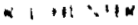

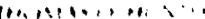

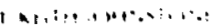

incien

a ind

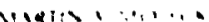

nen

ise?

1. 1 in 40

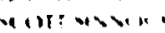

- Nivile

if erometare

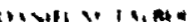

WD, Wilt

nition in

310001000.860

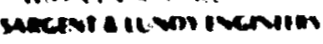

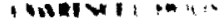

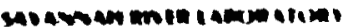

ip inti:

- venteris

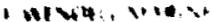

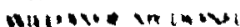

- nimine in

innulinimit.

in

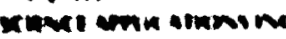

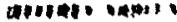

cention

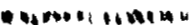

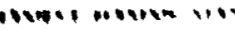

innobin why

10.1 1

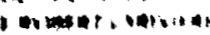

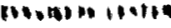

mite! unisenter

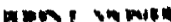

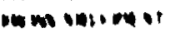

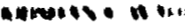

chate 11 iा 14

un ment vin w

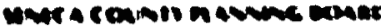

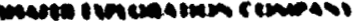

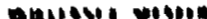

manmone wnoten in

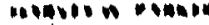

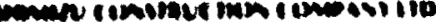

in ivin inen.

chane clue

lin in ints

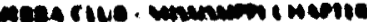

mese chuprom the

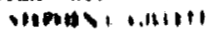

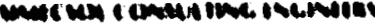

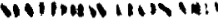

ul. coumis couvenumber

cetionatich

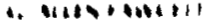

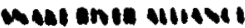

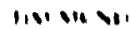

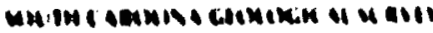

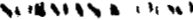

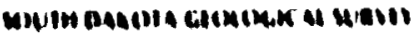
Q11 +1941, ant1:

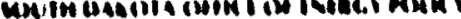

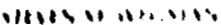

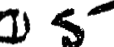




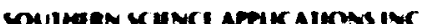
a "AIRH

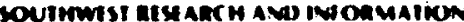
ctivita

ixNindix,

NIVNP IM NRE

S conaventuat vaviasis

( ARI I In ARIX.

s) rostern counted

citint Markitim

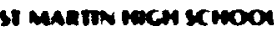

RAISTNII WIRIIT)

STAMTOCD UMmESTI

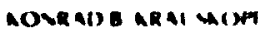

inniv $R($ Mu)

state of meas, aAOAation aDmsont

conero

IAlRAallitr

siati cumbitry on Mw rom at

encesamton

inavist ni

stians-octe cremcts the

viku ix ett?

socen 6 mestre encienteonc robs

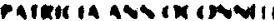

ince

4 ront

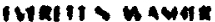

stress ovancice e Amoriates the III): Min GNAM

snowo chorock o romal

a Maniom A4a

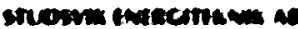

and invicest

eque warsm

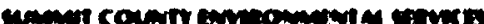

ianas 1 chent:

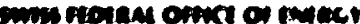

c merate

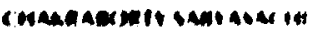

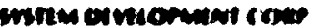

ax Marts Gavare

o. Inave

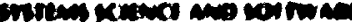

nivinatas

1ar calis me

Iothis colle

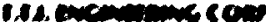

ixmance rimata

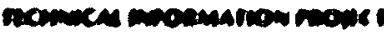
(x)maneat

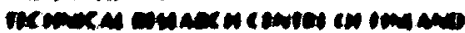

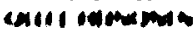

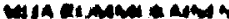

cantara

vero vech

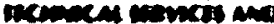

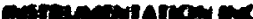

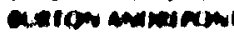

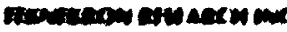

anltento ame all

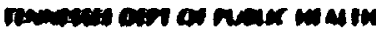

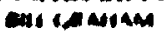

mescenct

taverue to und 401

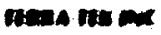

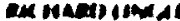

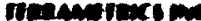

monacte (Miles)

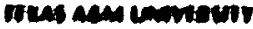

How Machan

criv want is

sabt wariari
CART ROBRE

1A311 सI जU11

It ias eunt aU or anomation comiteo

IXINAII), AVIXRYX

It has orpt on mathe

1) HIII L I AC AL

thas tmangt a vaturat misovinces

covrsom cownca

IreRI A IRRCO

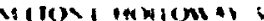

aren aim.

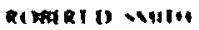

resas cuet ma

11. ic ix.

reas siati minastorame

MII 14\%

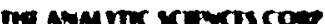

nent a sentitit

citimis y inta

ow riman crove?

a $4 \times 1 \times$

Hin Crnomist:

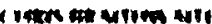

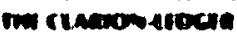

vaten watation

monity Acocratis

(I Antwo a

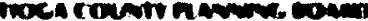

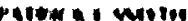

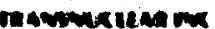

Bit a orit

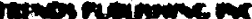

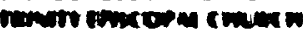

entavite cart

ther the

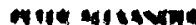

1 i comonom

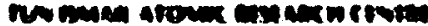

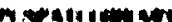

no nowia cermen

stom ichunats

(1)

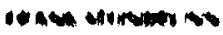

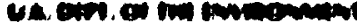

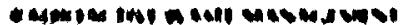
Inveatem

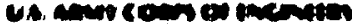

in menters

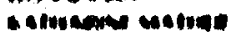

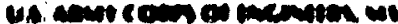

Gorave crepert

anem emasa,

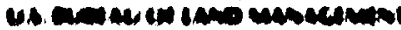

ctwa row on

cren mis

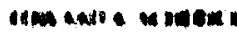

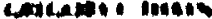

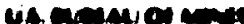

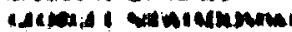

us crupes extacestum

ried it win

ve bin a cammet

wite a on mo

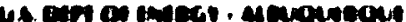

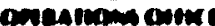

- cimie.

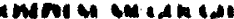

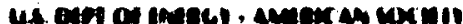

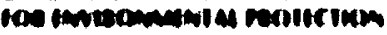

e expresotion

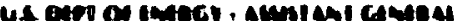

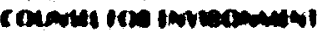

il tafthilu,il

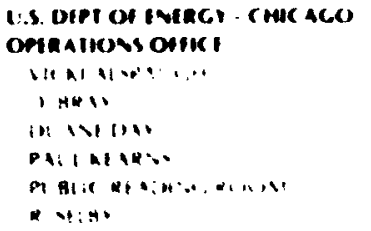

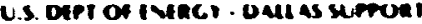
orike

(IRIIN) IR, MU In

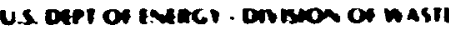
etroston Defrorkt ol

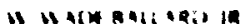

is wevit

- comati:

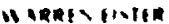

vith in int

(nit) reterend

IRivaliviverar.

lennespetemes

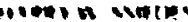

res comb

- 4nevist

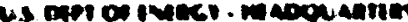

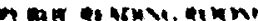

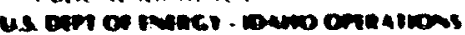
orms

ingere.

cover irengers

con encateron

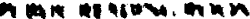

on $\cos$

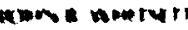

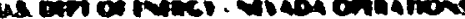
come

- enetrit

W* ar wo

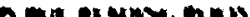

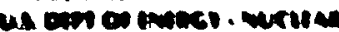

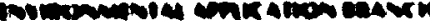

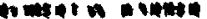

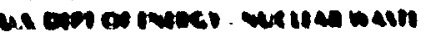

that rats wow w

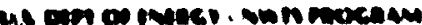
covir:

Pontat

yo ine mont?

10140

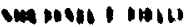

- tomit

- iniliar

in ail!

40

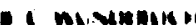

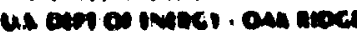
Onentions curke

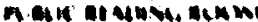

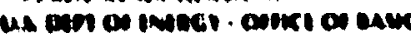
onction crindest

vethe $n$ milltis

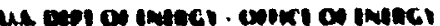
ascianc $M$

in tha I Himeth

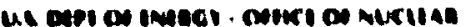
ves coces

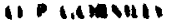

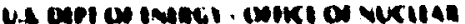
nati natachest

itritsitsis

ena in linge! 


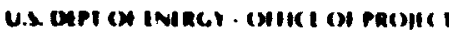
AMD IAC RIIHS MANACIMENI

1) I HARINAT

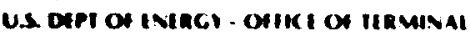
wasti dasnosa

IRAVAIIST 1 (111)IS

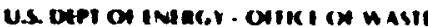
Gouation

INPI IIIK)

IAvit vistits

us ofm on enater - oniki on waslt Frooucts

C. A OARIII

IAMt II.RI

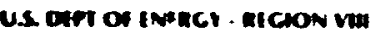

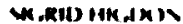

us oter os emact - axmann

criations ovek

R Cantaris

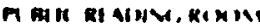

1 renima

0 I witkis

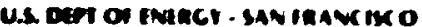

omenations ownce

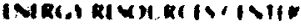

F.erk RI AIAW. Roxim

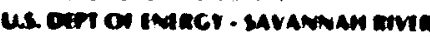
oninamons ortuce

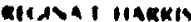

ic invimat

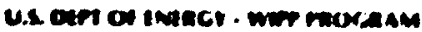

IAnkt $x+11$ 164k the

UA Din OH LACOO

Mit 6 Ylltit

atis $n 1$

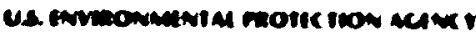

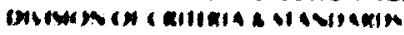
Gowals in atte

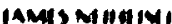

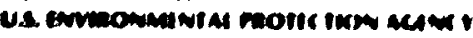
- arcion

corro illimas

us cenina ar counture oners whoram (Javils and whe

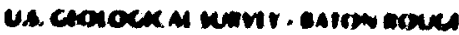

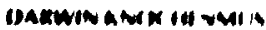

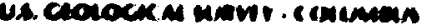

A M IA WNA H

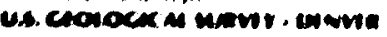

nurer it enatil

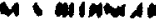

ats a clititisus

C. Interion

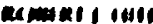

w cortente

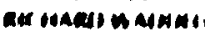

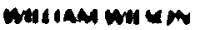

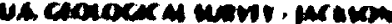

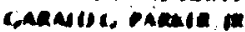

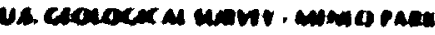
GMen antinoknos

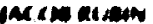

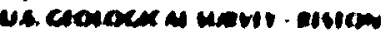
crmav ariminim

ismerar masiana

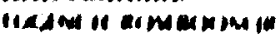

Mile allows

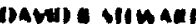

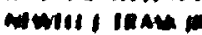

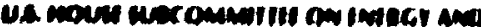

aiv Gavingumes

manes a taks

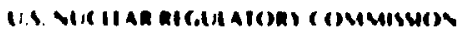

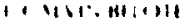

R HOMI

mikid I I INII!

Denthentis

(111 11911, a: 16, at, ew:

11301

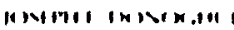

I I IM WII

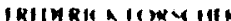

RH IIRI) HONIT

PAI I I.ABIRIR.

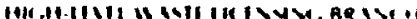

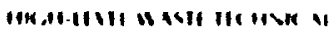

RCARRI MNINGD

GIIM N PIte

moition is ors

IMU11, AI IRU.

to IItIR!

livine Home

I Ina 4a:

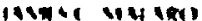

KWIV vinits.

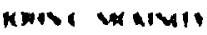

In wint velle

IINMANI Whater

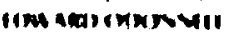

a * wo th thene

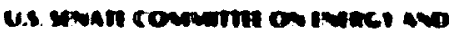

vatcan atounch

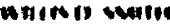

U.W. - romerita same

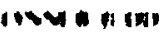

Cnime crimit

ImIVAa

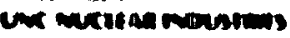

110 minitis

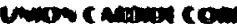

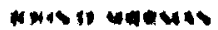

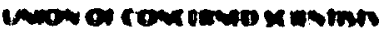

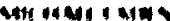

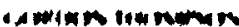

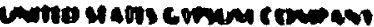

11 cM MAlti

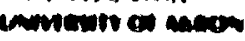

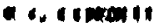

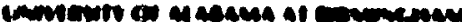

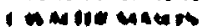

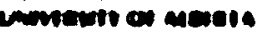

1* *an and

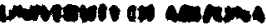

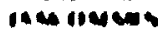

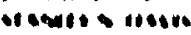

1904. 10.

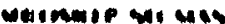

axos. nnil

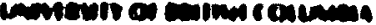

- Miserietir

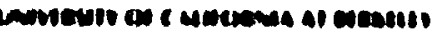

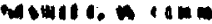

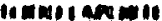

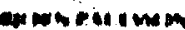

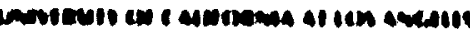
indiat

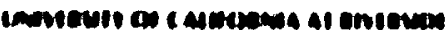

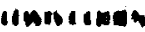

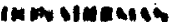

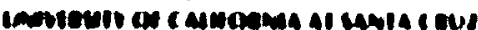

Ami misur.

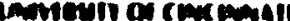

11111 a ali ine

canteris on mist it

cratele matist

ceome or it

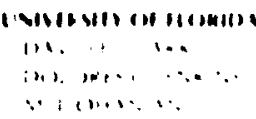

(M)

111.. 1..

(i) ),

$\because$ i $\{1, \ldots . \cdots$

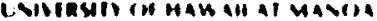

1,1. $1, \ldots$

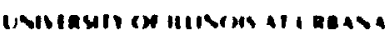

(MAMPAK.

III): , . I .

Ink: $1 . . .$.

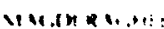

WMIasti of IOnIII

intin ...4.

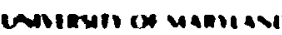

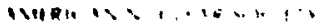

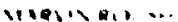

indents on unvers

11. . 1 19:4:.

confersto of carsusum

peme1, : 140

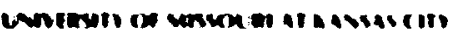

tintiv 1, at at

netre $\cdots \cdots$

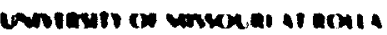

uts

ceristo. Me

Din a tua in:

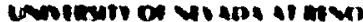

none't llike

min wirke

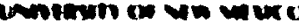

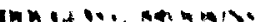

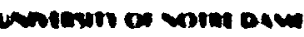

nom in is

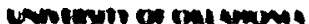

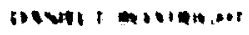

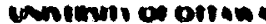

it witivis:

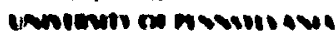

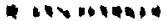

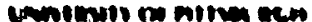

1 1 1

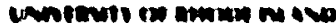

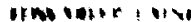

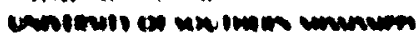

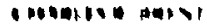

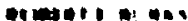

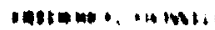

nowon miven

11001 "val

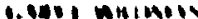

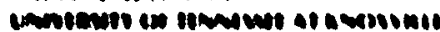
10 in ivit

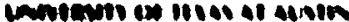

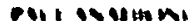

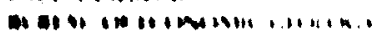

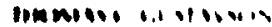

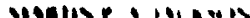

towi bits

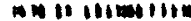

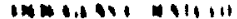

1. Mien

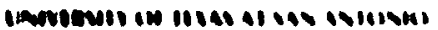

14 W $111+411011$

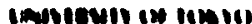

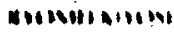

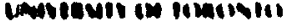

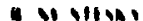

Jass tewts in UIAM

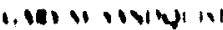

velum in wis

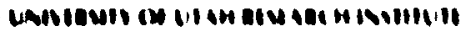

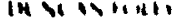

min Ixin 
Imwasulv of washancion.

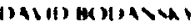

av 1111

II Romais

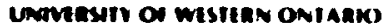

willasts 1111

unmosutr of meromen

D. Hainus

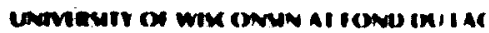
Mniv $n$ is 11

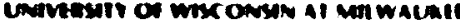

INUW ARI) PV(1:

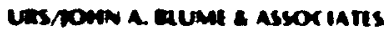

erconates

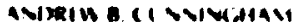

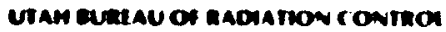

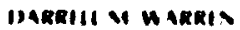

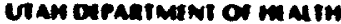

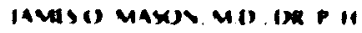

vian crolocaca aro cumbena uavt

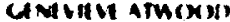

Gace romita:

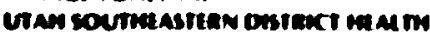

oconarmant

Rostat ILRism

van stan entrinstr

ixet in calsex,

unutr data matrtute

ints vont

varotand croveraty

in ate te pakte

vinco

$0<$ vonim.

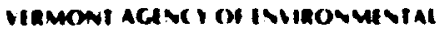

Conseratron

I1AkIIS Ralll

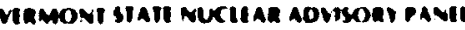

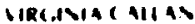

vincima otPt Oe matim

NOARI C. WKRIIV

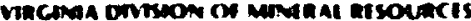

Rinater linn:

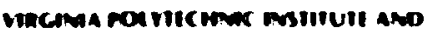

siati Unmensty

A A tIR MABA 4RT

Datid n nuts

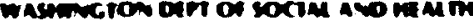
situres

I socow.

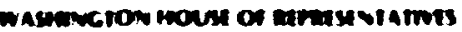

ar exan 4n

wasimicton stant unverist

cactuat il at

watmas

cost nat1

wama gat undinim

lawas aroming

menter

a viano itarom

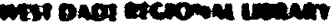

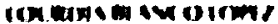

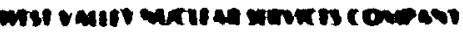

$m$

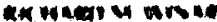

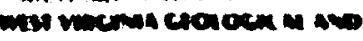

remonat sums

nouner reving

\section{wistincenouse flictarc conp \\ iroti a hiz: \\ i) VIWA? \\ chescetp and \\ 1411011 - 4,1) \\ nistruchouse wire moner}

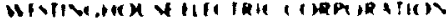

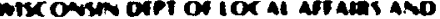
orvilomater

(1)

wesconsen on

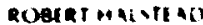

wiscowan crotock al and varuen mstomi semetr

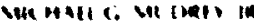

verenter oninem

wrsc onsen nuak stroke com

me incmina

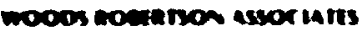

noodenaloucivel conveliann

- cennill :

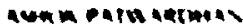

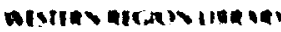

mostrive a

in shitions

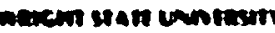

- ina

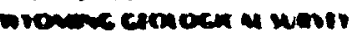

istwat staila

vell combingro

moto und 


$$
\frac{1}{n}
$$

